ESCOLA POLITÉCNICA DA UNIVERSIDADE DE SÃO PAULO

Departamento de Engenharia de Construção Civil - PCC

MICHELLI GARRIDO SILVESTRE

INFLUÊNCIA DOS SISTEMAS CONSTRUTIVOS NAS

MODIFICAÇÕES PROMOVIDAS PELO USUÁRIO

EM UNIDADES DE HIS: ESTUDOS DE CASO

NA REGIÃO DO VALE DO PARAÍBA/SP 
MICHELLI GARRIDO SILVESTRE

\section{INFLUÊNCIA DOS SISTEMAS CONSTRUTIVOS NAS MODIFICAÇÕES PROMOVIDAS PELO USUÁRIO EM UNIDADES DE HIS: ESTUDOS DE CASO NA REGIÃO DO VALE DO PARAÍBA/SP}

Dissertação apresentada à Escola Politécnica da Universidade de São Paulo para obtenção do título de Mestre em Ciências. 
MICHELLI GARRIDO SILVESTRE

\title{
INFLUÊNCIA DOS SISTEMAS CONSTRUTIVOS NAS MODIFICAÇÕES PROMOVIDAS PELO USUÁRIO EM UNIDADES DE HIS: ESTUDOS DE CASO NA REGIÃO DO VALE DO PARAÍBA/ SP
}

\author{
Dissertação apresentada à Escola \\ Politécnica da Universidade de São Paulo \\ para obtenção do título de Mestre em \\ Ciências. \\ Área de concentração: \\ Engenharia de Construção Civil e Urbana \\ Orientador: \\ Prof. Dr. Luiz Reynaldo de Azevedo Cardoso
}




\section{FICHA CATALOGRÁFICA}

\section{Silvestre, Michelli Garrido}

Influência dos sistemas construtivos nas modificações promovidas pelo usuário em unidades de HIS: estudos de caso na região do Vale do Paraíba/ SP / M.G. Silvestre. -- São Paulo, 2013.

$259 \mathrm{p}$.

Dissertação (Mestrado) - Escola Politécnica da Universidade de São Paulo. Departamento de Engenharia de Construção Civil.

1.Habitação popular 2.Sistemas e processos construtivos 3.Avaliação de desempenho I.Universidade de São Paulo. Escola Politécnica. Departamento de Engenharia de Construção Civil II.t. 
A Clara, Maria do Socorro e Geoniza (in memoriam), as mulheres que me guiaram e me inspiraram a chegar até aqui. 


\section{AGRADECIMENTOS}

Ao Prof. Dr. Luiz Reynaldo de Azevedo Cardoso por aceitar o desafio de me orientar neste trabalho.

Ao Prof. Dr. Francisco Cardoso e ao Prof. Dr. Francisco Comaru pelas preciosas contribuições no exame de qualificação.

À Eng. Graciana Nascimento pelo incentivo e pela preciosa ajuda sem a qual este trabalho não teria sido realizado.

À Msc. Eng. Patrícia Mendes Silva por me atender prontamente e por me fornecer as informações necessárias e ao Eng. Heros José Vieira por abrir as portas da CDHU Regional Vale do Paraíba para a realização desta pesquisa.

Ao Arq. Tiago Ferrari e ao Arq. Carlos Chaves pelas informações prestadas e pela paciência em atender prontamente aos meus questionamentos.

Aos companheiros da $\mathrm{ABCP}$ - Associação Brasileira de Cimento Portland e à própria instituição pela oportunidade de realizar este trabalho, pelo incentivo, paciência e pelas valorosas contribuições.

À Prof. ${ }^{a}$ Miriam Gellert Paris, da Escola de Engenharia Mauá, a primeira a me mostrar como a engenharia civil pode contribuir para as questões urbanas.

À minha família e amigos pelo apoio e por entenderem a minha ausência nos últimos meses.

Ao Makao, pelos momentos de relaxamento, paz e alegria.

Aos meus irmãos, Mario e Marília, pelo apoio, incentivo e pela ajuda com as traduções e revisões durante esse período.

Aos meus pais, Clara e Mario, pela compreensão, paciência, pelo apoio incondicional e por me darem o suporte necessário para superar mais essa fase.

E a Deus, por colocar seres tão especiais em meu caminho, orientar minhas escolhas e guiar minha vida. 
Se não houver frutos, valeu a beleza das flores. Se não houver flores, valeu a sombra das folhas. Se não houver folhas, valeu a intenção da semente.

Autor desconhecido, citado por Henfil 


\section{RESUMO}

Nas últimas décadas, a qualidade dos empreendimentos de habitação de interesse social (EHIS) vem sendo muito discutida por pesquisadores brasileiros em virtude dos diversos problemas de ordem técnica e funcional relatados por seus moradores após a ocupação. Para identificar esses problemas e suas causas, utiliza-se de processos de avaliação pós-ocupação (APO), que têm mostrado, ao longo dos anos, a insatisfação dos moradores com diversos aspectos das construções e a consequente realização de modificações na casa, muitas vezes sem qualidade, comprometendo ainda mais o seu estado. Visando à melhoria da qualidade dessas modificações, é possível adotar alguns procedimentos. Entretanto, ainda há um grande desconhecimento dos profissionais em relação ao que ocorre no ambiente construído no decorrer do uso, sendo ainda necessário aprofundar os estudos nesse sentido. Assim, a pesquisa aqui apresentada tem como objetivo identificar as principais modificações realizadas pelos moradores de empreendimentos horizontais de HIS, suas causas e possíveis mecanismos para diminuir, controlar ou planejar essas alterações. Para o desenvolvimento do estudo proposto, foram realizadas pesquisas bibliográficas e avaliações pós-ocupação em três empreendimentos de HIS. Assim, analisando as experiências passadas e presentes, foi possível gerar conteúdo suficiente para embasar propostas de melhorias nos programas habitacionais voltados a HIS.

Palavras-chave: Habitação de interesse social. Sistemas construtivos. Avaliação pós-ocupação. 


\begin{abstract}
In recent decades, the quality of the housing projects of social interest has been largely discussed by Brazilian researchers due to several technical and functional matters reported by dwellers after occupation. To identify these problems and their causes, post-occupancy evaluation processes are applied, which have shown over the years, a lot of dissatisfaction with various aspects of constructions, resulting in house modifications, oftenly without quality, further compromising their state. In order to improve the quality of these changes, it is possible to adopt some procedures. However, there is still a great lack of knowhow from professionals about what happens in the built environment during its use, them, being still necessary to sharpen the studies in this direction. Thus, the post-occupancy evaluation research presented here aims at identifying the main changes made by the dwellers of horizontal housing enterprises, its causes and possible mechanisms to reduce, control or plan these changes. For the development of the proposed study literature research was conducted and post-occupancy evaluations was made in three housing enterprises. Thus, making an analysis of past and present experiences, it was possible to generate enough content to support proposals for improvements in housing programs.
\end{abstract}

Key words: Social Housing. Construction systems. Post-occupancy evaluation. 


\section{LISTA DE FIGURAS}

Figura 1 - Ciclo de execução das habitações incluindo a APO ..............................53

Figura 2 - Mapa de localização das cidades escolhidas ..................................... 77

Figura 3 - Vista da cidade de São Luiz do Paraitinga ........................................ 81

Figura 4 - Imóveis tombados pelo patrimônio histórico .......................................82

Figura 5 - Enchente atinge São Luiz do Paraitinga ....................................... 83

Figura 6 - Obras de reconstrução da Igreja Matriz e de casarão histórico ...............84

Figura 7 - Implantação do Conjunto Habitacional São Luiz do Paraitinga "C" ..........85

Figura 8 - Vista geral do Conjunto Habitacional São Luiz do Paraitinga "C" ............86

Figura 9 - Planta da tipologia TG33A modulada no sistema RBS .......................87

Figura 10 - Corte longitudinal da tipologia TG33A modulada no sistema RBS.........88

Figura 11 - Tipologia de fachada das casas em São Luiz do Paraitinga ..................88

Figura 12 - Estudo de cores para fachadas das unidades .................................89

Figura 13 - Fotos da execução das obras em São Luiz do Paraitinga ....................90

Figura 14 - Casa entregue em São Luiz do Paraitinga .....................................92

Figura 15 - Interior de uma das casas logo após a entrega ..............................92

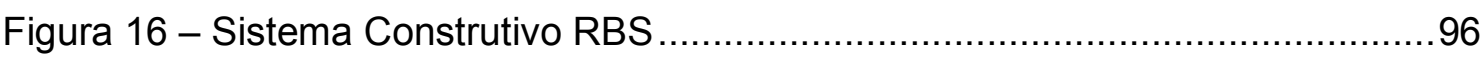

Figura 17 - Detalhamento dos painéis e conectores do sistema RBS ...................97

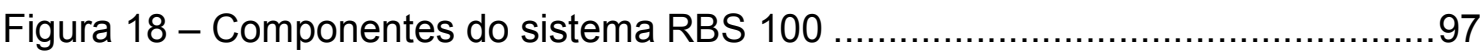

Figura 19 - Comparação de etapas entre os sistemas convencional e RBS ............98

Figura 20 - Perfis separados na obra para utilização no dia ................................100

Figura 21 - Execução do radier ............................................................... 100

Figura 22 - Marcação dos eixos de referência no radier ....................................101

Figura 23 - Montagem dos painéis de PVC ......................................... 101

Figura 24 - Serviço de embutimento das instalações nos painéis ........................102

Figura 25 - Vista dos painéis de PVC escorados ....................................... 102

Figura 26 - Etapas de concretagem do Sistema RBS ..................................103

Figura 27 - Concretagem dos painéis de PVC ainda escorados .........................104

Figura 28 - Concretagem da laje pré-moldada ............................................ 104

Figura 29 - Montagem da estrutura da cobertura ........................................... 105

Figura 30 - Piso cerâmico recém-aplicado ................................................ 105 


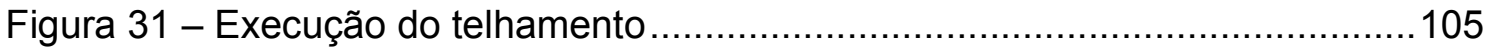

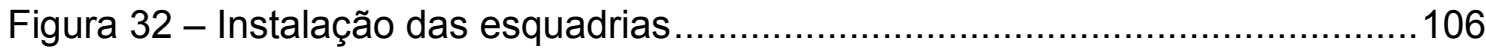

Figura 33 - Exemplos de muros e portões executados pelos moradores ...............117

Figura 34 - Trincas no muro de divisa da SLP02 ...............................................117

Figura 35 - Trecho do terreno da SLP10 que apresenta empoçamento de água...118

Figura 36 - Horta na SLP01 e gramado na SLP02 ….....................................118

Figura 37 - Trechos cimentados no quintal da SLP02 e da SLP08 …..................119

Figura 38 - Pisos aplicados nos quintais das casas SLP08 e SLP12 …................119

Figura 39 - Sinais de umidade no teto do banheiro da casa SLP02 ....................120

Figura 40 - Sinais de infiltração no teto e paredes do dormitório 1 da SLP06 .........120

Figura 41 - Cômodo e banheiro novos executados na SLP04 .............................121

Figura 42 - Cozinha nova construída na frente do lote da SLP07 ........................122

Figura 43 - Detalhe da nova residência executada no lote da casa SLP11 ...........122

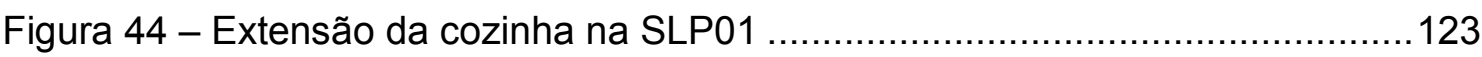

Figura 45 - Nova área de serviço e extensão da cozinha na SLP12 ….................123

Figura 46 - Fechamento da área de serviço nas casas SLP01, SLP10 e SLP12 .. 124

Figura 47 - Sistema de persiana e moldura de PVC danificados na SLP02 …....... 124

Figura 48 - Vista da cobertura da garagem da SLP01 ......................................125

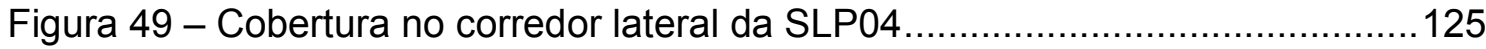

Figura 50 - Adesivos nas paredes e novo piso cerâmico na SLP01 ......................126

Figura 51 - Fiação da campainha danificada na SLP03 ……..............................126

Figura 52 - Vistas gerais das unidades assobradadas ..................................128

Figura 53 - Detalhe de ampliações realizadas nas unidades assobradadas ..........128

Figura 54 - a) Portal da cidade de Cunha; b) Vista geral da cidade de Cunha....... 130

Figura 55 - Parque Estadual da Serra do Mar - Divisão Cunha............................131

Figura 56 - Igreja Matriz Nossa Senhora da Conceição ......................................131

Figura 57 - Implantação do Conjunto Habitacional Cunha "B" ..............................133

Figura 58 - Vista geral do Conjunto Habitacional Cunha "B" ...................................134

Figura 59 - Vista geral do Conjunto Habitacional Cunha "B" ................................134

Figura 60 - Tipologia TG23A adaptada ao sistema construtivo ……………........135

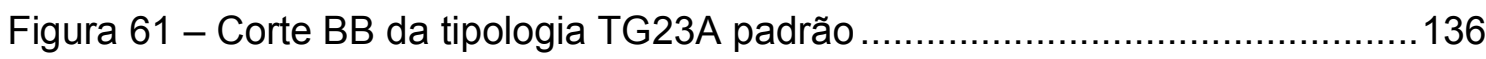

Figura 62 - Fotos da execução das obras em Cunha ...........................................137

Figura 63 - Casa entregue em Cunha .......................................................... 140 
Figura 64 - Interior de casa entregue em Cunha .............................................140

Figura 65 - Comparativo entre concreto convencional e concreto celular ...............141

Figura 66 - Execução dos radiers em Cunha ...................................................149

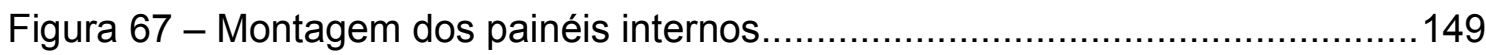

Figura 68 - Fixação das armaduras e elementos de esquadrias ..........................150

Figura 69 - Montagem das instalações ......................................................... 150

Figura 70 - Fechamento dos painéis de fôrmas ................................................151

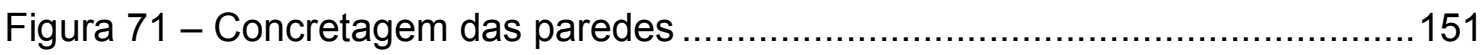

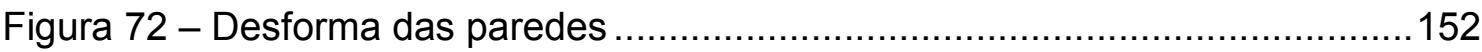

Figura 73 - Acabamento do concreto após a desforma ......................................152

Figura 74 - Preparação para execução dos oitões em alvenaria............................153

Figura 75 - Cobertura com estrutura de madeira e telhas cerâmicas .....................153

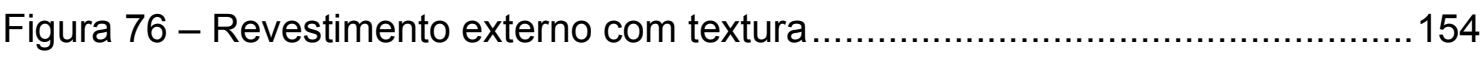

Figura 77 - Revestimento dos oitões com argamassa......................................154

Figura 78 - Exemplos de fachadas de casas com muros e portões .......................164

Figura 79 - Fachada da casa que executou apenas o muro .................................164

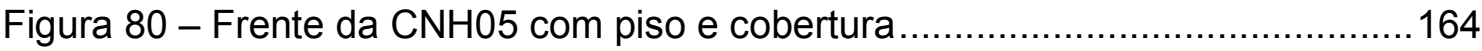

Figura 81 - Desbarrancamento do terreno nos fundos da CNH06 …....................165

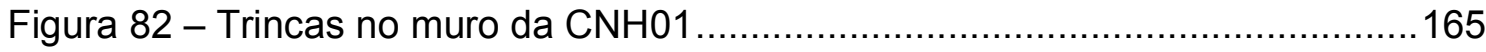

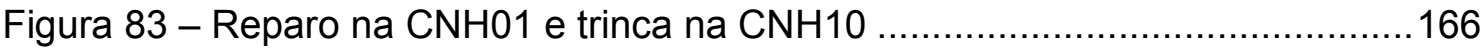

Figura 84 - Infiltração na CNH04 e reparo com rufo na CNH08 …........................166

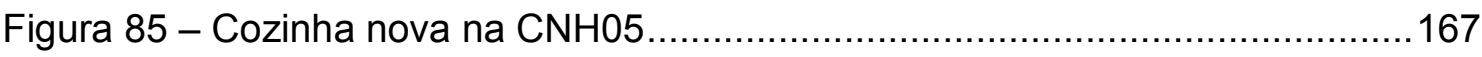

Figura 86 - Sinais de umidade na alvenaria da CNH09....................................167

Figura 87 - Infiltração na laje da cozinha nova da $\mathrm{CNH} 10$..................................168

Figura 88 - Balcão na CNH01 e muretas de alvenaria na CNH04 ........................168

Figura 89 - Trinca na ligação da parede nova com a antiga na CNH05 .................. 169

Figura 90 - Área de serviço da CNH04 e CNH07, respectivamente........................169

Figura 91 - Forro de madeira na CNH09 e de PVC na CNH07 ...........................170

Figura 92 - Área de serviço e varanda com forno a lenha na CNH09 ....................170

Figura 93 - Face externa de alvenarias sem revestimento na CNHO3 e CNH05.... 171

Figura 94 - Muro do corredor da CNH04 com infiltração ......................................172

Figura 95 - Vista aérea da cidade de Lagoinha ................................................173

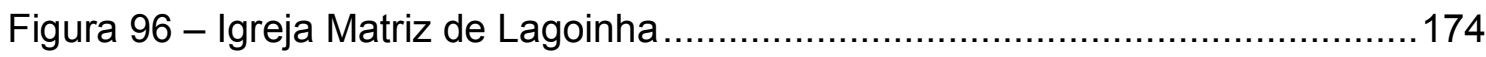




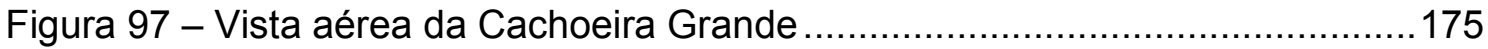

Figura 98 - Implantação do Conjunto Habitacional Lagoinha "A" ...........................176

Figura 99 - Vista geral do Conjunto Habitacional Lagoinha "A" ............................177

Figura 100 - Vista geral do Conjunto Habitacional Lagoinha "A" ..........................177

Figura 101 - Detalhe da tipologia TG23A na fase inicial com 2 dormitórios ...........178

Figura 102 - Tipologia TG23A em alvenaria estrutural, com 3 dormitórios .............179

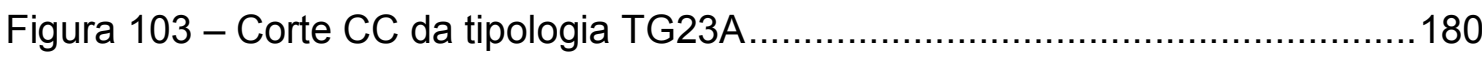

Figura 104 - Fotos da execução das obras em Lagoinha....................................180

Figura 105 - Casas nos três sistemas construtivos entregues em Lagoinha...........182

Figura 106 - Interior de uma das casas logo após a entrega ................................183

Figura 107 - Modulação utilizando a família 29 ..............................................193

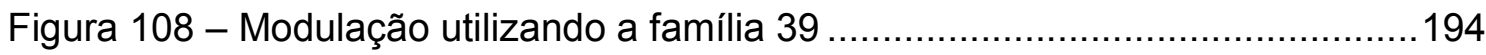

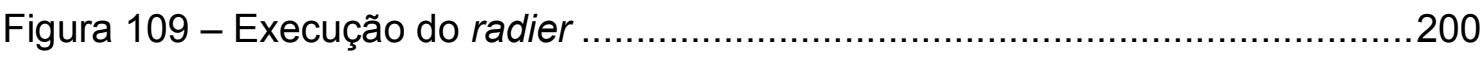

Figura 110 - Conferência das diagonais do pavimento …………....................200

Figura 111 - Marcação das paredes com o "cordex" ...........................................201

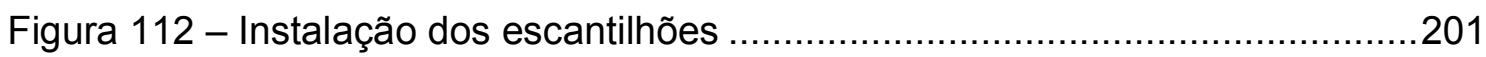

Figura 113 - Marcação das referências das fiadas ..............................................202

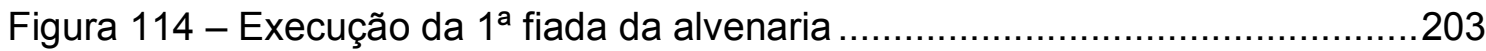

Figura 115 - Utilização de palheta e bisnaga na elevação da alvenaria ..................204

Figura 116 - Passagem de instalações no interior das alvenarias em Lagoinha ....204

Figura 117 - Grauteamento vertical da alvenaria.............................................205

Figura 118 - Laje maciça moldada in loco em casa de Lagoinha ..........................205

Figura 119 - Execução cobertura nas casas de Lagoinha....................................206

Figura 120 - Execução do revestimento das casas de Lagoinha ..........................206

Figura 121 - Vista de fachadas com muros e portões .......................................217

Figura 122 - Vista de fachadas só com portões ………………………….....217

Figura 123 - Lotes com trechos cimentados na LGN07 e LGN14 …...................217

Figura 124 - Trincas e afundamento no piso do quintal da LGN11 .....................218

Figura 125 - Detalhe de radier com empoçamento na LGN11 ….........................219

Figura 126 - Sinais de infiltração e trincas nas alvenarias da LGN01 ……............219

Figura 127 - Trinca horizontal e infiltração nas alvenarias da LGN06 …...............220

Figura 128 - Detalhes das falhas na superfície das lajes da LGN01 ....................220

Figura 129 - Detalhe de falhas em laje da LGN06 ...........................................221 
Figura 130 - Cozinha e dormitório executados na LGN01 ....................................221

Figura 131 - Cozinha com fechamento de madeira e telhas mistas na LGN03.....222

Figura 132 - Dormitório executado na LGN06, separado da casa original .............222

Figura 133 - Cozinha e dormitório em execução na LGN07 ..................................223

Figura 134 - Garagem e varanda executadas na LGN10 ................................223

Figura 135 - Sinais de infiltração na parede do dormitório da LGN11 ...................224

Figura 136 - Sinais de infiltração nas paredes da cozinha da LGN12 ....................224

Figura 137 - Sinais de infiltração na alvenaria da cozinha da LGN14 ...................225

Figura 138 - Reutilização da estrutura metálica da cobertura da LGN12 ...............225

Figura 139 - Telhas de fibrocimento na cobertura da área de serviço da LGN01 ..226

Figura 140 - Cobertura com telhas cerâmicas na garagem da LGN11 …..............226

Figura 141 - Porta de aço da LGN07com início de corrosão na base ....................227

Figura 142 - Banheiro da LGN01 com azulejos até o teto ...................................228

Figura 143 - Modificações típicas nas unidades da tipologia TG23A ....................233 


\section{LISTA DE GRÁFICOS}

Gráfico 1 - Estudo de Caso 1: Bens de consumo das famílias..............................108

Gráfico 2 - Estudo de Caso 1: Avaliação da casa recebida...................................109

Gráfico 3 - Estudo de Caso 1: Atendimento às necessidades..............................109

Gráfico 4 - Estudo de Caso 1: Problemas com umidade e infiltração......................110

Gráfico 5 - Estudo de Caso 1: Avaliação da iluminação .........................................110

Gráfico 6 - Estudo de Caso 1: Avaliação da ventilação ........................................110

Gráfico 7 - Estudo de Caso 1: Porcentagem de casas modificadas .......................111

Gráfico 8 - Estudo de Caso 1: Uso de projeto para realizar modificações ..............111

Gráfico 9 - Estudo de Caso 1: Agente realizador das modificações ......................112

Gráfico 10 - Estudo de Caso 1: Data da última modificação .................................112

Gráfico 11 - Estudo de Caso 1: Local de realização das modificações ...................112

Gráfico 12 - Estudo de Caso 1: Itens modificados.............................................113

Gráfico 13 - Estudo de Caso 1: Intenção de modificar o imóvel ..............................114

Gráfico 14 - Estudo de Caso 1: Urgência das modificações ................................114

Gráfico 15 - Estudo de Caso 1: Local que pretende modificar ..............................115

Gráfico 16 - Estudo de Caso 1: Serviço que pretende realizar ................................115

Gráfico 17 - Estudo de Caso 1: Benefício das modificações ................................116

Gráfico 18 - Estudo de Caso 1: Avaliação técnica da iluminação...........................127

Gráfico 19 - Estudo de Caso 1: Avaliação técnica da ventilação............................127

Gráfico 20 - Estudo de Caso 1: Avaliação das modificações realizadas .................127

Gráfico 21 - Estudo de Caso 2: Bens de consumo das famílias .............................156

Gráfico 22 - Estudo de Caso 2: Avaliação da casa recebida................................157

Gráfico 23 - Estudo de Caso 2: Problemas com umidade e infiltração....................157

Gráfico 24 - Estudo de Caso 2: Avaliação da iluminação ......................................158

Gráfico 25 - Estudo de Caso 2: Avaliação da ventilação .....................................158

Gráfico 26 - Estudo de Caso 2: Agente realizador das modificações .....................158

Gráfico 27 - Estudo de Caso 2: Data da última modificação .................................159

Gráfico 28 - Estudo de Caso 2: Local de realização das modificações ...................159

Gráfico 29 - Estudo de Caso 2: Itens modificados...............................................160

Gráfico 30 - Estudo de Caso 2: Dificuldades para realizar modificações ................160 
Gráfico 31 - Estudo de Caso 2: Intenção de modificar o imóvel .............................161

Gráfico 32 - Estudo de Caso 2: Urgência das modificações .................................161

Gráfico 33 - Estudo de Caso 2: Local que pretende modificar ..............................162

Gráfico 34 - Estudo de Caso 2: Serviços que pretende realizar .............................162

Gráfico 35 - Estudo de Caso 2: Benefício das modificações ................................163

Gráfico 36 - Estudo de Caso 2: Avaliação técnica da iluminação............................171

Gráfico 37 - Estudo de Caso 2: Avaliação técnica da ventilação............................171

Gráfico 38 - Estudo de Caso 2: Avaliação das modificações realizadas ................. 172

Gráfico 39 - Estudo de Caso 3: Bens de consumo das famílias ............................209

Gráfico 40 - Estudo de Caso 3: Avaliação da casa recebida..................................210

Gráfico 41 - Estudo de Caso 3: Problemas com umidade e infiltração....................210

Gráfico 42 - Estudo de Caso 3: Avaliação da iluminação .........................................211

Gráfico 43 - Estudo de Caso 3: Avaliação da ventilação ......................................211

Gráfico 44 - Estudo de Caso 3: Agente realizador das modificações .....................211

Gráfico 45 - Estudo de Caso 3: Data da última modificação ………....................212

Gráfico 46 - Estudo de Caso 3: Local de realização das modificações ...................212

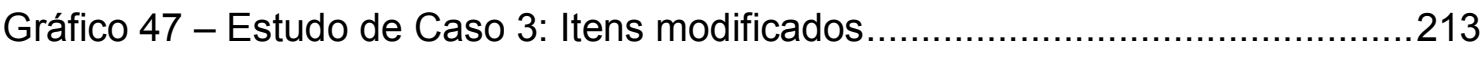

Gráfico 48 - Estudo de Caso 3: Dificuldades para realizar modificações ...............213

Gráfico 49 - Estudo de Caso 3: Intenção de modificar o imóvel ..............................214

Gráfico 50 - Estudo de Caso 3: Urgência das modificações .................................214

Gráfico 51 - Estudo de Caso 3: Locais que pretende modificar.............................215

Gráfico 52 - Estudo de Caso 3: Serviços que pretende realizar ...........................215

Gráfico 53 - Estudo de Caso 3: Benefício das modificações ..................................216

Gráfico 54 - Estudo de Caso 3: Avaliação técnica da iluminação............................226

Gráfico 55 - Estudo de Caso 3: Avaliação técnica da ventilação...........................226

Gráfico 56 - Estudo de Caso 3: Avaliação das modificações realizadas .................228 


\section{LISTA DE TABELAS}

Tabela 1 - Descrição das unidades do Conjunto São Luiz do Paraitinga "C" ...........91

Tabela 2 - Síntese da avaliação de satisfação realizada pela ONG InterAção.........93

Tabela 3 - Resumo do relatório de análise das anomalias nas casas de Cunha ...138

Tabela 4 - Descrição das unidades habitacionais do Conjunto Cunha "B" .............139

Tabela 5 - Descrição das unidades habitacionais do Conjunto Lagoinha "A".........182

Tabela 6 - Comparativo entre as famílias de blocos de concreto ..........................185

Tabela 7 - Famílias de blocos .......................................................... 186

Tabela 8 - Tipologias e prováveis causas de fissuras verticais ........................197

Tabela 9 - Tipologias e prováveis causas de fissuras inclinadas ........................197

Tabela 10 - Tipologias e prováveis causas de fissuras horizontais .....................198 


\section{LISTA DE SIGLAS}

$\mathrm{ABCP}$

ABNT

APO

$\mathrm{AU}$

$\mathrm{BNH}$

BPRU

CCMC

CDHU

CEF

COHAB

CONDEPHAAT

CREA

CSN

CSTB

CTE

EDRA

EHIS

FAU

FCP

FGTS

GEPA

HIS

IAP

$\mathrm{IBH}$

INOCOOP

IPT

NBR

NORIE
Associação Brasileira de Cimento Portland

Associação Brasileira de Normas Técnicas

Avaliação pós-ocupação

Avaliação de uso

Banco Nacional de Habitação

Building Performance Research Unit

Canadian Construction Materials Centre

Companhia de Desenvolvimento Habitacional e Urbano do Estado de São Paulo

Caixa Econômica Federal

Companhias de Habitação

Conselho de Defesa do Patrimônio Histórico, Arqueológico, Artístico e Turístico

Conselho Regional de Engenharia e Agronomia

Companhia Siderúrgica Nacional

Centre Scientifique et Technique du Bâtiment

Centro de Tecnologia de Edificações

Environmental Design Research Association

Empreendimentos de habitação de interesse social

Faculdade de Arquitetura e Urbanismo

Fundação da Casa Popular

Fundo de Garantia por Tempo de Serviço

Grupo de Estudos Pessoa-Ambiente

Habitação de interesse social

Institutos de Aposentadoria e Pensão

Instituto Brasileiro de Habitação

Institutos de Orientação a Cooperativas Habitacionais

Instituto de Pesquisas Tecnológicas

Norma Brasileira

Núcleo Orientado para a Inovação da Edificação 
NUTAU

$\mathrm{PAH}$

PIB

PLANHAB

PVC

RAC

RBS

SBPE

SFH

SINAT
Núcleo de Pesquisa em Tecnologia da Arquitetura e Urbanismo Plano de Assistência Habitacional

Produto Interno Bruto

Plano de Habitação do Governo Federal

Policloreto de polivinila, cloreto de vinila ou policloreto de vinil

Relações Ambiente \& Comportamento

Royal Building Systems

Sistema Brasileiro de Poupança e Empréstimo

Sistema Financeiro da Habitação

Sistema Nacional de Aprovações Técnicas 


\section{SUMÁRIO}

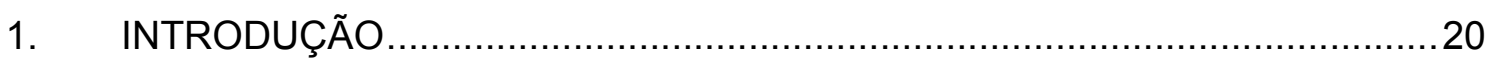

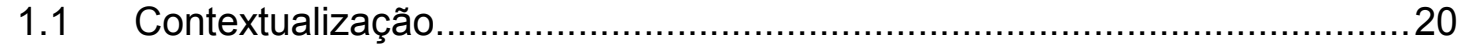

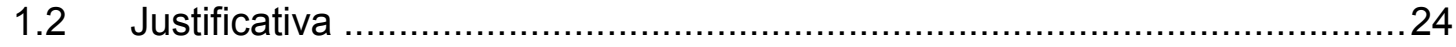

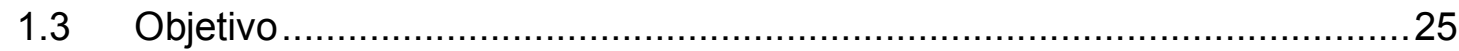

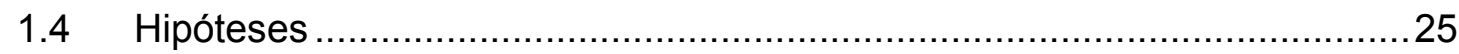

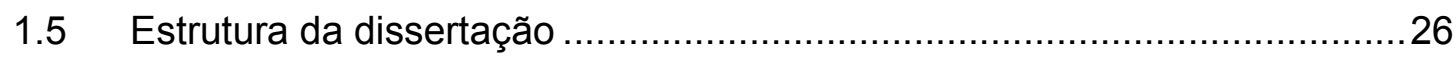

2. HABITAÇÃO E UTILIZAÇÃO DE SISTEMAS CONSTRUTIVOS NO

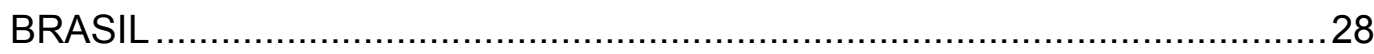

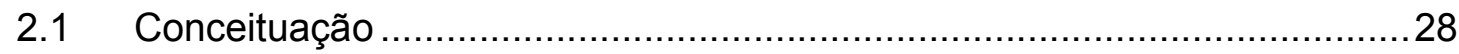

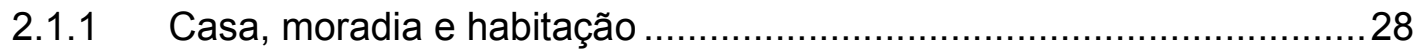

2.1.2 Técnicas, métodos, processos e sistemas construtivos ....................29

2.1.3 Racionalização, industrialização e inovação tecnológica......................30

2.2 A habitação no Brasil a partir do final do século XIX..................................32

2.2.1 Políticas Habitacionais das últimas décadas no Estado de São Paulo 39

2.3 A etapa de projeto na construção civil .................................................... 41

2.4 Adoção de sistemas construtivos inovadores ............................................ 43

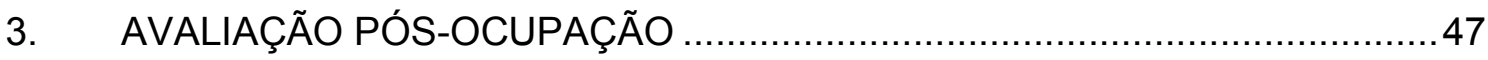

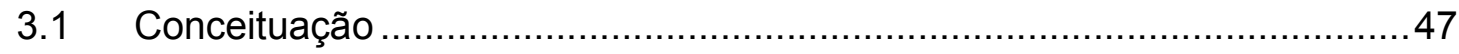

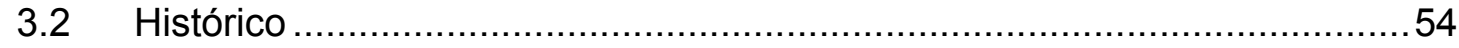

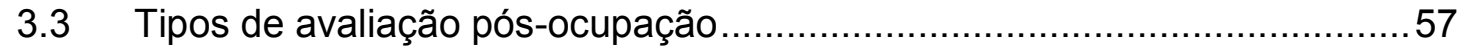

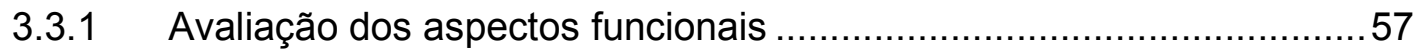

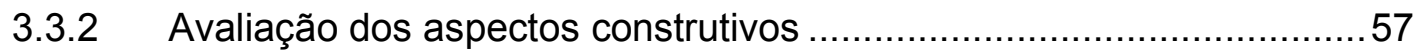

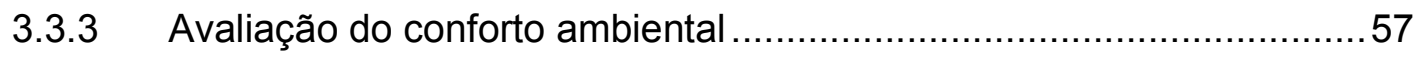

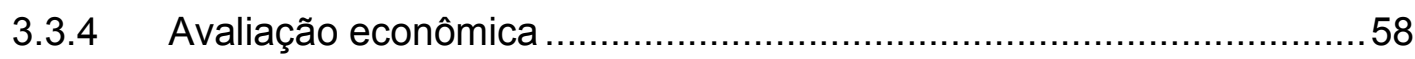

3.4 Métodos e técnicas de avaliação pós-ocupação.......................................58

4. MODIFICAÇÕES REALIZADAS PELOS MORADORES EM UNIDADES

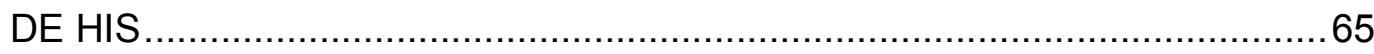

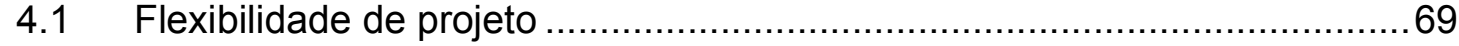

4.2 Assistência técnica para melhoria habitacional............................................73

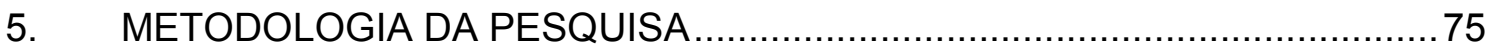




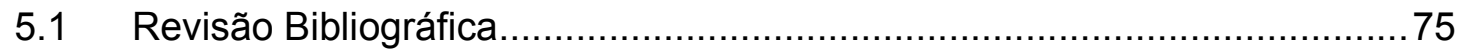

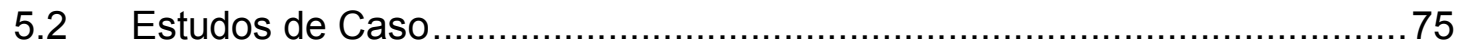

5.2.1 Definição da região e empreendimentos estudados .............................75

5.2.2 Preparação e Realização da Pesquisa de Campo................................77

5.3 Análise e Considerações .....................................................................

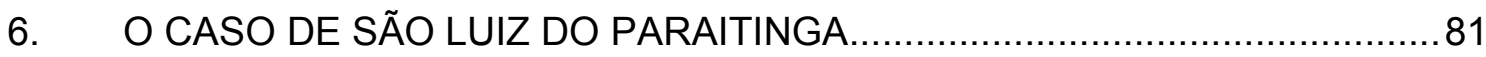

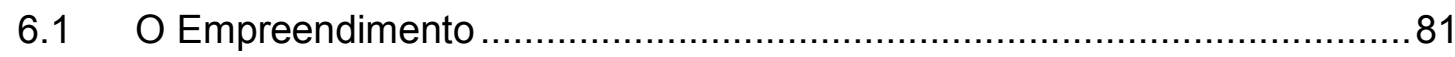

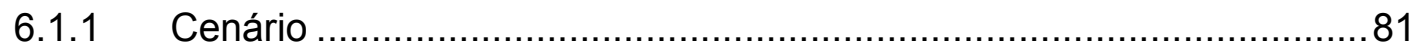

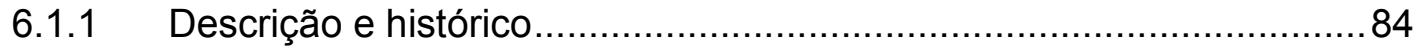

6.1.2 Sistema Construtivo: Concreto PVC - Royal Building Systems (RBS).93

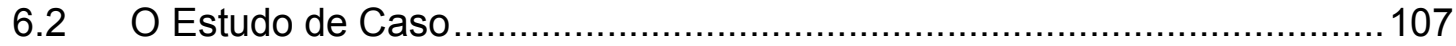

6.2.1 Apresentação e Análise dos Resultados das Entrevistas .................. 108

6.2.1 Apresentação e Análise dos Resultados da Avaliação Técnica ........116

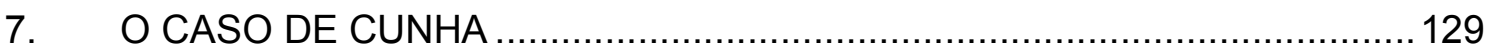

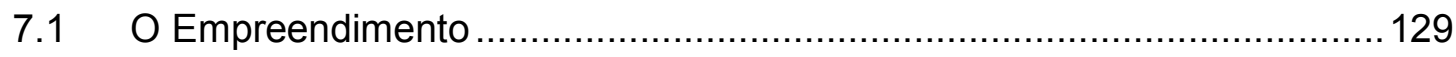

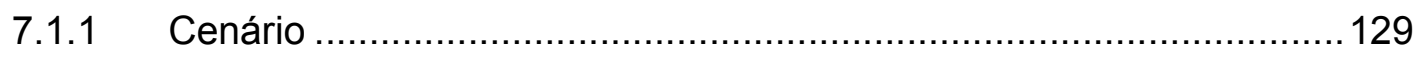

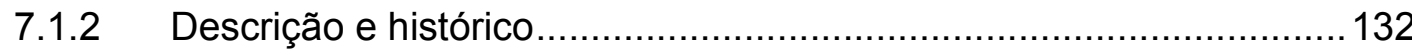

7.1.3 Sistema Construtivo: paredes de concreto celular moldadas in loco. 140

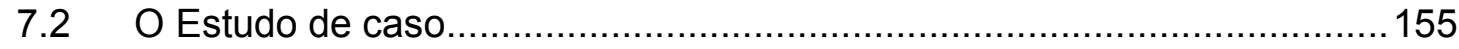

7.2.1 Apresentação e Análise dos Resultados das Entrevistas ..................155

7.2.2 Apresentação e Análise dos Resultados da Avaliação Técnica .........163

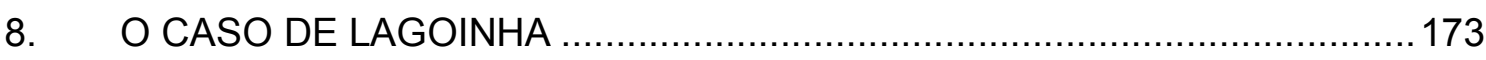

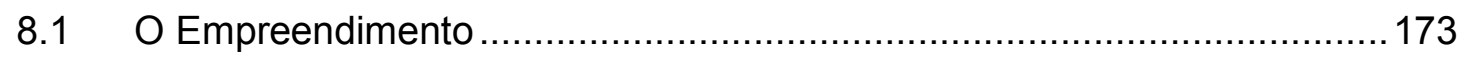

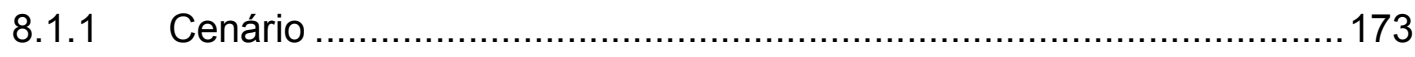

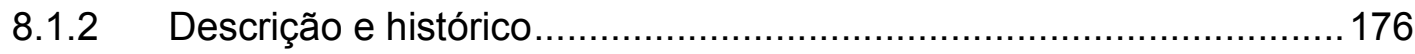

8.1.3 Sistema Construtivo: Alvenaria estrutural com blocos de concreto ... 183

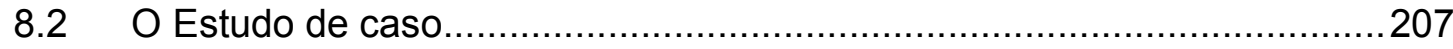

8.2.1 Apresentação e Análise dos Resultados das Entrevistas ...................208

8.2.2 Apresentação e Análise dos Resultados da Avaliação Técnica ........216

9. ANÁLISE E DISCUSSÃO DOS RESULTADOS GLOBAIS..........................229

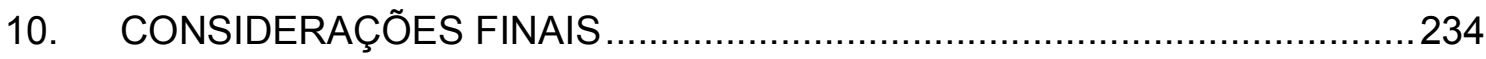

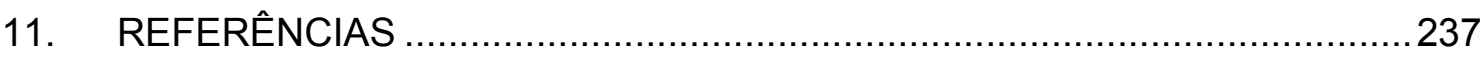

APÊNDICE A - Diretrizes e roteiro para entrevistas em campo ............................244 
APÊNDICE B - Formulário de caracterização dos empreendimentos ....................245

APÊNDICE C - Formulário de visita e entrevista com moradores .........................250

ANEXO A - Quadro resumo do perfil dos municípios visitados ............................258 


\section{INTRODUÇÃO}

\subsection{Contextualização}

O setor habitacional em países em desenvolvimento tem dois grandes problemas, afirmam Mohit et al. (2010). O primeiro é que a quantidade de casas produzidas não atende à demanda da população de baixa renda e o segundo é que o tipo de habitação ofertada não atende satisfatoriamente às necessidades sociais, culturais, religiosas e de conforto das famílias, o que influencia na qualidade de vida e em aspectos psicossociais dos moradores, afirmam os autores.

De acordo com Ferguson e Navarrete (2003), os programas e políticas de habitação nestes países muitas vezes tentam replicar o modo dominante em países desenvolvidos, que consiste na produção de novas unidades habitacionais completas para serem vendidas através de hipotecas ou financiamentos. Esta abordagem de produto, no entanto, exige grandes subsídios por unidade, resulta no setor formal satisfazendo apenas uma fração da demanda das famílias e não consegue gerar os mecanismos necessários para converter a casa própria em uma economia de mercado, bem como em um bem social, asseguram os autores. Eles afirmam, ainda, que esta abordagem do produto aplicada à habitação falhou em todo o mundo em desenvolvimento, no entanto, os governos continuam a financiar unidades completas e de alto custo como a principal forma de provisão habitacional.

Ainda segundo Ferguson e Navarrete (2003), nos países em desenvolvimento a casa própria tem um grande valor devido às diversas incertezas com relação à saúde, estabilidade de emprego e outras situações de emergência que as famílias de baixa e média renda enfrentam frequentemente.

Segundo Van Gelder (2007), as atuais políticas habitacionais visam garantir a posse de terra urbana baseando-se na ideia de que as pessoas precisam de um título legal para consolidar a sua utilização, pois este é uma fonte de segurança e um incentivo para que os moradores realizem melhorias em suas habitações.

Werna et al. (2001) explicam, ainda, que em países em desenvolvimento, a provisão de habitação para baixa renda envolve uma rede intrincada e complexa de relações entre vários agentes e o Estado, o que torna a solução para esses 
problemas ainda mais complicada. Segundo os autores, nestes países, as políticas públicas de provisão habitacional devem levar em consideração o contexto social, cultural e político, a dimensão da oferta de terra e habitação e as interações entre os grupos de interesse relevantes. Eles defendem que, nessas situações, ações como o relaxamento do cumprimento das leis de uso do solo e a grande provisão governamental de serviços básicos de infraestrutura podem contribuir de forma significativa para que a população de baixa renda tenha acesso à moradia digna.

No Brasil, segundo estudo do Ministério das Cidades, o déficit habitacional é estimado em 6,3 milhões de domicílios, entretanto, o déficit qualitativo chega a 10,5 milhões (FUNDAÇÃO JOÃO PINHEIRO, 2009). Isso significa que, além das famílias que não têm um domicílio, uma grande parcela da população vive em habitações inadequadas, com alta densidade demográfica, sem banheiro ou compartilhando o banheiro com outras residências. Outras inadequações, como ambientes sem iluminação ou ventilação não são consideradas nessa conta, o que indica que esse número poderia ser muito maior. Isso significa que há um imenso mercado para novas habitações, principalmente nos segmentos de interesse social e econômico.

Estima-se, ainda, que o país ganhe entre 1 e 1,5 milhão de novas residências por ano. Além disso, algo em torno de 14 milhões de operações de reforma e ampliação são realizadas anualmente, sendo que mais de $75 \%$ das habitações brasileiras necessitam de reformas (ANAMACO \& LATIN PANEL, 2008).

Para atender a toda essa demanda habitacional, diversas formas de provisão podem ser adotadas, de acordo com a população a ser atendida. Assim, Abiko et al. (2005), propõem uma segmentação do setor de construção civil de acordo com uma associação do tipo de gestão, tipo do produto e a clientela atendida:

- produção próprial preço de custo: individualizada, alto padrão, construção por administração, venda a preço de custo ou mercado;

- produção privada imobiliária: condomínio, incorporação, construção e venda a preço fechado, no mercado imobiliário;

- produção e gestão estatal: o estado é o gestor da produção ou gestor do financiamento à produção ou aquisição, com objetivos sociais;

- autoconstrução/ autogestão: construção de baixa renda para a própria família ou para venda; a construção é feita pela própria família, familiares ou mão de obra pouco capacitada. 
Esta pesquisa trata especificamente do terceiro segmento, a produção e gestão estatal, que visa fornecer habitação digna e legalizada à população de baixa renda, muitas vezes removida de áreas de risco ou de assentamentos precários.

Dentro dessa categoria, diversas formas de provisão habitacional têm sido empregadas no Brasil, sendo a grande maioria baseada na construção de empreendimentos de habitação de interesse social (EHIS), também chamados de conjuntos habitacionais.

Entende-se por empreendimentos de habitação de interesse social (EHIS) os empreendimentos desenvolvidos, de forma integral ou parcial, com subsídios do poder público a partir de programas habitacionais para atendimento de famílias com renda mensal na faixa de 0 a 10 salários mínimos (BONATTO et al., 2011).

Em geral, o que diferencia esses empreendimentos são:

- a tipologia, que pode ser horizontal (casas e sobrados) ou vertical (edifícios);

- a forma de construção, que pode ser realizada por uma ou mais empresas contratadas através de licitação ou pelo sistema de mutirão, onde os moradores trabalham na construção das próprias casas sob orientação de profissionais experientes;

- a forma de pagamento, que pode ser totalmente subsidiado, parcialmente subsidiado, totalmente pago ou por meio de arrendamento;

- a titulação de posse dos moradores, que pode ser concedida no momento da entrega da casa, após o pagamento de uma parte do imóvel ou somente ao término do pagamento.

Nas últimas décadas, muito esforço tem sido despendido na construção desses empreendimentos, que concentram a maior parte das tentativas de adoção de processos construtivos racionalizados e inovadores. No entanto, ao longo dos anos, a adoção indiscriminada desses processos inovadores gerou também uma série de problemas de ordem técnica e funcional que na maioria das vezes só veio a se manifestar após a ocupação dos imóveis.

Diante dessa situação, os pesquisadores brasileiros passaram a adotar a avaliação pós-ocupação (APO) como um instrumento não só de avaliação desses empreendimentos, mas também de retroalimentação dos projetos habitacionais voltados à população de baixa renda. 
Segundo Romero e Ornstein (2003), no caso de programas de interesse social, a APO passa a ser ainda mais relevante, pois aí se têm adotado no Brasil, nas últimas décadas, soluções urbanísticas, arquitetônicas e construtivas repetitivas em larga escala para atender a uma população, em geral, muito heterogênea, cujo repertório cultural, hábitos, atitudes e crenças são bastante distintos já no próprio conjunto, e mais ainda em relação aos projetistas.

Segundo Bonatto et al. (2011), os empreendimentos habitacionais de interesse social (EHIS) têm sido alvo de diversos estudos realizados no meio acadêmico, pois entende-se que a busca de melhores resultados em relação a esses empreendimentos gera benefícios aos seus usuários e melhorias para a sociedade, desde que haja bons resultados na relação entre o usuário e o produto oferecido no âmbito dos programas habitacionais pelos diferentes agentes envolvidos. Assim, considerando os recursos investidos em programas habitacionais, eles salientam a importância da formação da satisfação e da geração de valor para a população atendida, a fim de que realmente esses benefícios ocorram de forma duradoura.

No entanto, no contexto de EHIS e analisando avaliações pós-ocupação realizadas no meio acadêmico, é possível perceber, através da repetição dos problemas identificados ao longo dos anos, que as informações e oportunidades para melhorias não são devidamente consideradas na realização de novos empreendimentos (BONATTO et al., 2011).

Segundo Reis (1995 apud BRANDÃO 2011), avaliações pós-ocupação em conjuntos habitacionais mostram, normalmente, a insatisfação com o tamanho da casa e com a adequação dos cômodos. Além disso, o autor declara que, em geral, o morador expressa o desejo de fornecer à sua residência, dentro do que é possível, uma característica individual tanto por dentro como por fora. Apesar disso, os empreendimentos habitacionais, sejam de promoção pública ou privada, são oferecidos, quase sempre, com plantas recorrentes por anos e anos, afirma o autor.

Ainda de acordo com Brandão (2011), a falta de flexibilidade de projeto é uma das principais causas de intervenções, demolição parcial e, até mesmo, a demolição completa de uma edificação. Por essa razão, vários autores defendem a importância da flexibilidade, tanto na ocupação inicial dos espaços, como ao longo de sua utilização. 
Da mesma forma, Concílio e Abiko (1998), falando sobre mutirões habitacionais, afirmam que "a flexibilidade dos processos e sistemas construtivos utilizados para este fim deve ser garantida para acompanhar a natureza evolutiva das construções".

Verifica-se, no entanto, que a grande maioria das avaliações pós-ocupação é feita no campo da arquitetura, levando em consideração mais os aspectos de projeto do que as questões construtivas. Mesmo os estudos que avaliam o processo construtivo, o fazem mais com foco nas patologias identificadas e no conforto ambiental, desconsiderando a influência desses processos na funcionalidade do ambiente construído.

Roméro e Ornstein (2003) reconhecem que há um grande desconhecimento, por parte dos profissionais brasileiros, do que ocorre no ambiente construído no decorrer do uso, tanto no que se refere ao desempenho físico quanto à satisfação do usuário, ou, ainda, no que se refere ao atendimento das suas necessidades. Assim, verifica-se a necessidade de se aprofundar os estudos nesse sentido, buscando compreender melhor essa realidade.

\subsection{Justificativa}

Assim, a pesquisa aqui apresentada se justifica, primeiramente, pela possibilidade de contribuição no aprimoramento de normas e manuais e de alimentação de bancos de dados para retroalimentação de projetos de empreendimentos de HIS, conforme defendido por diversos autores.

Identificou-se, também, a necessidade de se entender melhor o que ocorre no ambiente construído no decorrer do uso, buscando informações sobre o desempenho da edificação e a satisfação do usuário. Por isso, entende-se que é preciso identificar e compreender as modificações realizadas pelos usuários nos empreendimento de HIS, levantando as possíveis causas e as dificuldades para a sua realização.

Outro fator ainda pouco explorado é a influência do processo construtivo na realização dessas modificações, seja por estimular o desejo de mudança ou pela maior ou menor facilidade em permitir as modificações desejadas pelos usuários. Verificou-se, também, que há muitos estudos sobre flexibilidade de projeto em EHIS, mas não se tem estudado como construir essas casas flexíveis, ou seja, é preciso 
entender como os processos construtivos devem se comportar para atender a essa flexibilidade proposta em projeto.

Além disso, entende-se que um estudo mais detalhado dessa relação entre necessidades do usuário, processo construtivo e modificações nas unidades habitacionais em HIS pode servir de base para a elaboração de orientações para futuros empreendimentos.

Assim, esta pesquisa pretende levantar essa questão e abrir caminho para o estudo mais aprofundado dos procedimentos de execução de modificações, principalmente as ampliações, em unidades de HIS. Espera-se, portanto, que este estudo possa contribuir para a elaboração de orientações mais precisas de execução dessas modificações de forma que o resultado final não comprometa a segurança, durabilidade e conforto da habitação.

\subsection{Objetivo}

Com base nesses argumentos, esta pesquisa tem o objetivo de identificar as principais modificações realizadas pelos moradores de empreendimentos horizontais de habitação de interesse social e a sua relação com o processo construtivo utilizado no projeto original.

No intuito de alcançar esse objetivo principal, alguns objetivos secundários foram buscados, conforme especificado a seguir:

- Identificar as principais reclamações dos moradores com relação às unidades de empreendimentos de HIS horizontais;

- Identificar as principais modificações realizadas ou intencionadas pelos moradores nas unidades habitacionais e as possíveis motivações para tal;

- Identificar diferenças nas modificações realizadas em empreendimentos executados com diferentes processos construtivos, buscando identificar a influência desses processos na realização.

\subsection{Hipóteses}

- Os conjuntos habitacionais têm apresentado, ao longo dos anos, diversos problemas técnicos e funcionais; 
- O produto habitacional ofertado à população de baixa renda não atende a todas as necessidades das famílias;

- Os usuários de unidades de HIS demonstram insatisfação com aspectos físicos e funcionais das unidades;

- Os moradores de EHIS modificam as unidades habitacionais para adaptálas às suas necessidades;

- Há muitos estudos sobre a flexibilidade de projeto, mas não se tem estudado como construir essas casas flexíveis.

\subsection{Estrutura da dissertação}

Este trabalho está dividido em dez capítulos, estruturados da seguinte forma:

\section{Capítulo 1: Introdução}

Apresenta a contextualização do problema, as hipóteses, o objetivo, a justificativa e a estrutura da dissertação.

Capítulo 2: Habitação e utilização de sistemas construtivos no Brasil

Exibe um breve histórico das políticas habitacionais do país e da adoção de sistemas construtivos desde o início do século $\mathrm{XX}$, comentando também os desdobramentos dessas políticas no Estado de São Paulo e a utilização de sistemas construtivos inovadores.

\section{Capítulo 3: Avaliação Pós-Ocupação}

Discorre sobre os conceitos, métodos e técnicas de avaliação pós-ocupação. Discute, ainda, os tipos de avaliação e questões relacionadas aos projetos de HIS no Brasil.

Capítulo 4: Modificações realizadas pelos moradores em unidades de HIS Apresenta resumidamente uma revisão da bibliografia existente sobre o assunto no Brasil e apresenta duas opções para minimizar os efeitos das modificações mal realizadas. 


\section{Capítulo 5: Metodologia da Pesquisa}

Esclarece os procedimentos metodológicos adotados para a realização da pesquisa.

Capítulo 6: O Caso de São Luiz do Paraitinga

Apresenta o estudo de caso realizado no Conjunto Habitacional São Luiz do Paraitinga " $C$ ", focando no cenário, na descrição e histórico do empreendimento, no sistema construtivo utilizado e nos resultados encontrados.

\section{Capítulo 7: O Caso de Cunha}

Apresenta o estudo de caso realizado no Conjunto Habitacional Cunha "B", focando no cenário, na descrição e histórico do empreendimento, no sistema construtivo utilizado e nos resultados encontrados.

Capítulo 8: O Caso de Lagoinha

Apresenta o estudo de caso realizado no Conjunto Habitacional Lagoinha "A", focando no cenário, na descrição e histórico do empreendimento, no sistema construtivo utilizado e nos resultados encontrados.

\section{Capítulo 9: Análise Global dos Resultados}

Discute os resultados obtidos nos três estudos de caso, comparando-os e analisando estes resultados de forma global.

\section{Capítulo 10: Considerações Finais}

Apresenta as considerações finais da autora sobre esta pesquisa e sugestões para estudos futuros. 


\section{HABITAÇÃO E UTILIZAÇÃO DE SISTEMAS CONSTRUTIVOS NO BRASIL}

\subsection{Conceituação}

\subsubsection{Casa, moradia e habitação}

Para Martucci e Basso (2002), os conceitos de casa, moradia e habitação são diferentes, embora na sabedoria popular possam parecer o mesmo. Para eles, estes conceitos são os seguintes:

Casa: é o ente físico, a casca protetora, o invólucro que divide espaços internos e espaços externos. Para a construção da casa são utilizados os processos construtivos, com suas técnicas e tecnologias, materiais de construção, componentes, subsistemas e sistemas construtivos. Portanto, é aqui que aparecem as inovações tecnológicas e organizacionais do ponto de vista dos projetos e produção do produto casa.

Moradia: para que a casa se caracterize como moradia, ela precisa se identificar com o "modo de vida" dos usuários nos seus aspectos mais amplos, ou seja, a moradia leva em consideração os "hábitos de uso da casa". Ao longo do tempo, uma casa pode ser utilizada por diferentes pessoas e famílias, transformando-se em moradias diferentes de acordo com os hábitos de seus usuários.

Habitação: está ligada diretamente à estrutura urbana através da infraestrutura urbana instalada e da rede de serviços urbanos. É o resultado da casa e da moradia integradas ao espaço urbano com todos os elementos que este possa oferecer, ou seja, o valor do produto habitação está diretamente relacionado com a estrutura urbana na qual esta inserida. 
Assim, Martucci e Basso (2002) sintetizam a relação entre os conceitos apresentados da seguinte maneira:

CASA + MORADIA + ESTRUTURA URBANA = HABITAÇÃO

\subsubsection{Técnicas, métodos, processos e sistemas construtivos}

Os conceitos de técnicas, métodos, processos e sistemas construtivos muitas vezes são utilizados de forma incorreta até mesmo no meio técnico, sendo confundidos e muitas vezes tratados como sinônimos. Assim, considera-se importante a definição de cada um deles.

Barros (1996) define técnica construtiva como "o conjunto das habilidades de um determinado profissional, no caso presente, operário da construção, para realizar uma determinada operação", ou seja, é o "saber fazer" (CONCíLIO; ABIKO, 1998). Segundo Sabbatini (1989), nestes conceitos "não estão implícitas noções de sequência, precedência, organização, mas tão somente a noção de coleção".

Já o método construtivo é definido por Sabbatini (1989) como "um conjunto de técnicas construtivas interdependentes e adequadamente organizadas, empregado na construção de uma parte (subsistema ou elemento) de uma edificação". Assim, esse conceito engloba as técnicas utilizadas para a construção de um subsistema, como a fundação, vedação ou cobertura, por exemplo.

Se o conceito de método construtivo se refere à construção de um elemento da construção, o conceito de processo construtivo vai mais além e engloba a construção da edificação. Dessa forma, processo construtivo pode ser entendido como um conjunto de métodos construtivos pré-determinados ou como a organização do processo de produção (BARROS, 1996).

Para Sabbatini (1989), processo construtivo é "um organizado e bem definido modo de se construir um edifício. Um específico processo construtivo caracteriza-se pelo seu particular conjunto de métodos utilizados na construção da estrutura e das vedações do edifício (invólucro)".

Segundo Martucci e Basso (2002), os processos construtivos viabilizam, através da tecnologia e da técnica, a materialização das unidades habitacionais e nada mais são do que os processos que definem as formas e as capacidades técnicas e econômicas de se construir. Portanto, do ponto de vista histórico, os processos construtivos estabelecem tipologicamente as tecnologias a serem 
aplicadas, fazendo com que, por sua vez, nos projetos surjam os sistemas construtivos.

Os conceitos de processos e sistemas construtivos são muito próximos, mas apresentam uma relação de subordinação, sendo que a definição de sistemas construtivos apresenta um caráter mais complexo, afirmam Concílio e Abiko (1998).

Martucci e Basso (2002) explicam que os sistemas construtivos representam um determinado estágio tecnológico indutor da forma de se projetar e executar os edifícios, ou seja, sintetizam o conjunto de conhecimentos técnicos e organizacionais referentes aos materiais de construção, componentes, subsistemas construtivos, máquinas, equipamentos, ferramentas e instrumentos produzidos para o setor da construção civil.

Já Sabbatini (1989) define sistema construtivo como "um processo construtivo de elevados níveis de industrialização e de organização, constituído por um conjunto de elementos e componentes inter-relacionados e completamente integrados pelo processo".

Concílio e Abiko (1998) lembram que as definições de Sabbatini (1989) têm sido utilizadas em todos os trabalhos desenvolvidos na Escola Politécnica da Universidade de São Paulo (EPUSP). Dessa forma, adotaremos aqui também essas definições a fim de manter a mesma linha de raciocínio já adotada em trabalhos anteriores.

Martucci e Basso (2002) lembram, ainda, que os sistemas construtivos podem ser subdivididos em vários subsistemas e, nesse sentido, ao iniciar-se a elaboração dos projetos de uma edificação habitacional, tem-se uma infinidade de situações possíveis de serem propostas. Assim, os autores afirmam que praticamente tudo é possível, entretanto, questionam: "será que tudo que é possível no plano projetual será viável do ponto de vista da execução propriamente dita, ou seja, do ponto de vista da produção?".

\subsubsection{Racionalização, industrialização e inovação tecnológica}

Segundo Franco (1996), diversos autores procuraram conceituar a racionalização construtiva. Neste trabalho, utilizamos a definição clássica de Sabbatini (1989): 
"RACIONALIZAÇÃO CONSTRUTIVA é um processo composto pelo conjunto de todas as ações que tenham por objetivo otimizar o uso dos recursos materiais, humanos, organizacionais, energéticos, tecnológicos, temporais e financeiros disponíveis na construção em todas as suas fases."

Para Franco (1996), essa definição mostra que o conceito de racionalização construtiva implica na aplicação dos princípios de racionalização de uma forma mais ampla e não pode ser encarado apenas como a melhoria ou alteração de determinados procedimentos construtivos. Segundo o autor, a racionalização deve abranger todos os recursos envolvidos e todas as fases do empreendimento e, "por suas características, é uma alternativa mais próxima à realidade da indústria da construção civil que outras intervenções mais radicais como a industrialização".

Por sua vez, a industrialização é definida por Sabbatini (1989) da seguinte forma:

"INDUSTRIALIZAÇÃO DA CONSTRUÇÃO é um processo evolutivo que, através de ações organizacionais e da implementação de inovações tecnológicas, métodos de trabalho e técnicas de planejamento e controle, objetiva incrementar a produtividade e o nível de produção e aprimorar o desempenho da atividade construtiva."

Para este autor, deve-se conduzir os esforços no sentido de industrializar a construção civil de forma a construir quantidade igual ou superior de edificações com qualidade igual ou superior a um custo menor.

Sabbatini (1989) apresenta, ainda, uma definição do conceito de inovação tecnológica específica para o campo da tecnologia de construção de edifícios:

"Um novo produto, método processo ou sistema construtivo introduzido no mercado, constitui-se em uma INOVAÇÃO TECNOLÓGICA na construção de edifícios quando incorporar uma nova idéia e representar um sensível avanço na tecnologia existente em termos de: desempenho, qualidade ou custo do edifício, ou de uma sua parte."

Franco (1996) defende que a adoção dos princípios de racionalização da construção leva à busca de melhores soluções e, consequentemente, permite o aprimoramento contínuo dos processos construtivos, o que pode ser estendido também à aplicação da industrialização na construção.

O autor argumenta, ainda, que "a implementação de inovações tecnológicas deve estar baseada em análises feitas através de metodologias científicas, fundamentadas em critérios como construtibilidade e desempenho". Assim, é 
possível obter melhorias de produtividade e custo, mas garantindo o funcionamento adequado e o atendimento das expectativas dos usuários das habitações.

\subsection{A habitação no Brasil a partir do final do século XIX}

A expansão das atividades industriais nas cidades no final do século XIX resultou na migração da população para essas regiões e trouxe também a necessidade de gerar habitações nos grandes centros urbanos, lembra Lima (2008). Segundo o autor, a grande maioria das moradias era construída de forma artesanal por meio da autoconstrução. Próximo à virada do século, no entanto, o aumento do proletariado, os cortiços lotados e o surgimento das primeiras favelas gerou uma pressão pela provisão de habitação de baixo custo e muitos empresários passaram a construir vilas operárias para abrigar seus funcionários em troca de redução de taxas e impostos por parte do governo, afirma.

No entanto, segundo Palhares (2001), no início do século XX, grande parte da população brasileira ainda vivia em casas de aluguel e tinha grande parte do salário absorvida pelas mensalidades. De acordo com o autor, o Estado Novo, de 1930 a 1945, marcou um período de nova reflexão sobre as habitações de massa para a classe operária e de formação de uma nova cultura de morar.

Segundo Palhares (2001), o Estado assumiu a responsabilidade pelo problema habitacional e passou a intervir na produção das moradias, provocando grandes transformações no setor habitacional. A aquisição da casa própria passou a ser o objetivo principal a e política habitacional priorizava o barateamento do custo de produção, sem comprometer as condições de conforto e higiene para os moradores, tomadas como condições mínimas de habitabilidade.

Palhares (2001) relata que foi nessa época que surgiram os Institutos de Aposentadoria e Pensão (IAP's) e a Fundação da Casa Popular (FCP), os primeiros órgãos federais de atuação voltada ao suporte à produção de habitação social, introduzindo novos arranjos e tipologias e criando tendências urbanísticas inovadoras. Segundo o autor, o modelo adotado inicialmente buscava prioritariamente a melhoria da qualidade de vida dos moradores, entretanto, o fator econômico prevalece, estabelecendo a construção com custo mínimo e predomínio de moradia em edifícios coletivos para os associados. Ocorre, então, a busca pelo 
melhor aproveitamento dos recursos a serem disponibilizados, com a padronização dos materiais de construção, reprodução em série e industrialização.

$\mathrm{Na}$ década de 40, a residência unifamiliar isolada continuava sendo a preferência, entretanto, foram adotados programas inovadores para construção de edifícios de moradia com apartamentos duplex, teto jardim e pilotis, associados a equipamentos sociais e recreativos, áreas verdes e de lazer etc. A partir de 1945, com a adoção de valores estritamente econômicos, tais modelos perderam parte dos conteúdos modernistas e levaram à racionalidade da planta através da redução dos espaços internos, mas tentando preservar as condições de conforto e higiene dos moradores. Ainda assim, passaram a sofrer grande rejeição (PALHARES, 2001).

Segundo Palhares (2001), o período de pós-guerra foi marcado pela crise habitacional provocada pelo fim da guerra e pela Lei do Inquilinato, que congelou o valor dos aluguéis. Mesmo assim, continuou a produção de habitação popular de massa no período, baseada nas tipologias de casas unifamiliares térreas, sobrados geminados e blocos laminares de apartamentos, sobretudo nas periferias, onde os lotes apresentavam custos mais baixos.

O processo colocado em prática com maior frequência neste período tinha como foco a industrialização das partes e não do todo. Acreditava-se que as vantagens da industrialização seriam vistas na exatidão das medidas e no encaixe perfeito das partes no canteiro de obras, acelerando a montagem e reduzindo o tempo de execução e o custo da mão de obra (FOLZ, 2008).

Nas décadas de 50 e 60, os IAP's entraram em declínio e passaram a funcionar com subsídios da União, afirma Lima (2008). Além disso, o processo de favelização continuou acelerado e a autoconstrução se manteve como principal forma de produção habitacional, completa. Também nessa época, tentou-se implantar o Plano de Assistência Habitacional (PAH) para substituir a Fundação da Casa Popular (FCP) e o Instituto Brasileiro de Habitação (IBH), que não foram bem sucedidos, revela o autor.

Com a instituição do governo militar, teve fim o congelamento dos aluguéis e foi criado, em 1964, o Banco Nacional de Habitação (BNH), que assumiu o desafio da provisão de moradia e também de desenvolvimento urbano, sendo responsável por elevar o nível de coordenação e sistematização da intervenção do Estado na provisão da habitação popular (MARROQUIM; BARBIRATO, 2007; PALHARES, 
2001; LIMA, 2008). De acordo com Lima (2008), nos dois primeiros anos, os recursos do $\mathrm{BNH}$ vinham do percentual de $1 \%$ das folhas de pagamento e, a partir de 1966, o banco passou a operar por meio do Sistema Financeiro da Habitação (SFH), composto pelo Fundo de Garantia por Tempo de Serviço (FGTS) e pelo Sistema Brasileiro de Poupança e Empréstimo (SBPE).

Assim, foi adotado um plano de construção intensiva de unidades para venda por meio do financiamento da habitação popular, crescendo o estímulo à obtenção da casa própria. Se por um lado o objetivo era incentivar a obtenção da casa própria, por outro, pretendia-se criar condições favoráveis ao desenvolvimento da indústria da construção civil e gerar mais empregos (PALHARES, 2001; LIMA, 2008).

Pouco antes dos anos 70, o país experimentou um período de grande crescimento denominado "Milagre Econômico". O país crescia rapidamente na área econômica e a expansão industrial, aliada à melhora dos índices salariais e à repressão política, incitou uma explosão consumista entre os setores médios da população. O período foi marcado pela execução de grandes obras da iniciativa pública e significativa expansão do crédito.

Segundo Lima (2008), os agentes designados para implantar esse programa foram as Companhias de Habitação (COHAB's), que atendiam famílias com renda na faixa de 1 a 3 salários mínimos, e os Institutos de Orientação a Cooperativas Habitacionais (INOCOOP's), que atendiam famílias com renda na faixa de 3 a 5 salários mínimos. Segundo o autor, as propostas arquitetônicas adotavam a prática de maior quantidade possível de habitações em espaços menores e em larga escala, utilizando-se dos superblocos.

Também nesse período, questionou-se a competência da indústria da construção e intensificaram-se as discussões quanto ao "atraso tecnológico" do setor e questões como o aumento da produtividade e redução de custos passaram a ter maior importância devido à produção de bens de consumo em massa (HOLANDA, 2003). Gonçalves et al. (2003) descrevem que, a partir dos questionamentos, verificou-se a oportunidade da utilização de novos sistemas construtivos (como alternativas aos produtos e processos tradicionais até então utilizados) visando, principalmente, a racionalização e industrialização da construção.

Segundo Farah (1996 apud HOLANDA, 2003), a introdução de "sistemas construtivos inovadores" ou ainda "sistemas industrializados", baseados na pré- 
fabricação, na maioria trazidos de outros países, foi a resposta dada pelas empresas construtoras de edifícios aos questionamentos e discussões sobre o atraso do setor. HOLANDA (2003) conta que, do final da década de 60 até o início da década de 80 , a construção de grandes conjuntos habitacionais também marcou uma etapa importante da história da construção de edifícios no Brasil, com alterações tecnológicas voltadas para a industrialização da construção.

O otimismo tecnológico que existia até então entrou em crise no final da década de 70 e as propostas, baseadas na repetição de elementos e espaços préfabricados e em sistemas construtivos fechados, não tiveram continuidade devido ao seu alto custo. Neste momento, Folz (2008) descreve o surgimento de uma nova visão para se produzir edifícios: a visão sistêmica, onde não se separa o edifício como um todo e sua interação com o usuário e o meio.

De acordo com Marroquim e Barbirato (2007), grande parte dos empreendimentos construídos entre as décadas de 60 e 80, financiados pelo $\mathrm{BNH}$, custava caro e não atendia às necessidades de seus proprietários, com destaque para as dimensões reduzidas. De acordo com Palhares (2001), as propostas tipológicas do BNH estavam longe das articulações dos IAP's, mas mantinham o padrão de casas térreas, sobrados e blocos de apartamentos. $\mathrm{O}$ autor caracteriza a atuação do BNH pela busca pela economia e priorização do atendimento de demanda quantitativa, resultando na redução progressiva da área construída das habitações e da qualidade de seus materiais de acabamento.

Segundo Bonduki (2008), é necessário enfatizar, ainda, o desastre, do ponto de vista arquitetônico e urbanístico, da intervenção realizada. Para o autor, dentre os erros praticados se destacam a opção por grandes conjuntos na periferia, a desarticulação entre os projetos habitacionais e a política urbana e o absoluto desprezo pela qualidade do projeto. O resultado foram soluções padronizadas e sem nenhuma preocupação com a qualidade da moradia, com a inserção urbana, com o respeito ao meio físico e com as peculiaridades de cada região do país, afirma.

O BNH foi extinto em 1986 e, segundo Palhares (2001), durante 22 anos, o banco financiou casas para a população de todas as faixas de renda através da promoção pública e, principalmente, pela promoção privada da incorporação imobiliária. De acordo com o autor, o $\mathrm{BNH}$ financiou praticamente $25 \%$ do incremento de moradias construídas no Brasil neste período, sendo que menos de 
$20 \%$ deste total se destinou à concessão de financiamento de habitação às famílias de baixa renda.

Apesar das críticas ao BNH e ao seu sistema, Bonduki (2008) acredita que sua importância é indiscutível, pois foi neste período (1964-86) que o país teve, pela primeira vez, uma Política Nacional de Habitação.

Com a extinção do BNH no final da década de 80, a Caixa Econômica Federal (CEF) assumiu a gestão do FGTS, com uma articulação insatisfatória, e cresceu a expansão desordenada das periferias e favelas nas médias e grandes cidades (LIMA, 2008).

Segundo Palhares (2001), o desmonte da estrutura operacional comandada pelo BNH e a desarticulação do SFH alertaram para a necessidade de formulação e execução de uma nova política habitacional de interesse social. Assim, a partir da segunda metade da década de 80 , principalmente com a Constituição de 1988 , é reduzida a centralização das decisões do Governo Federal na alocação de recursos em favor do fortalecimento do papel dos Estados e Municípios na execução da política habitacional, o que só se consolida no início da década de 90 , relatam Palhares (2001) e Lima (2008).

Segundo Bonduki (2008), a fase denominada de pós-BNH foi marcada pela transição entre a existência de uma política nacional de habitação e a atuação fragmentada, mas criativa, dos Estados e municípios. Assim, segundo o autor, a intervenção governamental passou a ser realizada com recursos oriundos de outras fontes e em parceria com a sociedade organizada.

Werna et al. (2001; 2004 apud LIMA et al., 2011) afirmam que observou-se, no Brasil e em outros países em desenvolvimento, uma tendência de reduzir a intervenção direta dos agentes públicos no processo de provisão e de estimular a participação de agentes não públicos. Segundo os autores, esta prática estabeleceu uma rede intrincada e complexa de relações entre vários agentes e o Estado, que passaram a operar de maneira fragmentada, resultando em uma ampla gama de influências políticas, sociais e culturais.

Começa, então, a entrada de empresas de construção pesada no setor de edifícios, promovida pela redução de investimentos governamentais. Estes fatores desencadearam o aumento da concorrência na área e, como estratégia para enfrentá-la, as empresas buscaram, mais uma vez, a racionalização na produção de 
edifícios (BARROS, 1998). A partir daí, entretanto, a década foi bastante estagnada. Nos anos 90 não havia pressa para se construir. De acordo com Holanda (2003), nesse período o setor de edificações passou por diversas mudanças, consolidandose a partir daí uma nova situação de mercado, provavelmente em consequência da menor intervenção do Estado.

Ainda de acordo com Bonduki (2008), emerge nessa época um amplo conjunto de experiências municipais de habitação de interesse social, realizadas a partir da redemocratização do país, marcando uma fase de diversidade de iniciativas, mas pouco articulada em decorrência da ausência de uma política nacional. Segundo ao autor, nesta fase, surgem, além das intervenções tradicionais, programas que adotam pressupostos inovadores como desenvolvimento sustentável, diversidade de tipologias, estímulo a processos participativos e autogestionários, parceria com a sociedade organizada, reconhecimento da cidade real, projetos integrados e a articulação com a política urbana.

Em 1995, com o início do governo Fernando Henrique Cardoso, ocorre uma retomada nos financiamentos de habitação e saneamento com base nos recursos do FGTS, interrompidos no governo Collor, entre 1991 e 1995 (BONDUKI, 2008).

Embora não tenha sido criada, de fato, uma política habitacional, Bonduki (2008) acredita que os pressupostos gerais que presidiram a formulação dos programas habitacionais incorporaram princípios como flexibilidade, descentralização, diversidade, reconhecimento da cidade real, entre outros, rejeitando os programas convencionais, baseados no financiamento direto à produção de grandes conjuntos habitacionais e em processos centralizados de gestão.

No decorrer dos anos descritos, a partir da atuação do BNH e até o início dos anos 2000, é possível perceber que a busca por processos racionalizados de construção levou à implantação de tecnologias ainda não suficientemente desenvolvidas ou adaptadas às necessidades do país, gerando, na maioria dos casos, experiências desastrosas. Os resultados geraram prejuízos para todos os agentes intervenientes no processo de construção. Para os usuários, foram transferidos os problemas de patologia e os altos custos de manutenção e reposição provocados. E, para o setor da Construção Civil, as experiências negativas tornaram 
o setor menos receptivo às inovações tecnológicas, com progressiva desatualização tecnológica em relação aos demais setores produtivos (GONÇALVES et al., 2003).

Gonçalves et al. (2003) avaliam que, simultaneamente a todas estas propostas de soluções inovadoras, surgiu a necessidade de avaliá-las tecnicamente, com base em critérios que permitissem prever o comportamento do edifício durante sua vida útil esperada. Ficam mais fortes, então, a partir dos anos 60 e 70, os apelos pela avaliação pós-ocupação (APO), com o surgimento de estudos focamos principalmente na avaliação de desempenho dos sistemas construtivos.

Roméro e Ornstein (2003) relatam que, com o passar dos anos, houve uma mudança na maneira de encarar a questão habitacional e os poderes públicos passaram a respeitar muito mais o assentamento existente, procedendo ao que se tem chamado de reurbanização de favelas e cortiços. Entretanto, a construção de conjuntos habitacionais continuou sendo uma prática muito adotada no combate ao déficit habitacional.

Em 2003, o recém-iniciado governo Lula criou o Ministério das Cidades, que é hoje um dos principais responsáveis pela política habitacional do país. Através dele, o governo introduziu algumas medidas, como a redução da taxa de juros, criação de subsídios para aquisição de imóveis novos e para construções, dilatação de prazos de financiamentos, simplificação e agilidade dos processos de contratação e uma forte publicidade (NOAL; JANCZURA, 2011).

Com essas medidas, a construção civil voltou a crescer, atingindo o auge em 2007, até que, em 2008, uma crise econômica internacional ameaçou fortemente as empresas do setor, gerando desconfiança nos investidores. Em 2009, o Governo Federal lançou o Programa Minha Casa, Minha Vida com o objetivo de incentivar a produção e aquisição de unidades habitacionais e, ao mesmo tempo, combater a crise através da criação de empregos e investimentos no setor da construção civil. A estratégia deu certo e, novamente, o país passa por um período de grande crescimento do crédito para a habitação e construção de grandes empreendimentos, em sua maioria de caráter privado, impulsionando mais uma vez a busca por sistemas racionalizados (SILVESTRE; CARDOSO, 2012b).

Várias críticas surgiram, no entanto, com relação ao programa, sendo que muito se tem falado dos baixos padrões de qualidade e desempenho das novas edificações, independentemente do sistema construtivo adotado. Para minimizar 
esses problemas, foram criados o Sistema Nacional de Aprovações Técnicas (SINAT) e a Norma de Desempenho para Edifícios Habitacionais (KISS, 2011).

\subsubsection{Políticas Habitacionais das últimas décadas no Estado de São Paulo}

A responsável pela condução da política habitacional do Governo do Estado de São Paulo é a Secretaria da Habitação, que traça diretrizes, estabelece metas, planeja e desenvolve programas específicos através da Companhia de Desenvolvimento Habitacional e Urbano do Estado de São Paulo (CDHU), empresa do Governo Estadual, vinculada à Secretaria da Habitação, que é o maior agente promotor de moradia popular no Brasil (SILVA, 2012).

De acordo com Silva (2012), o objetivo da CDHU é executar programas habitacionais em todo o território do Estado, voltados para o atendimento exclusivo da população de baixa renda, atendendo famílias com renda na faixa de 1 a 10 salários mínimos. A autora afirma que o desafio macro da empresa "é manter a produção de habitações em grande escala, a preços de custo, visando combater o déficit habitacional do Estado". Além disso, a CDHU também intervém no desenvolvimento urbano das cidades.

A CDHU foi fundada em 1949 e já teve diversos nomes, recebendo a atual denominação em 1989.

Segundo Namur (2004), a CDHU vem realizando um grande esforço de superação do déficit de novas unidades habitacionais no Estado de São Paulo desde os anos 80. A autora afirma que, desde 1987, vários programas foram implantados, entre os quais os Programas $\mathrm{SH} 1, \mathrm{SH} 2, \mathrm{SH} 3$ e SH4, através de obras por empreitada, realizadas em parceria com a iniciativa privada e com as prefeituras, e programas de mutirão, em parceria com movimentos populares organizados em associações.

Desde 1990, em função do fluxo ininterrupto de recursos financeiros gerados pela destinação de $1 \%$ do ICMS para a produção habitacional, houve um aumento da produção, principalmente em municípios do interior do Estado. Com isso, iniciouse a instalação de Escritórios Regionais, numa tentativa de iniciar um processo de descentralização das ações da CDHU (SILVA, 2012).

Segundo Silva (2012), a partir de 1995, com a mudança de comando no Governo do Estado de São Paulo, a CDHU expandiu e diversificou ainda mais sua 
produção, tornando-se um importante agente indutor de desenvolvimento econômico e urbano.

Namur (2004) destaca, entre os programas recentes da CDHU, o Programa Habiteto ou Cesta de Materiais de Construção, criado em 1995 pelo governador Mário Covas. Ela explica que tratava-se de um programa de financiamento de recursos para a construção de unidades habitacionais em regime de autoconstrução ou mutirão, voltado ao atendimento prioritário de famílias com renda de até três salários mínimos. As casas seguiam projetos padronizados da CDHU e continham um ou dois dormitórios, sala, cozinha e banheiro, com áreas de $36 \mathrm{~m}^{2}$ a $40 \mathrm{~m}^{2}$, afirma a autora.

A participação dos municípios se dava através da doação de áreas para a implantação dos empreendimentos habitacionais e da execução das obras de infraestrutura, afirma a autora (NAMUR, 2004).

Visando enfrentar a carência habitacional e urbana que atinge a população paulista, a Secretaria de Estado da Habitação e a CDHU estabeleceram, entre os anos de 2007 e 2008, novas diretrizes e ações estratégicas para minimizar as necessidades mais urgentes e encontrar soluções habitacionais inovadoras e duráveis (TRANI et al., 2008).

Assim, Trani et al. (2008) afirmam que houve uma otimização do aparato administrativo e institucional no setor de HIS, o que "promoveu importantes mudanças no padrão de produção das moradias e núcleos urbanos". Ainda de acordo com estes autores, essas modificações envolvem a composição do público atendido, o padrão das moradias e do espaço urbano e a regularização fundiária. As principais modificações citadas por estes autores são:

- Regularização fundiária: os empreendimentos construídos com verba pública não podem ser entregues antes da regularização e averbação e os empreendimentos ainda irregulares tiveram seus processos de regularização acelerados.

- Novos modelos de projetos habitacionais: a área útil das unidades foi ampliada de $42 \mathrm{~m}^{2}$ para $64 \mathrm{~m}^{2}$ e passaram a ser ofertadas casas com três dormitórios.

- Aperfeiçoamento nas moradias e no espaço urbano: melhoria nos acabamentos, aumento do pé-direito de 2,40m para 2,60m, casas 
entregues com muros divisórios e valorização da paisagem urbana através de projetos que se preocupam em evitar o excesso de padronização das paisagens.

- Desenho universal: casas projetadas de acordo com os conceitos de desenho universal, que permitem a adaptação para pessoas com deficiências, idosos, gestantes e crianças.

- Cuidado com o meio ambiente: alinhamento com as políticas ambientais, otimização do uso de recursos naturais na construção e no uso das edificações, medição individual de água, que garante redução do desperdício, e instalação de sistemas de aquecimento solar.

- Ampliação do conceito de família: mudança nas regras de atendimento das famílias para atender às mudanças da sociedade.

\subsection{A etapa de projeto na construção civil}

No Brasil, a falta de qualidade dos projetos tem sido apontada como uma das principais barreiras para o avanço tecnológico e organizacional da indústria de construção de edifícios (GRILO et al., 2003). Segundo Fabrício, Baía e Melhado (1998), os projetos na construção de edifícios têm um papel fundamental na qualidade dos produtos e na eficiência dos sistemas de produção, mas, apesar disso, têm sido tratados como uma atividade secundária que é, via de regra, delegada a projetistas independentes, contratados por critérios preponderantemente de preço do serviço.

Os autores destacam, ainda, que os projetos no setor são orientados para a definição do produto sem considerar adequadamente a forma e as implicações quanto à produção das soluções adotadas. Eles afirmam, ainda, que as definições e detalhamentos de produto são, muitas vezes, incompletos e falhos, sendo resolvidos durante a obra, quando a equipe de produção acaba decidindo sobre determinadas características do edifício não previstas em projeto.

Villa (2009) corrobora com essa opinião, afirmando que não é praxe no mercado a busca pela tecnologia do projeto, que poderia ser melhorada com incrementos no setor de coordenação desses projetos e com investimento em 
pesquisas e avaliações pós-ocupações para formação de bancos retroalimentadores de projetos.

Mas, embora uma parcela significativa das falhas ocorra na etapa de projeto, ou seja, naquela de menor custo, Roméro e Ornstein (2003) destacam que os programas de qualidade no Brasil ainda estão mais voltados à execução e à fabricação de materiais e de componentes, visando ao aumento de produtividade da mão de obra e à redução de desperdícios.

Segundo estes autores, são poucas as empresas de consultoria e construtoras que conhecem ou já implantaram programas de controle de qualidade da etapa de projeto, resultando em poucos profissionais com experiência no assunto. Assim, o fator qualidade só é considerado quando se pretende atender ao "contratante" e raramente se considera o usuário final (morador), o que gera um impacto socioambiental ainda maior no caso de conjuntos habitacionais para a população de baixa renda, afirmam.

Por outro lado, Palhares (2001) acredita que os interesses econômicos e os compromissos eleitoreiros acabam por estabelecer um prazo político incompatível com o prazo técnico mínimo necessário para investigação, concepção e desenvolvimento do projeto dos empreendimentos de HIS. Da mesma forma, Gao e Asami (2011) afirmam que, historicamente, a regulamentação do tamanho das habitações tem sido uma questão política em muitos países, pois o tamanho e a localização são grandes influenciadores do preço destas habitações, sendo definidos sempre de modo que se obtenha o custo mínimo.

Segundo Palhares (2001), neste contexto, o trabalho do arquiteto fica reduzido a um mero exercício de implantação de tipologias, onde, a partir de um terreno escolhido, procede-se à determinação de adensamento máximo e estabelecem-se quadras e lotes com dimensões mínimas e, na maioria das vezes, adota-se uma tipologia única de habitação. Esta tipologia, afirma o autor, quase sempre é definida através de programas de necessidades estabelecidos a partir de parâmetros mínimos de habitabilidade impostos por agentes promotores da política habitacional.

Além disso, há uma gama de pesquisadores que defendem que a padronização dos conjuntos habitacionais brasileiros torna as habitações impessoais, o que impossibilita o estabelecimento de relações entre o usuário e a 
edificação (SZÜCS, 1998b; SILVEIRA; RAMOS, 2000 apud MARROQUIM; BARBIRATO, 2007). De acordo com Palhares (2001), uma proposta tipológica sem flexibilidade para futuras modificações dificilmente atenderia a todos os grupos distintos sem conflitos.

Gao e Asami (2011) acreditam, ainda, que o tamanho das habitações está diretamente associado ao benefício destas para as famílias. Eles afirmam que, se a casa for muito pequena, a sua funcionalidade pode ser incompleta e o conforto e a flexibilidade são reduzidos, tornando difícil para as famílias adaptá-la às mudanças ao longo da vida. Por outro lado, se a casa for muito grande, os custos de construção e os custos futuros com energia e manutenção podem ser desnecessariamente altos, afirmam.

Assim, Palhares (2001) defende que as proposições de projeto devem considerar as necessidades, atividades, valores, cultura e os modos de vida próprios dos moradores para que possam efetivamente contribuir para a melhoria da qualidade de vida e influenciar os agentes promotores das políticas habitacionais a efetivarem mudanças. Ele conclui que é necessário questionar os conceitos que orientam a prática destes projetos de natureza social, bem como o processo de criação e produção.

Nesse contexto, Martucci e Basso (2002) apresentam três princípios básicos para a elaboração do projeto do produto de edificações:

1. atendimento aos requisitos, condições e parâmetros dados pelas características regionais e capacidade tecnológica instalada;

2. atendimento aos requisitos funcionais e ambientais; e

3. atendimento aos princípios de racionalização do produto quanto à sua produção.

\subsection{Adoção de sistemas construtivos inovadores}

O setor da construção civil carece, há muito tempo, de investimentos em tecnologia e processos racionalizados de produção. Segundo Abiko et al. (2005) "o setor de construção de edifícios habitacionais no país tem apresentado, historicamente, uma lenta evolução tecnológica, comparativamente a outros setores industriais". A falta de investimentos no desenvolvimento dos processos de produção, a utilização de materiais muitas vezes sem qualidade, o desestímulo ao 
uso de componentes industrializados devido à alta incidência de impostos, a falta de capacitação técnica dos agentes da cadeia produtiva e a pouca capacitação da mão de obra, dentre outros fatores, resultam em baixa produtividade e elevados índices de desperdício de materiais e de mão de obra, caracterizando a construção civil como um setor com baixo índice de industrialização.

Por outro lado, Andery et al. (2004) caracterizam o mercado de produção de edificações como um segmento em busca da redução de prazos na elaboração dos projetos e na execução das obras, com crescente competitividade e preocupado com a integração da cadeia produtiva, contexto que pode ser estendido aos dias de hoje. Diante desse cenário, nota-se nas empresas do setor uma maior busca por processos de gestão e execução que auxiliem na racionalização e avaliação das atividades desenvolvidas.

O setor como um todo carece de meios para aumentar a produtividade e eficiência dos seus processos, mas, sobretudo nos segmentos voltados à população de baixa renda, a racionalização e a industrialização da construção são de fundamental importância para garantir o acesso dessa população a uma habitação segura, salubre e confortável, que Ihes ofereça uma boa qualidade de vida, porém, a um custo compatível com as suas possibilidades financeiras.

De acordo com Salvador Filho (2007), "o desafio da inovação na construção civil é o de permitir melhores construções em termos econômicos, produtivos e de qualidade". Para o autor, é possível atingir essa qualidade com a produção de materiais e processos industrializados que permitam a produção de habitações de diversos padrões com altíssima qualidade.

No entanto, segundo Kellett e Franco (1993), diversos estudos têm mostrado a aceitação relutante e até mesmo a rejeição de certos materiais e sistemas construtivos por parte dos moradores como uma limitação dos projetos.

Esse fato pode ser explicado porque, ao longo dos anos, a experimentação de sistemas construtivos inovadores em empreendimentos de HIS gerou uma série de problemas patológicos e funcionais de difícil solução. Em muitos casos, a manutenção por parte dos moradores foi dificultada pela falta de conhecimento do sistema construtivo ou pela falta de peças de reposição.

Para Martucci e Basso (2002), diante de um quadro amplo de possíveis soluções tecnológicas e ambientais, "seria muito temerário que se pusesse à 
disposição de usuários leigos tecnologias não testadas ou avaliadas, tanto do ponto de vista laboratorial, quanto do ponto de vista do 'design'". Segundo os autores, muitas dessas tecnologias ainda não tiveram o tempo necessário para uma maturação teórico-conceitual do seu projeto do produto e do projeto da produção que thes desse as condições e características básicas para uso massivo. Outras tecnologias, embora já tenham passado por testes de laboratório em seus componentes básicos, em momento algum foram testadas e avaliadas cientificamente de acordo com a sua estrutura conceitual de concepção e desenvolvimento como casa/moradia, avaliam.

Hoje, diante do novo momento econômico do país, onde a construção civil ganha força e os empreendimentos de HIS se multiplicam, ressurge a discussão sobre a utilização de sistemas inovadores. Por um lado, as empresas buscam a redução de prazos e custos através da melhoria de seus processos e de outro, alguns pesquisadores e moradores rejeitam a adoção de novos sistemas construtivos temendo a repetição dos erros do passado.

É importante deixar claro, no entanto, que não se pode "fechar as portas" para as inovações, pois elas são necessárias ao setor e podem contribuir muito para a garantia da provisão de habitações de baixo custo e alta qualidade para a população de baixa renda.

Assim, Salvador Filho (2007) defende que a introdução de processos inovadores deve ser precedida de uma adaptação às condições culturais, técnicas, sociais, econômicas e políticas do país, pois estes processos terão que interagir coerentemente com os já existentes para representarem uma solução construtiva eficiente e eficaz.

Seguindo o mesmo raciocínio, Martucci e Basso (2002) defendem que é de fundamental importância que sejam realizadas, dentro de programas que incentivem as inovações tecnológicas, avaliações com amplitude suficiente para detectar os impactos que estas novas tecnologias causam no meio ambiente. Eles acreditam que essas avaliações devem detectar se realmente as inovações estão sendo implantadas no sentido de beneficiar significativamente os usuários no que tange à qualidade destes novos produtos.

Segundo Salvador Filho (2007), a Caixa Econômica Federal considera oportuno o desenvolvimento de inovações tecnológicas para aumentar o acesso da 
população de baixa renda à habitação, sendo este um elemento estratégico para o desenvolvimento do setor e do próprio país. No entanto, o autor afirma que a adoção da inovação na construção civil exige que a sua superioridade frente aos métodos tradicionais seja comprovada. Para tanto, deve-se ter em mente que a comparação de custos deve levar em conta a economia nos custos indiretos, pois a comparação direta de valores de componentes inovadores com tradicionais pode acarretar em custos mais elevados. Assim, é importante considerar os custos da adoção dos sistemas e não de componentes isolados.

O fato é que, sem referência técnica ou norma, nenhum sistema construtivo alcança os programas habitacionais e financiamentos que permitem a utilização em larga escala. Conforme Kiss (2011), uma das saídas pode estar no recém-criado SINAT que, embora tenha sido concebido em 2007 dentro do Programa Brasileiro de Qualidade e Produtividade do Habitat (PBQP-H), só agora começa a tomar forma com as primeiras deliberações dos comitês técnico e nacional. $O$ autor declara que 0 SINAT, juntamente com a Norma de Desempenho para Edifícios Habitacionais (NBR 15575), potencializará a inovação a fazer parte efetiva do setor da construção.

Ainda assim, entende-se que é necessária a criação de meios para que o consumidor, ao adquirir produtos inovadores, tenha como avaliar a sua qualidade, sabendo que a sua habitação não é fruto de experiências e que há estudos sérios e precisos como suporte ao produto oferecido, como defende Salvador Filho (2007).

Kellett e Franco (1993) defendem que essa área de investigação merece mais atenção e estudos e que não só os moradores precisam ser convencidos das vantagens dos novos sistemas, mas também as autoridades e agências locais responsáveis pela aceitação oficial de materiais e sistemas construtivos inovadores. 


\section{AVALIAÇÃO PÓS-OCUPAÇÃO}

\subsection{Conceituação}

O conceito de qualidade vem se modificando ao longo do tempo, incorporando aos conceitos iniciais, relacionados às conformidades normativas, questões relativas à percepção do usuário (PICCHI, 1993 apud MORAES; SANTANA, 2004).

Moraes e Santana (2004) salientam que questões referentes à qualidade têm sido cada vez mais discutidas nos diferentes setores e contextos, desde a questão dos padrões de qualidade na indústria até a questão da qualidade de vida no contexto do desenvolvimento sustentável.

Segundo Lawrence (1995), a qualidade da habitação é um conceito complexo e relativo, que pode variar entre os países e também entre grupos específicos de pessoas em cada país, tanto em um ponto no tempo como por longos períodos. Ele acredita que essa questão não deve ser considerada apenas do ponto de vista técnico ou arquitetônico, estando também associada a questões econômicas e políticas.

Roméro e Ornstein (2003) definem o termo "qualidade" como "os aspectos do produto ou serviço que satisfazem as necessidades do usuário", ou seja, está associado claramente ao desempenho satisfatório dos ambientes e das relações ambiente \& comportamento (RAC).

Essa visão é reafirmada por Moraes e Santana (2004), que lembram que cada vez mais, o conceito de qualidade vem sendo associado ao de satisfação do usuário, o que o remete a questões subjetivas, em concordância com diversos aspectos relacionados ao desenvolvimento sustentável em cidades, à qualidade de vida, qualidade ambiental urbana e à qualidade das habitações.

A definição de qualidade aqui adotada é a mesma adotada por estes autores, que leva em consideração tanto as análises técnicas sobre o produto quanto a satisfação do usuário, seus sentimentos, vivência e expectativas:

"a qualidade é a resultante de fatores objetivos (projeto, qualidade dos materiais e execução) e subjetivos (vivência, expectativas, apropriação e 
identificação com o objeto), que interagem de forma a compor o cenário no qual o produto ou serviço é avaliado" (MORAES; SANTANA, 2004).

Lawrence (1995) acredita que uma abordagem integrada para a qualidade da habitação deve considerar explicitamente políticas ambientais urbanas e programas de habitação a preços acessíveis que vão além da formulação de políticas baseadas em medidas corretivas e de reparação. $O$ autor afirma que é importante reconhecer o papel crucial dos ambientes habitacionais e urbanos para a gestão de todos os tipos de recursos.

Quando se fala em qualidade das habitações, Palhares (2001) considera que "as propostas priorizam as qualidades técnico-construtivas, arquitetônicas e urbanísticas das moradias e dos assentamentos". O autor faz uma crítica aos projetos habitacionais que adotam critérios puramente econômicos para determinar a racionalidade dos espaços, resultando em uma redução excessiva das dimensões dos cômodos, comprometendo sua funcionalidade e forçando os moradores a fazer diversas modificações. Segundo este autor, apesar de ser inquestionável a necessidade de se oferecer moradia a todos, a insatisfação demonstrada pelos moradores confirma a necessidade de também serem avaliados os aspectos qualitativos das unidades e dos assentamentos habitacionais.

Roméro e Ornstein (2003) apresentam algumas razões para explicar o porquê de os padrões de qualidade das unidades habitacionais e dos assentamentos não serem atingidos. As principais explicações dadas pelos autores referem-se à utilização de materiais de baixo custo, o que tem levado a uma rápida deterioração das obras, à ausência de manutenção da qualidade e à inexistência ou precariedade da infraestrutura, embora haja leis específicas que determinam a sua obrigatoriedade. Os autores salientam, ainda, a existência de deficiências no processo de fiscalização da construção adotado pelas políticas públicas de apoio financeiro aos mutuários, que deveria ser mais rigoroso para evitar que materiais sejam alterados e para garantir que os procedimentos sejam realizados de forma correta. Eles defendem, ainda, que a baixa qualidade da mão de obra implica em percentuais ainda mais elevados de falhas na etapa de execução.

Considerando-se todas essas questões, fica claro que o processo de criação e produção de habitações para a população de baixa renda precisa ser revisto, sendo necessárias mudanças na cultura e práticas do processo, além do desenvolvimento de instrumentos de apoio, defendem Bonatto et al. (2011). 
Já Palhares (2001) defende que essa revisão deve ser fundamentada na avaliação crítica das experiências já consolidadas, que deve ser realizada com base na discussão das hipóteses adotadas pelos arquitetos na etapa de concepção do projeto e nas diretrizes de produção estabelecidas pelas políticas habitacionais já implantadas.

Segundo Penzim (2001 apud PALHARES, 2001), a ação de morar é influenciada por diversos fatores de ordem histórica, cultural, social, demográfica, psicológica, política, econômica, ética e estética que se inter-relacionam. Assim, ele defende que "é ao longo da ocupação das unidades que percebemos se os espaços das habitações têm sido capazes de atender minimamente às necessidades dos moradores".

A satisfação residencial pode ser definida como o sentimento de contentamento quando se tem ou se consegue o atendimento às necessidades ou desejos da família em uma casa, afirmam Mohit et al. (2010).

Mohit et al. (2010) acreditam que a satisfação com a habitação popular de baixo custo é determinada por níveis de percepção dos entrevistados com características objetivas, como as características da unidade habitacional, serviços de apoio das unidades, equipamentos públicos, o ambiente social e elementos do bairro, tais como o nível de criminalidade, a quantidade e qualidade dos espaços de lazer ou a falta de postos de trabalho também podem influenciar na satisfação com a habitação.

De acordo com Liu (1999), um baixo nível de satisfação residencial pode resultar na mudança para outra moradia ou, nos casos em que tal não seja possível, a adaptação da habitação às novas necessidades que possam surgir, como, por exemplo, a realização de melhorias na casa.

Mohit et al. (2010) corroboram com essa opinião e afirmam que o não atendimento a estas necessidades e aspirações pode levar à insatisfação, resultando na migração da família para uma moradia que atenda aos seus anseios ou no que os autores chamam de remodelação da moradia existente. Nos dois casos, os autores afirmam que as famílias devem ter informações suficientes sobre as oportunidades de adaptação alternativas e recursos financeiros condizentes.

Portanto, conforme defendem Moraes e Santana (2004), é de fundamental importância a opinião do usuário na avaliação da qualidade das habitações. Os 
autores lembram, entretanto, que a satisfação do usuário depende, além da vivência e aspirações, da situação atual em que ele se encontra, ou seja, a satisfação também varia com o tempo, podendo o momento da avaliação influenciar em sua opinião. Da mesma forma, Mohit et al. (2010) afirmam que as famílias costumam fazer seus julgamentos sobre as condições de habitação com base em suas necessidades e aspirações, que podem mudar ao longo do seu ciclo de vida.

Mohit et al. (2010) acreditam que a satisfação residencial é um indicador importante que pode ser utilizado por projetistas, arquitetos e formuladores de políticas como um indicador de percepção da qualidade de vida dos usuários e da mobilidade habitacional e como ferramenta de avaliação do sucesso dos empreendimentos construídos pelos setores público e privado e das percepções dos moradores de inadequações em seu ambiente de moradia atual.

De acordo com Lawrence (1995), uma das principais funções das edificações é fornecer proteção contra as exigências e os perigos do "ambiente externo", por isso, é pertinente avaliar a eficácia das unidades habitacionais nesta função, garantindo também que esta proteção contra perigos externos não será contrabalançada por perigos internos não previstos.

Diversos pesquisadores, como citam Bonatto et al. (2011), concordam que a etapa de uso dos empreendimentos é a mais propícia em aprendizagem sobre como atingir uma maior satisfação do consumidor. Assim, as avaliações se tornam uma possibilidade para visualização de resultados diante dos objetivos de ações realizadas e permitem que se possa aprender e retroalimentar futuros projetos, sempre visando à melhoria.

Varady e Carrozza (2000 apud MOHIT et al., 2010) afirmam que a medida da qualidade da habitação tornou-se uma ferramenta importante para os governos como forma de garantir que as famílias estejam satisfeitas com a habitação e os serviços fornecidos.

Segundo Liu (1999), existem diferentes abordagens de avaliação:

- Abordagem global para descobrir fatores, nos níveis físicos e sociais, que afetam a satisfação dos moradores de habitação.

- Desenvolvimento de critérios de desempenho e ferramentas de classificação. 
- Relação de satisfação residencial com o risco de acidentes infantis, a densidade espacial, a aglomeração e as características da vizinhança.

- Avaliação da qualidade do projeto de construção, em termos de função e custo.

De acordo com este autor, dependendo da abordagem adotada para satisfazer um propósito particular de investigação, a avaliação pode ser feita durante a fase de projeto ou após a conclusão da construção através de avaliações pósocupação.

Zimring e Reizenstein (1980 apud MARMOT, 1983) definem a avaliação pósocupação como "a análise da eficácia para os usuários humanos dos ambientes projetados ocupados".

Já de acordo com Ornstein e Romero (1992 apud MORAES; SANTANA, 2004), a "avaliação pós-ocupação é uma área de conhecimento que combina avaliação técnica e o ponto de vista do usuário, pretendendo se configurar como uma avaliação global do meio a ser estudado". Segundo os autores, as variáveis a serem analisadas podem ser complementadas, reduzidas e/ou alteradas, de acordo com a tipologia das edificações e com as características e objetivos da pesquisa.

Em um trabalho mais recente, os mesmos autores declaram que:

"a APO diz respeito a uma série de métodos e técnicas que diagnosticam fatores positivos e negativos do ambiente no decorrer do uso, a partir da análise de fatores socioeconômicos, de infraestrutura e superestrutura urbanas dos sistemas construtivos, conforto ambiental, conservação de energia, fatores estéticos, funcionais e comportamentais, levando em consideração o ponto de vista dos próprios avaliadores, projetistas e clientes, e também dos usuários" (ROMERO; ORNSTEIN, 2003).

Marmot (1983) afirma, que, embora seja difícil comparar as pessoas em diferentes configurações de ambientes, um requisito essencial de toda APO é informar sobre as características demográficas e sócio-econômicas das populações estudadas, suas razões para mover-se, o porquê de terem escolhido as suas habitações e quanto tempo residem nelas.

Lawrence (1995) destaca, ainda, como um grande problema o fato de a avaliação sistemática não ser considerada uma responsabilidade dos administradores públicos, agentes da política habitacional e projetistas, o que 
poderia ser superado a partir do compromisso de todos no acompanhamento de longo prazo dos programas e empreendimentos habitacionais.

Para Roméro e Ornstein (2003), a APO se distingue das "clássicas" avaliações de desempenho realizadas pelos institutos de pesquisa porque tem como objetivo fundamental também aferir o atendimento das necessidades ou o nível de satisfação dos usuários, sem, no entanto, minimizar a importância da avaliação de desempenho físico ou "clássica". Nesse sentido, os autores defendem que "a APO tem grande validade 'ecológica', pois faz análises, diagnósticos e recomendações a partir dos objetos de uso, in loco, na escala e tempo reais".

De acordo com Marmot (1983), a longo prazo a APO é necessária para ajudar a construir a nossa compreensão sobre o desempenho das habitações 'diferentes' e as interconexões entre a forma de habitação, os diferentes grupos de moradores e as regras de manutenção e gestão, enriquecendo o nosso conhecimento sobre o ambiente construído. Assim, o autor acredita que, munidos de uma base de conhecimento mais sólida, os projetistas terão mais capacidade de prever as consequências das formas de habitação já testadas e, possivelmente, ficarão mais satisfeitos em repetir soluções bem sucedidas ao longo de muitas avaliações.

A APO resulta no levantamento de fatores positivos e negativos, sendo importante o registro de ambos, lembram Roméro e Ornstein (2003). Segundo os autores, os fatores positivos devem ser cadastrados e recomendados para futuros projetos semelhantes. Já os fatores negativos devem gerar recomendações que minimizem ou possibilitem a correção dos problemas detectados no ambiente construído avaliado e que sirvam para retroalimentar o processo de produção e uso de ambientes de futuros projetos com a formulação de diretrizes, contribuições para normas existentes e outros.

Roméro e Ornstein (2003) defendem que o levantamento, a análise e as recomendações extraídas das avaliações de desempenho físico e satisfação do usuário visam realimentar o próprio estudo de caso, bem como futuros projetos, constituindo-se em um instrumental de controle de qualidade que pode ser colocado em prática por meio das metodologias de APO. A figura 1 apresenta o posicionamento da APO, enquanto mecanismo de retroalimentação, dentro do ciclo de execução das habitações: 


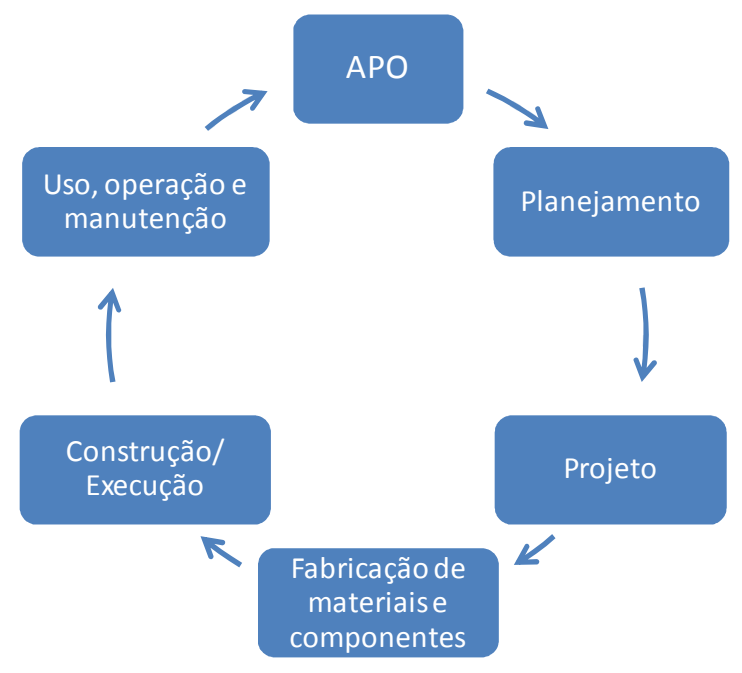

Figura 1 - Ciclo de execução das habitações incluindo a APO Fonte: adaptado de ROMERO; ORNSTEIN, 2003.

Liu (1999) afirma que o benefício a curto prazo do processo de APO é a contribuição para resolver problemas imediatos no empreendimento analisado e o benefício a médio prazo é a contribuição para o próximo ciclo de construção, ou seja, para outros empreendimentos. De acordo com o autor, esta avaliação só tem valor se for parte de algum processo de manutenção constante de equilíbrio entre os ocupantes e o meio ambiente.

Roméro e Ornstein (2003) apontam alguns aspectos que podem ser melhorados através dos processos de APO, como seguem:

- as normas descritivas são muito mais conhecidas do que as normas de desempenho de edifícios;

- há poucas normas relativas às avaliações e perícias;

- elaboração do Manual do Usuário para edificações;

- pouca utilização do Código de Defesa do Consumidor e do Manual do Profissional elaborado pelo Conselho Regional de Engenharia e Agronomia (CREA);

- rara adoção da NBR 9050/05 - Acessibilidade de Pessoas Portadoras de Deficiências a Edificações, Espaços, Mobiliário e Equipamentos Urbanos em empreendimentos de habitação de interesse social.

Segundo Bonatto et al. (2011), os empreendimentos habitacionais de interesse social (EHIS) têm sido alvo de diversos estudos realizados no meio 
acadêmico e a busca de melhores resultados em relação a esses empreendimentos gera benefícios aos seus usuários e melhorias para a sociedade, uma vez que os EHIS têm importantes implicações no desenvolvimento das cidades e na qualidade de vida que elas proporcionam aos seus cidadãos. No entanto, os autores destacam que, para que haja os benefícios para a sociedade, são necessários bons resultados na relação entre o usuário e $\mathrm{o}$ produto oferecido no âmbito dos programas habitacionais pelos diferentes agentes envolvidos. Assim, considerando os recursos investidos em programas habitacionais, eles salientam a importância da formação da satisfação e da geração de valor para a população atendida, a fim de que realmente esses benefícios ocorram de forma duradoura.

Verifica-se, portanto, a necessidade e a importância dos processos de avaliação pós-ocupação (APO), que, através de uma série de métodos e processos bem definidos, visa avaliar as edificações com base em critérios técnicos e na satisfação dos usuários.

\subsection{Histórico}

Com base nos conceitos apresentados no item anterior, iniciam-se, na década de 60 , de forma sistemática, as pesquisas sobre o desempenho físico dos ambientes voltadas para a qualidade destes, ou seja, para o atendimento às necessidades dos usuários. Roméro e Ornstein (2003) destacam, em seu trabalho, alguns estudos historicamente importantes nesta área:

- a atuação de Gerard Blachère, que publica em 1966 a obra "Savoir-BatirHabitabilité-Durabilité-Economie des Bâtiments" (Editions Eyrolles) junto ao Centre Scientifique et Technique du Bâtiment (CSTB) ;

- a obra de BOUDON (1972), intitulada "Lived in Architecture", que avalia o conjunto habitacional Pessac, próximo a Bordeaux, França, projetado por Corbusier na década de 20;

- a fundação, em 1967, do Building Performance Research Unit (BPRU), na Grã-Bretanha, que objetivava o desenvolvimento sistemático de procedimentos empíricos para a avaliação de edifícios como parte integrante do processo projetual;

- a obra de David Canter, que em 1970 publica "Architectural Psychology". 
Ainda segundo esses autores, os estudos voltados às Relações Ambiente \& Comportamento (RAC) na Europa estão abrigados na International Association for People - Environment Studies (IAPS). Nos EUA, a APO e os estudos das RAC's começam a se consolidar, em especial, a partir da fundação da Environmental Design Research Association (EDRA), em 1969, que passa a congregar pesquisadores de campos distintos, buscando o desenvolvimento de projetos conjuntos e interdisciplinares. Entre os pesquisadores dessa associação, podem ser destacados Robert B. Bechtel, Richard Wener, Wolfgang F. E. Preiser, Christopher Alexander, Claire Cooper Marcus, Amos Rapoport, Robert Sommer e Denise Lawrence. Destaca-se que ocorreu, no caso dos Estados Unidos, um boom das avaliações dos programas sociais, e até 1978 Bechtel e Srivastrava contabilizaram mais de 1.500 APO's aplicadas em conjuntos habitacionais.

No campo internacional, segundo Roméro e Ornstein (2003), "os multimétodos de APO vêm sendo adotados por psicólogos ambientais norteamericanos há mais de 40 anos", visando aferir em que medida o desempenho dos ambientes influencia o comportamento humano e vice-versa. Tanto na Europa como nos Estados Unidos, a partir do Pós-Guerra, sobretudo a partir da década de 60, equipes interdisciplinares constituídas por arquitetos, engenheiros, geógrafos, paisagistas, antropólogos, psicólogos e outros começam a avaliar os resultados da arquitetura moderna de "massa", especialmente no caso dos grandes conjuntos habitacionais. Além dos aspectos específicos do desempenho físico das edificações, iniciam-se os estudos sobre padrões culturais, privacidade, territorialidade, personalização, apropriação, segurança e faixa etária com ênfase no usuário dos ambientes.

No Brasil, a política habitacional adotada pelo governo a partir dos anos 30 , e intensificada nas décadas de 60 e 70, produziu uma série de conjuntos habitacionais para a população de baixa renda. Entretanto, a baixa qualidade dessas habitações atraiu o olhar dos pesquisadores para essa realidade e desencadeou a realização de pesquisas de avaliação no país.

Para Malard et al. (2002), "produzir unidades e assentamentos habitacionais populares de baixo custo e de boa qualidade é um problema sobre o qual muitos pesquisadores brasileiros se têm debruçado desde os anos 60". 
Roméro e Ornstein (2003) expõem a necessidade de se avaliar a situação desses conjuntos habitacionais na realidade atual, seu impacto em termos de habitação social irradiando nas vizinhanças e na cidade, a satisfação de seus usuários e as eventuais demandas latentes. Segundo os autores, na condição de assentamento humano, o conjunto precisa oferecer condições de qualidade com as quais a população possa cultivar e melhorar sua cultura urbana, ou seja, "seus hábitos de viver em comunidade, exercendo seus direitos e respeitando os do próximo".

Portanto, desde a década de 60, conforme relatam Romero e Ornstein (2003), começa-se a verificar a relevância da aplicação da Avaliação Pós-ocupação (APO) como mecanismo de retroalimentação de processos de controle de qualidade e desenvolvimento de projetos complexos voltados às populações especiais (ex.: aeroportos, shopping centers, hospitais e parques) e/ou implantados em larga escala e repetitivamente (ex.: conjuntos habitacionais, escolas, postos de saúde).

No Brasil, no período de 1972 a 1987, Roméro e Ornstein (2003) destacam o desenvolvimento de pesquisas na linha da APO realizadas no Instituto de Pesquisas Tecnológicas (IPT) do Estado de São Paulo e, mais recentemente, por grupos emergentes, tais como aqueles existentes na Faculdade de Arquitetura e Urbanismo; no Núcleo de Pesquisa em Tecnologia da Arquitetura e Urbanismo da Universidade de São Paulo (NUTAU/USP); no Núcleo Orientado para a Inovação da Edificação (NORIE), da Universidade Federal do Rio Grande do Sul; na Faculdade de Arquitetura e Urbanismo da Universidade Federal de Pernambuco; no Grupo de Estudos Pessoa-Ambiente (GEPA), da Universidade Federal do Rio Grande do Norte; na Faculdade de Arquitetura e Urbanismo da Universidade Federal do Rio de Janeiro; e no Laboratório de Psicologia Ambiental da Universidade de Brasília, além de algumas atividades nesse campo realizadas pela empresa particular Centro de Tecnologia de Edificações (CTE), com sede na cidade de São Paulo.

Roméro e Ornstein (2003) relatam, ainda, que entre o final da década de 90 e início dos anos 2000 houve um aumento considerável no número de estudos sobre qualidade da construção, principalmente aqueles relacionados à Gestão da Qualidade e à ISO 9000, visando a redução dos custos de qualidade e dos custos das falhas durante a produção e uso. Essa tendência pode ser verificada ainda nos dias de hoje. 


\subsection{Tipos de avaliação pós-ocupação}

Roméro e Ornstein (2003) classificam, em sua pesquisa, subáreas de avaliação, o que, segundo os autores, auxilia no tratamento das diversas variáveis e da complexidade encontrada, bem como no desenvolvimento e aperfeiçoamento de métodos e técnicas específicos para os problemas de cada subárea.

As subáreas de APO apresentadas por esses autores são descritas a seguir:

\subsubsection{Avaliação dos aspectos funcionais}

Enfoca, em níveis distintos de profundidade, a avaliação funcional dos ambientes internos, alguns aspectos relevantes dos edifícios em seu conjunto, passando pela avaliação das áreas externas, coletivas, e/ou condominiais até a análise de aspectos das áreas livres e do desenho urbano do conjunto habitacional, afirmam Roméro e Ornstein (2003). Segundo os autores, ainda são relativamente reduzidos os estudos no Brasil que abordam a funcionalidade com detalhes, visando realimentar futuros projetos, sendo que os trabalhos já concluídos sugerem a necessidade de aprofundar e sistematizar esses dados.

\subsubsection{Avaliação dos aspectos construtivos}

Roméro e Ornstein (2003) definem a APO do sistema construtivo como "uma avaliação técnica vinculada às patologias construtivas existentes nos edifícios". Os autores utilizam, como metodologia para essa APO, a abordagem dos dez órgãos básicos constituintes do edifício, academicamente adotada pelos pesquisadores do grupo de disciplinas da "Tecnologia da Construção" da Faculdade de Arquitetura e Urbanismo da Universidade de São Paulo (FAU/USP). Segundo essa abordagem, os dez órgãos básicos constituintes do edifício são: terrapleno, fundação, estrutura, cobertura, vedos, vãos, paramentos, pavimentos, instalações hidrossanitárias e eletromecânicas, complementadas pela infraestrutura urbana e por equipamentos complementares.

\subsubsection{Avaliação do conforto ambiental}

Em sua pesquisa, Roméro e Ornstein (2003), subdividem os estudos relativos ao conforto ambiental em cinco grandes áreas ou disciplinas com especificidades 
distintas, denominadas de "subáreas", a saber: Iluminação Natural, Insolação, Conforto Higrotérmico, Ventilação Natural e Acústica. Segundo os autores, todas as subáreas do Conforto Ambiental dependem de uma multiplicidade de variáveis, que vão de um plano muito geral a um muito específico e que poderiam ser divididas em três grandes classes:

a) variáveis climáticas e do entorno à edificação;

b) variáveis relativas às exigências humanas e funcionais; e

c) variáveis de projeto e construtivas.

\subsubsection{Avaliação econômica}

Para Roméro e Ornstein (2003), "a habitação popular e econômica é um grande desafio tanto para a arquitetura como para a engenharia de custos". A necessidade de se obter o máximo de eficiência com o mínimo de investimento de dinheiro, tempo e espaço tem servido como justificativa para a adoção de soluções de projeto e construtivas que atendem apenas minimamente às necessidades $e$ expectativas dos moradores. Assim, não são considerados problemas com o uso, manutenção e substituição precoce de seus elementos, que trazem um aumento de custo justamente na etapa de uso das habitações, quando é o morador quem deve manter a edificação. Segundo os autores, o objetivo desta "avaliação econômica", que também é funcional, é o de apontar algumas direções de solução que, acreditase, sejam absolutamente mínimas e necessárias para promover a habitação popular a estágios suficientes de satisfação dos seus moradores.

\subsection{Métodos e técnicas de avaliação pós-ocupação}

Roméro e Ornstein (2003) afirmam que "a APO é um conjunto de métodos e técnicas que são utilizados e combinados de acordo com os objetivos de cada pesquisa e também dos recursos humanos e financeiros envolvidos". Segundo os autores, o cruzamento desses procedimentos, os diagnósticos e os produtos resultantes podem gerar recomendações, bancos de dados, vídeo e relatórios.

Ao longo dos anos, diversos métodos e técnicas têm sido desenvolvidos para a realização dos diversos tipos de APO, constituindo-se em um extenso "menu" de 
opções para os pesquisadores que pretendem realizar estudos de avaliação pósocupação.

Conforme lembram Roméro e Ornstein (2003), a aplicação de métodos e técnicas de APO deve levar sempre em consideração o ponto de vista dos técnicos (vistorias, medições e análises realizadas) e a aferição dos níveis de satisfação dos usuários.

Villa (2009) destaca, ainda, cinco questões fundamentais que devem ser consideradas em avaliações de espaços habitacionais:

1. Por se tratar de uma abordagem privada, necessita de procedimentos específicos e cautelosos de pesquisa para que os moradores não se sintam invadidos em sua privacidade e aceitem participar do processo.

2. É preciso garantir aos moradores sigilo nas informações obtidas.

3. É preciso saber lidar com aqueles entrevistados que se sentem acanhados em responder questões íntimas ou privadas.

4. Em virtude dos altos índices de violência que se verificam atualmente, alguns moradores podem ficar receosos em participar de pesquisas.

5. Os moradores nem sempre têm disponibilidade de tempo para responder a questionários e entrevistas ou participar de reuniões em grupo.

Durante a realização da revisão bibliográfica, foi possível levantar os principais métodos e técnicas de APO, conforme descritos a seguir:

\section{Medidas para aferição do desempenho físico}

Trata-se de um conjunto de medidas referentes à iluminação, acústica, temperaturas, dimensões, correntes elétricas e tensões. Elas podem confirmar ou não os pontos de vista dos usuários e as leituras de projeto, entretanto, deve-se atentar para a interpretação dos resultados, calibração dos equipamentos e cuidados na tabulação dos dados (ROMÉRO; ORNSTEIN, 2003).

\section{Entrevista}

É um instrumento muito utilizado em diversas áreas e, segundo Rheingantz et al. (2009), pode ser definida como "um relato verbal ou uma conversação 
voltada para atender a um determinado objetivo, que resulta em um conjunto de informações sobre os sentimentos, crenças, pensamentos e expectativas das pessoas". Proporcionam rapidez e confiabilidade, entretanto, necessitam de um prazo maior de aplicação. O seu sucesso depende muito da qualificação e da competência dos pesquisadores, além de sua sensibilidade e capacidade de interação com o respondente. As entrevistas podem ser estruturadas, quando seguem um roteiro pré-definido, semiestruturadas, quando seguem um roteiro básico, ou não estruturas, quando não seguem nenhum tipo de padronização das questões (RHEINGANTZ et al., 2009; ROMÉRO; ORNSTEIN, 2003).

\section{Questionário}

É um instrumento muito utilizado em avaliações de desempenho e de grande utilidade quando se necessita obter informações sobre comportamentos, atributos e atitudes de usuários e descobrir regularidades entre grupos de pessoas por meio da comparação de respostas. Podem ser organizados por categoria de usuário e possibilitam rápida aplicação e tabulação, com resultados muito confiáveis se a quantidade de questionários tiver sido estatisticamente calculada. As perguntas devem ser respondidas por escrito sem a presença do pesquisador e não é recomendada a aplicação para amostras inferiores a 30 pessoas. (RHEINGANTZ et al., 2009; ROMÉRO; ORNSTEIN, 2003).

\section{Mapa comportamental}

Concebido por Ross Thorne e J. A. Turnbull, possibilita identificar a percepção dos usuários em relação a um determinado ambiente, constituindo-se em registros físicos das atividades realizadas de modo repetitivo e sistemático por unidade de espaço, no decorrer de períodos pré-determinados. Podem ser aplicados em ambientes internos e externos. Fornecem um retrato dos comportamentos dos usuários e suas frequências, necessitando, por vezes, de uma permanência prolongada dos pesquisadores no local analisado (RHEINGANTZ et al., 2009; ROMÉRO; ORNSTEIN, 2003). 


\section{Registros fotográficos}

Permitem avaliações posteriores e são úteis nas avaliações de comportamento físico, comportamento dos usuários e mapas comportamentais. Apresentam baixo custo, rapidez e confiabilidade no registro, sendo uma técnica complementar às demais (ROMÉRO; ORNSTEIN, 2003).

\section{Registros em áudio vídeo}

Permitem o registro sonoro de ruídos urbanos e de ruídos entre unidades habitacionais. Permitem documentar comportamentos com precisão muito maior do que a técnica de registro fotográfico, entretanto, seu custo é mais alto. Também documentam outras técnicas de APO, tais como a realização dos grupos focais, as entrevistas específicas e outros métodos e técnicas utilizados na pesquisa. Os vídeos são úteis e versáteis, permitindo a produção de um banco de dados de imagens para posterior análise por técnicos e especialistas. É uma técnica complementar às demais (ROMÉRO; ORNSTEIN, 2003).

\section{Grupo focal}

É um método de pesquisa e avaliação utilizado para fornecer dados qualitativos para complementar dados quantitativos obtidos por meio de outros métodos. Esse método propõe discussões informais, porém organizadas sobre um tema específico de integração. Necessitam de um moderador que formula as questões e conduz a discussão para uma conversa informal e de um assistente para registrar as informações. Os grupos focais devem ter entre 6 e 12 participantes (ROMÉRO; ORNSTEIN, 2003; VILLA, 2009).

\section{Walkthrough}

Método originário da Psicologia Ambiental, consiste em uma caminhada pelos ambientes em análise, onde o pesquisador conversa com os usuários e analisa suas reações em relação ao ambiente, complementando as informações com fotografias, croquis gerais e gravações de áudio e de vídeo. 
Criado por Kevin Lynch, é um instrumento muito útil na APO e na programação arquitetônica, pois possibilita a familiarização do pesquisador em relação ao ambiente. Apresenta baixo custo e rapidez, sendo ideal para casos em que o cronograma de execução da pesquisa é curto e a equipe é pequena (RHEINGANTZ et al., 2009; ROMÉRO; ORNSTEIN, 2003; VILLA, 2009).

\section{Poema dos desejos}

O poema dos desejos, ou wish poem, foi desenvolvido por Henry Sanoff e consiste na declaração das necessidades, sentimentos e desejos dos usuários de um determinado ambiente através de um texto ou de desenhos. Baseia-se na espontaneidade das respostas e tem fácil elaboração e aplicação, produzindo, de um modo geral, resultados ricos e representativos das demandas e expectativas dos usuários (RHEINGANTZ et al., 2009 ).

\section{Mapa mental ou Mapeamento cognitivo}

Desenvolvido por Kevin Lynch nos anos 50, consiste na elaboração de desenhos ou relatos de memória representativos das ideias e sentimentos que uma pessoa ou um grupo de pessoas tem de um determinado ambiente. Pode incorporar experiências pessoais ou experiências relatadas por outras pessoas, pela imprensa falada e escrita ou pela literatura (RHEINGANTZ et al., 2009 ).

\section{Seleção visual ou Visual crues}

Método desenvolvido por Henry Sanoff e adequado para identificar ideias, valores, atitudes e significados agregados pelos usuários aos ambientes analisados. Consiste em apresentar um conjunto de imagens referenciais préselecionadas, permitindo incentivar também a análise crítica de um ambiente pelos seus usuários. Possibilita avaliar o impacto causado por determinadas tipologias arquitetônicas, organizações espaciais, cores e texturas sobre a qualidade de vida e o bem-estar das pessoas (RHEINGANTZ et al., 2009; VILLA, 2009). 


\section{Tarjeta reflexiva}

Adotado por Villa (2009), este método é uma adaptação do método das constelações de atributos. Consiste na indicação, por parte dos moradores, de uma qualidade ou adjetivo para sua moradia e, posteriormente, a característica principal que uma moradia deveria ter. Monta-se, então, um mural com todas as respostas e os usuários são convidados a comentar suas respostas, gerando discussões e reflexões das quais os pesquisadores podem retirar informações valiosas.

\section{Brincando de boneca}

Apresentada por Villa (2009), essa técnica busca substituir o instrumento "Poema dos Desejos". Com base em um modelo físico (ou maquete) os usuários são chamados a falar sobre sua moradia. Seu principal objetivo é identificar os desejos dos moradores participantes, seus sonhos e expectativas em relação à sua moradia.

\section{Análise do uso (AU)}

Trata-se de uma análise funcional mais específica relativa aos espaços privados e a forma de uso destes pelos usuários. Os objetivos principais dessa análise são: identificar atividades realizadas nos respectivos cômodos, a presença de sobreposição de atividades e dos níveis de conforto e a observação da relação entre atividades e mobiliário e o espaço utilizado para o atendimento delas (VILLA, 2009).

\section{Checklist técnico ou Roteiro técnico}

Trata-se de um roteiro de atividades utilizado, principalmente, para orientar as primeiras vistorias realizadas pelos técnicos, evitando falhas e discrepâncias na coleta de informações (ROMÉRO; ORNSTEIN, 2003).

\section{Matriz de descobertas}

Concebido por Helena Rodrigues e Isabelle Soares, é um instrumento de análise que permite identificar e comunicar graficamente as descobertas relacionadas com as adaptações e improvisações na habitação, assim como 
aquelas relacionas à incompreensão e ao desconhecimento dos diversos grupos de usuários, que dificultam a operacionalidade necessária no dia a dia de um ambiente. Consiste em um resumo gráfico das principais descobertas de uma avaliação de desempenho, facilitando a leitura e a compreensão dos resultados (RHEINGANTZ et al., 2009).

\section{Matriz de recomendações}

É um desdobramento da Matriz de Descobertas e apresenta as recomendações decorrentes dessas descobertas, hierarquizadas em função do prazo de intervenção (curto e médio prazo) e pelo grau de importância e/ou urgência de execução (RHEINGANTZ et al., 2009 ).

Diante de todos os métodos e técnicas apresentados aqui, é possível perceber que a APO conta com um elevado número de instrumentos de apoio, cabendo, portanto, aos pesquisadores, a definição daqueles mais adequados para cada situação. 


\section{MODIFICAÇÕES REALIZADAS PELOS MORADORES EM UNIDADES DE HIS}

Diante da complexa rede de relações entre os vários agentes participantes da provisão habitacional e o Estado citada por Werna et al. (2001), Lima et al. (2011) afirmam que o gerenciamento de requisitos dos clientes adquire importância para lidar com os conflitos entre esses requisitos, as pressões para redução de prazos e o gerenciamento do processo de tomada de decisão.

Apesar disso, Roméro e Ornstein (2003) acreditam que as habitações destinadas à população de baixa renda, independentemente do agente promotor, dos mecanismos de produção e das formas de acesso à moradia, continuam necessitando de realizações concretas que levem a melhorias do desempenho funcional visando o atendimento às necessidades dos moradores e à satisfação destes no contexto da qualidade de vida urbana.

Barlow e Ozaki (2003 apud LIMA et al., 2011) afirmam que os clientes finais desse setor vêm tornando-se cada vez mais bem informados, mais exigentes e menos tolerantes aos serviços precários e aos defeitos construtivos, demandando maior atenção a informações relacionadas às necessidades e expectativas do cliente final para superar os problemas básicos de qualidade do setor habitacional.

Além disso, segundo Tramontano (1993; 2000 apud PALHARES, 2001), as características das famílias vêm se alterando profundamente nas últimas décadas, tanto com relação ao tamanho quanto em relação à estrutura e à sua própria função. Há algumas décadas, existe uma tendência crescente à composição de novos grupos domésticos, diferentes da família nuclear tradicional, com mudanças nas relações entre seus membros.

Para Palhares (2001), o processo de criação e produção das habitações para população de baixa renda demanda interação entre grande grupo de profissionais, que irão compor uma equipe multidisciplinar. De acordo com o autor, cabe a estes profissionais estar atentos a todas as modificações e transformações, cada dia mais rápidas e intensas, pelas quais passa a sociedade e que alimentarão as reflexões na proposição dos espaços da habitação, pois "as variações demandarão espaços em quantidade e dimensões diferenciados, que não podem ser desconsiderados", o que leva à necessidade de uma nova reflexão sobre os espaços. 
Quando não há harmonia na relação ambiente-usuário, a tendência natural é que o usuário modifique o ambiente, adaptando-o à sua proposta (MEIRA; SANTOS, 1998 apud MARROQUIM; BARBIRATO, 2007). Palhares (2001) afirma, ainda, que as variadas formas de ocupação e uso dos espaços por parte dos diferentes grupos provocam modificações que são empreendidas pelos moradores nas unidades habitacionais ao longo da ocupação.

Van Gelder (2007) destaca, ainda, a segurança de posse da habitação como um fator determinante da realização dessas modificações. Essa segurança de posse pode ser dada pela existência de um título legal ou pela segurança percebida da posse obtida através de uma declaração oficial ou um acordo de que não haverá remoção das famílias, pela prestação de serviços públicos ou pela emissão de certificados de uso, afirma o autor.

Ainda de acordo com Van Gelder (2007), a segurança percebida de posse é uma variável psicológica que está relacionada com a melhoria da habitação em assentamentos informais, pois o medo do despejo é o fator determinante da realização ou não da melhoria habitacional nessas situações.

Por outro lado, de acordo com Gilbert (1994 apud VAN GELDER, 2007), quando as pessoas estão confiantes de que não serão removidas pelas autoridades, elas seguem a tendência natural de melhorar as suas habitações. Assim, quando as famílias de baixa renda passam de um assentamento informal para um empreendimento de HIS, essa segurança de posse fica quase que totalmente garantida, dependendo apenas da quitação das pequenas parcelas de pagamento impostas pelos programas habitacionais voltados a essa população, e as modificações são realizadas com mais confiança por parte dos moradores.

Diversos autores confirmam que são frequentes as alterações realizadas por moradores nas unidades habitacionais de Habitações de Interesse Social (HIS) construídas no Brasil (PALHARES, 2001; MARROQUIM; BARBIRATO, 2007, BRANDÃO, 2011).

As razões pelas quais o usuário deseja promover alterações em sua habitação são várias, sendo forte a ligação com fatores simbólicos e estéticos, afirma Brandão (2011). Estas alterações podem ser positivas ou negativas e podem também refletir mudanças sociais e comportamentais dos usuários (padrão de vida 
dos usuários, mudanças de mentalidade, mudanças simbólicas, nível educacional, cultural etc.).

Para Marroquim e Barbirato (2007), essas modificações são realizadas, entre outros aspectos, por motivos de caráter funcional, simbólico ou econômico e "quase sempre evidenciam a falta de sintonia entre o projeto arquitetônico original e as respostas às necessidades de seus usuários".

Segundo Palhares (2001), estas modificações visam, sobretudo, "adequar o uso de tais habitações às ilimitadas necessidades dos moradores, sujeitas a variada gama de valores que as ampliam além das condições mínimas preestabelecidas". Assim, a organização de usos dos espaços e das atividades é redefinida ao longo da ocupação.

Reis (1995 apud BRANDÃO, 2011), descreve mais detalhadamente estas alterações, relacionando-as a: aspectos funcionais, como disposição e tamanho das peças; tamanho da moradia; aspectos ligados à privacidade visual e auditiva; aspectos ligados a questões estéticas; aspectos ligados a questões de personalização e definição do território; alterações no tamanho da família, nível econômico e educacional, dentre outros.

Brandão (2011) complementa relatando que essas modificações não seguem uma regra geral, dependendo da maior ou menor adequação do projeto original, porém, segundo o autor, ampliações de cozinhas e criação de novas dependências, como dormitórios e edículas, são frequentes.

Buscando conhecer as diversas modificações realizadas pelos moradores e identificar os códigos de uso que as geraram, Palhares (2001) apresenta uma classificação das modificações segundo o tipo de intervenção físico-espacialtecnológica realizada, que chama de Variantes de Modificação. Em seu estudo, o autor divide essas variantes em três grupos principais, de abrangência geral quanto às especificidades das modificações levantadas em campo:

1. Físicas - Referem-se às modificações físicas dos arranjos e redimensionamentos espaciais internos e externos. Redefinem os limites da geometria construtiva do projeto original, pautados na racionalidade construtiva. Referem-se ainda à retirada ou ao acréscimo de elementos construtivos que alteram os aspectos técnicos e compositivos originais da obra. 
2. Novos Usos - Dizem respeito aos novos usos destinados aos espaços das unidades habitacionais. Resultam de solicitações particulares, em função de adequação a demandas diferenciadas, como variação na composição e renda familiar, aumento do conforto, funcionalidade, praticidade, etc.

3. Tecnologia dos Materiais - Dizem respeito às modificações que alteram a tecnologia construtiva, a partir da mudança dos materiais empregados, ou do acréscimo de novos materiais.

Outro aspecto importante do estudo de Palhares (2001), é que as modificações inacabadas ou apenas desejadas também foram tabuladas, sendo caracterizadas como modificações pretendidas.

Meira e Santos (1998 apud MARROQUIM; BARBIRATO, 2007), acreditam, no entanto, que nem sempre é possível ao morador obter os resultados desejados, haja vista questões de ordem técnica, econômica e outras, acarretando-lhe prejuízos em diversos níveis.

Palhares (2001) afirma, ainda, que as modificações superam imposições de padrões, leis, normas técnicas e restrições econômicas, originalmente reguladoras do processo de criação e produção de tais unidades habitacionais. Já para Marroquim e Barbirato (2007), o principal problema constatado em relação a essas modificações é que na maioria dos casos elas impactam negativamente na funcionalidade e na habitabilidade dessas habitações, principalmente no que diz respeito ao conforto ambiental resultante.

Portanto, o resultado de tais modificações em relação aos projetos originais acaba provocando insatisfação geral, atingindo os agentes da política habitacional, os arquitetos e outros profissionais envolvidos no projeto e execução das unidades e, sobretudo, os próprios moradores (PALHARES, 2001).

Em muitos casos, os novos códigos de uso do espaço geradores ou gerados por essas modificações são estranhos ao arquiteto e aos agentes promotores da política habitacional, refletindo a necessidade de profunda investigação e análise crítica do que foi ofertado e de como está sendo realmente utilizado, defende Palhares (2001).

De acordo com Marroquim e Barbirato (2007), o estudo das modificações do espaço habitacional promovidas pelo usuário "permite compreender como os moradores dos conjuntos habitacionais se relacionam com a casa e qual o 
significado atribuído por eles aos espaços", mesmo que tecnicamente a solução utilizada seja inviável ou inadequada. Os autores defendem que o conhecimento dessas questões por parte dos projetistas pode auxiliá-los na elaboração de projetos de habitações flexíveis, que permitam ampliações e modificações sem diminuir o conforto ambiental e a qualidade espacial original da habitação, além de propiciar uma expansão condizente com as necessidades espaciais e culturais de seus moradores.

Palhares (2001) vai mais além e afirma que o conhecimento dos códigos de uso adotados pelos moradores é uma condição básica para o desenvolvimento dos projetos de arquitetura e urbanismo e para a gestão dos programas de habitação de interesse social.

Por sua vez, Reis (1995) afirma que "o conhecimento das necessidades de alterações nos leva a uma maior capacidade de produção de projetos habitacionais que estejam mais de acordo com as reais necessidades de seus usuários".

Assim, entende-se que o estudo das modificações pode ajudar a compreender também a relação entre essas modificações e os sistemas construtivos empregados na construção das casas, seja como fator gerador, facilitador ou dificultador da realização de tais modificações.

A bibliografia existente relata duas formas de se atuar visando a melhoria da qualidade dessas modificações, a flexibilidade de projeto, adotada ainda na concepção do empreendimento, e a assistência técnica para melhoria habitacional, que fornece auxílio técnico aos moradores para a realização das modificações. $A$ seguir serão apresentadas as duas propostas.

\subsection{Flexibilidade de projeto}

Segundo Rodwin (1987 apud ROMÉRO; ORNSTEIN, 2003), "as habitações sociais não vêm mais sendo consideradas como problemas, mas sim soluções extraordinariamente flexíveis e ajustáveis, o que representa uma mudança fundamental nessa área".

Diversos autores concordam que muitas decisões de projeto podem ser tomadas mais eficientemente pelo próprio usuário, pois é possível encontrar diferentes soluções para uma necessidade básica do homem em uma mesma cultura. (BRANDÃO; HEINECK, 2003 apud MARROQUIM; BARBIRATO, 2007). 
Nesse contexto, a construção de habitações de interesse social flexíveis é uma solução para minimizar os problemas citados no item anterior.

Till e Schneider (2005) definem a habitação flexível como aquela que pode adaptar-se às necessidades de mudança dos usuários, englobando tanto a possibilidade de escolha entre diferentes layouts antes da ocupação quanto a capacidade de ajuste da habitação ao longo do tempo.

A habitação flexível também pode ser definida como aquela que permite que seus moradores a adaptem aos seus desejos e necessidades sem grandes obras ou investimentos financeiros (SZÜCS, 1998a; DIGIACOMO; SZÜCS, 2003; DIGIACOMO, 2004 apud MARROQUIM; BARBIRATO, 2007).

De acordo com Galfertti (1997 apud BRANDÃO, 2011), flexibilidade é o grau de liberdade que torna possível a diversidade de modos de vida e consiste em um mecanismo efetivo para compensar a lacuna na conexão entre o arquiteto e o ocupante desconhecido.

Segundo Brandão (2011), a falta de flexibilidade de projeto é uma das causas de intervenções, demolição parcial e, até mesmo, a demolição completa de uma edificação. O autor lembra, ainda, que "a organização do espaço e o projeto devem ser compatíveis com diferentes padrões de vida no decorrer do tempo, ou seja, com multiplicidade de usos" e salienta que o conceito de habitação evolutiva exige previsão e projeção no projeto.

Till e Schneider (2005) citam seis princípios de flexibilidade que podem ser adotados como base para o projeto de habitações flexíveis. São eles:

1. Espaço: pouco espaço pode limitar a flexibilidade. Assim, alguns recentes projetos têm se empenhado em fornecer mais espaço, porém, sem uma definição de uso, deixando a cargo dos moradores a definição de como utilizá-lo;

2. Construção: técnicas de construção muito especializadas podem limitar a flexibilidade futura da habitação ao passo que exigem habilidades muito específicas para a realização de qualquer adaptação;

3. Projeto para adaptação: o projeto deve considerar a possibilidade de mudanças, sendo que o projetista deve visualizar as adaptações para o cenário futuro e pensar em como elas poderão ser realizadas; 
4. Camadas (layers): a identificação clara das camadas de construção (estrutura, vedações externas, instalações, divisórias internas e acabamentos) permite um melhor controle e flexibilidade destas camadas.

5. Plano típico: é possível desenvolver uma casca externa relativamente inflexível e um núcleo que concentre o acesso e as instalações, deixando o espaço entre eles indeterminado, com grandes vãos e planos abertos, permitindo a colocação e retirada de divisórias à vontade.

6. Instalações: a disposição das instalações deve ser cuidadosamente pensada para permitir futura mudança e modernização. Instalações verticais podem passar por dutos de fácil acesso e as horizontais podem passar sob pisos elevados ou sobre forros, permitindo infinitas possibilidades de disposição dos pontos de atendimento.

Em seu estudo, Till e Schneider (2005) propõem, ainda, uma classificação dos métodos pelos quais a flexibilidade pode ser alcançada em duas grandes categorias: utilização e tecnologia. A primeira se refere à forma como o projeto afeta a utilização da habitação ao longo do tempo e a segunda analisa ofertas de tecnologia de construção e manutenção e como elas afetam o potencial para a flexibilidade. Segundo os autores, cada uma dessas categorias apresenta técnicas denominadas suaves (soft flexibility) e rígidas (hard flexibility).

Segundo os autores, a utilização suave geralmente exige mais espaço e alguma redundância, mas permite que o usuário adapte o espaço de acordo com suas necessidades através da definição das divisões e usos dos ambientes, sendo que o projetista trabalha em segundo plano, apenas delimitando as unidades e posicionando as instalações. Já a utilização rígida geralmente é utilizada quando o espaço é limitado e deseja-se obter ambientes multifuncionais através de elementos mais específicos, como paredes corrediças e camas dobráveis, que determinam o modo como o espaço pode ser usado ao longo do tempo.

Outra forma de alcançar a flexibilidade na habitação é através da implantação de tecnologias, que podem englobar técnicas de construção, soluções estruturais, estratégias de manutenção ou uma combinação destes, podendo também ser divididas em suaves e rígidas, afirmam Till e Schneider (2005). Para estes autores, tecnologia suave é aquela que permite a flexibilidade da habitação sem ser 
totalmente controlada pelas técnicas de construção, utilizando, por exemplo, um sistema estrutural em grelha onde as divisórias internas não suportam cargas.

Já as tecnologias rígidas são definidas pelos autores como aquelas desenvolvidas especificamente para atingir a flexibilidade, sendo a característica determinante do projeto. Segundo os autores, a abordagem que tem sido mais sistematicamente adotada nessa linha é a da construção aberta, que nasceu dos estudos de John Habraken's. O princípio básico dessa abordagem é de que a habitação deve ser considerada como estrutura de suporte e enchimentos. A estrutura de suporte deve fornecer a infraestrutura básica e ser concebida como uma base permanente ao longo da vida. Os enchimentos têm vida mais curta e são determinados e adaptados pelos usuários. Segundo os autores corre-se o risco, neste caso, de que a tecnologia torne-se um fim e não um meio para se alcançar a flexibilidade.

De acordo com Brandão (2011), vários autores defendem a importância da flexibilidade, tanto na ocupação inicial dos espaços (flexibilidade inicial), como ao longo de sua utilização (flexibilidade contínua, funcional ou permanente). O autor destaca duas estratégias de projeto defendidas por Palermo et al. (2007 apud BRANDÃO, 2011):

- a flexibilidade de execução, que permite a construção em etapas; e

- a flexibilidade de uso, que facilita a adequação dos espaços às necessidades físicas específicas da família moradora, incluindo eventuais necessidades especiais, com garantia da acessibilidade espacial a pessoas com diferentes níveis de restrição.

Ornstein, Bruna e Romero (1995 apud MARROQUIM; BARBIRATO, 2007) relatam que pesquisas feitas nos anos 70 mostraram que quanto maior a capacidade do edifício em aceitar improvisações de seus usuários, maior será a satisfação dos usuários. Em decorrência destas preferências, ressaltam a relevância da flexibilidade nos arranjos espaciais dos projetos arquitetônicos.

Trabalhos realizados por Brandão (2002 apud MARROQUIM; BARBIRATO, 2007) constataram também que o próprio fato de os ocupantes de uma edificação estarem cientes de que existem possibilidades de fácil modificação ou adaptação, especialmente de layout, tem um efeito positivo sobre a satisfação dos mesmos. 
A importância de promover diversidade e flexibilidade tem sido enfatizada no Brasil em vários estudos recentes realizados sobre o mercado da construção civil brasileira, comenta Brandão (2011). Apesar disso, o autor afirma que os empreendimentos habitacionais, sejam de promoção pública ou privada, são oferecidos, quase sempre, com plantas recorrentes por anos e anos e mesmo em habitações de pequena área, o que se observa são plantas com excessiva compartimentação e tripartição de setores.

\subsection{Assistência técnica para melhoria habitacional}

Outra proposta para minimizar os impactos negativos das modificações realizadas pelos usuários é a disponibilização de assistência técnica para auxiliar a execução dessas alterações. A proposta consiste na disponibilização de assistência técnica de profissionais habilitados para apoio especializado aos moradores que desejam fazer modificações em suas casas. Neste sistema, um engenheiro, arquiteto ou técnico acompanha a obra e orienta os moradores e a mão de obra, de forma individualizada, a modificar e ampliar as moradias, realizando projetos e fornecendo listas de materiais e orçamentos.

No Brasil, algumas experiências com assistência técnica já foram desenvolvidas em diferentes pontos do país, de caráter público ou social, destinadas tanto a moradores de conjuntos habitacionais quanto a moradores de outros tipos de assentamentos, como favelas reurbanizadas e de "bairros pobres". Embora muitos esforços já tenham sido empregados nesse sentido, a viabilização deste serviço no Brasil ainda não foi obtida de forma satisfatória, ou seja, com resultados que sejam possíveis de multiplicação em larga escala (SILVESTRE; CARDOSO, 2012a).

No intuito de viabilizar a assistência técnica pública para habitação, algumas medidas já foram tomadas por parte do poder público. Em 2001, o Estatuto das Cidades - Lei $n^{\circ} 10.257$ de julho de 2001 contemplou pela primeira vez a assistência técnica para habitações construídas em regime de mutirão (BRASIL, 2001). O Plano de Habitação do Governo Federal, o PLANHAB, prevê, para a população de baixa renda, o fornecimento de lotes, cesta de materiais e assistência técnica para a construção, mas não especifica como isso vai acontecer.

O mais novo e específico instrumento nesse sentido, no entanto, é a Lei Federal $n^{\circ} 11.888$ - Lei de Assistência Técnica (BRASIL, 2008), que garante às 
famílias com renda de até 3 salários mínimos assistência técnica gratuita para legalização, construção, reformas e ampliações nas residências. Entretanto, muitas dúvidas ainda cercam a sua implantação, pois as prefeituras, que seriam as responsáveis pela operação de assistência técnica, ainda não encontraram uma forma viável de colocar a lei em prática.

O fato é que cada vez mais a assistência técnica tem se mostrado importante e há grandes esforços para que ela seja implantada em âmbito nacional.

Palhares (2001), ao relatar a experiência do conjunto habitacional Lagoa, declara que a participação dos técnicos nos programas de assistência pode ser muito eficiente na conscientização dos moradores sobre problemas diversos. Com relação às modificações, ele relata certa resistência inicial dos técnicos à sua realização, pois eles defendiam a manutenção do estilo e dos materiais originais das casas. O autor rebate esse posicionamento afirmando que "edificação com o estilo e materiais originais preservados, porém, em más condições de conservação, e sem alternativas de manutenção, não confere nenhuma qualidade aos espaços da habitação".

Para Palhares (2001), todos os agentes do processo devem ter clareza das consequências das modificações antes de aprová-las ou reprová-las. Os números apurados na pesquisa apresentada pelo autor revelaram que as modificações resolveram muitos problemas, melhorando a qualidade dos espaços e, por extensão, a qualidade de vida dos moradores. 


\section{METODOLOGIA DA PESQUISA}

Esta pesquisa foi dividida em três fases distintas: a revisão da bibliografia existente, a realização dos três estudos de caso e a compilação dos dados e análise dos resultados. Estas fases são detalhadas nos itens a seguir.

\subsection{Revisão Bibliográfica}

A primeira fase de desenvolvimento desta pesquisa foi a realização de uma revisão da bibliografia sobre assuntos relacionados à habitação popular, conjuntos habitacionais, avaliação pós-ocupação e sistemas construtivos. Para tanto, foram levantados e analisados os principais autores e obras acerca dos temas, buscandose consultar diferentes linhas de pensamento, analisando teorias e propostas tradicionais e inovadoras, de modo a confrontar as opiniões divergentes.

Outra atividade importante desta etapa foi a busca por experiências de avaliação pós-ocupação já realizadas, com maior foco naquelas que abordaram os sistemas construtivos e o estudo das modificações realizadas pelos moradores nas unidades habitacionais.

\subsection{Estudos de Caso}

\subsubsection{Definição da região e empreendimentos estudados}

Para o cumprimento dos objetivos estabelecidos, foram realizados estudos de caso em empreendimentos considerados interessantes e relevantes para a elaboração desta pesquisa por utilizarem processos construtivos diferenciados.

Para a escolha dos empreendimentos estudados, foram definidos os seguintes pré-requisitos:

- obra pública de HIS;

- empreendimento horizontal com unidades unifamiliares térreas (isoladas ou geminadas); 
- unidades habitacionais entregues há, no mínimo, 1 ano, tempo considerado razoável para uma avaliação mais criteriosa por parte dos usuários e para a realização de modificações nessas unidades;

- empreendimentos que utilizam processos construtivos racionalizados e/ ou industrializados a base de cimento e que foram acompanhados, de alguma forma, pela Associação Brasileira de Cimento Portland (ABCP) durante a fase de execução;

- apresentam maiores facilidades de acesso aos agentes da política pública e, especialmente, aos moradores.

Outro importante fator considerado na escolha dos empreendimentos foi a localização, uma vez que ela influi em muitos aspectos a serem estudados, tais como: clima, relevo, situação econômica das famílias e do município, aspectos culturais etc.

Por essa razão, buscou-se identificar empreendimentos de uma mesma região, aumentando as chances de se ter condições climáticas e socioculturais semelhantes ou aproximadas, o que tem grande influência e relevância para a realização de comparações entre os casos.

Dessa forma, após a análise de alguns empreendimentos e regiões, optou-se pela realização de três estudos de caso em empreendimentos da Companhia de Desenvolvimento Habitacional e Urbano do Estado de São Paulo (CDHU) em três cidades distintas na região do Vale do Paraíba, conforme descrição a seguir:

1. Conjunto Habitacional São Luiz do Paraitinga "C" - sistema construtivo RBS de concreto PVC.

2. Conjunto Habitacional Cunha "B" - sistema construtivo de paredes de concreto celular moldadas in loco.

3. Conjunto Habitacional Lagoinha "A" - sistema construtivo de alvenaria estrutural com blocos de concreto.

A escolha desta região para realização dos estudos de caso foi fundamentada na facilidade de acesso da autora à região e dos laços de relacionamento já existentes com agentes locais da política pública e entidades da região.

Entende-se, também, que a proximidade entre as três cidades e o fato de pertencerem à mesma região confere maior homogeneidade entre as populações 
pesquisadas, o que reverte em informações mais interessantes para a realização desta pesquisa.

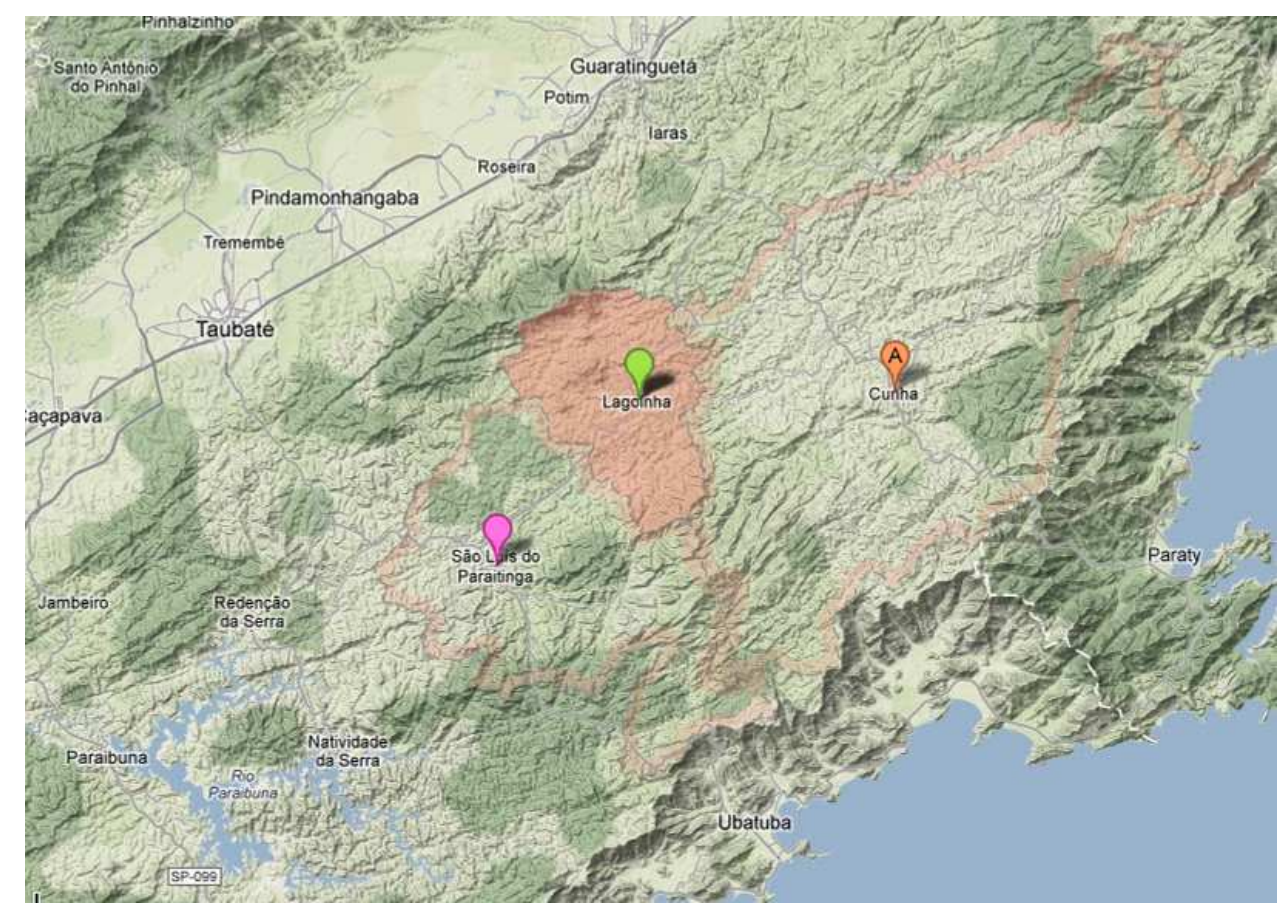

Figura 2 - Mapa de localização das cidades escolhidas

Fonte: Google Maps.

A fim de permitir uma maior compreensão sobre as cidades visitadas, 0 ANEXO I apresenta um quadro resumo com o perfil de cada um dos três municípios em comparação com a totalidade do Estado de São Paulo.

\subsubsection{Preparação e Realização da Pesquisa de Campo}

A realização desses estudos de caso tem como finalidade o cumprimento dos objetivos secundários desta pesquisa, conforme mencionados no capítulo 1, e, para sua realização, foram realizadas avaliações pós-ocupação nas unidades habitacionais com foco em avaliações funcionais e dos sistemas construtivos, utilizando alguns dos métodos e técnicas de avaliação pós-ocupação descritos no item 3.4.

Para a avaliação dos sistemas construtivos, foi adotada a abordagem dos dez órgãos básicos da edificação apresentada por Roméro e Ornstein (2003). A avaliação funcional será realizada através e uma avaliação de uso (AU) executada a partir de diversos instrumentos de APO. 
Anteriormente à realização da pesquisa em campo, foi necessária a realização de uma vasta pesquisa de documentos e projetos relativos aos empreendimentos de forma que estes pudessem contribuir para a sua caracterização e mesmo para a aplicação dos métodos e técnicas selecionados.

Como foram realizados 3 estudos de caso simultâneos e com uma equipe extremamente reduzida, foi necessária a utilização de métodos e técnicas que permitissem uma aplicação rápida e fácil em campo e, também, que permitissem que as informações coletadas fossem facilmente consultadas e analisadas posteriormente. Assim, para a realização dessas avaliações, foram utilizados os seguintes instrumentos de APO, já descritos no item 3.4:

- aplicação de entrevistas não estruturadas com profissionais da CDHU e demais entidades e empresas participantes do projeto e execução dos empreendimentos;

- aplicação de entrevistas estruturadas com usuários dos imóveis;

- aplicação da técnica de Walkthrough;

- realização de registros de imagem (fotos e croquis) e vídeo.

Anteriormente à aplicação desses instrumentos, foi necessário o desenvolvimento de fichas e formulários padronizados, focando a obtenção dos dados através de uma linguagem simples e de fácil assimilação pelos entrevistados.

Também foi elaborado um roteiro técnico para que as avaliações seguissem um mesmo padrão de coleta e armazenamento de informações para todas as unidades e empreendimentos pesquisados, evitando distorções nos resultados comparativos.

As entrevistas com profissionais não tinham um roteiro estruturado, entretanto, procurou-se, com elas, obter as informações necessárias para completar - Formulário de Caracterização do Empreendimento, preenchendo-se um documento destes para cada um dos empreendimentos visitados. Esse formulário está apresentado no Apêndice $B$.

Já as ferramentas de entrevistas com moradores e aplicação da técnica de Walkthrough foram testadas através da realização de um pré-teste para avaliar a sua eficácia e capacidade de fornecer as informações desejadas. Essa etapa foi realizada no empreendimento São Luiz do Paraitinga "C" e, na ocasião, participaram 
dois pesquisadores, a autora e uma auxiliar, sendo visitadas três casas, o que foi suficiente para se observar algumas falhas neste material preliminar.

A primeira versão do formulário foi elaborada em 12 páginas e, de modo geral, o pré-teste mostrou que estava muito extensa e cansativa para os moradores, que no final já deixavam de responder com tanta atenção e preocupação com o detalhamento e veracidade das informações prestadas. Também foi observado que algumas questões referentes à caracterização das famílias, sobretudo aquelas relacionadas à renda e bens de consumo, não eram bem recebidas pelos moradores, o que causava certa rejeição em prestar outras informações mais relevantes para os resultados da pesquisa.

Assim, esse formulário foi revisto e algumas questões foram eliminadas ou condensadas para possibilitar maior facilidade na aplicação e menor rejeição por parte dos moradores. A versão final do formulário de visita às moradias conta com 7 páginas, sendo as partes I a IV destinadas à entrevista com os moradores e as partes $\mathrm{V}$ e VI destinadas à aplicação da técnica de Walkthrough, com informações coletadas pelos técnicos. Esta versão final está apresentada no Apêndice $\mathrm{C}$.

Após a realização do pré-teste e elaboração da versão final do formulário, foram programadas as visitas aos empreendimentos, sempre realizadas pela autora e uma acompanhante para auxiliar na coleta das informações.

Para a definição da amostra necessária em cada um dos empreendimentos, o universo de casas foi considerado homogêneo, uma vez que se destina a uma população bem específica.

A escolha das casas visitadas não atendeu a nenhum método estatístico, sendo selecionadas aquelas casas em que havia moradores dispostos a responder a pesquisa no momento da visita. Procurou-se, no entanto, obter-se uma amostra mínima de $25 \%$ das unidades habitacionais em cada conjunto habitacional. Buscouse, também, obter uma variação quanto à posição das casas em relação ao Sol, ao seu posicionamento na rua e no empreendimento e à realização de modificações externas aparentes.

\subsection{Análise e Considerações}

Uma vez coletadas as informações, estas foram compiladas através de planilhas e gráficos, de forma que fosse possível obter dados estatísticos 
relacionados a cada um dos empreendimentos e com relação ao total do universo pesquisado. A partir da compilação das informações foi possível realizar uma análise crítica sobre os resultados obtidos.

Os capítulos 6, 7 e 8, a seguir, apresentam o detalhamento e os resultados dos estudos de caso realizados nos conjuntos habitacionais São Luiz do Paraitinga "C", Cunha "B" e Lagoinha "A", respectivamente.

O capítulo 9 faz uma discussão global dos resultados. 


\section{O CASO DE SÃO LUIZ DO PARAITINGA}

Para realização do primeiro estudo de caso, optou-se pelo Conjunto Habitacional São Luiz do Paraitinga "C", que já havia sido alvo de estudos da autora durante a realização do trabalho final da disciplina PCC 5017 - Processo de Projeto na Construção Civil, cursada durante o mestrado. $O$ empreendimento em questão apresenta características muito marcantes que influenciaram na sua escolha, como o cenário em que foi realizado e o sistema construtivo utilizado. Essas características serão detalhadas a seguir.

\subsection{O Empreendimento}

\subsubsection{Cenário}

O município de São Luiz do Paraitinga está localizado no Vale do Paraíba, no Estado de São Paulo, a cerca de 200 quilômetros da cidade de São Paulo, e faz divisa com os municípios de Ubatuba, Taubaté, Lagoinha, Cunha, Natividade da Serra e Redenção da Serra. Apresenta uma área de $617,15 \mathrm{~km}^{2}$ e uma população de 10.427 habitantes em 2010 (FUNDAÇÃO SEADE, 2012).

Seu clima, assim como o clima dos demais municípios da região, é temperado com inverno seco e sua topografia é acidentada, com relevo montanhoso. É banhado pelos rios Paraibuna, Paraíba e Paraitinga, sendo que o nome deste último, que vem da palavra indígena parahytinga (águas claras), dá nome à cidade (EMPLASA GEO, 2012).

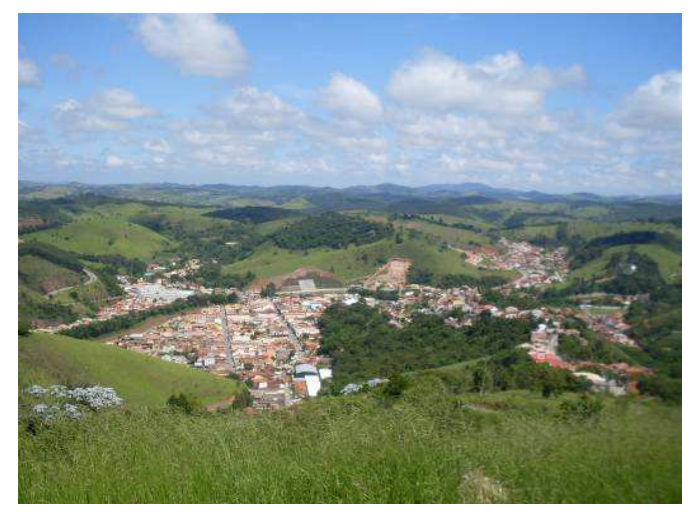

Figura 3 - Vista da cidade de São Luiz do Paraitinga Fonte: a autora. 
As primeiras sesmarias nos sertões do Rio Paraitinga foram concedidas em 1688, mas somente em 2 de maio de 1769 ocorreu a fundação do povoado de São Luiz e Santo Antônio do Paraitinga, que deu origem ao município de São Luís do Paraitinga. A capela existente, construída em louvor a Nossa Senhora dos Prazeres, mudou depois para São Luís de Tolosa. Em 1773, São Luiz recebeu o status de vila e em 1857 uma lei provincial elevou-a à categoria de cidade. Bem mais tarde, em 2002, a cidade transformou-se em Estância Turística (EMPLASA GEO, 2012).

Durante um longo período, a economia do município permaneceu restrita à cultura de cereais, até que se iniciaram as plantações de café e algodão. A partir da década de 30 , a pecuária leiteira começou a se sobressair, tornando-se a principal atividade econômica, ao lado da agricultura de subsistência, que voltou a ganhar importância com a queda da produção cafeeira. Hoje a cidade conta com um Produto Interno Bruto (PIB) de $\mathrm{R} \$ 89,49$ milhões (2010), sendo que mais de $70 \%$ desse valor vem da prestação de serviços. (EMPLASA GEO, 2012; FUNDAÇÃO SEADE, 2012).

A cidade de São Luiz do Paraitinga, berço do sanitarista Oswaldo Cruz (18721917), também chama a atenção pelo casario de 437 imóveis dos séculos XVIII e XIX tombados pelo Conselho de Defesa do Patrimônio Histórico, Arqueológico, Artístico e Turístico (CONDEPHAAT), por ter um dos carnavais de rua mais concorridos do estado e pela tradicional Festa do Divino (BERGAMO, 2010).

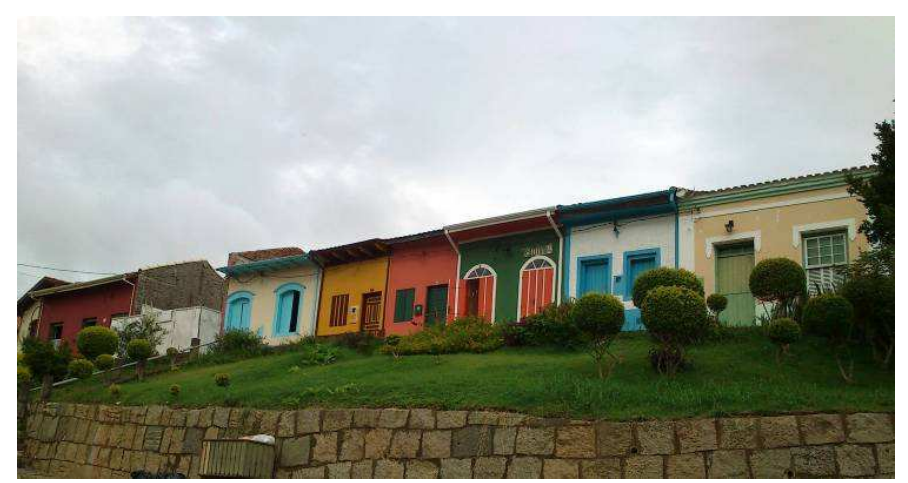

Figura 4 - Imóveis tombados pelo patrimônio histórico Fonte: a autora.

Na virada de 2009 para 2010 a cidade foi destruída pela maior enchente já registrada ali. O nível do Rio Paraitinga, que atravessa a cidade, subiu de 10 a 15 metros acima do normal e a água atingiu mais da metade dos imóveis, cobrindo os 
telhados e danificando a estrutura de muitos deles, a maioria construída com taipa de pilão e pau a pique. Estima-se que cerca de 300 edificações tenham sido total ou parcialmente danificadas, entre elas edificações históricas, como a Igreja Matriz São Luiz de Tolosa, de mais de 200 anos (BERGAMO, 2010; MARRA, 2010).

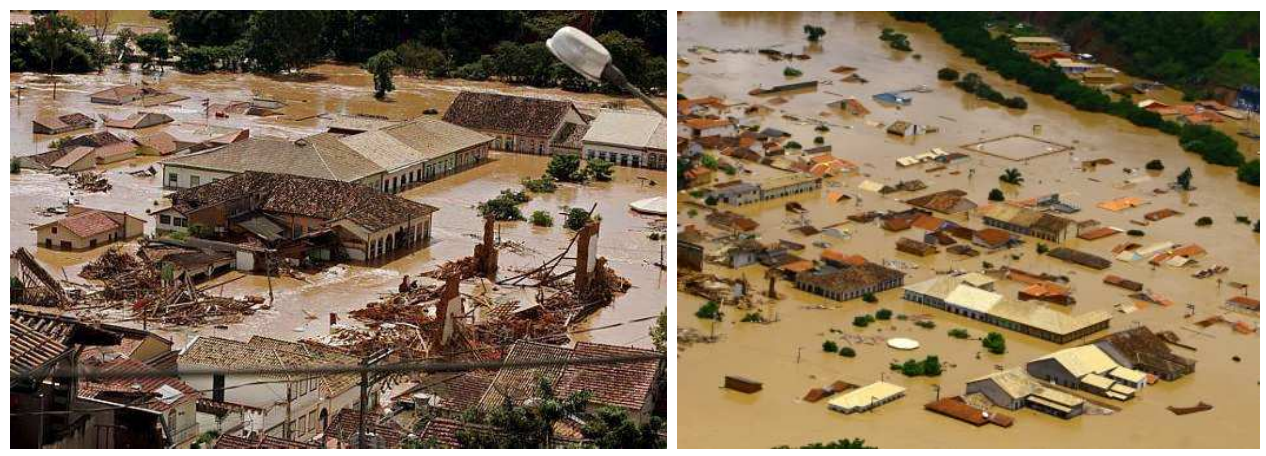

Figura 5 - Enchente atinge São Luiz do Paraitinga

Fontes: Sergio Neves/ Agência Estado; Rogério Marques/ Agência Estado/ Portal R7.com.

Tendo em vista o cenário desolador de toda a região, o Governo do Estado anunciou um investimento de 10 milhões de reais em ações emergenciais para todo - Vale do Paraíba, além da reconstrução e reforma de unidades de saúde e liberação de crédito para a população (BERGAMO, 2010). Em poucos dias, os trabalhos de reconstrução foram iniciados e, pouco a pouco, as ruas foram desobstruídas, o entulho foi recolhido e o comércio reabriu suas portas, mas, ainda assim, restavam muitas famílias vivendo em áreas de risco e muitos desabrigados, todos necessitando com urgência de uma nova moradia.

Um plano emergencial foi montado para a construção de habitações de interesse social, visando à rapidez de construção e à qualidade dessas edificações. As primeiras moradias foram realizadas por ação da Companhia de Desenvolvimento Habitacional e Urbano do Estado de São Paulo (CDHU). A infraestrutura urbana, a pavimentação, a implantação urbana e as fundações das edificações foram realizadas pela empresa Terracom e as casas foram erguidas pela empresa Royal do Brasil Technologies com o sistema de paredes de concreto com fôrmas fixas de PVC, com acompanhamento técnico da Associação Brasileira de Cimento Portland (ABCP) e da Braskem durante a construção.

Após três anos da ocorrência da catástrofe, muitas obras já foram realizadas e a vida da maioria dos moradores já voltou ao normal, entretanto, a cidade ainda luta para minimizar os efeitos de novos desastres e finalizar a reconstrução de seu 
patrimônio histórico. Obras de contenção de encostas ainda podem ser vistas em alguns pontos da cidade e a Igreja do Rosário, a Igreja Matriz e alguns dos casarões do centro histórico ainda estão em obras de reconstrução e restauração.
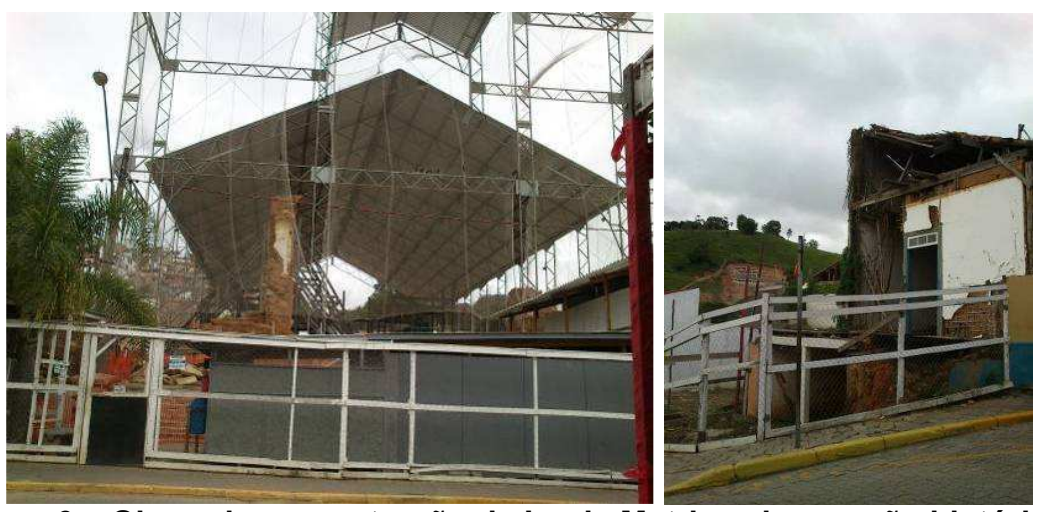

Figura 6 - Obras de reconstrução da Igreja Matriz e de casarão histórico Fonte: A autora.

\subsubsection{Descrição e histórico}

O empreendimento São Luiz do Paraitinga "C", nomeado como Conjunto Habitacional Monsenhor Tarcísio de Castro Moura, ocupa uma área de 130.943,98 $\mathrm{m}^{2}$ e é acessado exclusivamente pela Av. Celestino Campos Coelho, $\mathrm{s} / \mathrm{n}^{\circ}$, a apenas $700 \mathrm{~m}$ do centro da cidade de São Luiz do Paraitinga.

A gleba apresenta declividade acentuada, com trechos superiores a $30 \%$, mas não há terrenos alagadiços e sujeitos a inundação. $O$ terreno conta, também, com uma extensa área verde, dividida em quatro partes, sendo que a maior delas fica na região mais alta da gleba. Há, ainda, três áreas destinadas a equipamentos de lazer e duas áreas institucionais.

A figura 8 a seguir apresenta a implantação do conjunto habitacional: 


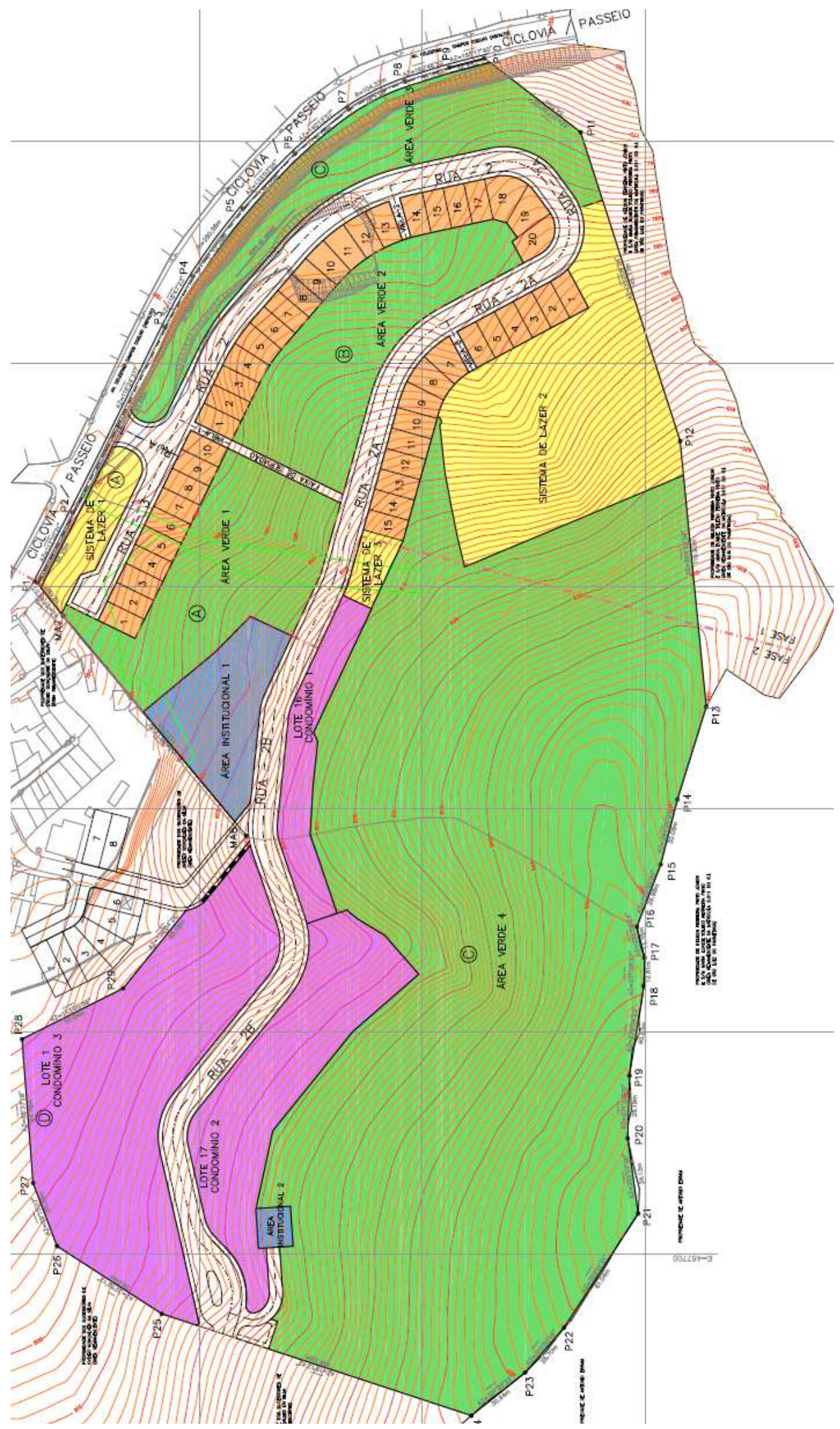

Figura 7 - Implantação do Conjunto Habitacional São Luiz do Paraitinga "C" Fonte: CDHU, 2010. 
As ruas apresentam pavimento intertravado de concreto e as calçadas têm a faixa livre, ou passeio, em concreto e vegetação nas faixas de serviço e de acesso.

O conjunto habitacional conta, ainda, com iluminação das vias púbicas através de postes com fiação aérea, rede de abastecimento de água, rede de coleta de esgotos, rede de captação de águas pluviais e serviço de coleta de lixo.

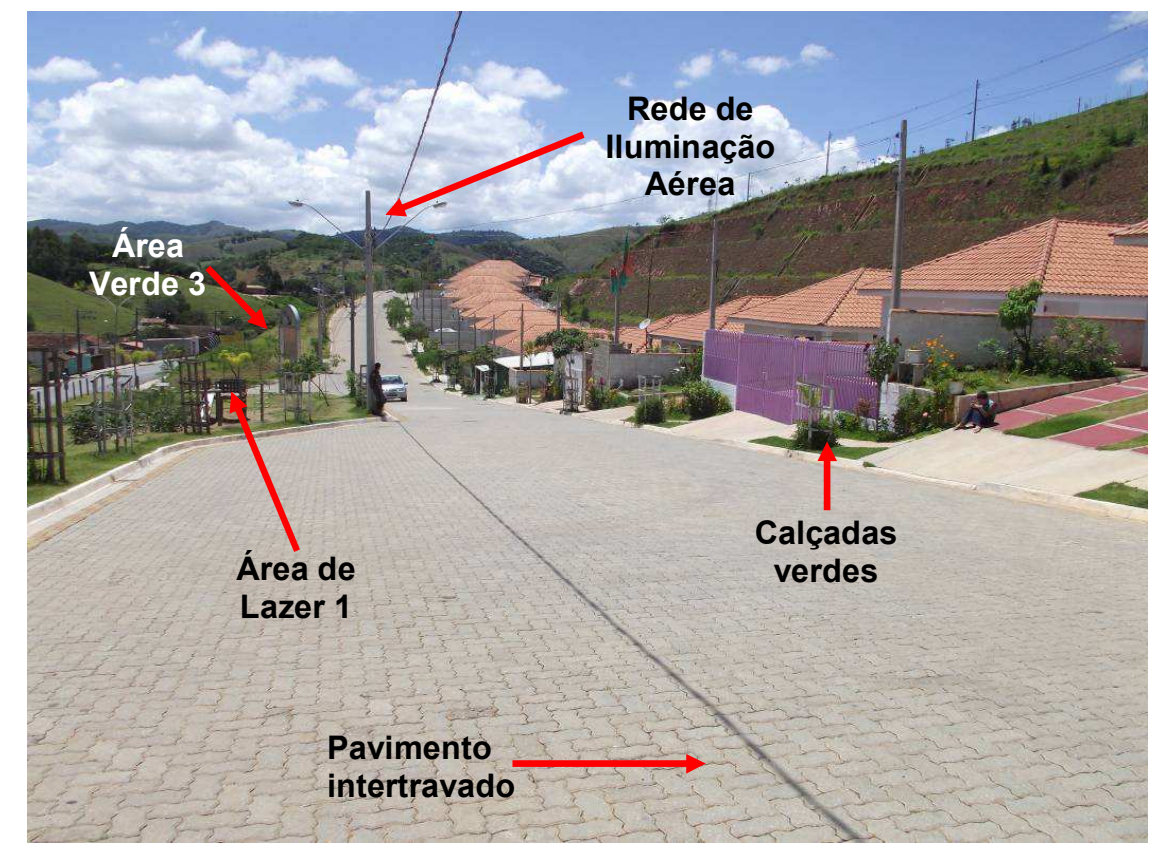

Figura 8 - Vista geral do Conjunto Habitacional São Luiz do Paraitinga "C" Fonte: Acervo ABCP.

Dada a urgência de início das obras, optou-se pela utilização de projetospadrão da CDHU, que possui uma série de modelos de unidades habitacionais já com custo e detalhamento bem definidos.

Foram escolhidas, para o empreendimento em questão, duas tipologias distintas, sendo 106 sobrados de $54,36 \mathrm{~m}^{2}$, seguindo a tipologia SR23A, e 45 casas térreas de $65,90 \mathrm{~m}^{2}$ de área construída, de acordo com a tipologia TG33A. No total, foram executadas 151 unidades habitacionais, totalizando $8.727,66 \mathrm{~m}^{2}$ de área construída.

A escolha das tipologias utilizadas se deu em virtude das características de implantação, considerando as dimensões dos lotes e as necessidades das famílias atendidas.

Para execução das casas e sobrados, entretanto, esses projetos tiveram que ser adaptados ao sistema construtivo. Segundo Ferrari (2011), uma vez definidas as 
tipologias das casas, toda a fase de adaptação e compatibilização do projeto foi realizada pela empresa detentora da tecnologia construtiva, a Royal do Brasil Technologies, e submetida à aprovação da CDHU.

Essa adaptação compreendeu, principalmente, a adequação da modulação do projeto-padrão à modulação do sistema construtivo, o que acabou por requerer a realização de alguns outros ajustes, como a realocação de instalações e esquadrias.

Como estratégia para a modulação do projeto, optou-se por utilizar os perfis de PVC com $100 \mathrm{~mm}$ de espessura. Assim, foi possível manter a área útil projetada, reduzindo a área construída em função da diferença de espessura existente entre os painéis de PVC e a parede do projeto original. A diferença de área construída foi de $1,52 \mathrm{~m}^{2}$ a menos, com um ganho de área útil de quase $3 \mathrm{~m}^{2}$.

Segundo Ferrari (2011), também foram realizadas alterações na cobertura, que inicialmente teria duas águas. Segundo o autor, durante a etapa de adequação do projeto foi proposta uma cobertura de quatro águas, por motivos estéticos, tomando como referência as coberturas encontradas na região (informação verbal) ${ }^{1}$.

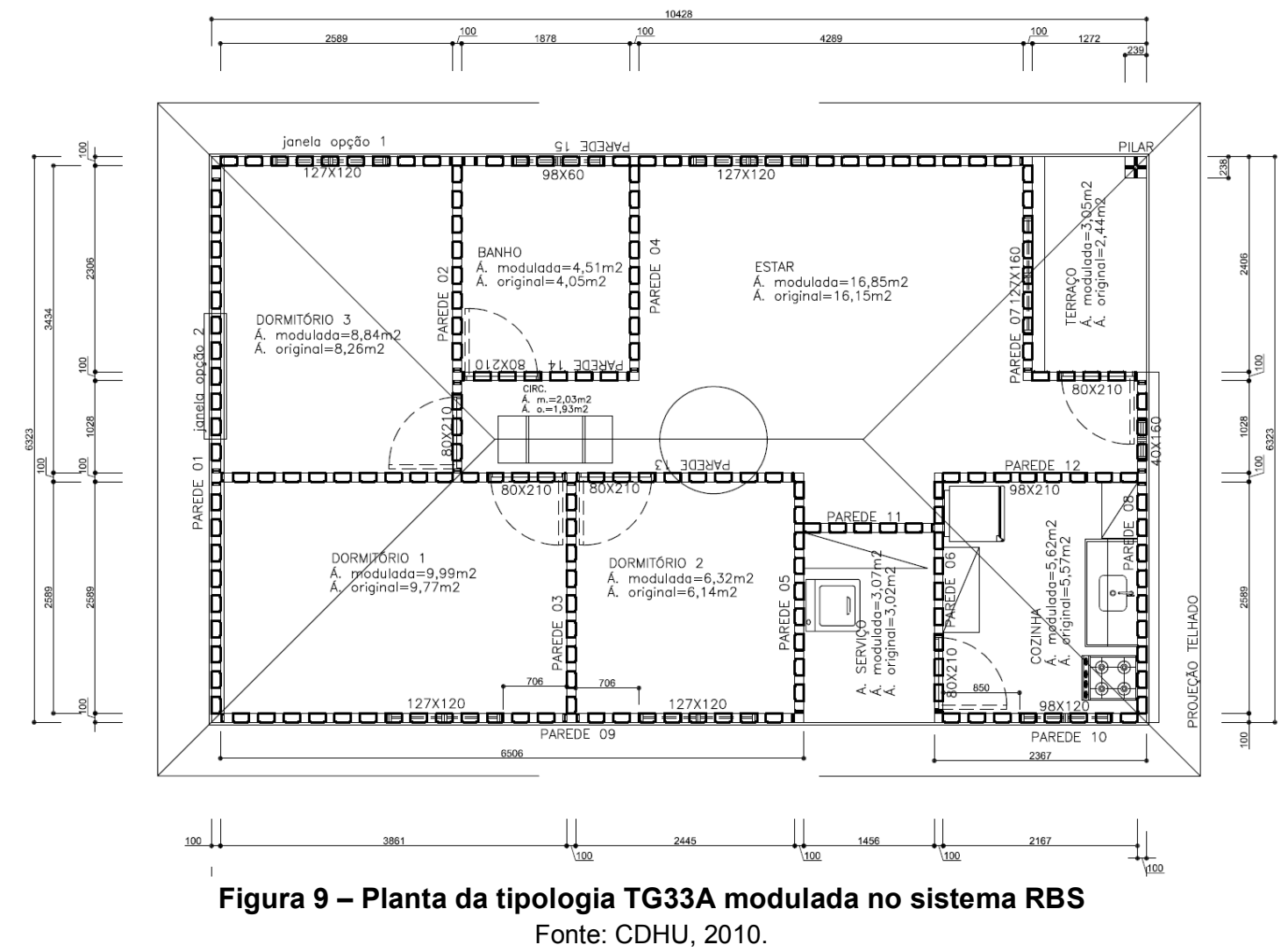

\footnotetext{
${ }^{1}$ Informação fornecida pelo $\mathrm{Arq}^{\circ}$ Tiago Ferrari em entrevista por telefone em 07/11/2011.
} 


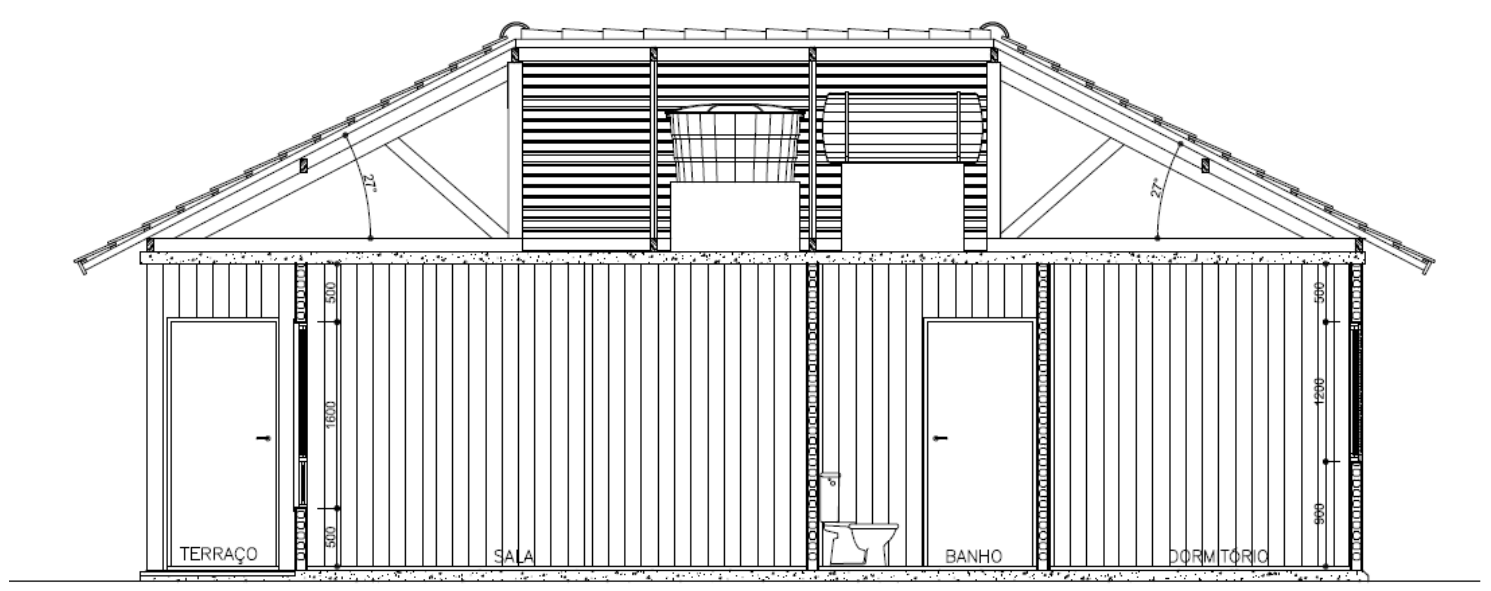

Figura 10 - Corte longitudinal da tipologia TG33A modulada no sistema RBS Fonte: CDHU, 2010.

Não foi necessário o revestimento de nenhuma parede, pois os painéis já possuem acabamento adequado para utilização sem revestimentos adicionais.

Foi realizado, ainda, um estudo de cores com referência na tipologia de fachada das casas da região. Dessa forma, foi elaborada uma proposta de aplicação de pintura ou textura remetendo aos detalhes típicos da região, sendo que as casas foram entregues com as fachadas predominantemente brancas, com alguns detalhes em cor (FERRARI, 2011).

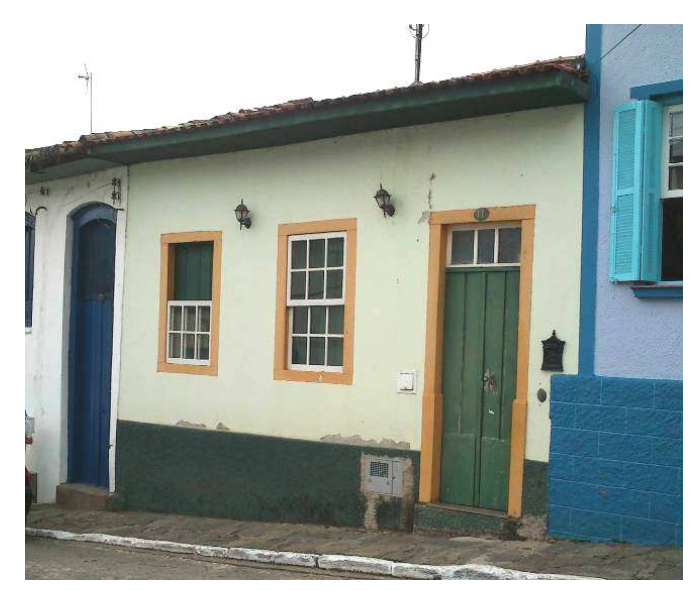

Figura 11 - Tipologia de fachada das casas em São Luiz do Paraitinga Fonte: A autora. 

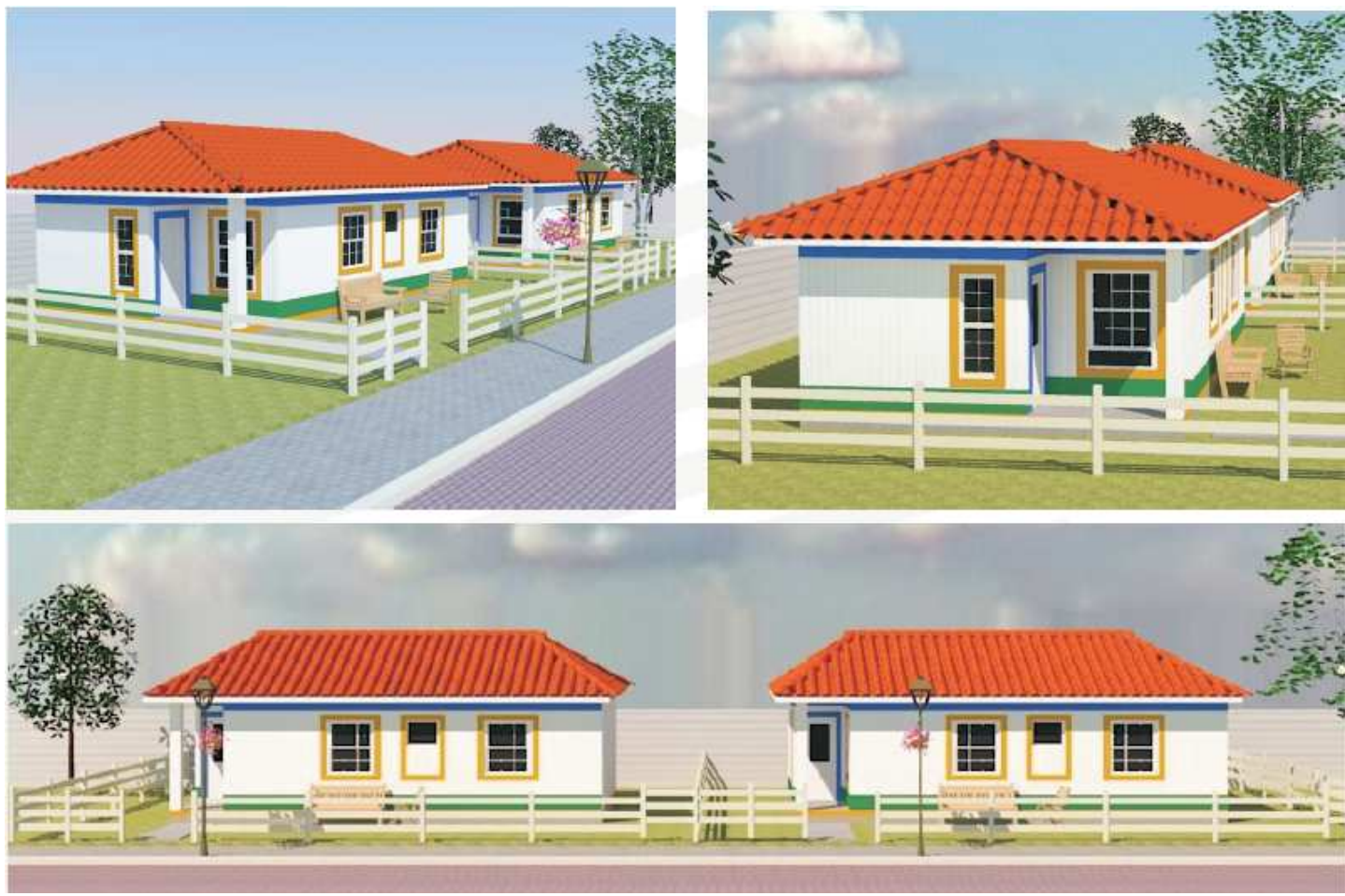

Figura 12 - Estudo de cores para fachadas das unidades Fonte: Royal Technologies do Brasil.

As reuniões das equipes de projeto e execução foram constantes desde o início do contato até a entrega definitiva das casas, período que durou 6 meses.

Segundo Ferrari (2011), as primeiras reuniões foram mais focadas no projeto em si e, conforme a obra começou a ser executada, passou a ser avaliada a sua evolução. Como o empreendimento foi realizado em caráter emergencial, as reuniões eram realizadas quinzenalmente nos quatro primeiros meses e nos dois últimos meses essas reuniões passaram a ser semanais (informação verbal) ${ }^{2}$.

Em geral, participavam dessas reuniões o diretor executivo da CDHU e profissionais do departamento de projetos da CDHU, da empresa gerenciadora do contrato, da empresa fiscalizadora do contrato, representantes da prefeitura e técnicos das duas empresas responsáveis pela execução.

No caso da execução das unidades habitacionais, a mesma empresa fez a adequação e compatibilização dos projetos e a execução da obra, o que contribuiu muito para a redução de imprevistos e problemas na etapa de execução.

\footnotetext{
${ }^{2}$ Informação fornecida pelo $\mathrm{Arq}^{\circ}$ Tiago Ferrari em entrevista por telefone em 07/11/2011.
} 
Logo no início dos serviços, foi realizada uma alteração no projeto de implantação, o que impactou no projeto das edificações. Com essa mudança, as unidades assobradadas, que antes eram geminadas apenas em grupos de seis unidades, passaram a ser agrupadas em grupos de quatro e seis unidades.

Segundo o arquiteto Tiago Ferrari, da empresa Royal do Brasil Technologies, a principal dificuldade encontrada na etapa de execução do empreendimento foi o ajuste do ritmo de execução das duas empresas que trabalhavam no canteiro, pois o ritmo de execução das obras de infraestrutura e arruamentos era menor do que o ritmo de construção das casas, o que exigiu um remanejamento das equipes de trabalho das duas empresas (informação verbal) ${ }^{3}$.

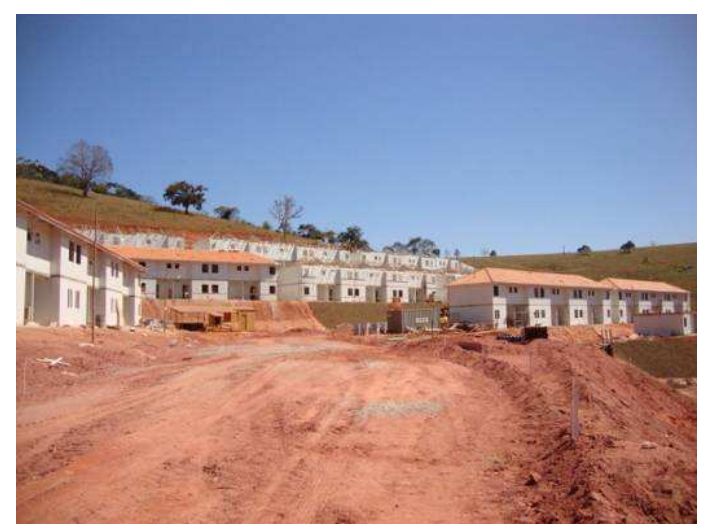

Figura 13 - Fotos da execução das obras em São Luiz do Paraitinga Fonte: acervo ABCP.

Em parte, esse descompasso entre as equipes se deve às dificuldades encontradas com o terreno, que é extremamente acidentado, e à falta de estrutura da cidade naquele momento em que ainda estava se recuperando da tragédia causada pelas enchentes. Essas dificuldades acabaram atrasando a equipe de infraestrutura, que ficou defasada em relação à equipe de execução das edificações.

Outra característica muito particular desse empreendimento é que a equipe que realizou a adaptação e compatibilização do projeto ficou residente em obra durante toda a fase de execução, ajudando no controle da obra e resolvendo eventuais divergências no momento em que elas aconteciam (FERRARI, 2011; informação verbal) ${ }^{4}$.

\footnotetext{
${ }^{3}$ Informação fornecida pelo $\operatorname{Arq}^{\circ}$ Tiago Ferrari em entrevista por telefone em 07/11/2011.

${ }^{4}$ Informação fornecida pelo $\mathrm{Arq}^{\circ}$ Tiago Ferrari em entrevista por telefone em 07/11/2011.
} 
As 151 casas foram entregues em setembro de 2010 e todos os moradores receberam um manual do usuário com as instruções sobre a utilização das casas. Esse manual foi elaborado pela empresa que elaborou o projeto e executou a obra, sob orientação dos técnicos da CDHU, e traz informações sobre limpeza, manutenção e ampliações (FERRARI, 2011).

As unidades habitacionais do Conjunto São Luiz do Paraitinga "C" foram entregues já de acordo com as novas diretrizes da CDHU, incluindo toda a parte de acabamento.

A tabela 1, a seguir, apresenta uma descrição das casas entregues baseada nos 10 órgãos básicos do edifício apresentados por Roméro e Ornstein (2003):

Tabela 1 - Descrição das unidades do Conjunto São Luiz do Paraitinga "C"

\begin{tabular}{|c|c|}
\hline $\begin{array}{l}\text { Órgão do } \\
\text { Edifício }\end{array}$ & Descrição \\
\hline Terrapleno & $\begin{array}{l}\text { Os lotes foram entregues demarcados, com muros laterais e de fundos. } \\
\text { Apenas uma pequena porção do terreno foi cimentado na faixa de acesso } \\
\text { de pedestres ao interior da unidade e nas faixas de acesso e } \\
\text { estacionamento de veículo na frente do lote. O restante do terreno foi } \\
\text { gramado ou coberto por pedrisco. }\end{array}$ \\
\hline Fundação & fundação adotada é do tipo radier, com espessura de $10 \mathrm{~cm}$. \\
\hline Estrutura & $\begin{array}{l}\text { estrutura é composta de perfis de PVC preenchidos com concreto e } \\
\text { é-laje. }\end{array}$ \\
\hline Cobertura & Estrutura de madeira e telhas cerâmicas. \\
\hline Vedações & $\begin{array}{l}\text { A vedação é realizada pela própria estrutura de perfis de PVC } \\
\text { preenchidos com concreto. }\end{array}$ \\
\hline & ortas e janelas de PVC, com persianas retráteis nos dormitórios. \\
\hline Paramentos & O acabamento das paredes é feito pelos próprios perfis de PVC. \\
\hline Pisos & $\begin{array}{l}\text { Todo o interior da casa é revestido por piso cerâmico antiderrapante em } \\
\text { tom de bege. }\end{array}$ \\
\hline Instalações & $\begin{array}{l}\text { Instalação elétrica e hidráulica convencional, com eletrodutos plásticos, } \\
\text { tubulação de PVC e fiação de cobre encapada. }\end{array}$ \\
\hline
\end{tabular}




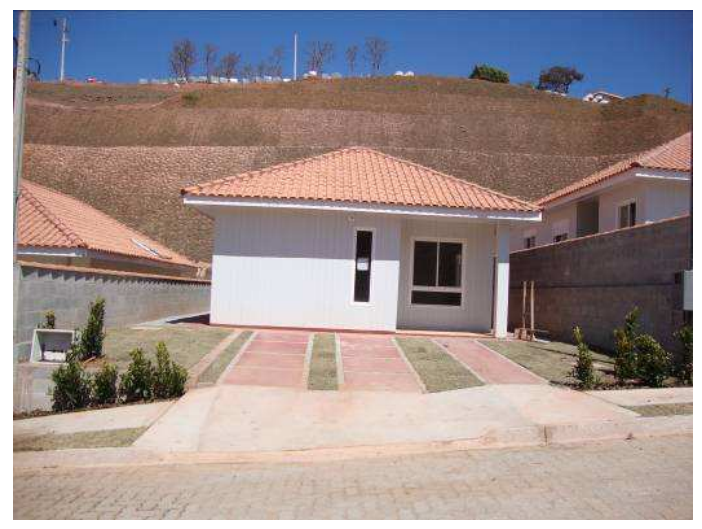

Figura 14 - Casa entregue em São Luiz do Paraitinga Fonte: acervo $A B C P$.
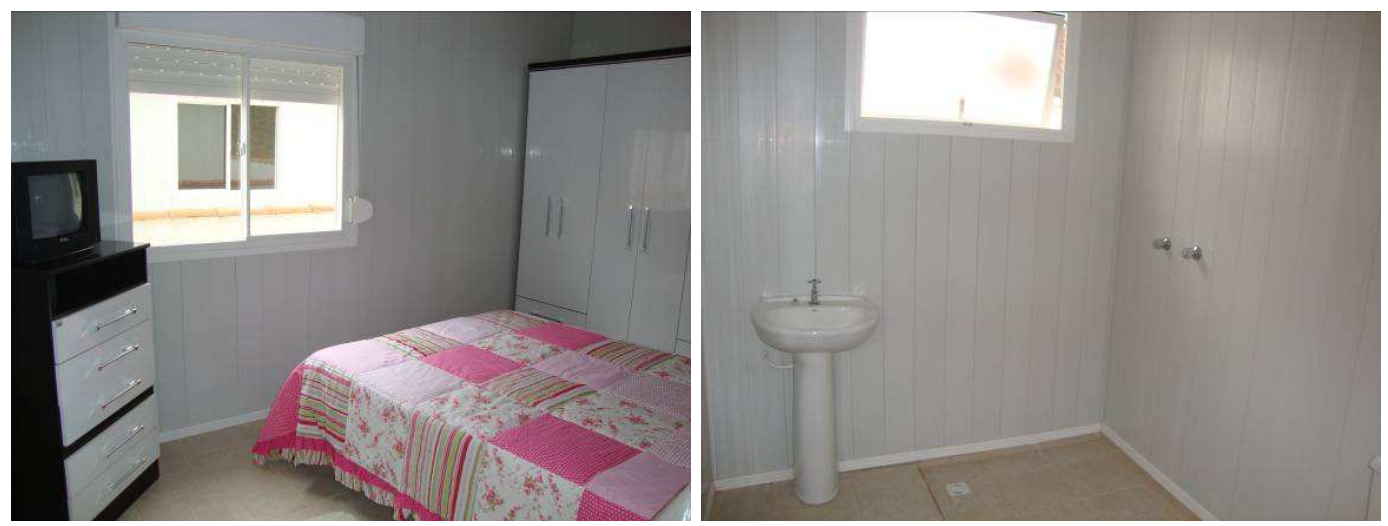

Figura 15 - Interior de uma das casas logo após a entrega Fonte: acervo ABCP.

Os profissionais envolvidos no projeto e na execução visitaram as casas antes e depois da entrega aos moradores e, com a ajuda da ONG InterAção, foi realizada uma avaliação em alguns imóveis, que consistiu em rápidas entrevistas com os moradores para avaliar o seu grau de satisfação com a moradia (FERRARI, 2011).

Durante as entrevistas, era solicitado aos moradores que classificassem em ÓTIMO, BOM, REGULAR, RUIM ou PÉSSIMO alguns itens pré-determinados referentes à qualidade da casa e ao seu conforto ambiental. A síntese dessa avaliação foi apresentada por Ferrari (2011) e pode ser observada na tabela a seguir: 
Tabela 2 - Síntese da avaliação de satisfação realizada pela ONG InterAção

\begin{tabular}{|l|c|c|c|c|c|}
\hline \multicolumn{1}{|c|}{ Qualidade } & Ótimo & Bom & Regular & Ruim & Péssimo \\
\hline Estrutura & $48 \%$ & $48 \%$ & & & $4 \%$ \\
\hline Materiais & $45 \%$ & $41 \%$ & $10 \%$ & $4 \%$ & \\
\hline Construção & $38 \%$ & $52 \%$ & $10 \%$ & $3 \%$ & \\
\hline Acabamento & $34 \%$ & $45 \%$ & $21 \%$ & & \\
\hline Parte elétrica & $45 \%$ & $52 \%$ & $3 \%$ & & \\
\hline Parte hidráulica & $45 \%$ & $55 \%$ & & & \\
\hline
\end{tabular}

\begin{tabular}{|l|c|c|c|c|c|}
\hline \multicolumn{1}{|c|}{ Conforto } & Ótimo & Bom & Regular & Ruim & Péssimo \\
\hline Temperatura & $45 \%$ & $45 \%$ & $10 \%$ & & \\
\hline Ruído, barulho & $41 \%$ & $53 \%$ & & $3 \%$ & $3 \%$ \\
\hline lluminação & $47 \%$ & $47 \%$ & $3 \%$ & & $3 \%$ \\
\hline Tamanho & $31 \%$ & $41 \%$ & $21 \%$ & $7 \%$ & \\
\hline Privacidade & $38 \%$ & $48 \%$ & $7 \%$ & $7 \%$ & \\
\hline Limpeza e higiene & $48 \%$ & $48 \%$ & $4 \%$ & & \\
\hline
\end{tabular}

Fonte: FERRARI, 2011.

Durante essas visitas, os técnicos puderam observar outra particularidade desse empreendimento, a heterogeneidade dos moradores, que apresentam uma razoável diferença no nível sociocultural, o que não costuma acontecer em empreendimentos de HIS. Isso se deve ao fato de a execução do empreendimento ter sido motivada pela tragédia que atingiu praticamente toda a cidade, desabrigando pessoas de diferentes níveis socioculturais (FERRARI, 2011).

Alguns meses após a entrega do empreendimento, os técnicos já constatavam a realização de diversas alterações feitas pelos moradores nas casas, seja para aumento da área de moradia ou para ter mais privacidade (FERRARI, 2011; informação verbal) ${ }^{5}$.

\subsubsection{Sistema Construtivo: Concreto PVC - Royal Building Systems (RBS)}

O "Concreto PVC", como ficou popularmente conhecido o processo construtivo de paredes de concreto com fôrmas fixas de PVC, foi escolhido para este empreendimento por proporcionar a rapidez e qualidade necessárias naquele momento, oferecendo uma cadeia de fornecedores pronta a ajudar na construção das casas.

\footnotetext{
${ }^{5}$ Informação fornecida pelo $\mathrm{Arq}^{\circ}$ Tiago Ferrari em entrevista por telefone em 07/11/2011.
} 
No caso de São Luiz do Paraitinga, especificamente, foi utilizado o sistema RBS - Royal Building Systems, um dos sistemas de Concreto PVC existentes no mercado.

\subsubsection{Materiais}

Como o próprio nome já diz, os principais materiais que constituem este sistema são o concreto e o PVC. Em alguns casos, barras de aço também são utilizadas, além daquelas que fazem a ancoragem da estrutura à fundação.

O PVC ou policloreto de polivinila (também conhecido como cloreto de vinila ou policloreto de vinil) é um plástico não $100 \%$ originário do petróleo. Segundo a empresa Royal Technologies (2006b), o material usado no sistema RBS de paredes é o Royalloy ${ }^{\mathrm{TM}} \mathrm{B}$, que é uma composição complexa de resina de cloreto polivinílico, modificadores acrílicos, ceras, lubrificantes, estabilizadores de estanho (estabilizadores de chumbo não são utilizados), protetor de raios ultravioleta e supressores de chama. Ainda segundo a empresa, esse material foi desenvolvido especificamente para produzir um conjunto único de propriedades adequadas para a resistência às intempéries e desempenho do sistema. As suas propriedades físicas foram estabelecidas com base nos requisitos especificados pelo Canadian Construction Materials Centre (CCMC), tendo sido realizados diversos testes para garantir o seu atendimento.

Chahrour et al. (2005) complementam essas informações afirmando que a curva de tensão-deformação deste polímero não é linear, a sua resistência à tração é de $40 \mathrm{MPa}$ e o módulo de elasticidade é $2900 \mathrm{MPa}$.

O concreto compreende mais de $90 \%$ (em massa e volume) das paredes construídas no sistema RBS e cabe ao engenheiro ou projetista especificar o traço necessário para cada projeto específico (ROYAL TECHNOLOGIES, 2006b).

De acordo com Corsini (2011), pode ser utilizado qualquer tipo de concreto para a execução do sistema RBS, entretanto, é necessário que este material atenda a alguns requisitos para garantir o desempenho do sistema.

Para as paredes de RBS, o concreto recomendado deve ter resistência à compressão mínima de $20 \mathrm{MPa}$ (3000 psi) aos 28 dias ou $25 \mathrm{MPa}$ (3500 psi) no caso de utilização de concreto com ar incorporado, recomendado em casos de congelamento e descongelamento. Além disso, deve-se garantir que este concreto 
tenha um Slump entre 100 e 125 mm, que a relação água/ cimento não ultrapasse 0,55 em massa e que o agregado tenha um diâmetro máximo de $10 \mathrm{~mm}$ para permitir o escoamento adequado do concreto em todas as células (ROYAL TECHNOLOGIES, 2006b; CHAHROUR et al., 2005).

Segundo a Royal Technologies (2006), o concreto não segrega nas paredes de RBS devido às teias internas dos componentes de PVC, que evitam a queda livre dos agregados mais pesados. Assim, não haverá segregação do concreto se este for lançado corretamente. Segundo recomendações da empresa, o concreto normalmente não precisa ser vibrado, contudo, um martelo de borracha pode ser usado para bater nos lados das paredes para assegurar que os componentes estejam completamente preenchidos com concreto.

As barras de aço para reforço, quando utilizadas, devem ter uma tensão de escoamento mínima de $400 \mathrm{MPa}$ (60 psi). Essas barras devem ser fixadas com arames para garantir que mantenham o posicionamento correto durante a concretagem. Estes arames devem ser colocados no máximo a cada 3,0 m, sendo no mínimo dois arames por barra (ROYAL TECHNOLOGIES, 2006b).

\subsubsection{O Sistema}

O sistema RBS - Royal Building Systems foi desenvolvido no Canadá pela empresa Royal Tecnologies. Em 1998 foi construída a primeira obra com este sistema e ele está presente no Brasil desde 2002, conta Ferrari (2011).

Ainda de acordo com Ferrari (2011), o sistema é formado por perfis leves de PVC que se encaixam de maneira simples e rápida, formando paredes monolíticas preenchidas com concreto e aço. Neste modelo, os painéis de PVC atuam como fôrma, confinando o concreto que constitui a edificação e servindo de acabamento interno e externo às paredes da moradia, sem necessidade de revestimentos como pintura, cerâmica etc.

Embora o próprio PVC sirva como acabamento, Corsini (2011) lembra que este material aceita qualquer tipo de pintura ou texturização e pode, ainda, receber revestimentos cerâmicos e diversos tipos de acabamento para fachada.

Os perfis coextrudados de PVC são ocos, compostos de duas faces lisas e as laterais destes elementos têm núcleos vazados ovais que permitem o fluxo do 
concreto entre as células e proporcionam a transferência de cisalhamento nas secções compostas, esclarecem Chahrour et al. (2005).
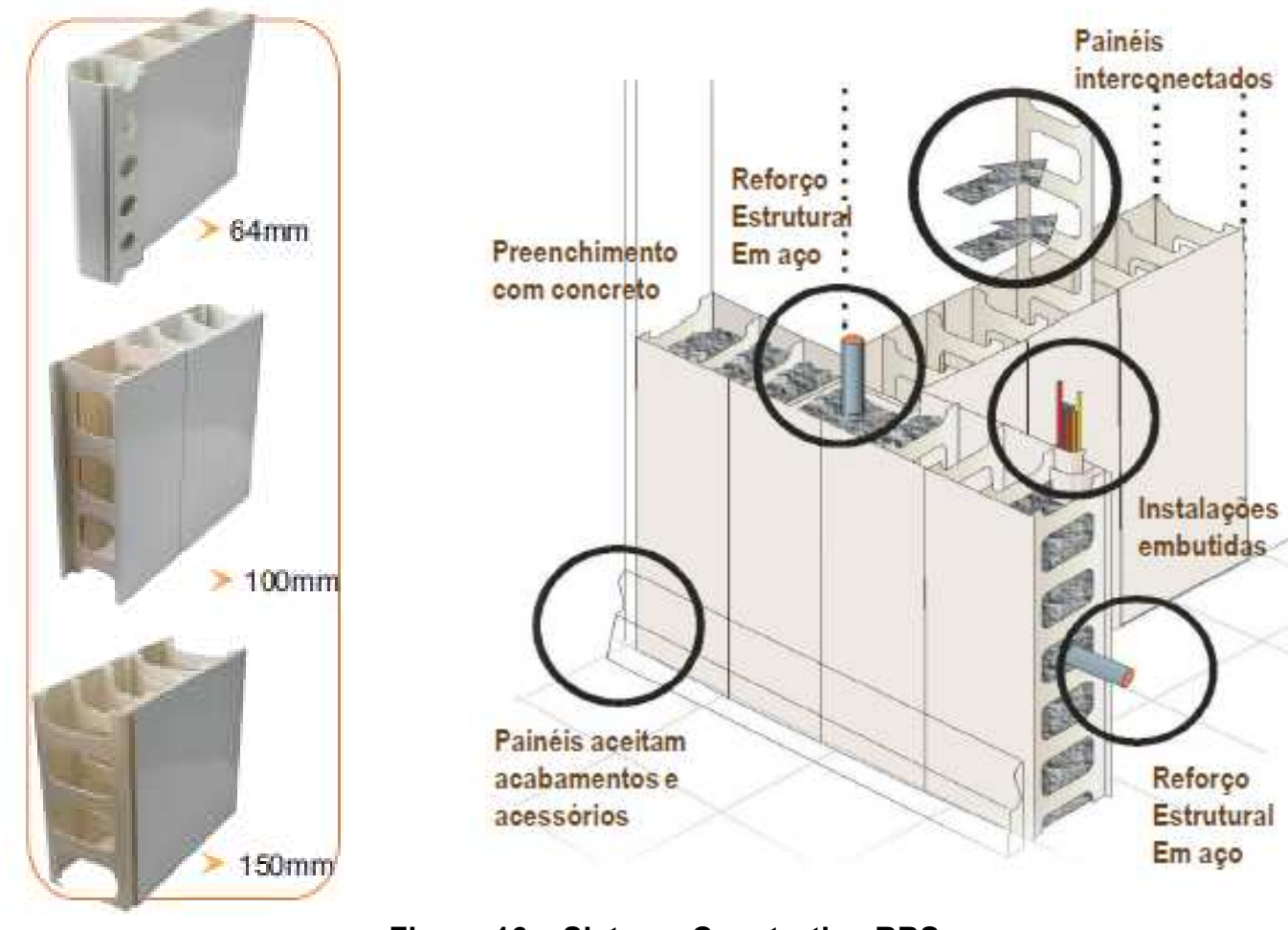

Figura 16 - Sistema Construtivo RBS

Fonte: FERRARI, 2011.

No Brasil, esses perfis são encontrados em três espessuras: 64 mm, $100 \mathrm{~mm}$ e $150 \mathrm{~mm}$, com as peles internas e externas das fôrmas de PVC com espessura mínima de 1,8 mm (FERRARI, 2011), mas existem também os perfis de $200 \mathrm{~mm}$ e $250 \mathrm{~mm}$, utilizados em regiões muito frias ou para a construção de bunkers (informação pessoal) ${ }^{6}$. De acordo com Corsini (2011), a altura das peças é definida na fabricação, de acordo com o pé-direito indicado no projeto. Assim, os perfis são personalizados para cada obra e o kit da casa vai completo e etiquetado para a montagem no canteiro.

Chahrour et al. (2005) explicam, ainda, que as paredes são formadas por dois principais elementos estruturais, os painéis (panel) e os conectores (box connector). Os painéis são componentes de uma, duas ou três células, com encaixe tipo "fêmea", e os conectores são componentes de uma célula, com encaixe tipo "macho". A figura 17, a seguir, ilustra esses elementos:

\footnotetext{
${ }^{6}$ Informação fornecida pelo $\mathrm{Arq}^{\circ}$ Tiago Ferrari via e-mail em 10/04/2013.
} 


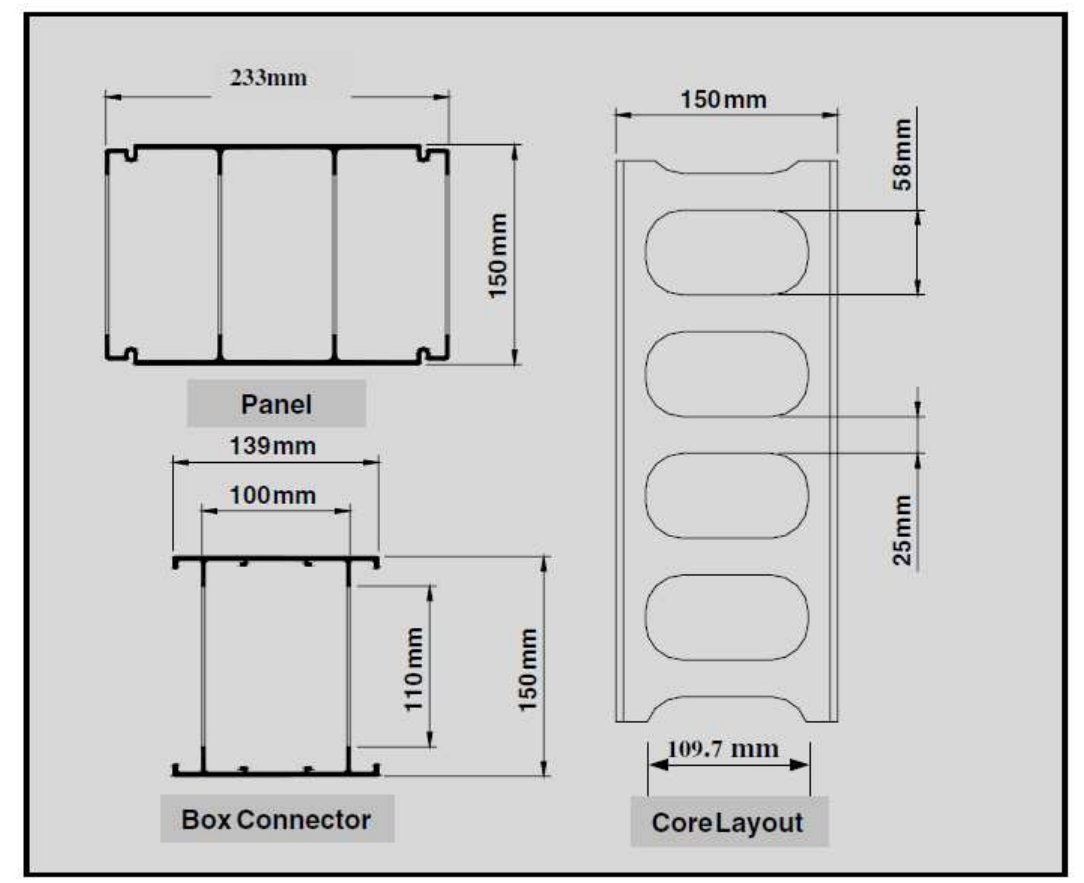

Figura 17 - Detalhamento dos painéis e conectores do sistema RBS Fonte: CHAHROUR et al., 2005.

Além destes elementos, existem, ainda, outros componentes, como os arranques (starters), conectores joiner, canais elétricos e marcos (ROYAL TECHNOLOGIES, 2006a). A figura 18, a seguir, apresenta todos os componentes para os perfis com modulação de $100 \mathrm{~mm}$, utilizados no empreendimento em questão:

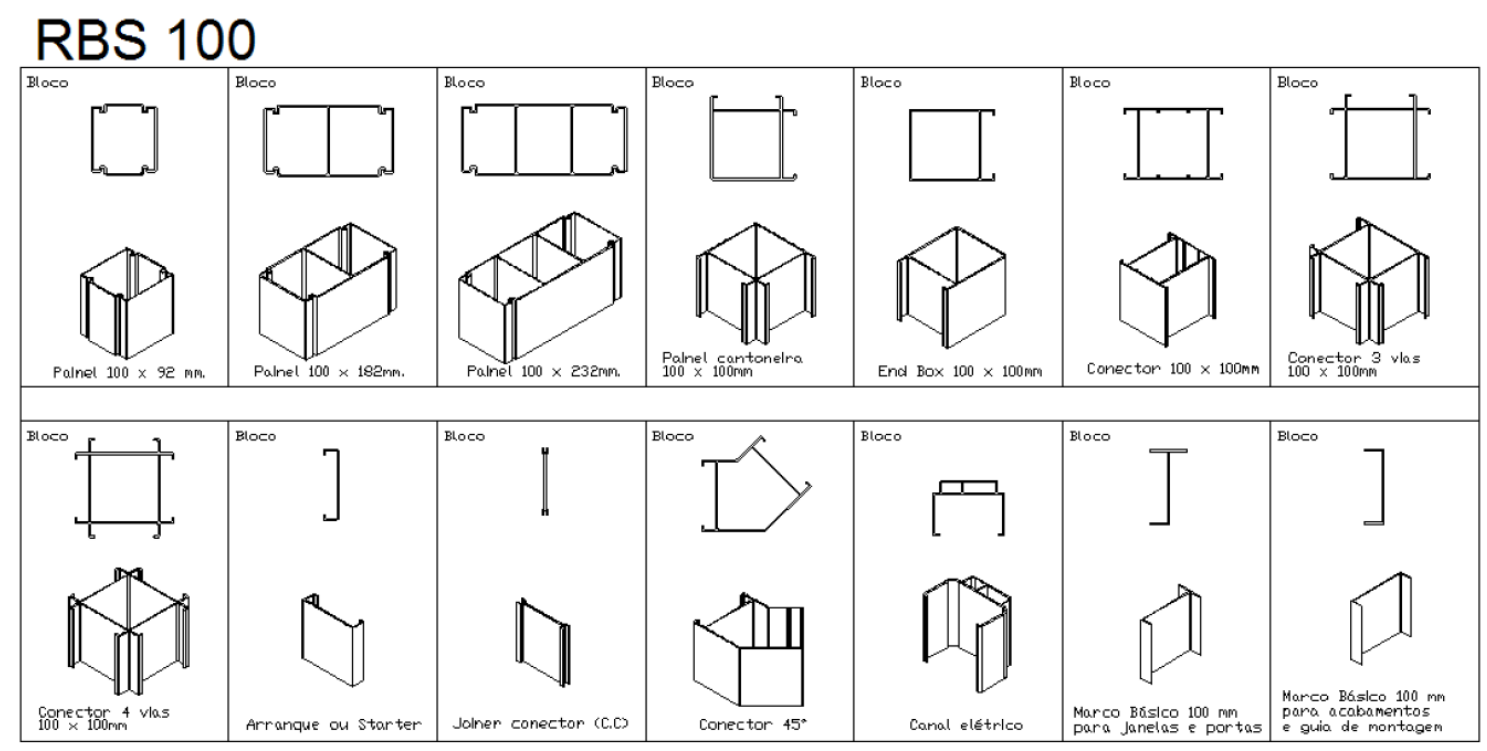

Figura 18 - Componentes do sistema RBS 100 Fonte: FERRARI, 2011. 
O sistema de montagem dos painéis é com duplo encaixe e apresenta característica autoportante no momento da montagem, ou seja, pode ser montado sem necessidade de estruturas adicionais de cimbramento (FERRARI, 2011).

Depois de montadas todas as peças, é realizada a concretagem dos perfis de PVC, o que, de acordo com Chahrour et al. (2005), cria uma parede monolítica de concreto com capacidade de cura melhorada devido ao aprisionamento de água do concreto, o que evita a secagem prematura do concreto. Estes autores afirmam, ainda, que o sistema resultante proporciona vantagens substanciais em termos de resistência estrutural e ao impacto, melhoria de durabilidade, flexibilidade de design, facilidade de construção, resistência à radiação ultravioleta e à infestação de pragas.

Ainda segundo Chahrour et al. (2005), uma das características únicas do RBS é a contribuição da fôrma permanente de polímero para o reforço da capacidade estrutural. Os autores afirmam que esta característica é validada pelo fato de que a espessura de uma parede de RBS é geralmente menor do que a espessura utilizada para uma parede convencional e, além disso, devido à sua ductibilidade e significativa resistência à tração, o polímero controla a fissuração do concreto e proporciona um reforço no caso de rompimento deste.

Outra vantagem do sistema, de acordo com Ferrari (2011), é a redução de etapas de construção, conforme ilustra a figura 19 , a seguir:

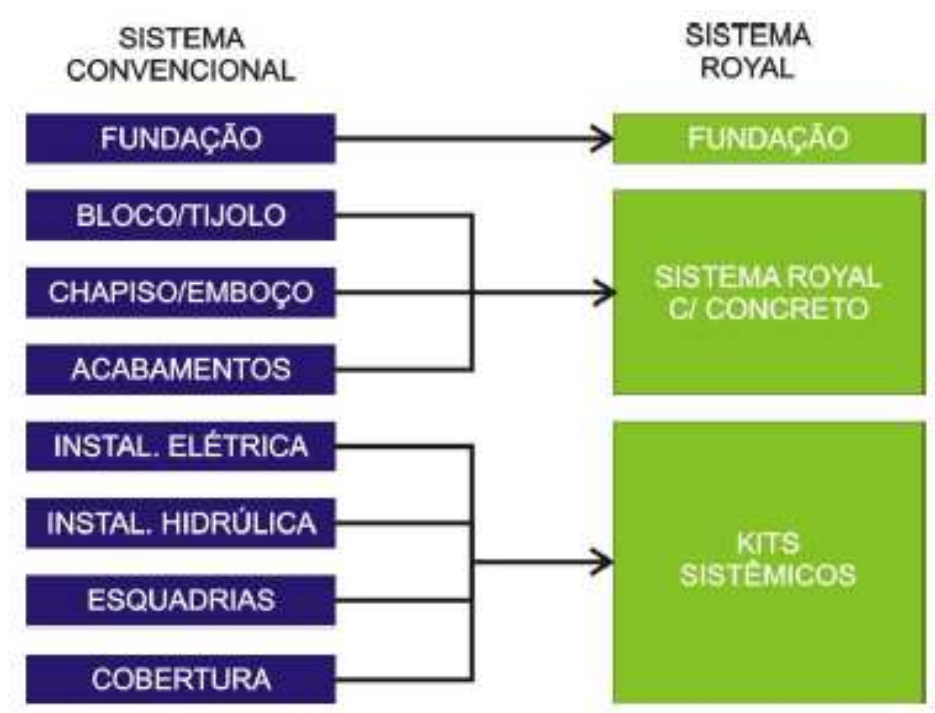

Figura 19 - Comparação de etapas entre os sistemas convencional e RBS Fonte: FERRARI, 2011. 
Os painéis, com ausência de chumbo na composição, apresentam proteção contra a ação de raios ultravioleta, evitando a alteração da cor e resistência mecânica. Esse material recebe uma garantia de 20 anos, respeitadas as condições de manutenção especificadas pelo fabricante.

Ferrari (2011) atribui o alto desempenho do sistema às características do PVC (estanqueidade, fácil limpeza, elevada durabilidade e resistência mecânica e química) e à eficiência comprovada do concreto e suas constantes melhorias técnicas.

Corsini (2011) destaca, ainda, que o PVC é resistente às intempéries e à maresia, oferece fácil limpeza e manutenção e promove adequado isolamento térmico e acústico por conta do tipo de preenchimento dos painéis e espessura das paredes.

Entre as vantagens do sistema, Ferrari (2011) destaca a alta produtividade com equipes reduzidas, que pode gerar um ganho de produtividade de até $40 \%$ no tempo total da obra. O autor também destaca a economia de até $73 \%$ no consumo de água e de até $75 \%$ no consumo de energia na obra. Somam-se a esses benefícios, segundo o autor, a limpeza e organização da obra, redução significativa do entulho e do desperdício, um melhor controle dos materiais e custos.

Cabe lembrar, porém, que se trata de um sistema inovador, ainda pouco utilizado no país, motivo pelo qual se considera interessante e importante o seu estudo, sobretudo através da avaliação pós-ocupação.

\subsubsection{Procedimentos de execução}

Ferrari (2011) enfatiza que, para que a construção das casas ocorra como em uma linha de produção, deve-se trabalhar com a utilização de kits sistêmicos. Assim, antes do início da montagem, os perfis de PVC são entregues na obra em kits já cortados na medida das paredes e etiquetados com a paginação da montagem descrita em planta. Em alguns casos podem ser entregues paredes pré-montadas. Como os perfis são leves, é fácil manuseá-los e estocá-los na obra.

Corsini (2011) alerta, ainda, para a necessidade de fiscalização do sistema, que, por ser industrializado, necessita de controle dos três itens principais: os painéis de PVC, o concreto e o sistema de cobertura. 


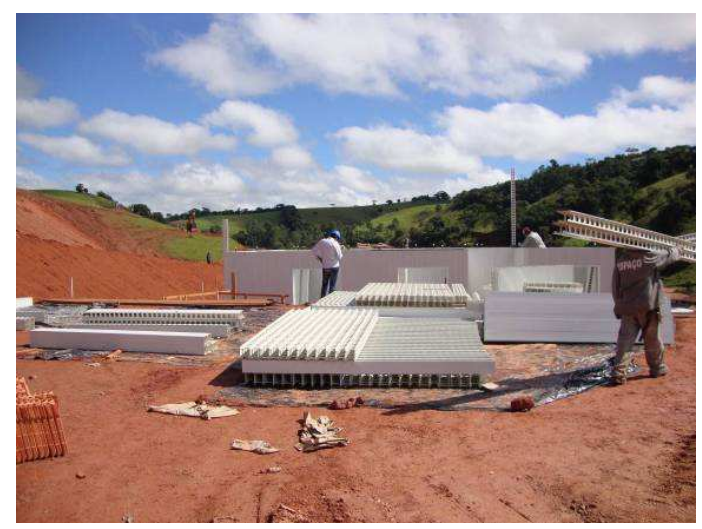

Figura 20 - Perfis separados na obra para utilização no dia Fonte: Acervo ABCP.

Segundo Ferrari (2011), a montagem das casas em São Luiz do Paraitinga seguiu as 10 etapas resumidamente descritas a seguir:

\section{Etapa 1: Execução do radier}

Execução de fundação tipo radier, deixando todas as esperas e tubulações de água, esgoto, elétrica etc.
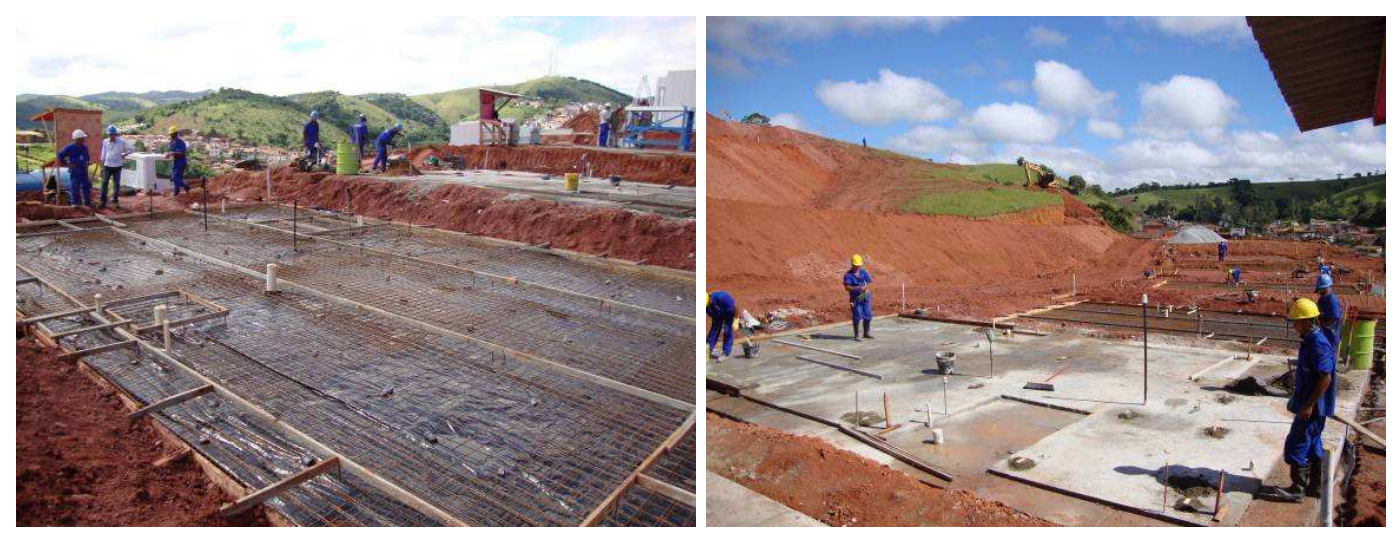

Figura 21 - Execução do radier Fonte: Acervo ABCP.

\section{Etapa 2: Fixação de ancoragens}

Sobre o radier, marcam-se os eixos das paredes que servirão de referência para a fixação de barras de aço para ancoragem das paredes. Podem ser utilizados sarrafos de madeira para marcar o local de fixação dos perfis de PVC. 

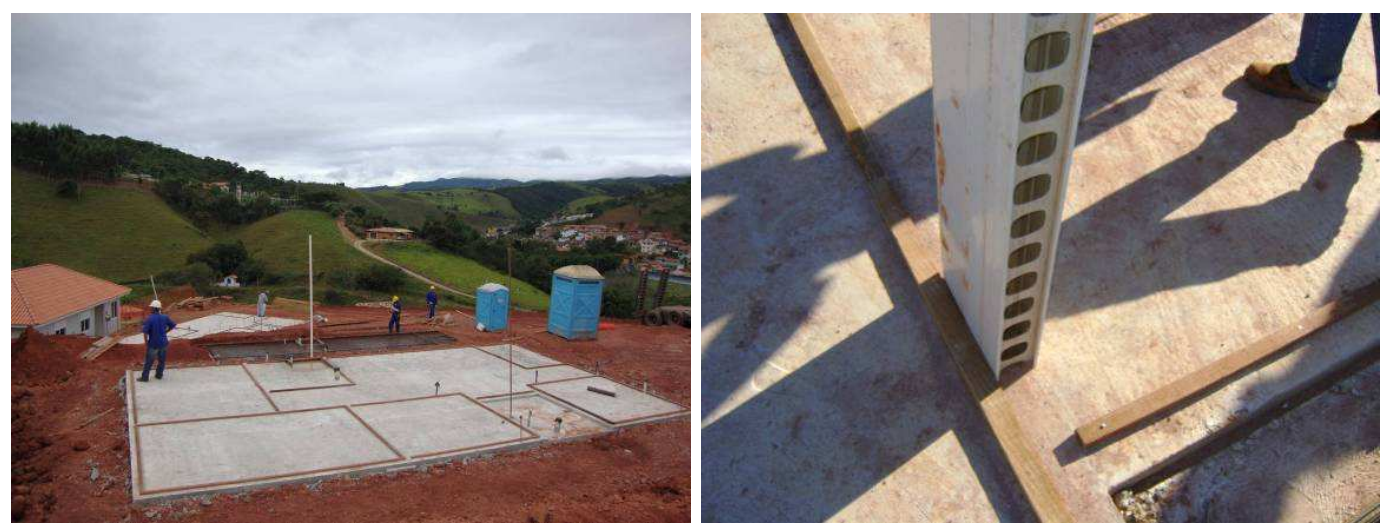

Figura 22 - Marcação dos eixos de referência no radier Fonte: Acervo ABCP.

\section{Etapa 3: Montagem das paredes}

Inicia-se, então, a montagem dos painéis de PVC, seguindo as guias de piso fixadas ao radier.
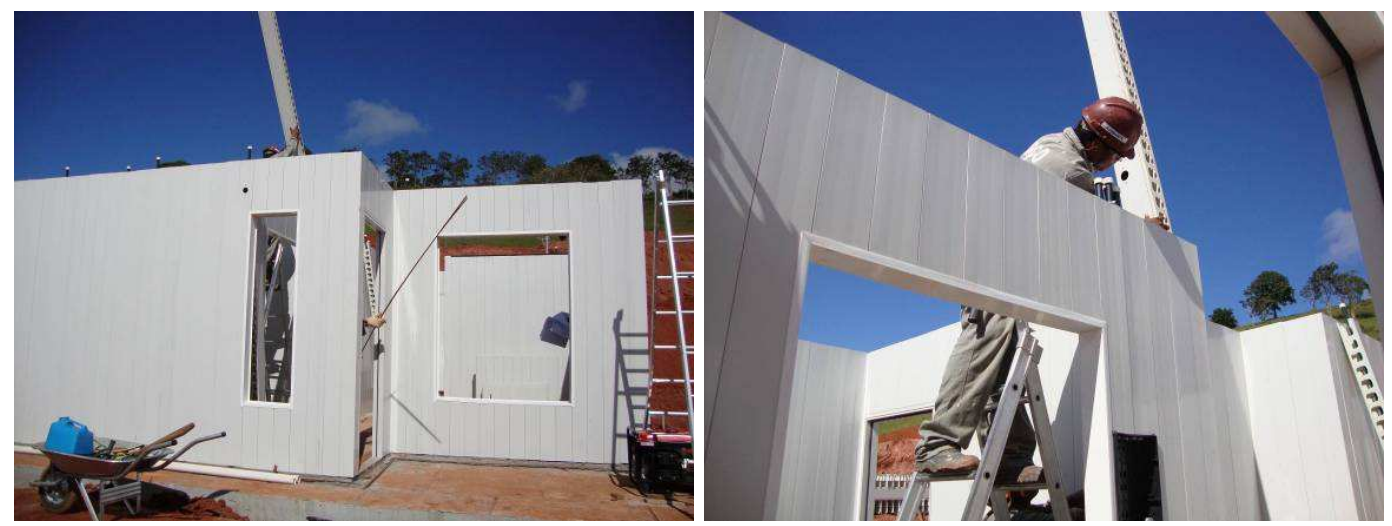

Figura 23 - Montagem dos painéis de PVC Fonte: Acervo ABCP.

\section{Etapa 4: Instalações}

Todas as tubulações hidráulicas e elétricas são embutidas nos painéis antes da concretagem, processo que pode ser realizado com as paredes deitadas sobre cavaletes ou com elas já montadas no local (CORSINI, 2011). Pontos elétricos também são embutidos nas lajes no momento de sua montagem. 

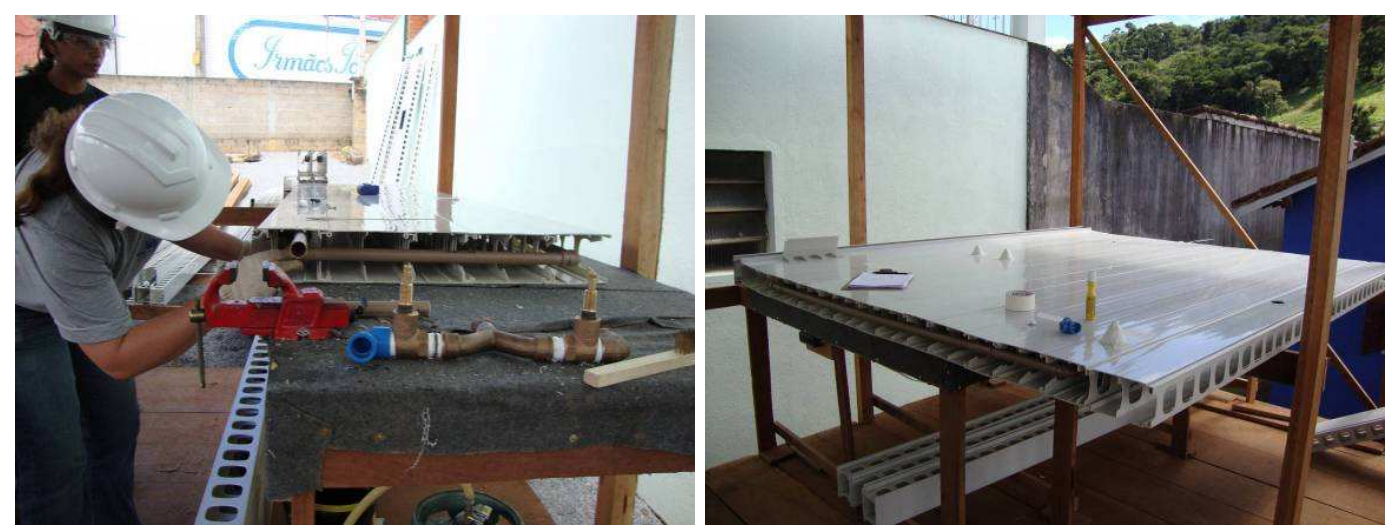

Figura 24 - Serviço de embutimento das instalações nos painéis Fonte: Acervo ABCP.

\section{Etapa 5: Escoramento e alinhamento}

Após a montagem completa do kit de PVC, faz-se o escoramento interno e externo das paredes com auxílio de sarrafos e escoras de madeira, o que serve para definir o prumo e alinhamento dos painéis plásticos e mantê-los posicionados durante a concretagem (CORSINI, 2011).
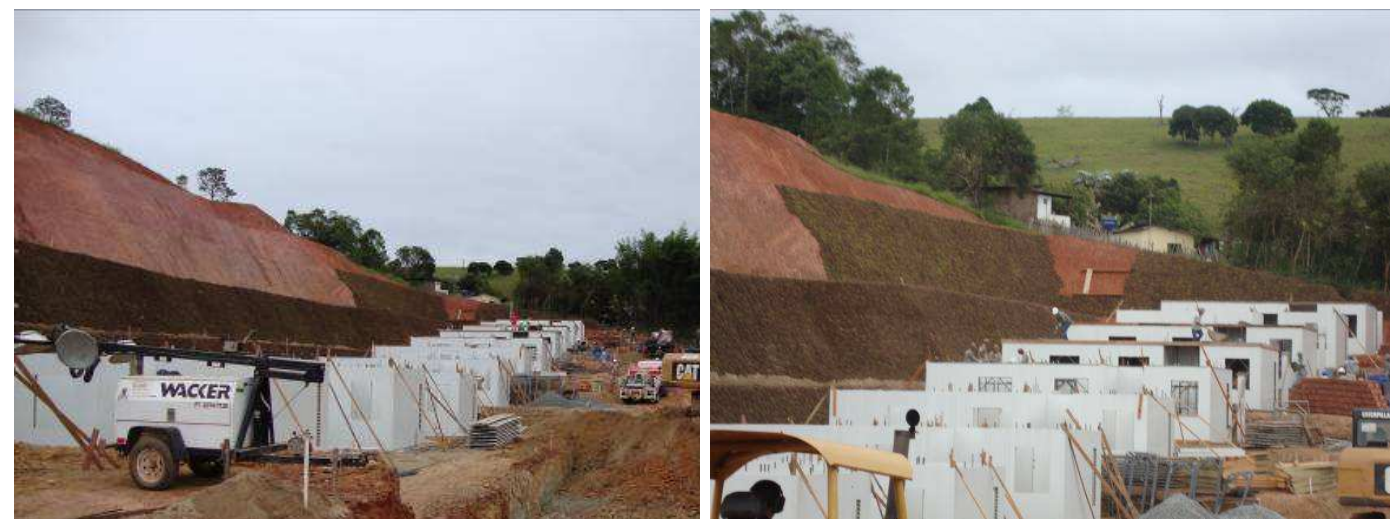

Figura 25 - Vista dos painéis de PVC escorados Fonte: Acervo ABCP.

\section{Etapa 6: Concretagem}

Após a colocação do escoramento, as paredes são concretadas com cautela e lentidão para que o material flua entre as fôrmas, evitando estufamento, principalmente no acabamento das portas e janelas. Segundo Corsini (2011), as fôrmas devem ser concretadas em camadas de $50 \mathrm{~cm}$ a $70 \mathrm{~cm}$, conforme ilustra a figura 26 , a seguir: 

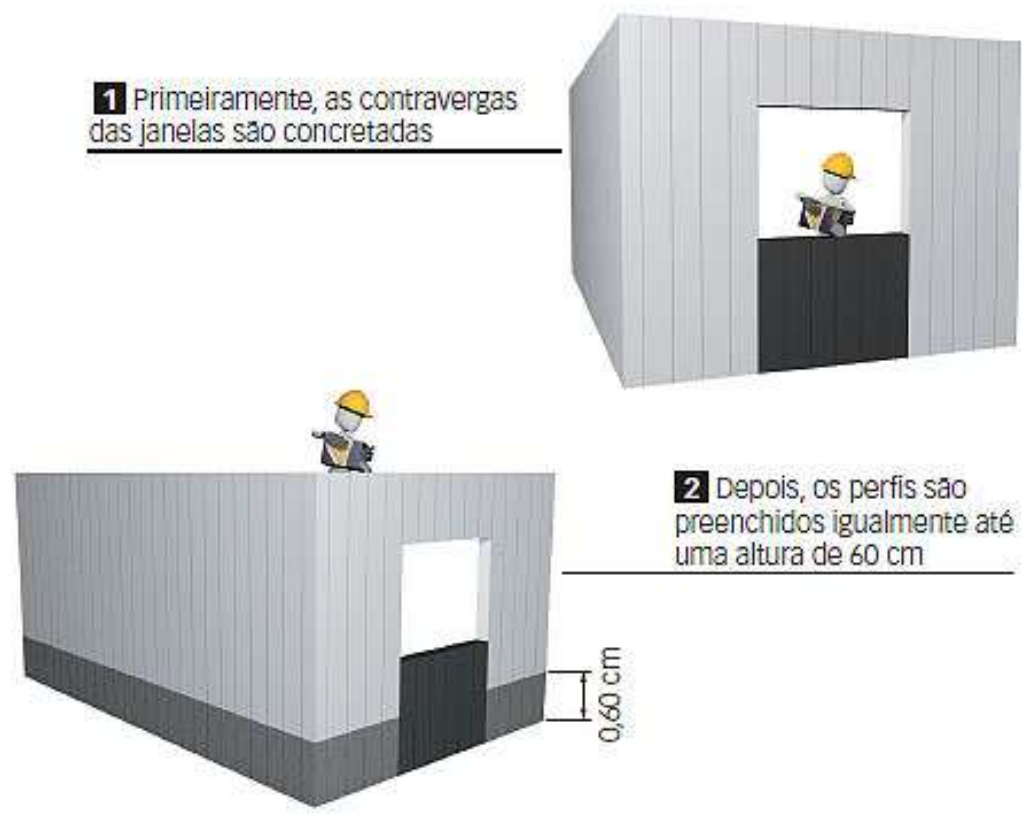

2 Depois, os perfis são preenchidos igualmente até uma altura de $60 \mathrm{~cm}$

3 Em seguida, a concretagem é retomada do ponto inicial para uma nova camada
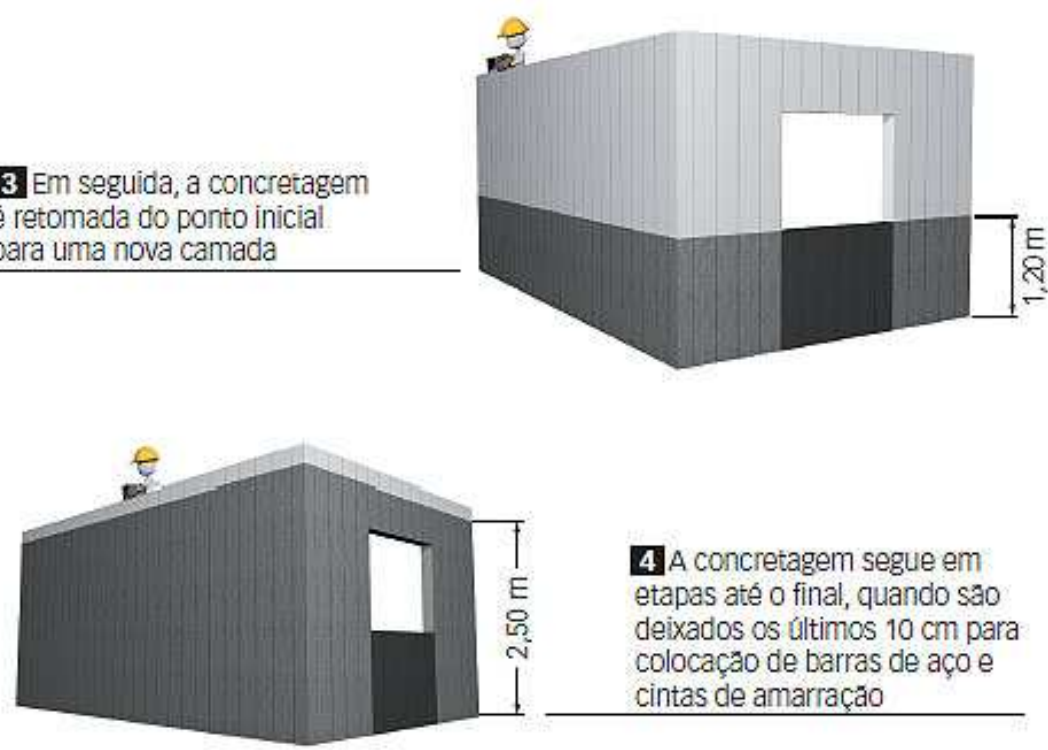

4 A concretagem segue em etapas até o final, quando sao deixados os últimos $10 \mathrm{~cm}$ para colocaça de barras de aço e cintas de amarraçăo

5. Após colocaçăo das barras de cintas, e da ancoragem para a estrutura de cobertura, é feito o preenchimento final com o concreto

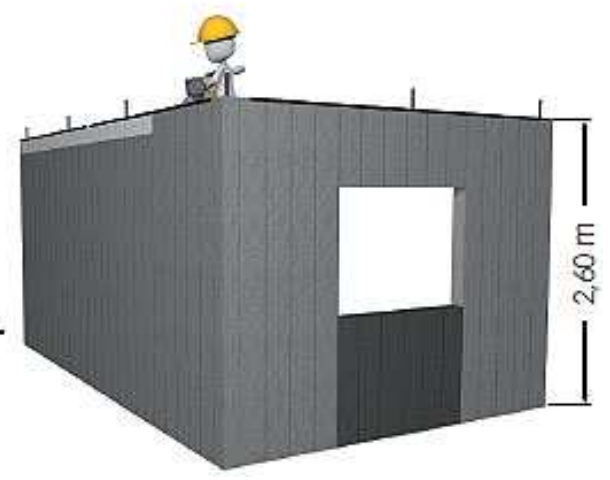

Figura 26 - Etapas de concretagem do Sistema RBS Fonte: CORSINI, 2011. 


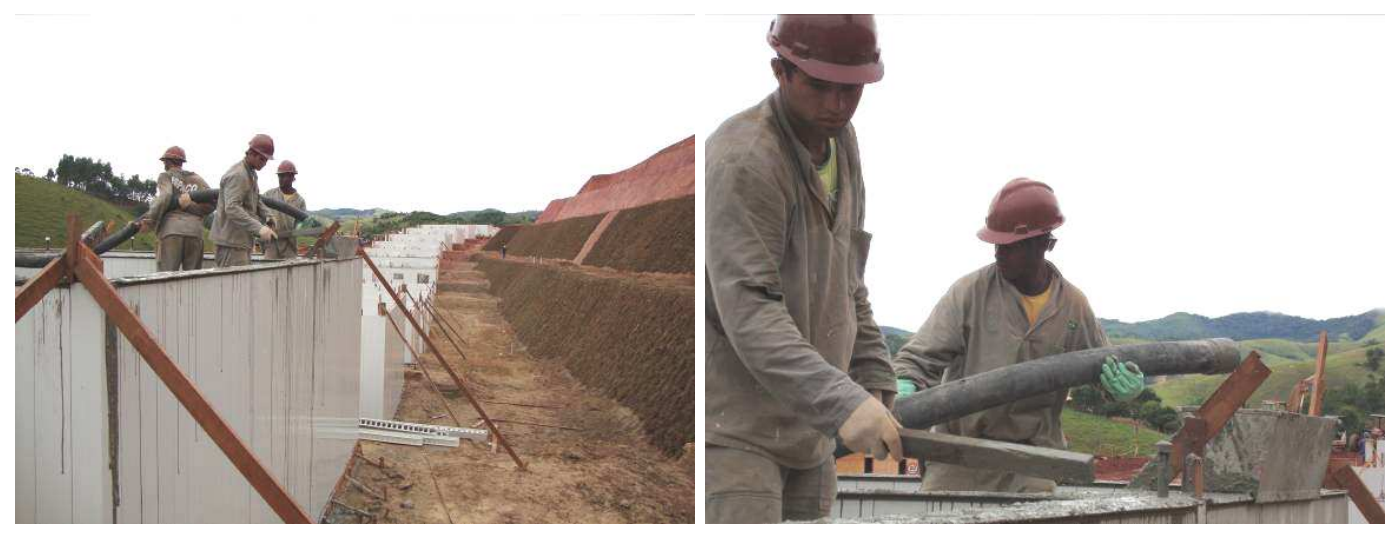

Figura 27 - Concretagem dos painéis de PVC ainda escorados

Fonte: Acervo ABCP.

\section{Etapa 7: Montagem da laje}

Podem ser utilizadas lajes moldadas in loco ou pré-moldadas, que devem ser apoiadas sobre as paredes já concretadas.

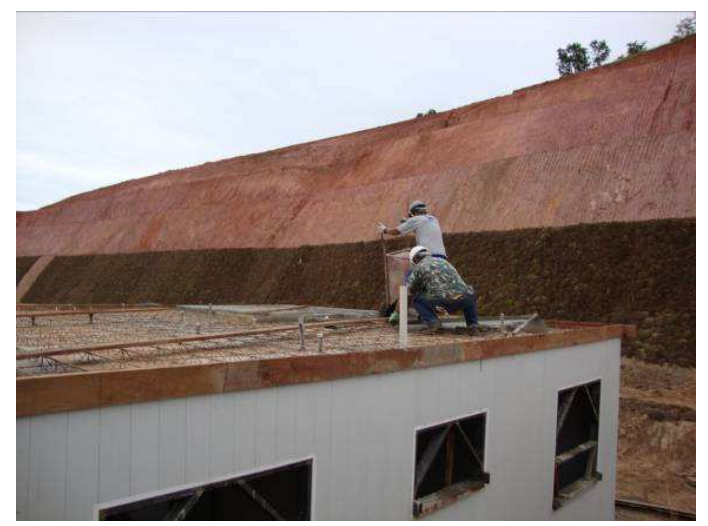

Figura 28 - Concretagem da laje pré-moldada Fonte: Acervo ABCP.

\section{Etapa 8: Estrutura da cobertura e piso}

A estrutura da cobertura pode ser metálica ou em madeira, apoiada sobre a laje ou sobre as paredes, sendo que no caso de São Luiz do Paraitinga foi utilizada estrutura de madeira. Paralelamente, outra equipe executa os pisos no interior da casa. 


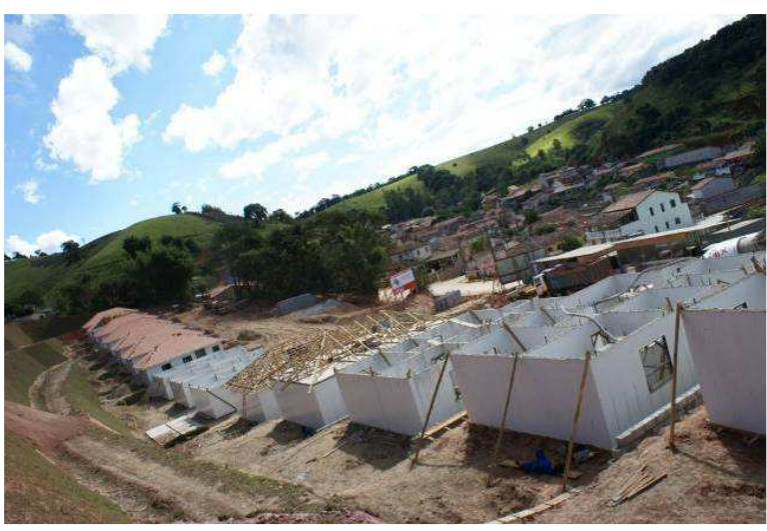

Figura 29 - Montagem da estrutura da cobertura Fonte: Acervo ABCP.

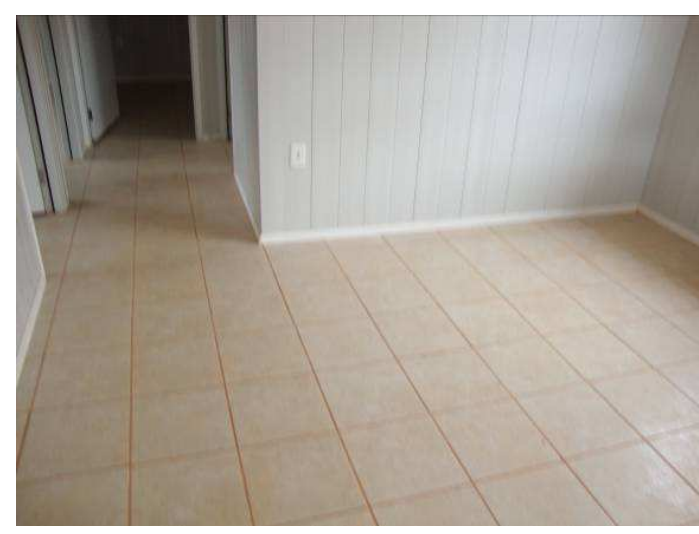

Figura 30 - Piso cerâmico recém-aplicado Fonte: Acervo ABCP.

\section{Etapa 9: Telhamento e kit solar}

Uma vez terminada a estrutura, são instaladas as telhas, todo o acabamento do telhado e o sistema de aquecimento solar.

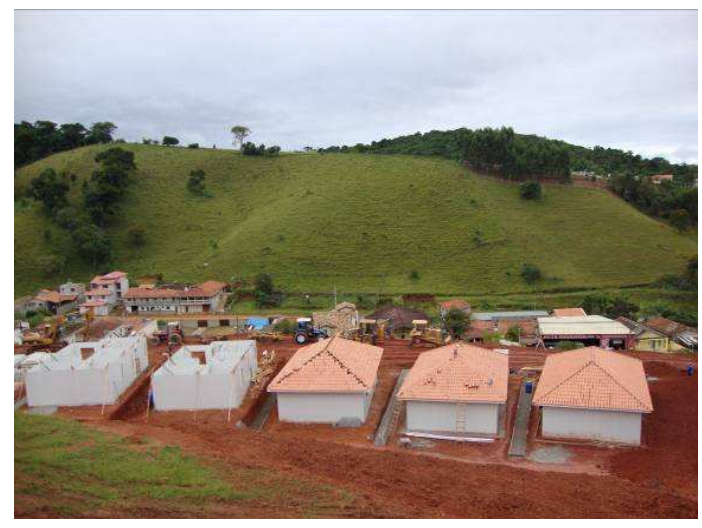

Figura 31 - Execução do telhamento Fonte: Acervo ABCP.

\section{Etapa 10: Esquadrias e acabamentos}

Por fim, são instaladas as esquadrias, louças, metais, fiação e arremates. 


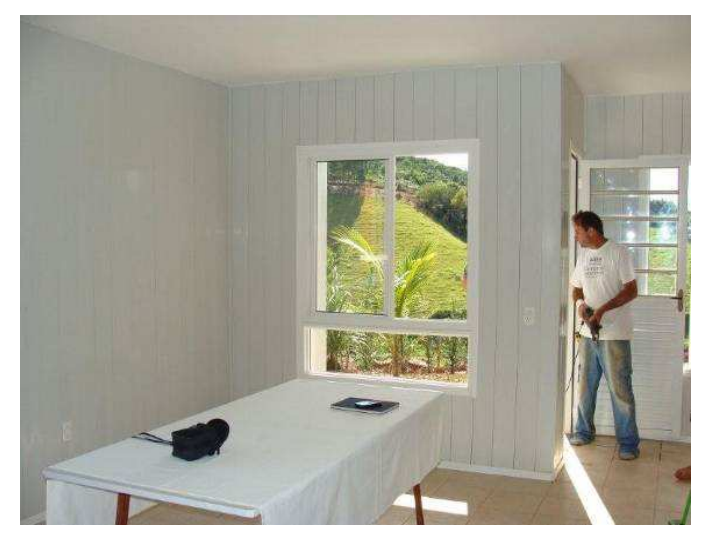

Figura 32 - Instalação das esquadrias Fonte: Acervo ABCP.

Ainda de acordo com Ferrari (2011), a execução de cada uma das casas térreas em São Luiz do Paraitinga, com $65 \mathrm{~m}^{2}$ de área útil, foi executada em 11 dias.

\subsubsection{Aplicação em moradia popular}

De acordo com Ferrari (2011), o sistema RBS pode ser utilizado para construção de residências e prédios de até 5 pavimentos em diversos padrões, podendo ser utilizado na construção de casas e edifícios residenciais, industriais, comerciais, escolas, hospitais etc. Corsini (2011) afirma, ainda, que a quantidade de pavimentos pode variar bastante, mesmo em casas populares, pois o que determina a quantidade de pavimentos é a resistência do concreto.

No Brasil, essa tecnologia está sendo aplicada principalmente na construção de moradias populares, sendo utilizada já há alguns anos no Rio Grande do Sul. Desde 2010, tem sido adotada pela CDHU, sendo o caso de São Luiz do Paraitinga, até agora, o caso de maior aplicação em larga escala da tecnologia de concreto em PVC no país (CORSINI, 2011).

A espessura dos painéis é um dos principais fatores que influencia o custo do projeto. Segundo o arquiteto Tiago Ferrari, da Royal Technologies do Brasil, as principais tipologias de projeto executadas no país são de casas de interesse social, onde são utilizados perfis de $64 \mathrm{~mm}$ de espessura, que é o indicado para projetos de moradias de até $50 \mathrm{~m}^{2}$. Com essa espessura, há um ganho também em área útil, sendo que em uma casa de $37 \mathrm{~m}^{2}$, se ganha quase $2 \mathrm{~m}^{2}$ de área útil (CORSINI, 2011). Além disso, Corsini (2011) salienta que, como o sistema quase não produz resíduos no canteiro, não requer muitos equipamentos ou ferramentas, dispensa 
custos com revestimentos das paredes e permite calcular com precisão o gasto com concreto, o custo de construção das casas pode ser reduzido.

Além do custo competitivo, uma característica do sistema que favorece seu uso na construção de casas populares é a velocidade de montagem, já que se trata de um sistema construtivo industrializado. Segundo Ferrari, é possível se obter uma produtividade de $42 \mathrm{~min} / \mathrm{m}^{2}$ para ter a parede pronta, já com concreto (CORSINI, 2011).

\subsection{O Estudo de Caso}

Embora já tenha sido realizada uma avaliação de satisfação neste empreendimento, os dados apresentados por Ferrari (2011) levam em consideração apenas a percepção dos usuários, sem nenhum tipo de avaliação técnica. Assim, em virtude das características especiais deste empreendimento, com especial atenção à utilização de um sistema construtivo inovador, considerou-se interessante e viável a realização de uma APO mais detalhada.

Para a realização desta pesquisa, foram realizadas duas visitas ao empreendimento São Luiz do Paraitinga "C" com o intuito de entrevistar os moradores e colher informações sobre as casas e modificações realizadas após a entrega destas pela CDHU, sendo que cada uma dessas visitas contou com a participação de duas pessoas.

Durante as visitas, foi selecionada uma amostra de 12 casas, escolhidas de acordo com os critérios já apresentados. Foram selecionadas casas nas três ruas do empreendimento, em diferentes posições com relação ao Sol, à proximidade com os taludes e em níveis de altitude diferentes. As 12 unidades habitacionais visitadas foram nomeadas com a sigla SLP, que identifica o empreendimento, e os números de 01 a 12. Assim, cada uma delas recebeu um nome de SLP01 a SLP12, seguindo a ordem de realização das visitas.

As visitas foram realizadas em dois dias distintos, sendo que nas duas ocasiões a temperatura estava elevada, com cerca de $33^{\circ}$ e $31^{\circ}$, respectivamente. É importante relatar, também, que não choveu nas datas das visitas e nem no dia anterior à realização destas. 


\subsubsection{Apresentação e Análise dos Resultados das Entrevistas}

As entrevistas com os moradores foram realizadas de acordo com o formulário apresentado no Apêndice $B$.

Através delas foi possível verificar que o número de moradores varia entre $3 \mathrm{e}$ 7 por residência, gerando uma média de 5,5 moradores por unidade nas casas visitadas, sendo que todas elas ainda estão financiadas.

Além disso, verificou-se que todas as famílias entrevistadas moram no imóvel desde a entrega, ou seja, todas são as primeiras donas dos imóveis.

Foi possível, também, observar que todas as residências contam com os bens de consumo básicos, como fogão, geladeira, televisão e chuveiro elétrico. É importante lembrar, no entanto, que todas as casas possuem sistema de aquecedor solar de água, o que reduz ou dispensa a utilização de aquecimento por energia elétrica. O gráfico abaixo apresenta a porcentagem de famílias que possui cada bem de consumo:

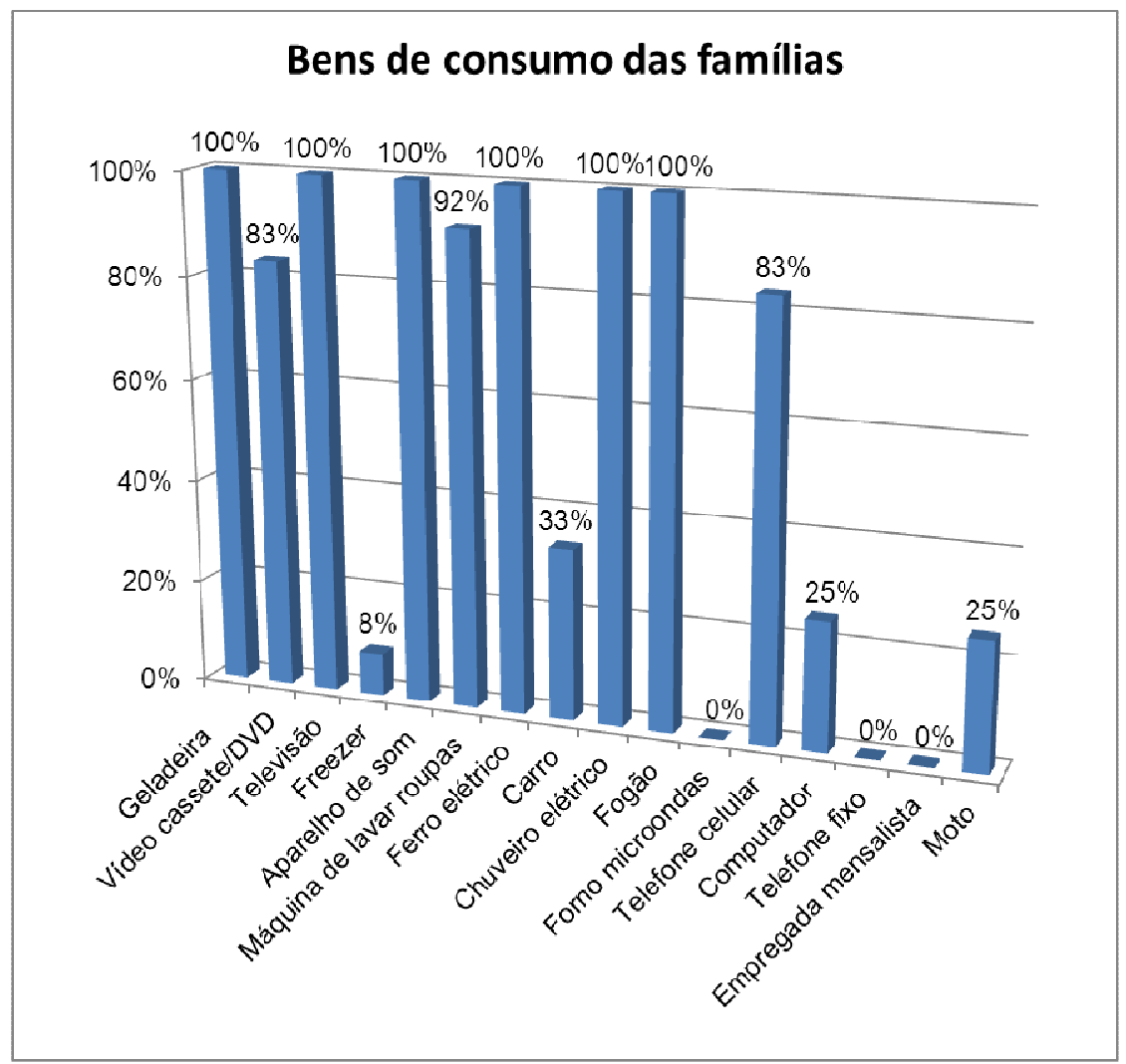

Gráfico 1 - Estudo de Caso 1: Bens de consumo das famílias 
No geral, a avaliação da casa entregue foi muito boa, sendo que $92 \%$ dos entrevistados consideram que a casa foi entregue completa e $75 \%$ consideram que a casa entregue atende a todas as necessidades da família. Dentre os que consideram que a casa não foi entregue completa, contou muito o fato de a casa ter sido entregue sem muro e portão. Já aqueles que afirmam que a casa não atende às necessidades da família reclamam do tamanho da cozinha, que eles consideram muito pequena e inadequada.

Os demais moradores afirmam gostar da casa por ter um bom tamanho, não precisar de pintura, ser fácil de limpar e ter uma boa aparência interna e externa. A grande maioria acredita que está morando muito melhor do que morava antes e alguns demonstraram até certo constrangimento em apontar falhas nas casas.

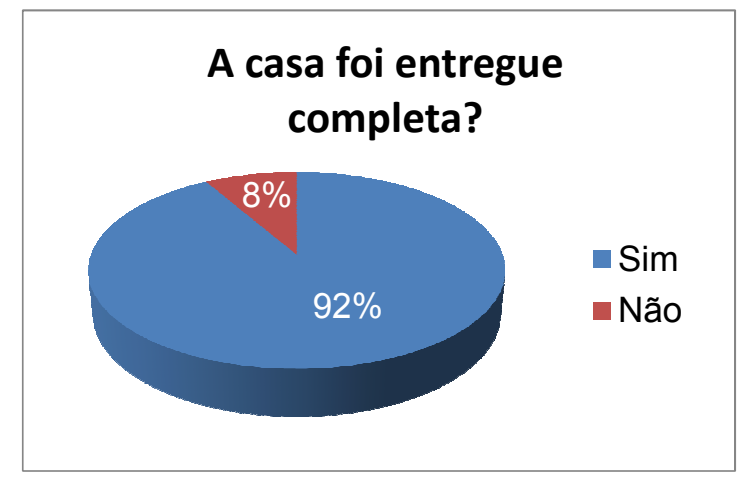

Gráfico 2 - Estudo de Caso 1: Avaliação da casa recebida

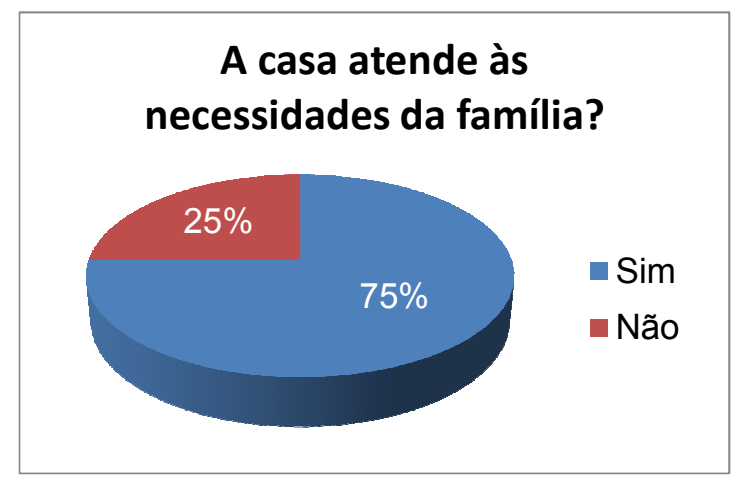

Gráfico 3 - Estudo de Caso 1: Atendimento às necessidades

Com relação à ocorrência de problemas construtivos e patologias, $83 \%$ dos moradores dizem ter tido algum tipo de problema com a casa, problemas estes que vão desde coisas simples, como a falta de vedação dos vasos sanitários, até a ocorrência de infiltração nas paredes e lajes.

Do total de casas visitadas, $58 \%$ apresentam problemas com umidade e infiltração, no entanto, nenhum morador relatou a presença de mofo nas lajes e paredes. 


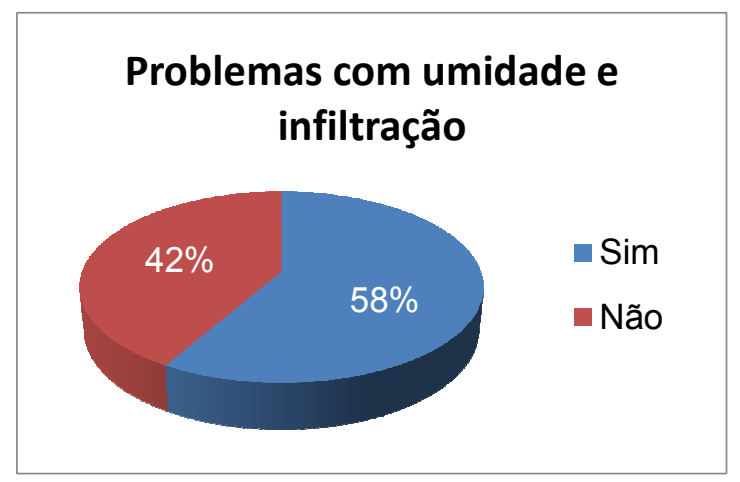

Gráfico 4 - Estudo de Caso 1: Problemas com umidade e infiltração

Dentre os moradores que relataram problemas com umidade e infiltração, todos afirmam que o problema está nas lajes ou no topo das paredes.

Já com relação à iluminação e ventilação, as avaliações dos moradores foram muito boas, chegando a $75 \%$ de avaliações ótimas nos dois quesitos, como mostram os gráficos 5 e 6 a seguir:

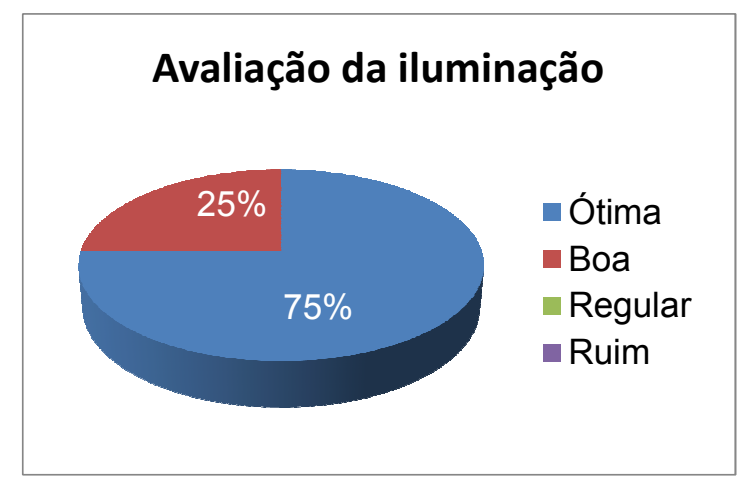

Gráfico 5 - Estudo de Caso 1: Avaliação da iluminação

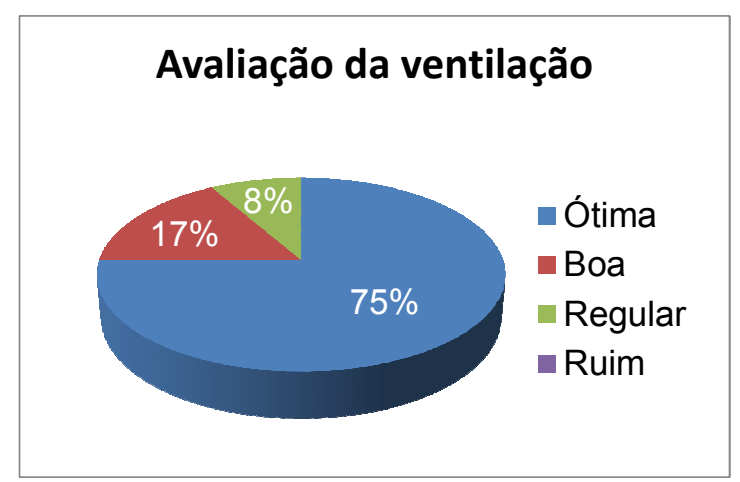

Gráfico 6 - Estudo de Caso 1: Avaliação da ventilação

Ainda assim, mesmo a avaliação da casa recebida tendo sido muito boa, observou-se que a grande maioria das famílias fez algum tipo de modificação, sendo que a maioria diz respeito a mudanças no lote e não na casa em si. 


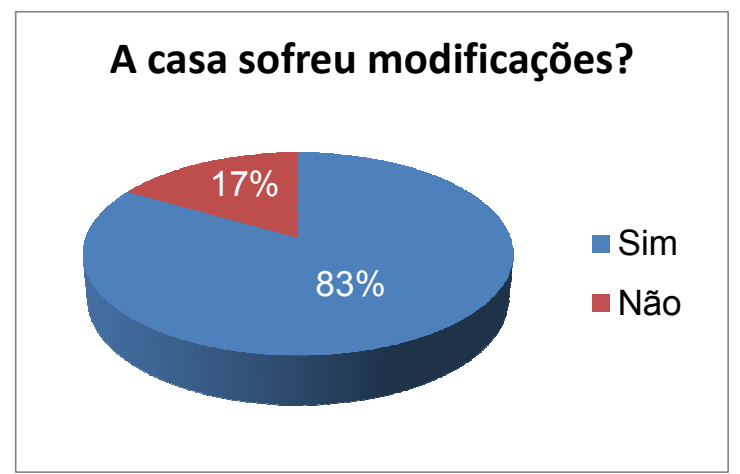

Gráfico 7 - Estudo de Caso 1: Porcentagem de casas modificadas

Dentre os moradores que realizaram modificações na residência, $80 \%$ afirmaram que seguiram um projeto fornecido pela $\mathrm{CDHU}$ e o restante declara não ter utilizado projeto, como indica o gráfico 8 :

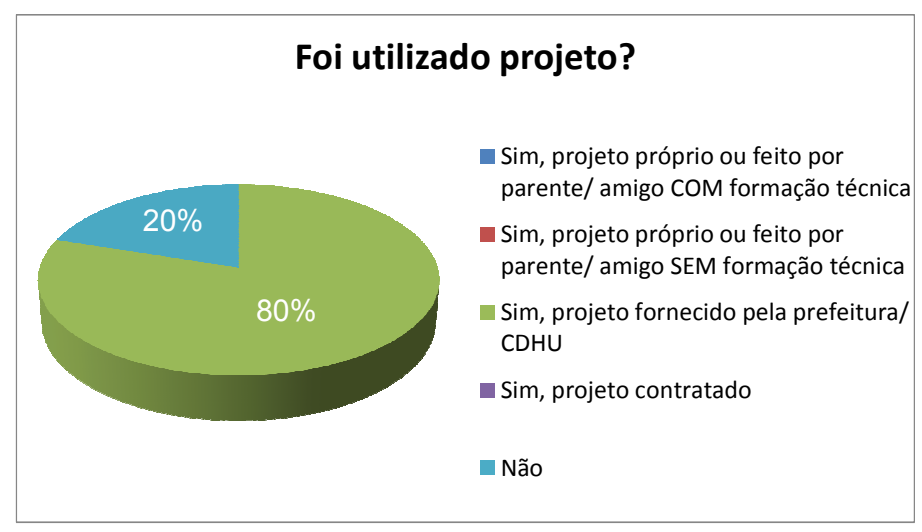

Gráfico 8 - Estudo de Caso 1: Uso de projeto para realizar modificações

Há de se explicar, no entanto, que não foi fornecido um projeto para realização das modificações, mas sim regras e orientações. A principal regra citada pelos moradores diz respeito aos muros, que não devem ultrapassar os 2 metros de altura, e os portões, que não podem ser totalmente fechados, ou seja, devem ter elementos vazados. Outra orientação citada pelos moradores foi quanto à área que pode ser ocupada nos fundos do lote, que, segundo eles, compreende toda a área da casa até o muro de fundo.

Observou-se, também, que em $60 \%$ dos casos as modificações foram realizadas por pedreiros contratados e que as modificações vêm acontecendo espaçadamente ao longo do tempo, como mostram os gráficos 9 e 10 a seguir: 


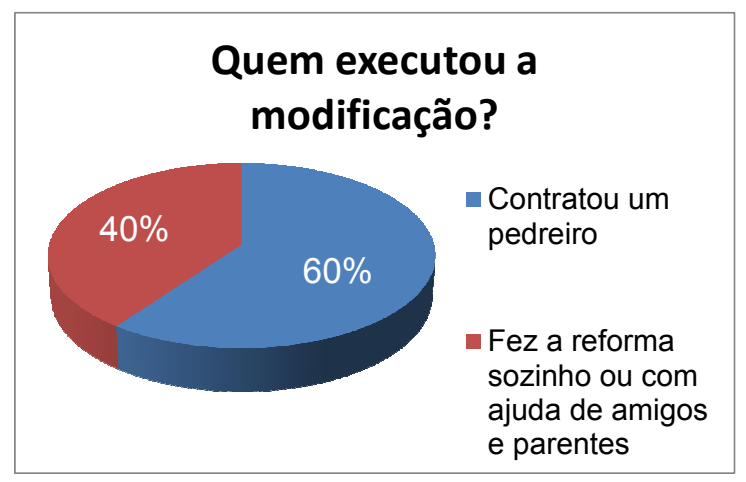

Gráfico 9 - Estudo de Caso 1: Agente realizador das modificações

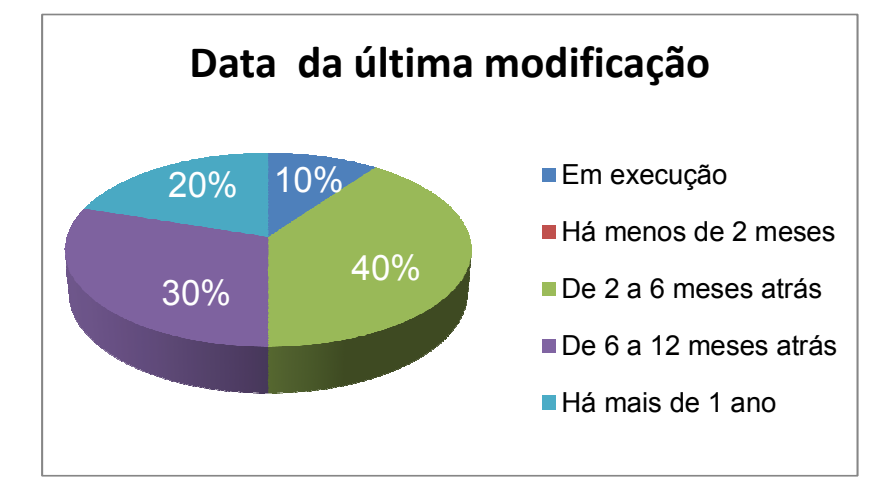

Gráfico 10 - Estudo de Caso 1: Data da última modificação

Metade dessas famílias fez modificações em pelo menos um dos dormitórios, no banheiro, na área de serviço e na garagem e menos da metade modificou a sala e a cozinha, como indica o gráfico 11, a seguir:

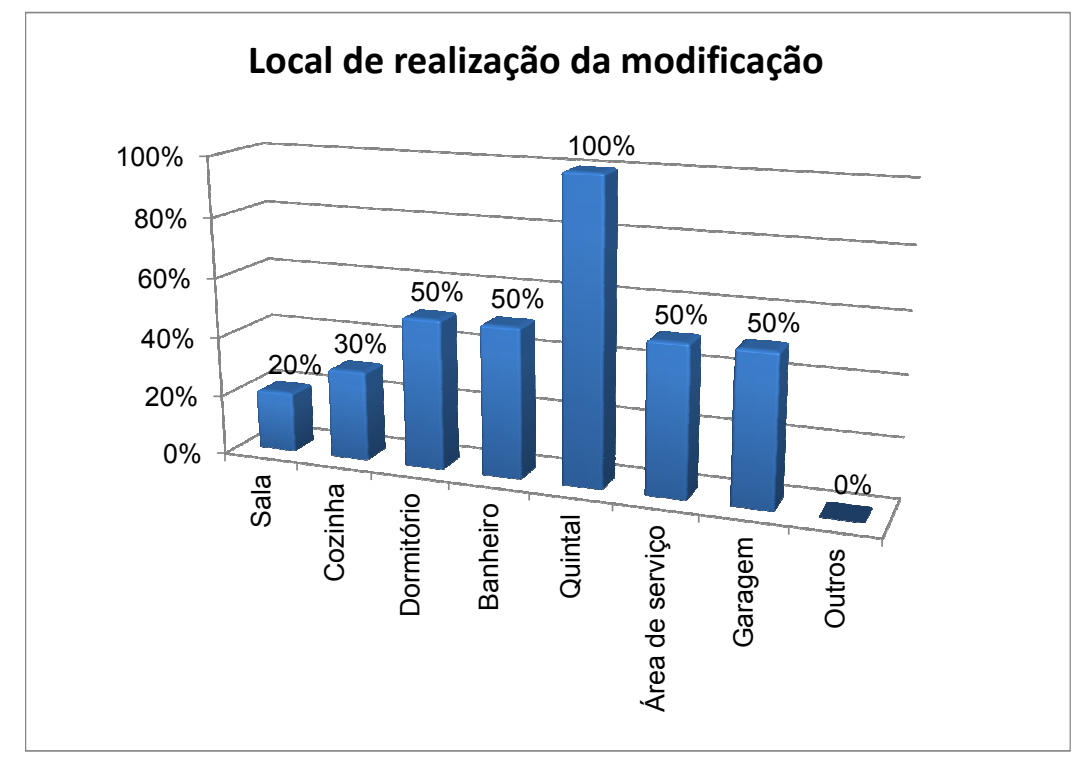

Gráfico 11 - Estudo de Caso 1: Local de realização das modificações 


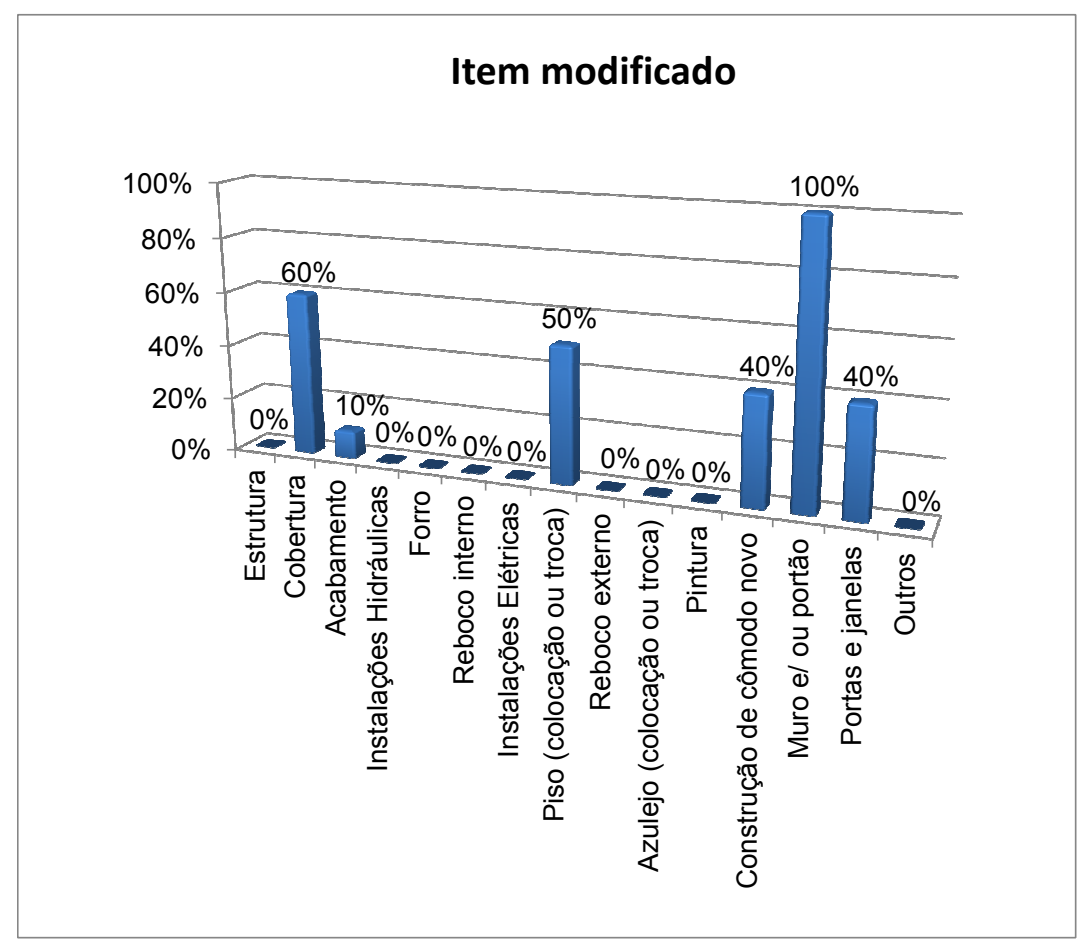

Gráfico 12 - Estudo de Caso 1: Itens modificados

Dentre os moradores que afirmaram já ter realizado alguma modificação na residência, todos eles garantiram que não enfrentaram dificuldades de ordem técnica para a sua execução.

Quando perguntados se têm a intenção de realizar alguma modificação na casa futuramente, $75 \%$ dos entrevistados afirmaram que SIM, sendo que os $25 \%$ que responderam NÃO já realizaram modificações. É interessante observar, também, que $58 \%$ dessas famílias já realizaram alguma modificação no imóvel, mas ainda tem a intenção de modificá-lo ainda mais. Assim, percebe-se que 100\% dos entrevistados já realizaram ou pretendem realizar modificações nas casas recebidas da CDHU, como mostra o gráfico 13. 


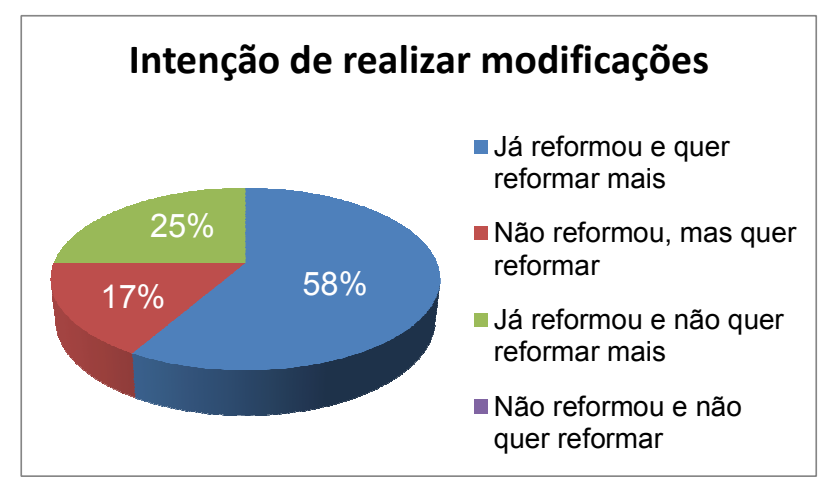

Gráfico 13 - Estudo de Caso 1: Intenção de modificar o imóvel

Dos moradores que pretendem realizar modificações, $22 \%$ consideram que a reforma é urgente.

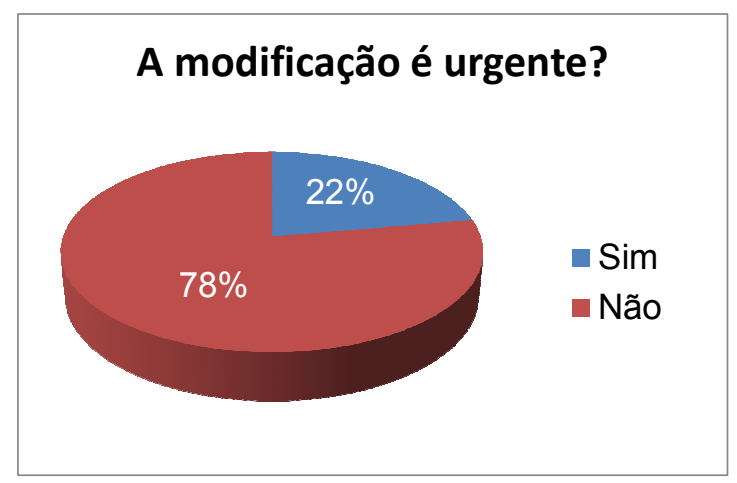

Gráfico 14 - Estudo de Caso 1: Urgência das modificações

A principal intenção dos moradores é a construção de um cômodo novo, sendo citada por $50 \%$ dos entrevistados, que relataram o desejo de construir um dormitório ou uma área de serviço nos fundos do lote. Alguns entrevistados relataram também o desejo de trocar o piso da casa futuramente e fazer uma cobertura para a garagem ou para estender roupas. Duas famílias relataram a intenção de modificar os muros e portões. A primeira dessas famílias ainda não construiu nenhum tipo de muro ou portão e tem a preocupação com a segurança como principal motivador para a execução destes. A outra família já construiu o muro da frente e pretende finalizar o portão, além de aumentar os muros laterais para dar mais privacidade à família, uma vez que as janelas são alinhadas com as janelas da casa vizinha. 
Os gráficos 15 e 16 mostram as intenções dos moradores quanto às novas modificações a serem realizadas, destacando os ambientes a serem modificados e o tipo de serviço a ser executado, respectivamente.

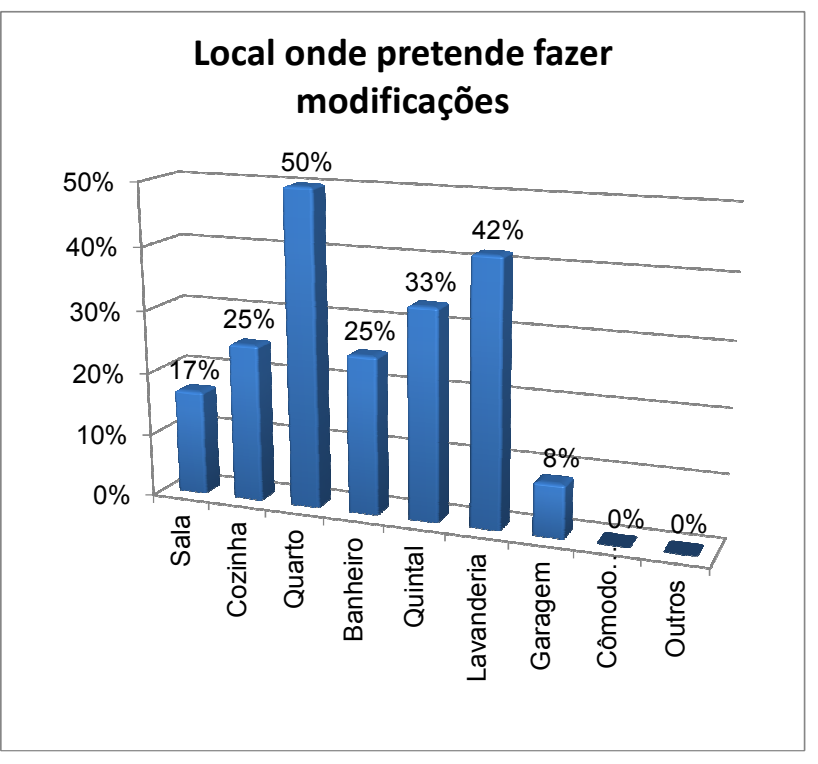

Gráfico 15 - Estudo de Caso 1: Local que pretende modificar

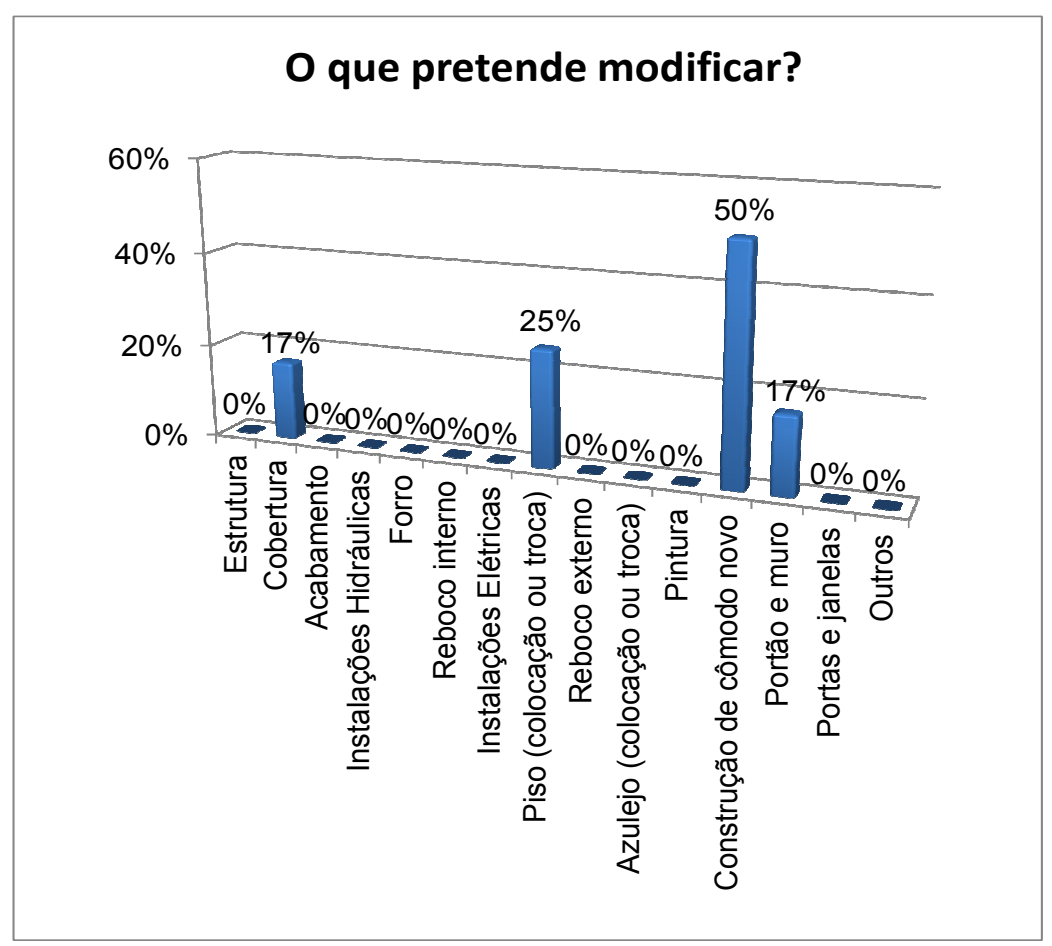

Gráfico 16 - Estudo de Caso 1: Serviço que pretende realizar 
Quando perguntados sobre os benefícios das modificações para a família, realizadas ou intencionadas, a maioria dos entrevistados citou a ampliação da casa, seguida pelo conforto e segurança, além dos outros itens indicados no gráfico a seguir:

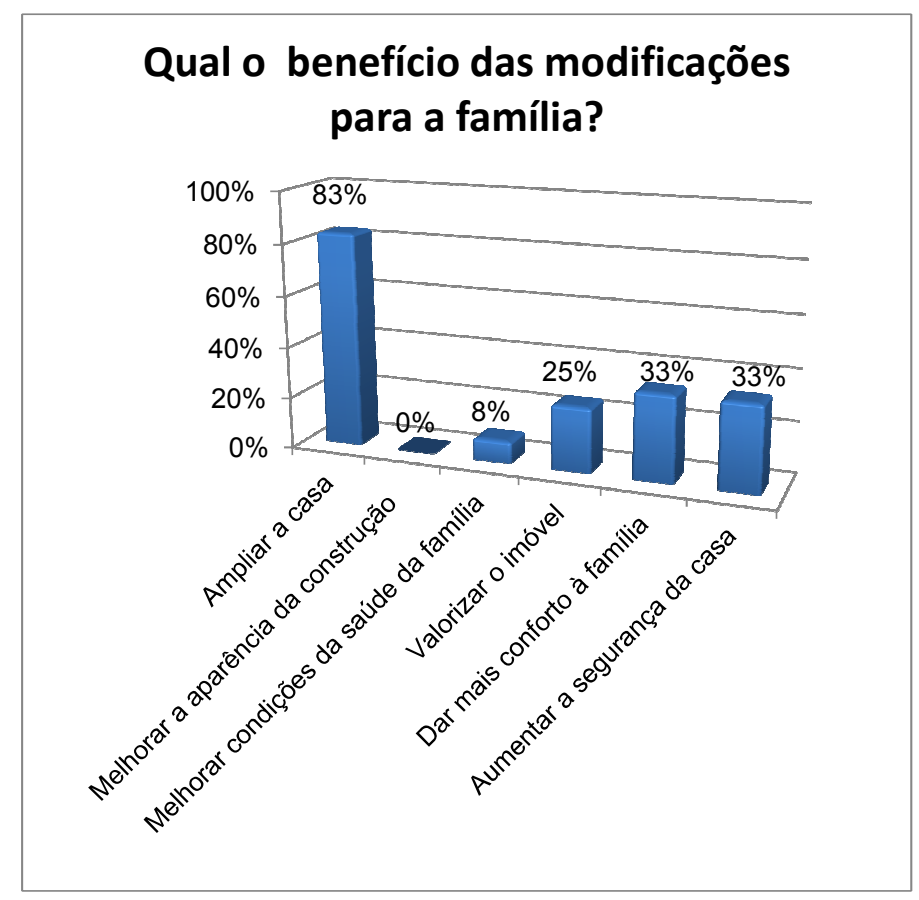

Gráfico 17 - Estudo de Caso 1: Benefício das modificações

\subsubsection{Apresentação e Análise dos Resultados da Avaliação Técnica}

Além das entrevistas, foi realizada uma avaliação técnica dos imóveis através de visita aos cômodos das casas, em companhia de um ou mais moradores.

Das famílias que realizaram modificações nas residências, todas construíram muro e portão e algumas delas ainda fizeram alguma outra alteração no quintal. 

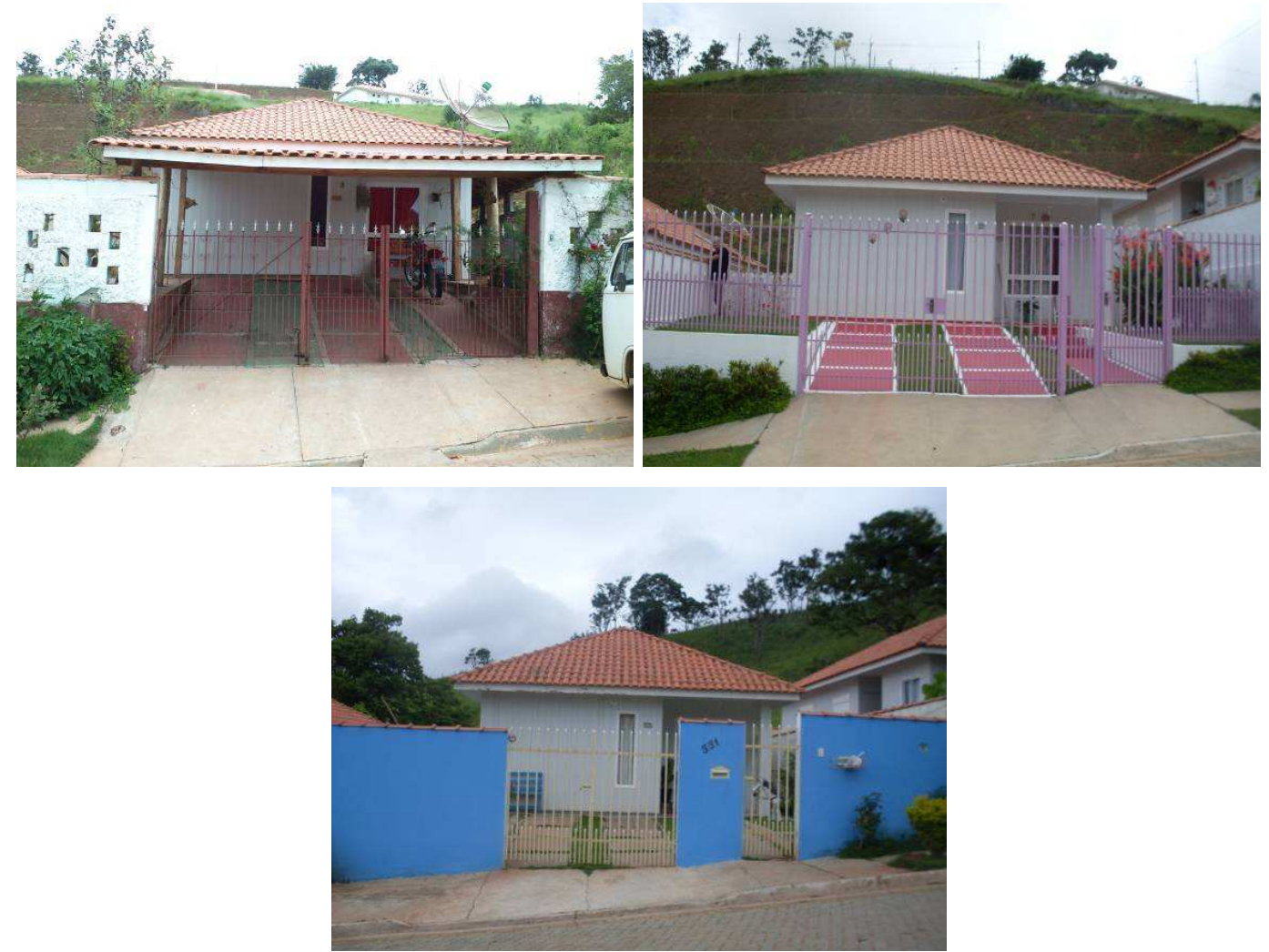

Figura 33 - Exemplos de muros e portões executados pelos moradores Fonte: a autora.

Com relação à avaliação do terrapleno, foram verificadas boas condições em quase todas as unidades, com exceção da SLP02, que apresenta trincas no muro de divisa, possivelmente devidas à acomodação do aterro.

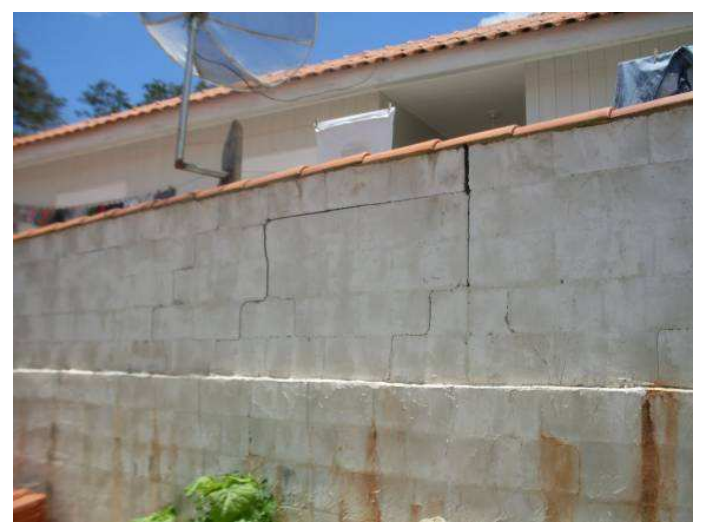

Figura 34 - Trincas no muro de divisa da SLP02 Fonte: a autora. 
Duas moradoras relataram, também, o empoçamento de água no quintal, em trechos que são revestidos por pedrisco nos corredores laterais. Uma moradora relatou que, quando chove, a água chega quase à altura da porta da área de serviço, mas nunca aconteceu de a água invadir o interior da casa.

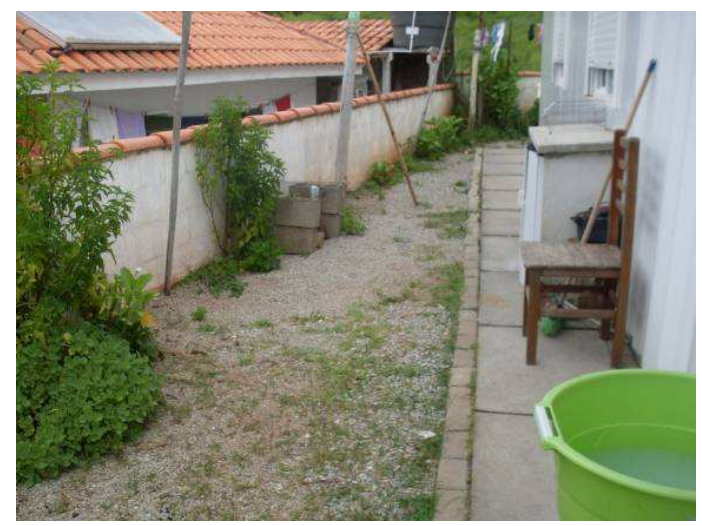

Figura 35 - Trecho do terreno da SLP10 que apresenta empoçamento de água Fonte: a autora.

Com relação às modificações no quintal, notou-se que a maioria dos moradores optou por executar um piso cimentado em algumas partes, deixando alguns trechos gramados ou ajardinados, inclusive com pequenas hortas.

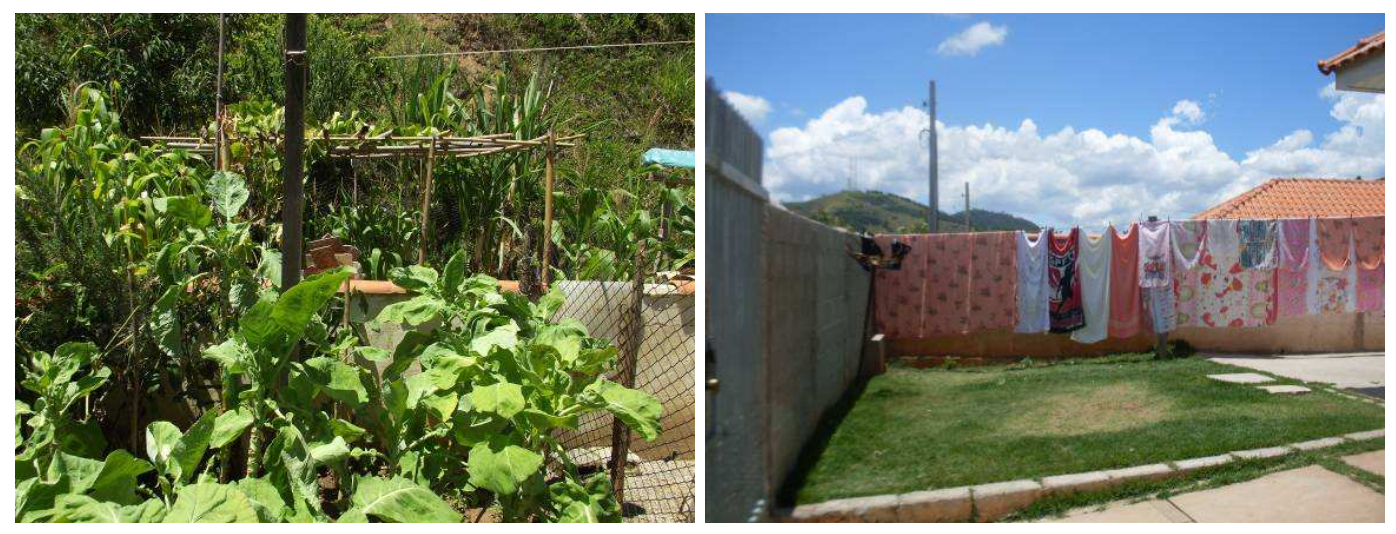

Figura 36 - Horta na SLP01 e gramado na SLP02

Fonte: a autora. 

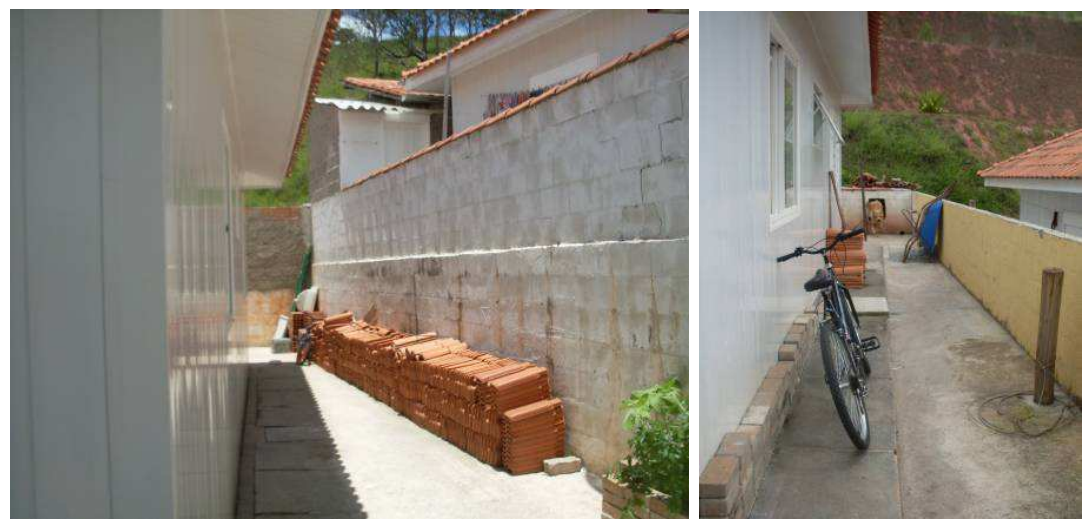

Figura 37 - Trechos cimentados no quintal da SLP02 e da SLP08 Fonte: a autora.

Duas famílias colocaram outros tipos de piso na área externa, mas apenas em partes do lote. Na casa SLP08 foi aplicado piso de rochas ornamentais em um trecho da frente do lote e na SLP12 foi utilizado piso cerâmico nos corredores e fundos, conforme ilustra a figura 38 .
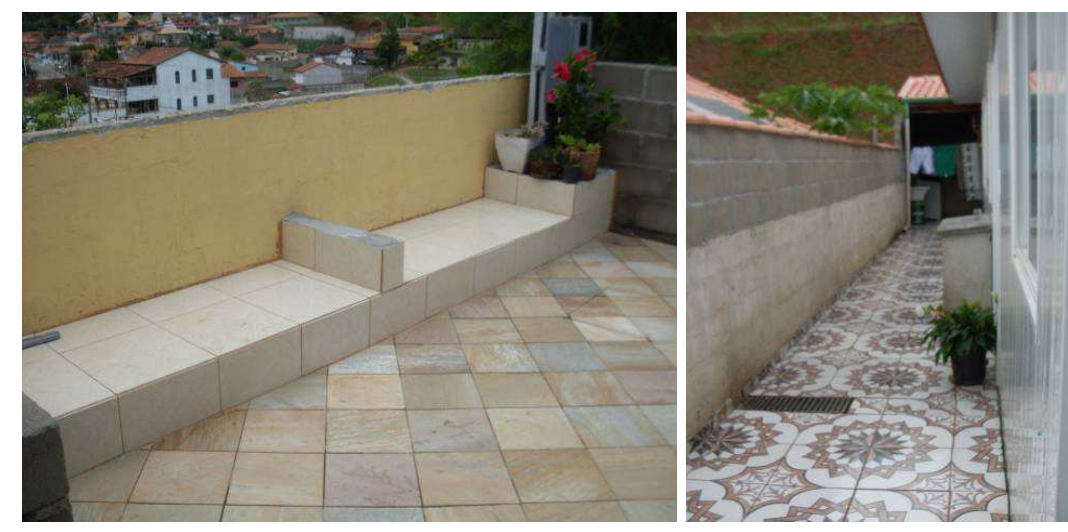

Figura 38 - Pisos aplicados nos quintais das casas SLP08 e SLP12 Fonte: a autora.

As fundações tipo radier encontram-se parcial ou totalmente inacessíveis, entretanto, não há sinais de patologias relacionadas a essas estruturas. Nos cômodos novos, segundo relatos dos moradores, foram executadas fundações tipo estacas moldadas in loco. Esses elementos também se encontram inacessíveis e não foi possível confirmar essa informação, mas não foram verificados problemas ligados a essas estruturas.

A estrutura e a vedação das unidades são compostas de paredes de perfis de PVC preenchidos com concreto e laje pré-fabricada, como já foi apresentado no item 
6.1.2, e apresentam boas condições. No entanto, quatro moradores relataram a presença de umidade nesses elementos, sendo que alguns deles, todos da rua três, relataram que no inverno a umidade é tanta que a água chega a escorrer pelas paredes dos quartos. Em 7 das 12 casas visitadas os moradores relataram a presença de umidade no teto do banheiro, independentemente da localização dessas casas. A moradora da casa SLP06 relatou que passou um produto químico no teto e paredes dos dormitórios e banheiro para reduzir o cheiro de umidade e não criar mofo nessas regiões, entretanto, a moradora não soube informar que tipo de produto era esse.

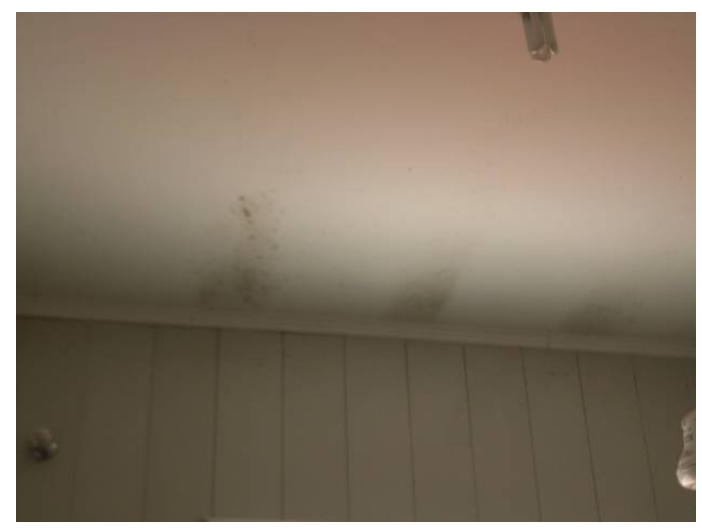

Figura 39 - Sinais de umidade no teto do banheiro da casa SLP02 Fonte: a autora.

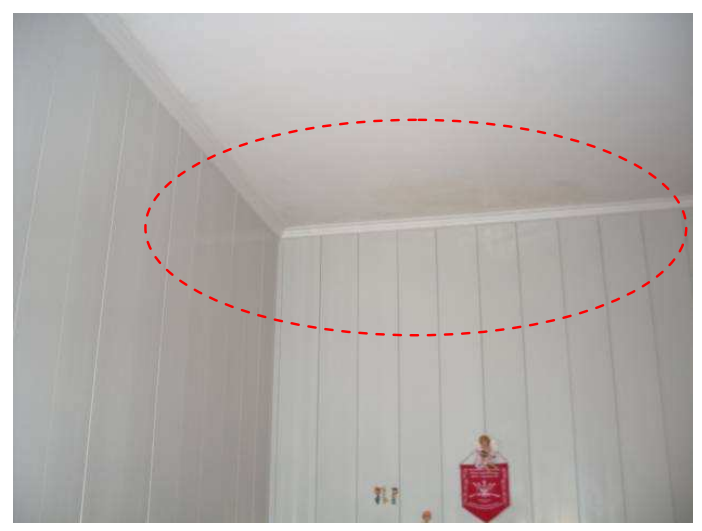

Figura 40 - Sinais de infiltração no teto e paredes do dormitório 1 da SLP06 Fonte: a autora.

Verificou-se, também, que 4 famílias executaram cômodos novos dentro do lote, o que corresponde a $40 \%$ das casas que sofreram alguma modificação. 
Para a construção desses cômodos não pôde ser utilizado o mesmo sistema construtivo e os moradores optaram pela execução de alvenarias com blocos de concreto, com tijolos cerâmicos e tijolinhos maciços de barro, sendo que em alguns casos esses tipos de materiais foram misturados em uma mesma parede. Em todos os casos de construção de novos cômodos, esses ambientes não contam com laje de cobertura e não há ligação direta com a estrutura da casa original, de forma que esta não foi comprometida. Além disso, todos os cômodos possuem entradas independentes, de forma que não foi necessário realizar aberturas nas paredes de Concreto PVC para a instalação de portas. No geral, não foram observadas patologias nessas novas estruturas e vedações.

Em dois desses casos, o cômodo novo foi destinado a receber um novo dormitório nos fundos do lote, sendo que em um deles foi executado também um banheiro, como mostra a figura 41.

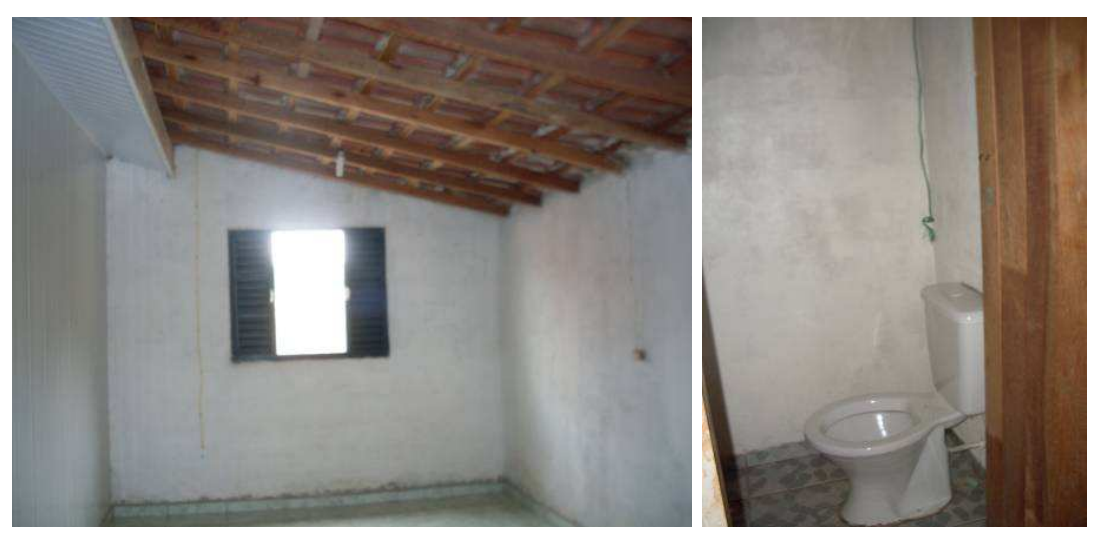

Figura 41 - Cômodo e banheiro novos executados na SLP04.

Fonte: a autora.

No terceiro caso, foi construída uma cozinha na frente do lote, o que provocou uma redução significativa da iluminação e deixou a cozinha nova muito escura e pouco ventilada (figura 42). 

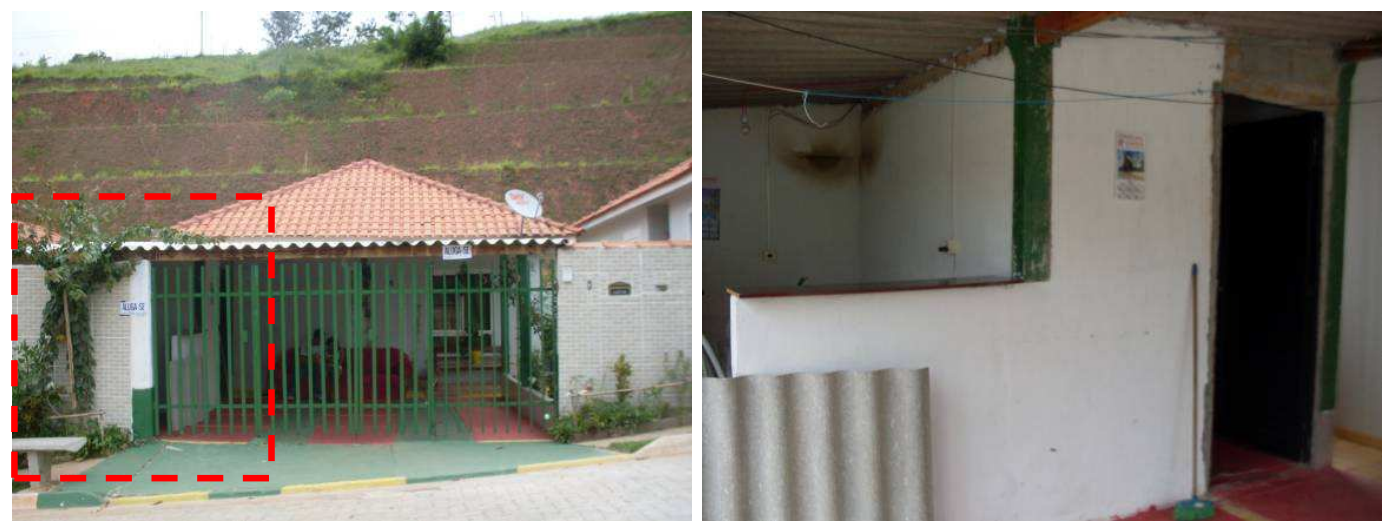

Figura 42 - Cozinha nova construída na frente do lote da SLP07 Fonte: a autora.

Já no quarto caso, foi construída uma segunda casa nos fundos do lote, composta por uma cozinha, um quarto e um banheiro onde habita uma segunda família com parentesco de $1^{\circ} \mathrm{grau}$ com os moradores que receberam a casa original.

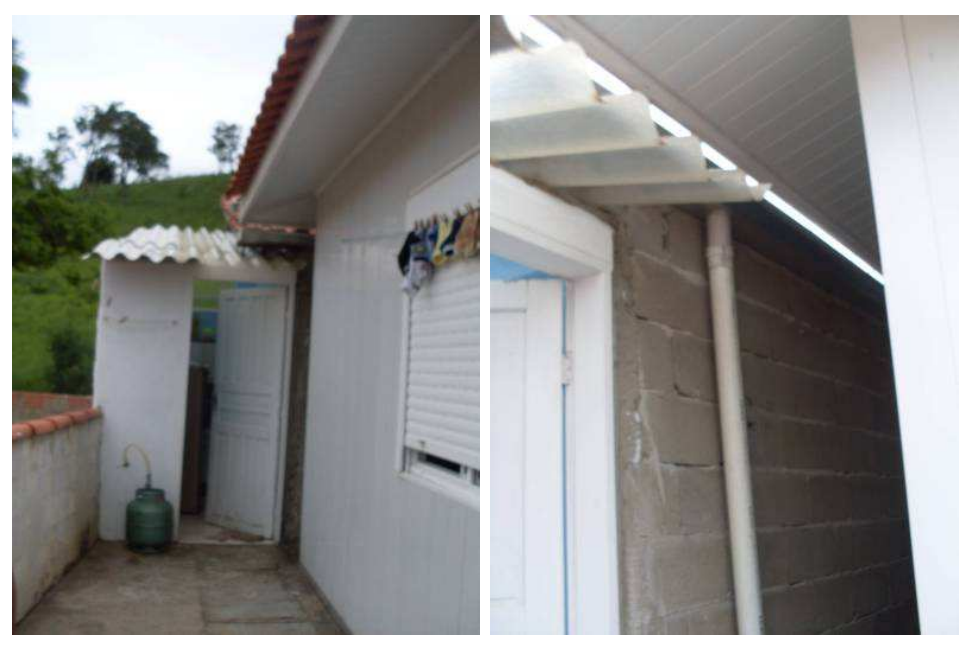

Figura 43 - Detalhe da nova residência executada no lote da casa SLP11 Fonte: a autora.

Embora nenhum morador tenha admitido, mostrou-se muito provável a hipótese de esses dormitórios novos terem sido construídos para, além de aumentar a casa e o conforto da família, fornecer uma renda extra no Carnaval. Durante essa época, a cidade recebe muitos turistas e a rede hoteleira não suporta a demanda, tornando comum a prática de alugar as próprias casas ou cômodos delas para os turistas, o que gera uma renda extra à família em um período muito curto de tempo. Essa hipótese se apoia, principalmente, no fato de na última visita ao 
empreendimento, realizada no início de janeiro de 2013, terem sido observadas placas de aluguel para o Carnaval em algumas das casas.

A execução de nova área de serviço também foi uma modificação bastante realizada neste conjunto habitacional, uma vez que muitas famílias optaram por utilizar o espaço originalmente destinado à área de serviço para ampliar o espaço destinado às atividades da cozinha, como os moradores da casa SLP12, mostrada na figura 45. Neste caso, muitas famílias optaram por instalar uma porta sanfonada branca para fechar o espaço da área de serviço, que era aberto para o corredor lateral, no entanto, o tamanho padrão dessas portas não permite vedar toda a altura do vão. Assim, algumas famílias optaram por deixar um vão aberto na parte superior dessa porta e apenas uma das famílias executou a vedação desse vão com perfis de forro de PVC (figura 46).

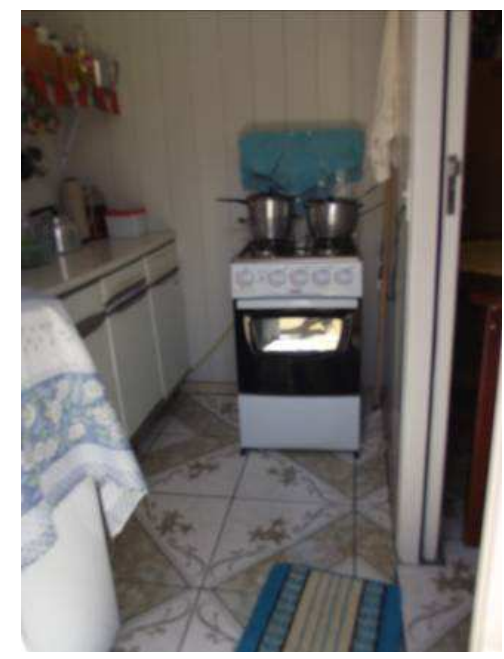

Figura 44 - Extensão da cozinha na SLP01

Fonte: a autora.
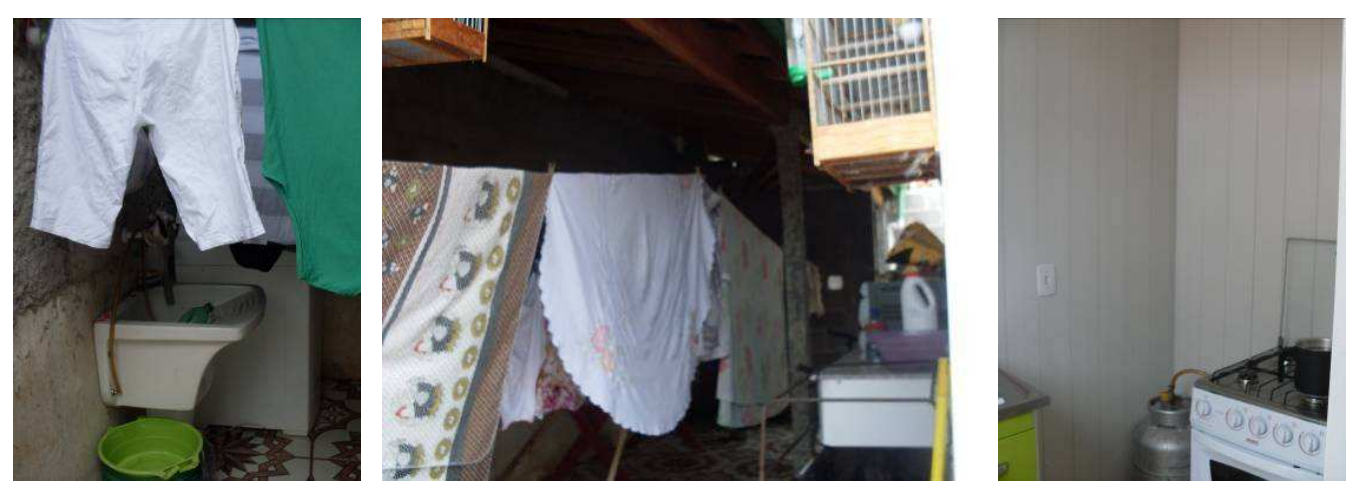

Figura 45 - Nova área de serviço e extensão da cozinha na SLP12

Fonte: a autora. 

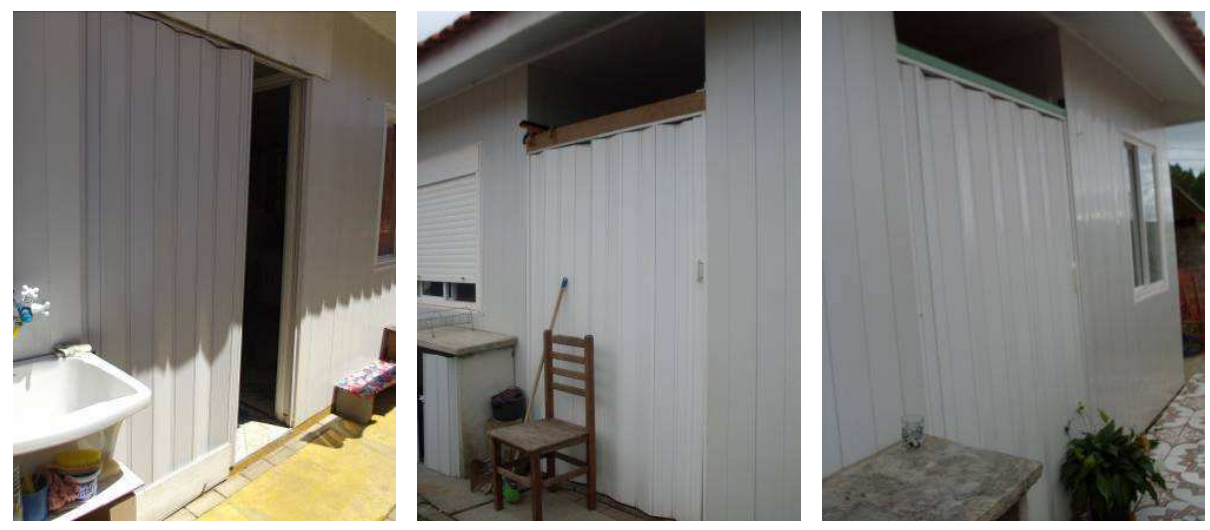

Figura 46 - Fechamento da área de serviço nas casas SLP01, SLP10 e SLP12 Fonte: a autora.

A escolha dessas portas deve-se ao desejo dos moradores de manter o mesmo padrão estético da casa original, que já conta com janelas e portas de PVC.

A avaliação técnica realizada nessas unidades habitacionais revelou a ocorrência de alguns problemas nessas esquadrias. Em algumas casas as persianas dos dormitórios tiveram seu sistema de abertura e fechamento danificado, provavelmente por mau uso por parte dos moradores, que não estavam acostumados a ele. Apenas em uma casa foi observada a quebra das molduras das janelas, que a moradora atribuiu ao fato de as cortinas serem penduradas diretamente nessas molduras, uma vez que ela e o marido não conseguiram instalar os varões para sustentação dessas cortinas.
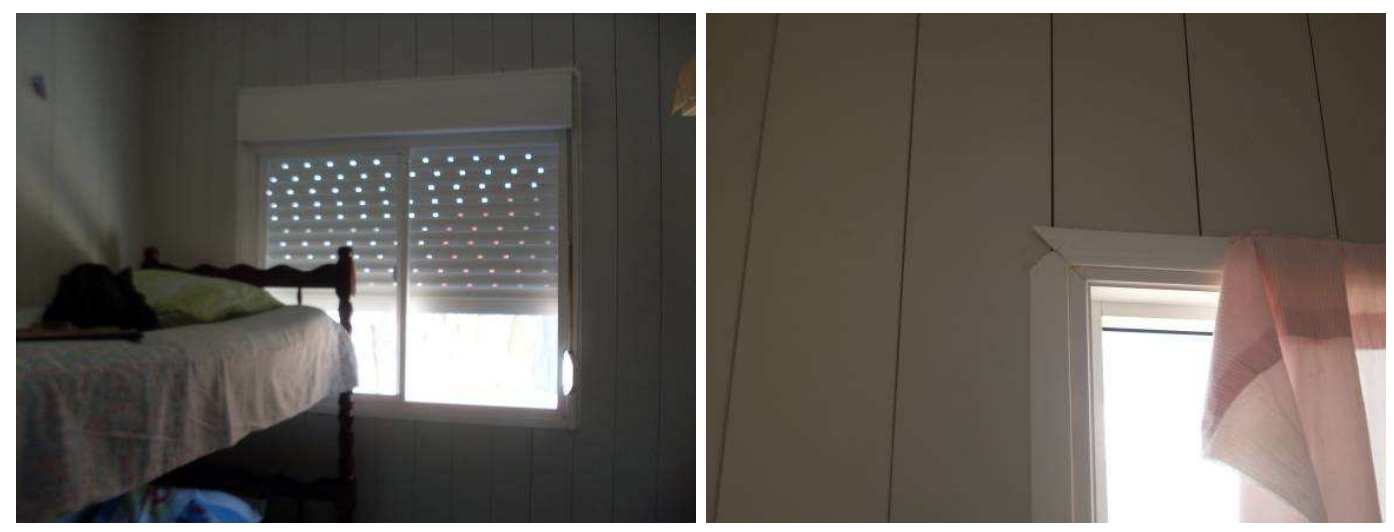

Figura 47 - Sistema de persiana e moldura de PVC danificados na SLP02 Fonte: a autora.

Com relação às coberturas, originalmente executadas com estrutura de madeira e telhas cerâmicas, não foram observadas anomalias. O gráfico 9 indica 
que $60 \%$ dessas famílias realizaram modificações na cobertura, entretanto, é necessário esclarecer que nenhuma residência teve a sua cobertura original alterada ou reformada, sendo que todas as modificações indicadas como cobertura referemse à execução de novas coberturas, seja na garagem ou no fundo do lote para execução de nova área de serviço. Esses novos trechos de cobertura foram executados também com estruturas de madeira e observou-se a utilização de telhas cerâmicas, telhas de fibrocimento e telhas translúcidas de acrílico.

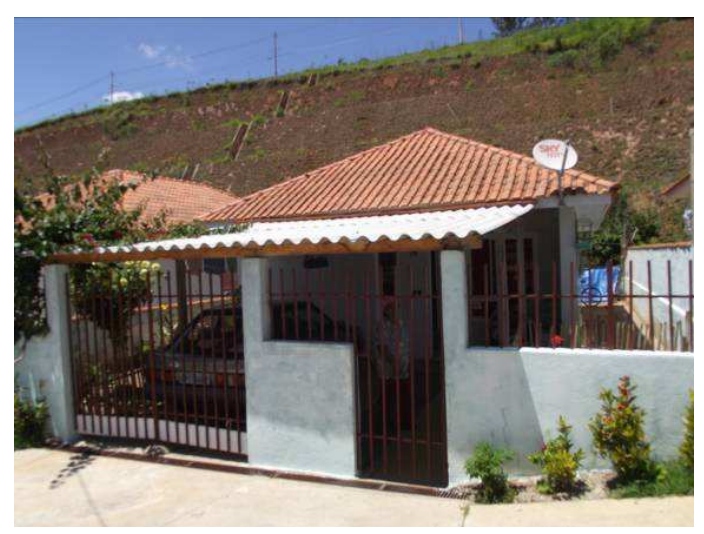

Figura 48 - Vista da cobertura da garagem da SLP01

Fonte: a autora.

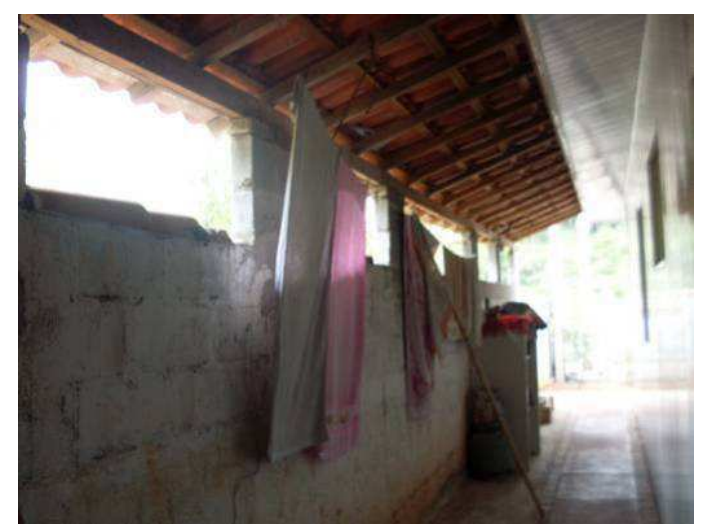

Figura 49 - Cobertura no corredor lateral da SLP04 Fonte: a autora

Com relação ao paramento, ou revestimento, das paredes, os próprios perfis de PVC cumprem esse papel e não foram observadas patologias além da umidade já relatada. Já nos cômodos novos, foram executados reboco e pintura. A nova casa construída no lote da SLP10 não tem qualquer tipo de revestimento externo, como é possível verificar na figura 43. Na casa SLP01, os moradores colaram adesivos em 
todas as paredes alegando que as paredes todas brancas lembram o interior de um hospital (figura 50).

Todas as casas foram entregues com piso cerâmico, entretanto, duas famílias trocaram todo o piso da casa por considerá-lo muito difícil de limpar ou por ter um tom muito claro e sem desenhos. Todos os pisos cerâmicos avaliados apresentam boas condições, sejam os originais ou os novos.
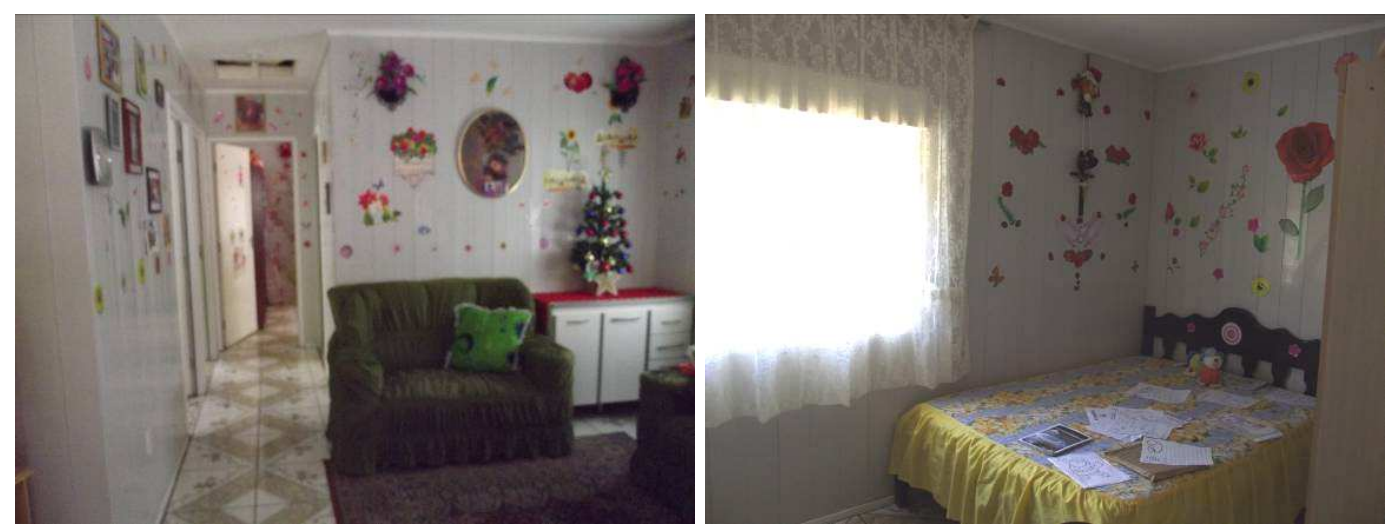

Figura 50 - Adesivos nas paredes e novo piso cerâmico na SLP01 Fonte: a autora.

De modo geral, as instalações elétricas, hidráulicas e de aquecimento solar apresentam boas condições. Apenas na casa SLP03 os moradores relataram que a fiação da campainha apresentou problemas e que houve um vazamento no boiler do sistema de aquecimento, este último já solucionado.

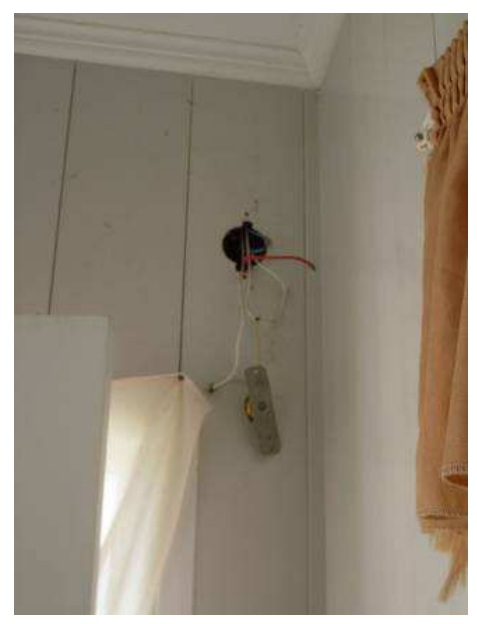

Figura 51 - Fiação da campainha danificada na SLP03 Fonte: a autora. 
Durante as visitas técnicas, foi possível observar que algumas das modificações, em especial a execução de cobertura na garagem e nos corredores, reduziram um pouco a iluminação na sala e dormitórios, mas essa redução não foi significativa. Assim, a grande maioria das casas teve a iluminação e a ventilação classificadas como adequadas, sendo que apenas uma residência teve esses parâmetros classificados como inadequados devido à construção de um cômodo novo.

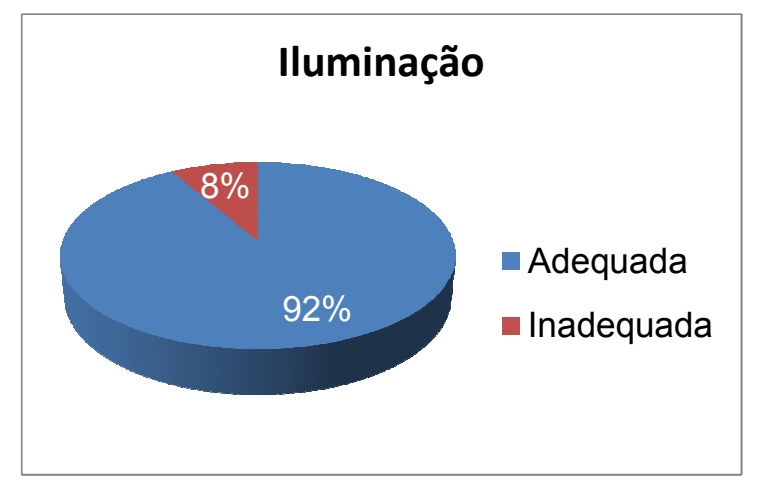

Gráfico 18 - Estudo de Caso 1: Avaliação técnica da iluminação

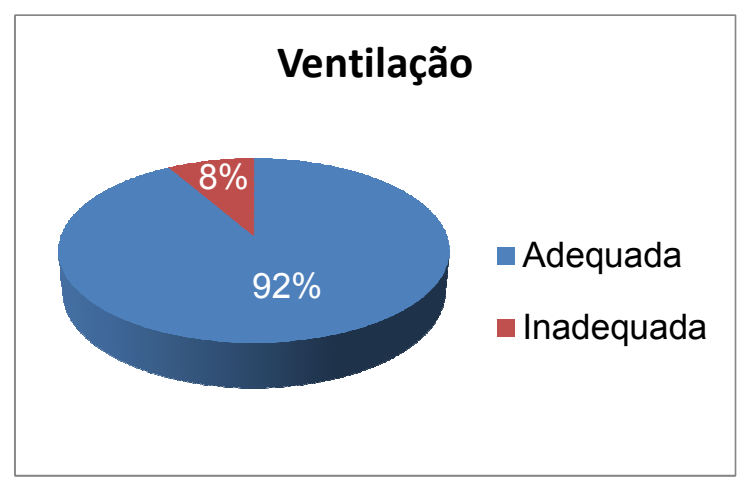

Gráfico 19 - Estudo de Caso 1: Avaliação técnica da ventilação

Na maioria das casas, as modificações foram classificadas como boas, sendo que em uma casa estas foram muito boas e em duas foram razoáveis, conforme mostra o gráfico a seguir:

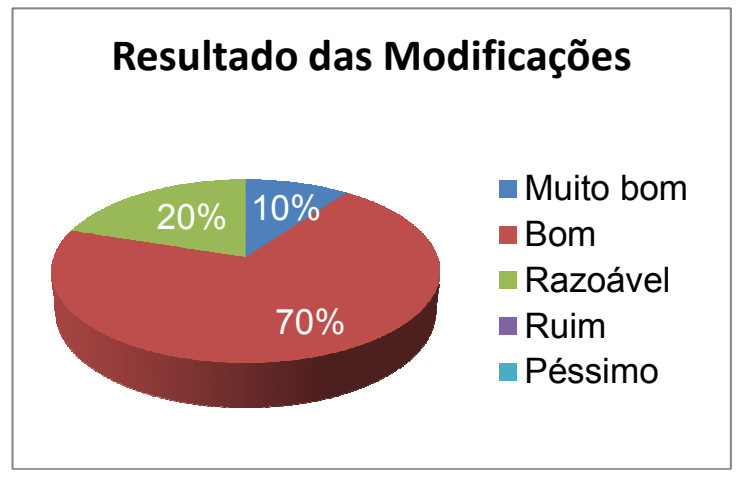

Gráfico 20 - Estudo de Caso 1: Avaliação das modificações realizadas 
O caso mais crítico de modificação realizada foi o da SLP07, conforme ilustra a figura 42, pois a execução de uma nova cozinha na frente do lote promoveu um espaço escuro e com ventilação limitada, além de ser esteticamente desagradável.

Embora não sejam objeto deste estudo, verificou-se, durante as visitas ao empreendimento, que as unidades assobradadas também sofreram modificações e ampliações. Em conversas informais com os moradores, estes relataram muitos problemas nessas unidades, tais como o tamanho reduzido, a falta de privacidade $\mathrm{e}$ o barulho pelo fato de serem geminadas, a distância dos estacionamentos e a dificuldade de acesso e locomoção de alguns moradores em função da escada no interior das unidades. Foram relatados, também, problemas de acomodação do aterro que geraram trincas no piso de algumas unidades. Os moradores reclamaram também da distribuição das unidades, pois, segundo eles, há famílias menores nas casas maiores e vice versa.

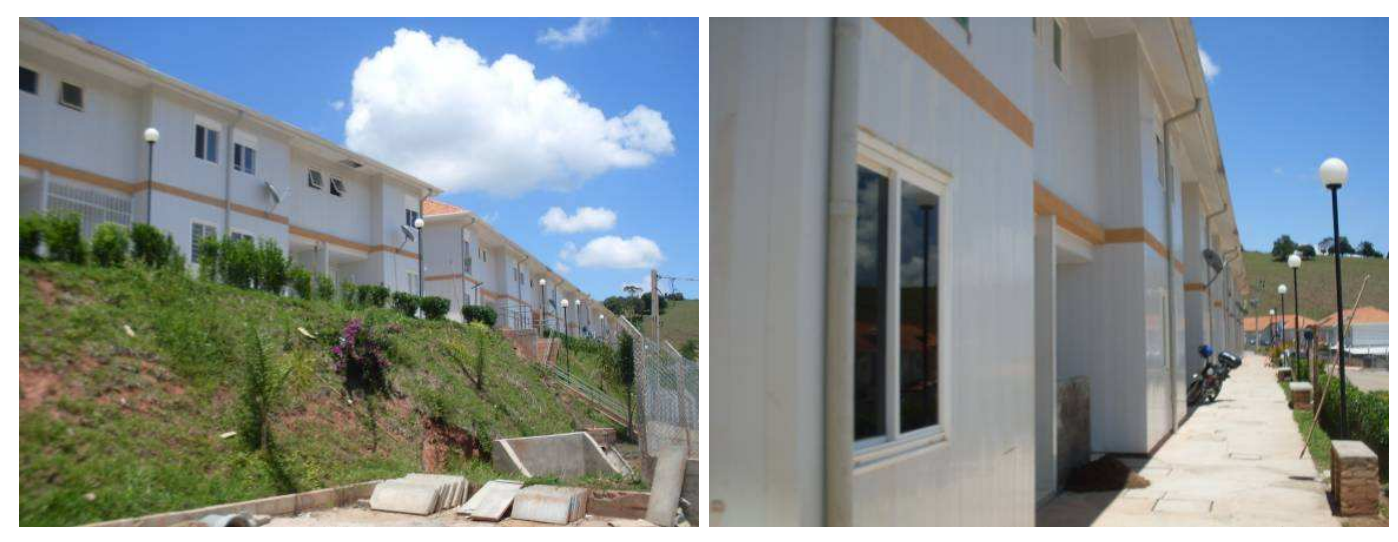

Figura 52 - Vistas gerais das unidades assobradadas Fonte: a autora.
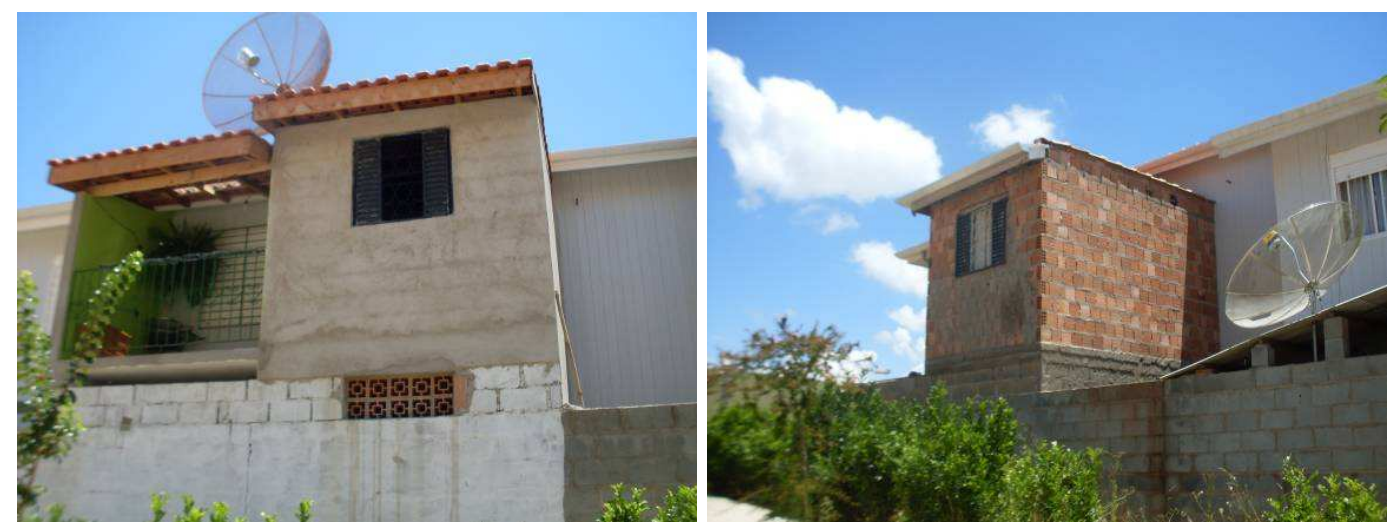

Figura 53 - Detalhe de ampliações realizadas nas unidades assobradadas Fonte: a autora. 


\section{O CASO DE CUNHA}

O empreendimento escolhido para a realização do segundo estudo de caso foi o conjunto habitacional Cunha "B", localizado no Bairro Motor, no município de Cunha. Esse empreendimento é composto por 21 casas geminadas construídas através do sistema de mutirão com o sistema construtivo de paredes de concreto celular moldadas in loco com fôrmas removíveis.

\subsection{O Empreendimento}

\subsubsection{Cenário}

O município de Cunha está localizado em um ponto privilegiado do Vale do Paraíba, entre as serras do Mar, da Bocaina e Quebra-Cangalha, a uma distância de aproximadamente 235 quilômetros da cidade de São Paulo. Faz divisa com os municípios de Guaratinguetá, Lorena, Silveiras, São José do Barreiro, Areias, Ubatuba, São Luiz do Paraitinga e Lagoinha, no Estado de São Paulo, e Paraty no Estado do Rio de Janeiro. Apresenta uma extensão territorial de aproximadamente $1.407 \mathrm{~km}^{2}$ de colinas e montanhas e uma população de 21.804 habitantes em 2012 (FUNDAÇÃO SEADE, 2012; EMPLASAGEO, 2012).

O clima é seco e temperado e a topografia acidentada e montanhosa. Possui hidrografia abundante, formada pelos rios Paraitinga, Paraibuna e Jacuí e por diversos ribeirões, tais como: Peixe, Cedro, Jacuizinho, Jacuí-Mirim, entre outros. A altitude é muito diferente em toda a extensão do município, variando entre 760 metros junto à divisa com o município de Lagoinha e 1840 metros na Pedra da Macela, no alto da Serra do Mar. Cunha se orgulha de ser o município que conserva a maior reserva de Mata Atlântica do país e está dentro de áreas verdes protegidas expressivas, o Parque Estadual da Serra do Mar e Parque Nacional da Serra da Bocaina (EMPLASAGEO, 2012; TONUSSI, 2012). 

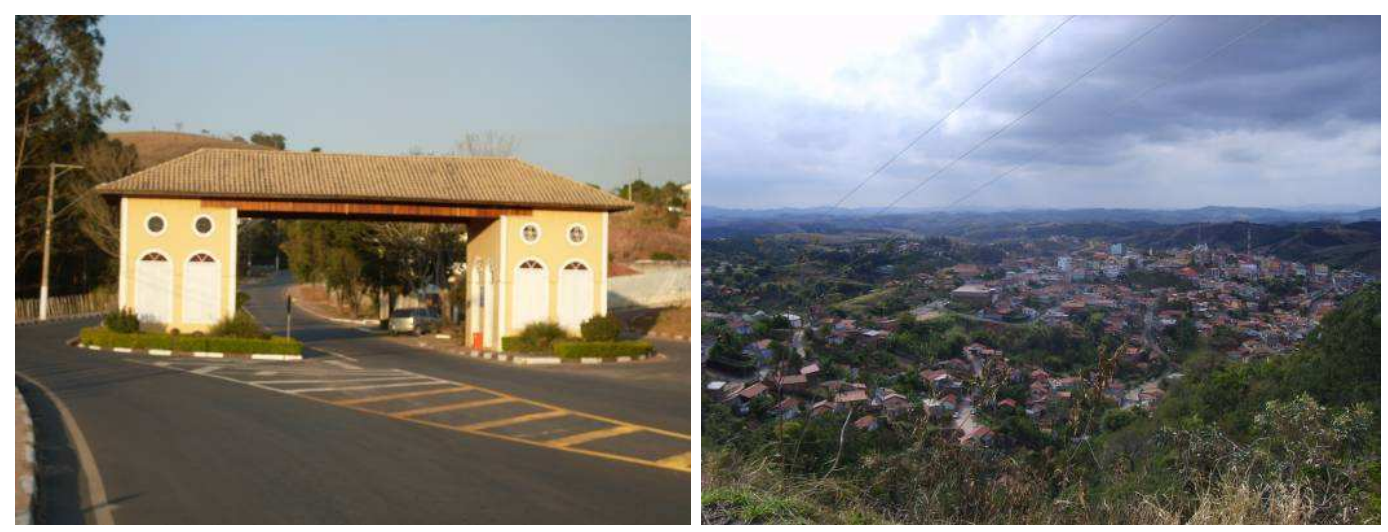

Figura 54 - a) Portal da cidade de Cunha; b) Vista geral da cidade de Cunha. Fonte: a autora.

O povoado teve início por volta de 1695, durante o ciclo do ouro, com a construção de inúmeras fazendas no Caminho do Ouro, estrada que ligava Minas Gerais ao porto de Paraty e ao Rio de Janeiro, para atender as tropas que buscavam ouro em Minas Gerais. Em 1785, o povoado foi elevado à posição de vila por ordem do capitão e general Sr. Francisco da Cunha Menezes e recebeu nome de Nossa Senhora da Conceição de Cunha. Em 1858 foi declarado município e teve sua denominação simplificada para Cunha. Imagina-se que o nome do município seja uma homenagem ao seu fundador e sua família, os Cunha Menezes (EMPLASAGEO, 2012; FUNDAÇÃO SEADE, 2012).

Em 1932 tornou-se palco de batalha durante a Revolução Constitucionalista em combates que duraram três meses e revelaram o lavrador Paulo Virgínio como líder e mártir na ocasião, assassinado por não revelar a localização das tropas paulistas (EMPLASAGEO, 2012). Logo depois, em 1948, o município foi declarado Estação Climática (TONUSSI, 2012).

Sua economia é baseada nas atividades relacionadas aos serviços, comércio, turismo, pecuária leiteira e de corte, bem como no cultivo de milho, feijão, pinhão, trutas, entre outros. Seu Produto Interno Bruto (PIB) foi de R 140,42 milhões em 2010 (EMPLASAGEO, 2012; FUNDAÇÃO SEADE, 2012).

Além dos atrativos turísticos de sua diversidade natural, com dezenas de cachoeiras, nascentes, riachos e uma vegetação abundantemente rica, Cunha é também um importante polo de cerâmica artística na América do Sul, contando com diversos ateliês que contam com uma produção de alta qualidade e variedade (TONUSSI, 2012). 

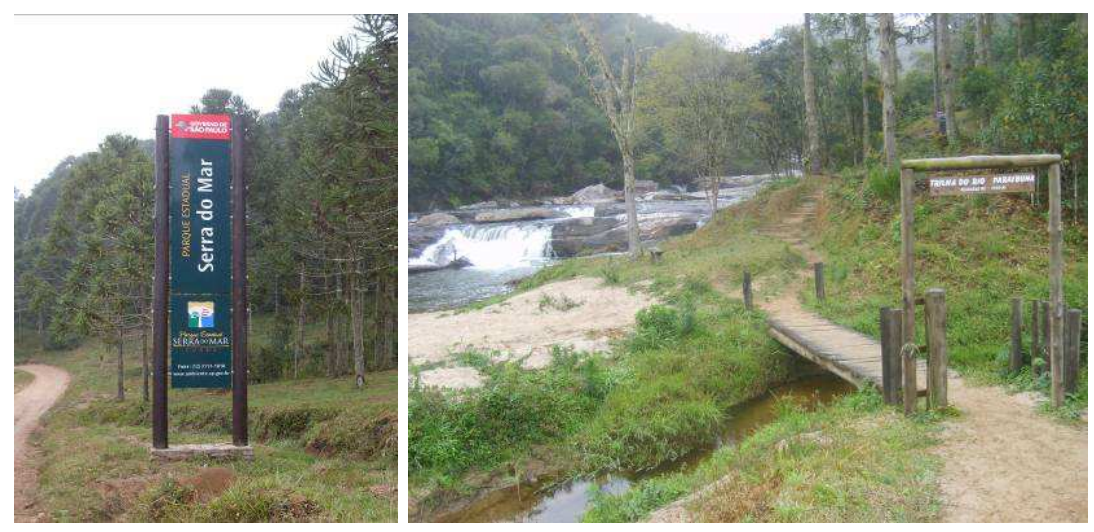

Figura 55 - Parque Estadual da Serra do Mar - Divisão Cunha Fonte: a autora.

Outro atrativo da cidade são as diversas festas religiosas e culturais, como a Festa do Divino, a Festa de Nossa Senhora da Conceição, o Festival de Verão e Fuscunha, o Carnaval de Rua, o Festival de Inverno "Acordes na Serra", o Festival de Cerâmica e o Natal Luz, entre outros (TONUSSI, 2012).

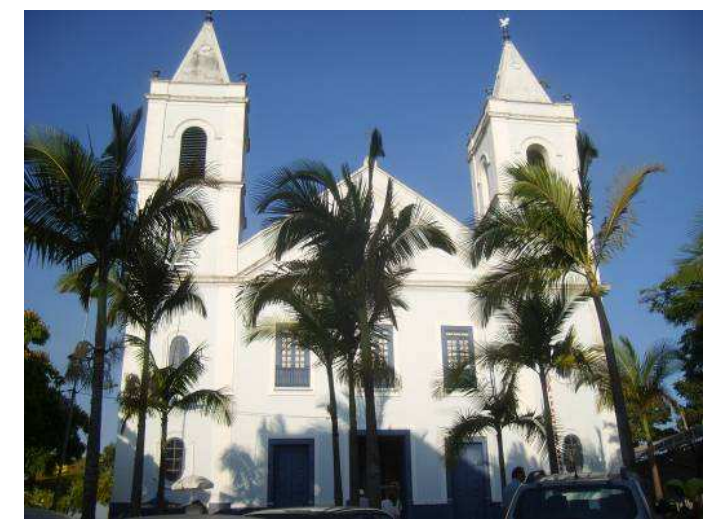

Figura 56 - Igreja Matriz Nossa Senhora da Conceição Fonte: a autora.

Devido à sua topografia acidentada e farta hidrografia, o município apresenta algumas áreas de risco povoadas. Dados da Fundação SEADE indicam que o município contava com 6 áreas de risco ocupadas por moradias em 2003, mas sem a presença de favelas e cortiços. Na tentativa de evitar acidentes e remover as famílias dessas áreas, a CDHU implantou o Conjunto Habitacional Cunha "A", no distrito de Campos de Cunha, em 2002, e o Conjunto Habitacional Cunha "B" em 2005, na região central do município, no Bairro Motor, sendo este último o objeto do segundo estudo de caso apresentado nesse trabalho. 


\subsubsection{Descrição e histórico}

O Conjunto Habitacional Cunha "B" é integrado à malha urbana da cidade, sendo acessado pela Rua Miguel M. da Silva e pela Rua Luiz da Silva, no limite da área urbana ao sul da região central do município, a cerca de 1800 metros do centro da cidade.

A gleba apresenta declividade moderada na região das unidades habitacionais, não ultrapassando os $15 \%$, a não ser no fundo dos lotes ao norte da Rua Um, onde há um grande desnível do aterro em relação aos terrenos vizinhos. $A$ oeste das residências há uma área verde com declividade de até $50 \%$ em alguns trechos. Ao sul, o terreno conta com uma área institucional onde hoje há uma pequena área sendo ocupada por uma quadra coberta. Não há terrenos alagadiços e sujeitos a inundação.

Originalmente, o projeto deste conjunto habitacional previa a construção de 26 casas, no entanto, foram construídas apenas 21 em virtude da nascente de água encontrada no local. A figura 57 apresenta a implantação do conjunto, ainda com as 26 casas, sendo que as cinco casas circuladas em vermelho não chegaram a ser construídas. 


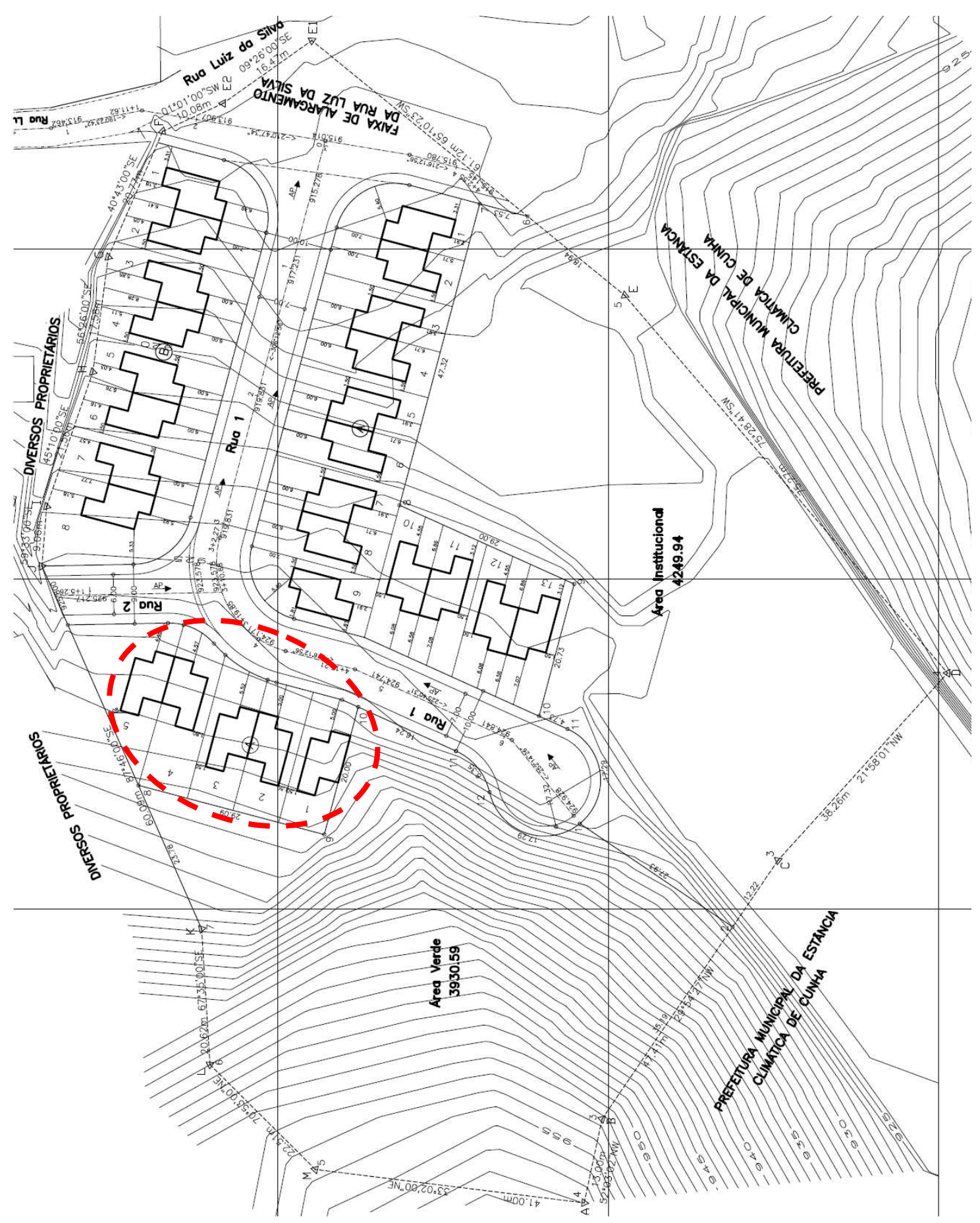

Figura 57 - Implantação do Conjunto Habitacional Cunha "B" Fonte: CDHU, 2010.

As ruas apresentam pavimento asfáltico e as calçadas são cimentadas. $\mathrm{O}$ conjunto habitacional conta, ainda, com iluminação nas vias púbicas através de postes com fiação aérea, rede de abastecimento de água, rede de coleta de esgotos, rede de captação de águas pluviais e serviço de coleta de lixo. 


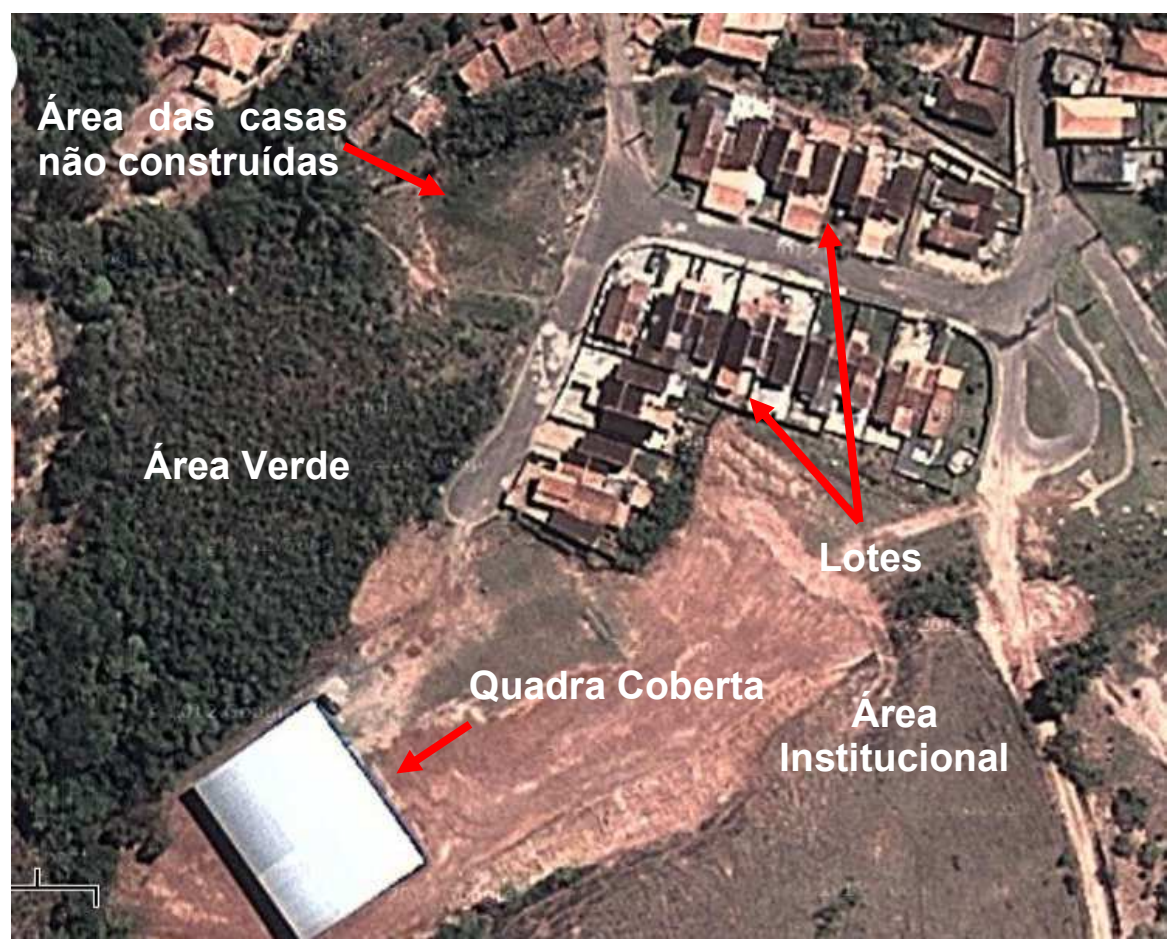

Figura 58 - Vista geral do Conjunto Habitacional Cunha "B" Fonte: GOOGLE MAPS.

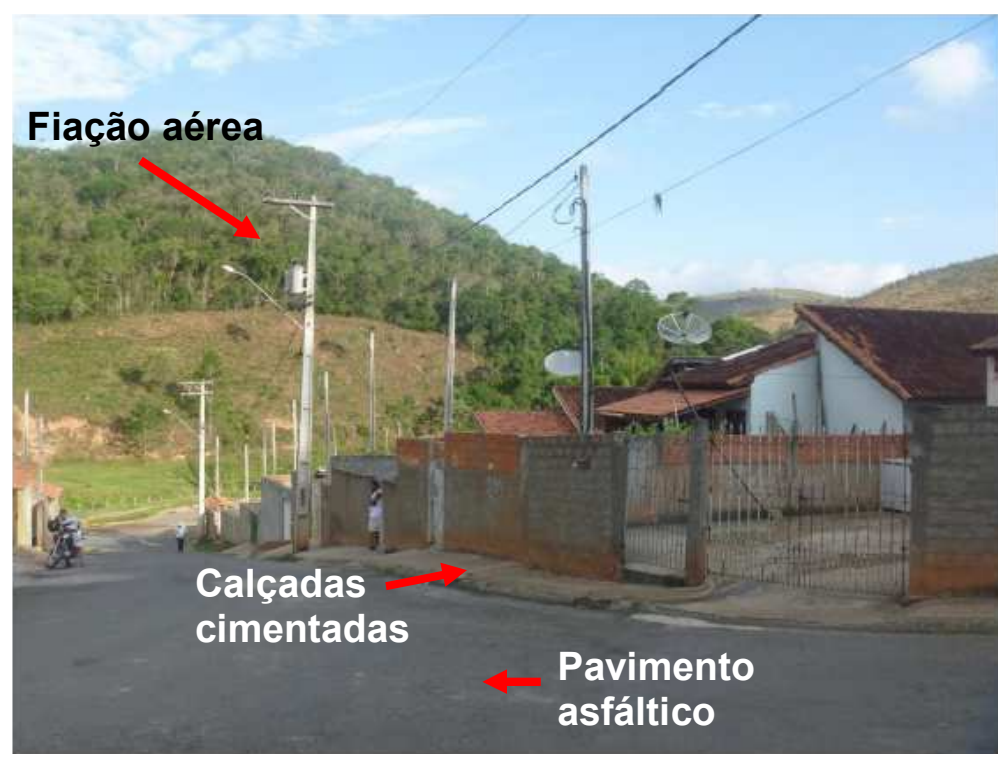

Figura 59 - Vista geral do Conjunto Habitacional Cunha "B" Fonte: EMPLASAGEO, 2012.

As 21 unidades habitacionais são térreas e geminadas duas a duas, seguindo a tipologia TG23A da CDHU. Cada unidade tem $42,71 \mathrm{~m}^{2}$ de área construída, onde foram dispostos sala, cozinha, dois dormitórios e um banheiro, alojados em um lote de aproximadamente $160 \mathrm{~m}^{2}$ (8 m x $20 \mathrm{~m}$ ) de área (SILVA, 2012). 
Antes do início da construção foi realizado o serviço de adequação do projeto padrão da CDHU para o sistema construtivo de paredes de concreto moldadas in loco, onde foi preciso calcular as armaduras e definir o seu posicionamento em projeto. Este serviço foi coordenado pela Associação Brasileira de cimento Portland $(\mathrm{ABCP})$.

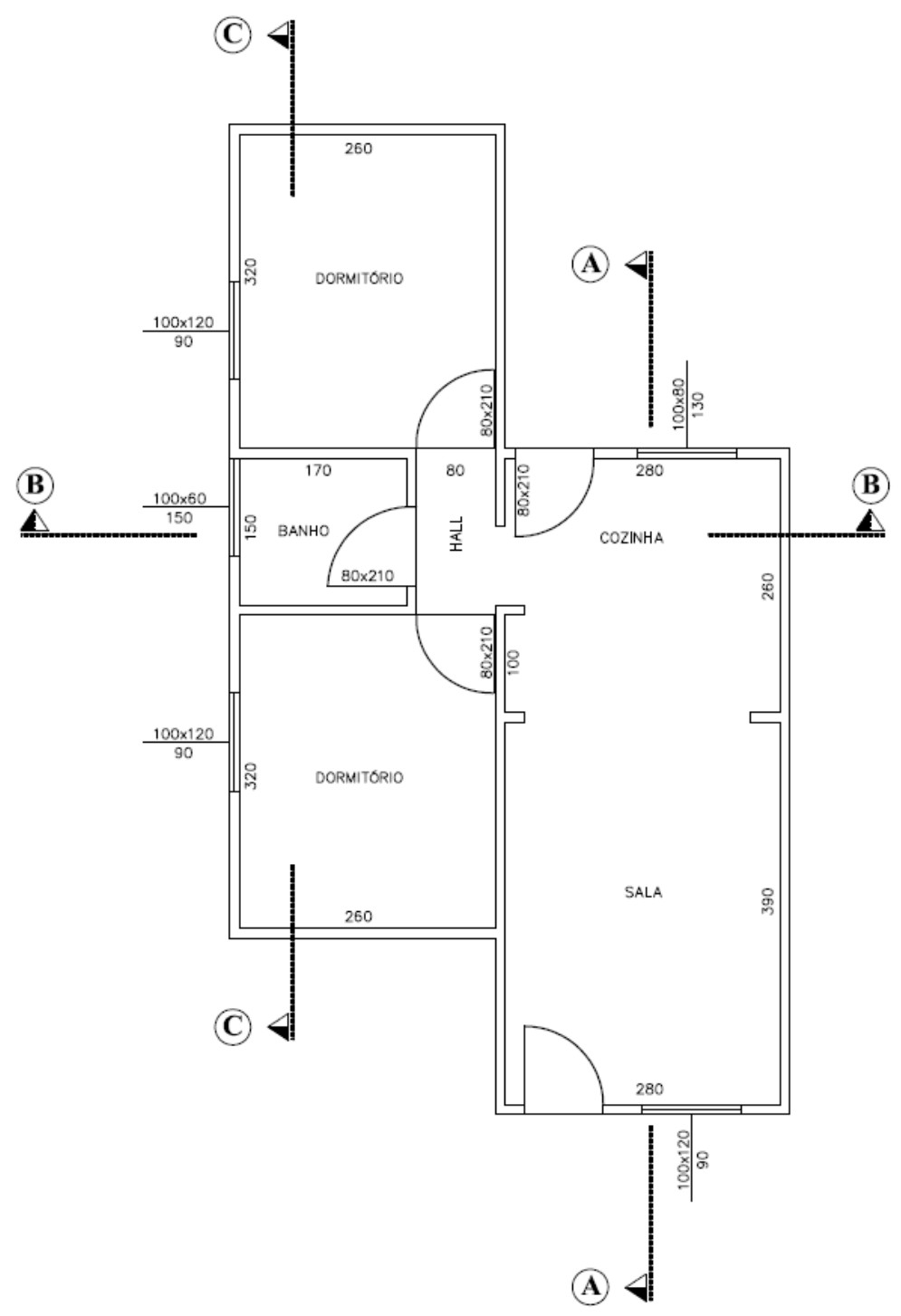

Figura 60 - Tipologia TG23A adaptada ao sistema construtivo Fonte: $\mathrm{CDHU} /$ acervo ABCP. 


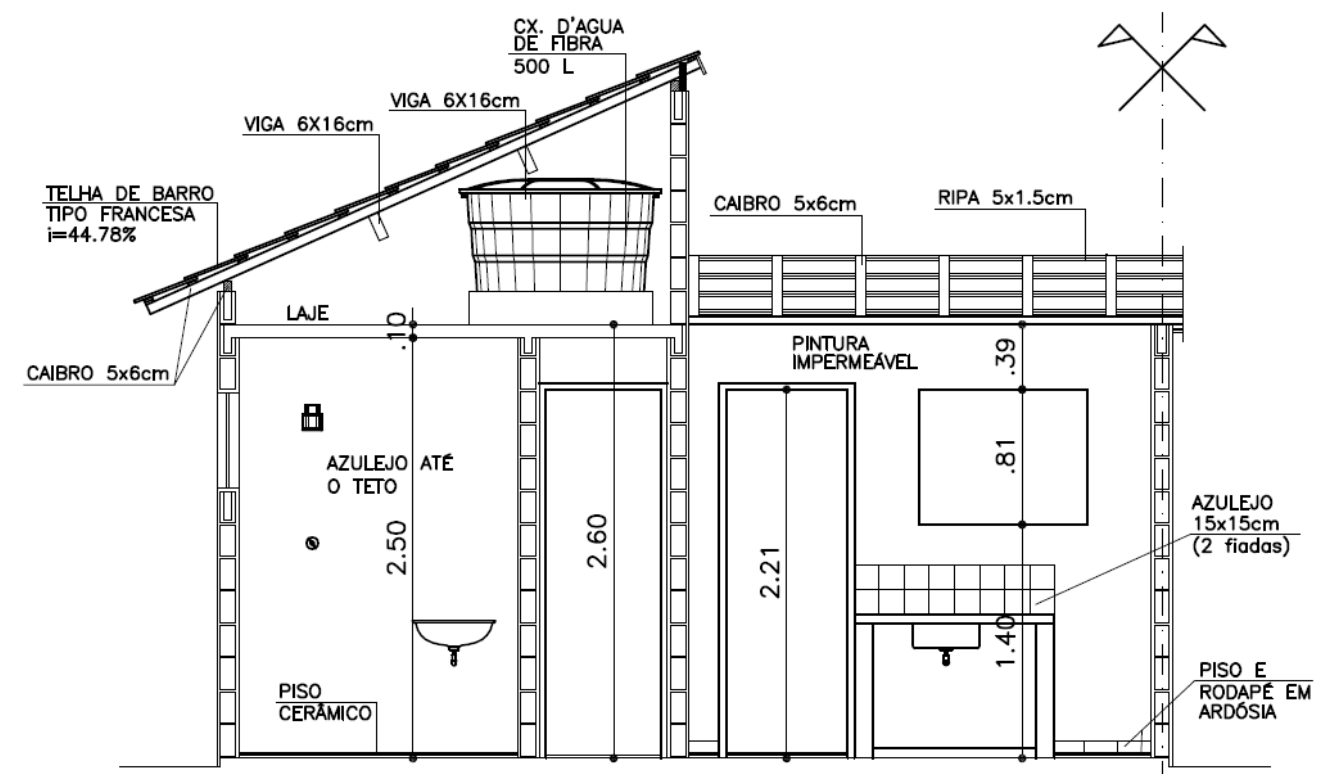

Figura 61 - Corte BB da tipologia TG23A padrão Fonte: CDHU.

As casas foram construídas em regime de mutirão, ou seja, os futuros moradores, chamados de mutirantes, trabalharam na construção das mesmas. Durante 14 meses esses moradores trabalharam de segunda a sexta-feira das $7 \mathrm{~h}$ às 17h na construção de suas casas (SILVA, 2012), sendo obtida uma média de participação de 12 mutirantes durante todo o período de construção.

Segundo o Arq. Carlos Chaves, consultor da ABCP na época e um dos responsáveis por acompanhar a obra, a principal dificuldade encontrada durante a execução foi justamente o uso de mão de obra não treinada e que não tinha o compromisso de comparecer na obra todos os dias (informação pessoal) ${ }^{7}$. Ainda assim, dados colhidos pelos profissionais da $A B C P$ na época relatam uma produtividade de 2 casas por semana ou $7 \mathrm{hh} / \mathrm{m}^{2}$, considerado um resultado melhor do que os obtidos na mesma época em obras da CDHU que adotaram outros sistemas construtivos.

As famílias que tiveram mais horas de trabalho ganharam itens de acabamento a mais do que as demais, como forro e piso, e aquelas que não ajudaram na construção pagam um valor maior pela casa na forma de um acréscimo no valor das parcelas.

\footnotetext{
${ }^{7}$ Informação fornecida pelo Arq $^{\circ}$ Carlos Chaves em entrevista por e-mail em 24/01/2013.
} 


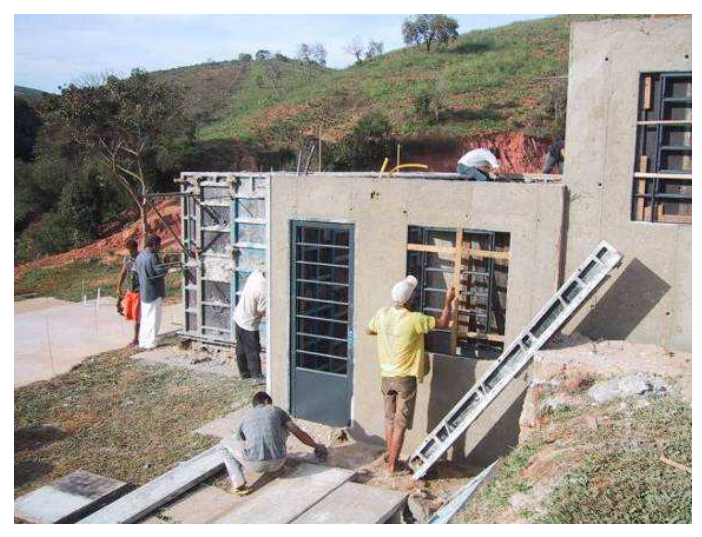

Figura 62 - Fotos da execução das obras em Cunha Fonte: acervo ABCP.

As casas foram construídas sob supervisão de uma empresa gerenciadora, o Consórcio Tecnosolo/ Cobrape, que manteve um mestre de obras e três pedreiros em tempo integral no canteiro para orientar os moradores, além do acompanhamento de um engenheiro. Por ter sido adotado um sistema construtivo inovador para a época, houve um acompanhamento da ABCP também na fase de execução das casas para treinamento das equipes, coordenação da execução das paredes, coordenação dos parceiros e desenvolver a tecnologia do concreto celular.

Estiveram envolvidas na construção, ainda, as empresas Engemix, que forneceu o concreto, a Pashal, fornecedora das fôrmas moduladas, a Forschaum, que alugou o equipamento gerador de espuma e forneceu o espumígeno e a Otto Baumgart, fornecedora do aditivo superfluidificante utilizado no concreto.

Ainda durante a construção, já era possível observar um quadro de fissuração nas paredes logo após a desforma, sendo que com o decorrer do tempo as fissuras aumentaram em abertura e extensão.

Assim, antes mesmo da entrega das casas, foi contratada a empresa de consultoria Pacelli, Ragueb e Associados para fazer uma avaliação dessas fissuras. Profissionais da empresa fizeram uma visita técnica ao local e elaboraram um relatório técnico que destaca o fato de que as paredes ficaram muito tempo expostas às intempéries antes da execução das coberturas. O conteúdo deste relatório está resumido na tabela 3 , a seguir: 
Tabela 3 - Resumo do relatório de análise das anomalias nas casas de Cunha

\begin{tabular}{|c|c|c|}
\hline Anomalia & Causa & Reparo \\
\hline $\begin{array}{l}\text { Fissuras } \\
\text { - no sentido horizontal } \\
\text { só nas regiões que } \\
\text { não foram reforçadas } \\
\text { com armadura e estão } \\
\text { limitadas entre as } \\
\text { armaduras; } \\
\text { - no sentido vertical } \\
\text { nas regiões não } \\
\text { armadas e muito } \\
\text { próximas do limite com } \\
\text { a região armada. }\end{array}$ & $\begin{array}{l}\text { A desforma prematura das paredes } \\
\text { gerou esforços não previstos nas peças } \\
\text { com idade de } 12 \mathrm{~h} \text { e permitiu a perda da } \\
\text { água do concreto celular, propiciando as } \\
\text { retrações iniciais. } \\
\text { As regiões reforçadas sofreram menor } \\
\text { influência dos esforços provocados pela } \\
\text { desforma. } \\
\text { A restrição à retração produzida pelas } \\
\text { armaduras nas regiões reforçadas } \\
\text { provavelmente ocasionou as fissuras } \\
\text { (principalmente verticais) nas regiões } \\
\text { não reforçadas. } \\
\text { As telas metálicas de reforço evitaram a } \\
\text { fissuração nas regiões em que foram } \\
\text { inseridas. } \\
\text { As fissuras de retração nas regiões não } \\
\text { armadas foram interrompidas, não } \\
\text { adentrando nas regiões reforçadas. } \\
\text { O fato de as paredes ficarem expostas } \\
\text { às intempéries sem proteção } \\
\text { (molhagem/ secagem) causou o } \\
\text { aumento das fissuras ao longo do } \\
\text { tempo. }\end{array}$ & $\begin{array}{l}\text { A retração inicial que provocou a } \\
\text { fissuração já não mais atua, e } \\
\text { essas fissuras poderiam ser } \\
\text { consideradas passivas, porém, } \\
\text { as movimentações provocadas } \\
\text { pela falta de proteção das } \\
\text { paredes (molhagem e secagem) } \\
\text { tornam estas fissuras ativas. } \\
\text { Assim, os reparos devem ser } \\
\text { executados após a cobertura das } \\
\text { edificações e logo após a sua } \\
\text { execução e cura, as paredes } \\
\text { devem ser protegidas por } \\
\text { revestimento. } \\
\text { As fissuras devem ser reparadas } \\
\text { com um revestimento } \\
\text { impermeabilizante } \\
\text { monocomponente à base de } \\
\text { cimento, areia selecionada e } \\
\text { resina acrílica e considerado } \\
\text { semi-flexível. No caso das trincas } \\
\text { externas, devem-se aplicar duas } \\
\text { camadas do material, } \\
\text { intercaladas com uma tela têxtil } \\
\text { com largura de } 20 \text { cm. }\end{array}$ \\
\hline $\begin{array}{l}\text { Trincas verticais sobre } \\
\text { as aberturas }\end{array}$ & $\begin{array}{l}\text { Não foram colocadas as telas metálicas } \\
\text { de acordo com o projeto em alguns } \\
\text { pontos localizados, caracterizando } \\
\text { deficiência de execução. } \\
\text { Em uma unidade foi executado um } \\
\text { reparo por grampeamento, o que não } \\
\text { corrigiu esta deficiência. }\end{array}$ & $\begin{array}{l}\text { Refazer localizadamente esses } \\
\text { pontos posicionando a armadura } \\
\text { da forma especificada no projeto, } \\
\text { tomando todos os cuidados com } \\
\text { escoramento das vigas de } \\
\text { madeira e do telhado bem como } \\
\text { das paredes. }\end{array}$ \\
\hline $\begin{array}{l}\text { Deficiências na } \\
\text { superfície das paredes } \\
\text { (pequenos buracos) }\end{array}$ & $\begin{array}{l}\text { Existência de ar aprisionado entre a } \\
\text { forma e a superfície do concreto, } \\
\text { causado por adensamento inadequado } \\
\text { do concreto celular. }\end{array}$ & - \\
\hline $\begin{array}{l}\text { Armaduras expostas } \\
\text { com início de corrosão } \\
\text { por oxidação }\end{array}$ & $\begin{array}{l}\text { Cobrimento insuficiente por deficiência } \\
\text { ou falta de espaçadores }\end{array}$ & $\begin{array}{l}\text { Preenchimento com argamassa } \\
\text { cimentícia aditivada com resina } \\
\text { acrílica específica para execução } \\
\text { de reparos rasos, com } \\
\text { cobrimento mínimo de } 1 \mathrm{~cm} \\
\text { sobre a armadura. }\end{array}$ \\
\hline
\end{tabular}

Fonte: acervo ABCP. 
Segundo o Arq. Carlos Chaves $^{8}$, muitos dos problemas observados nas casas podem estar ligados a falhas executivas de posicionamento das armaduras e não utilização de espaçadores. O profissional garante que ele mesmo presenciou um caso em que "o mutirante não colocou aço em uma verga de porta por conta própria". Chaves afirma, ainda, que todos os reparos sugeridos pela consultoria foram realizados antes da entrega das casas, em parceria com a empresa Vedacit.

As 21 unidades habitacionais do Conjunto Habitacional Cunha "B" foram entregues em 2005 sem o acabamento, como mostra a tabela a seguir, que apresenta uma descrição das casas entregues baseada nos 10 órgãos básicos do edifício apresentados por Roméro e Ornstein (2003):

Tabela 4 - Descrição das unidades habitacionais do Conjunto Cunha "B"

\begin{tabular}{|c|c|}
\hline $\begin{array}{l}\text { Órgão do } \\
\text { Edifício }\end{array}$ & Descrição \\
\hline Terrapleno & $\begin{array}{l}\text { Os lotes foram entregues sem muros, com exceção das divisas de lotes } \\
\text { que tinham um desnível no terreno, onde foram feitos pequenos muros } \\
\text { de contenção apenas até o nível do lote mais alto. Os lotes foram } \\
\text { entregues com grama e um caminho formado de placas de concreto do } \\
\text { limite frontal até a entrada das unidades habitacionais. }\end{array}$ \\
\hline Fundação & A fundação adotada é do tipo radier. \\
\hline Estrutura & $\begin{array}{l}\text { Paredes de concreto celular moldadas in loco, com concreto de } \\
\text { densidade } 1.500 \mathrm{kgf} / \mathrm{m}^{3} \text { e resistência média } \mathrm{f}_{\mathrm{ck}} 5 \mathrm{MPa} \text {. Laje maciça de } \\
\text { concreto apenas no banheiro e no corredor. }\end{array}$ \\
\hline Cobertura & Estrutura de madeira e telhas cerâmicas tipo romana. \\
\hline Vedações & $\begin{array}{l}\text { A vedação é realizada pelas próprias paredes de concreto celular } \\
\text { moldadas in loco. Os oitões são de alvenaria de blocos de concreto. }\end{array}$ \\
\hline Esquadrias & Portas e janelas de aço com pintura em esmalte e vidros. \\
\hline Paramentos & $\begin{array}{l}\text { Pintura externa com textura acrílica hidrorrepelente e interna com látex } \\
\text { PVA sobre massa corrida. Os oitões são revestidos com argamassa. }\end{array}$ \\
\hline Pisos & As casas foram entregues apenas com o piso cimentado. \\
\hline Instalações & $\begin{array}{l}\text { Instalação elétrica e hidráulica convencional, com eletrodutos plásticos, } \\
\text { tubulação de PVC e fiação de cobre encapada. Todas as instalações } \\
\text { foram embutidas nas paredes. }\end{array}$ \\
\hline
\end{tabular}

\footnotetext{
${ }^{8}$ Informação fornecida pelo $\mathrm{Arq}^{\circ}$ Carlos Chaves em entrevista por e-mail em 24/01/2013.
} 


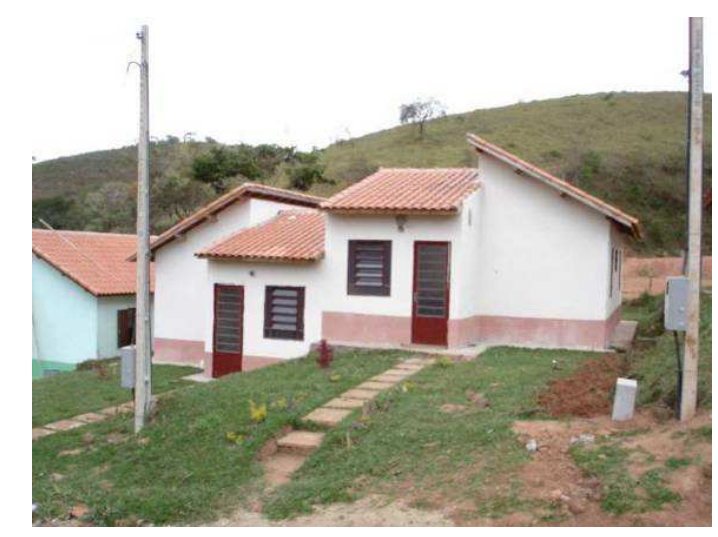

Figura 63 - Casa entregue em Cunha Fonte: acervo $\mathrm{ABCP}$.

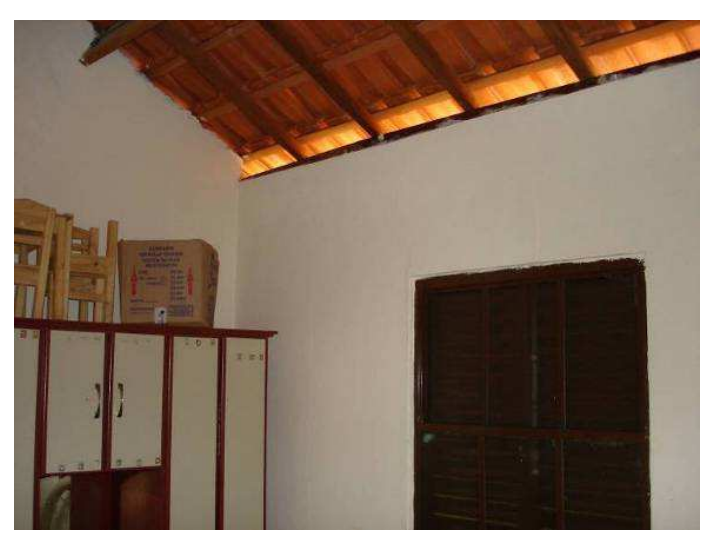

Figura 64 - Interior de casa entregue em Cunha Fonte: acervo ABCP.

\subsubsection{Sistema Construtivo: paredes de concreto celular moldadas in loco}

Neste estudo de caso, foi utilizado um sistema construtivo de paredes de concreto celular moldadas in loco regido pelas seguintes normas técnicas brasileiras:

NBR 12644:1992 - Concreto celular espumoso - Determinação da densidade de massa aparente no estado fresco.

NBR 12645:1992 - Execução de paredes de concreto celular espumoso moldadas no local.

NBR 12646:1992 - Paredes de concreto celular espumoso moldadas no local.

\subsubsection{Materiais}

O processo construtivo de paredes de concreto celular moldadas in loco é formado, basicamente, por dois materiais, o concreto e as telas metálicas de reforço, 
que são utilizados para preencher as fôrmas e formar paredes monolíticas de concreto.

\section{Concreto Celular}

No caso do Conjunto Habitacional Cunha "B", foi utilizado um concreto celular espumoso, material composto por agregados convencionais (areia e brita), cimento Portland, água, fibras de polipropileno e o agente espumígeno que gera minúsculas bolhas de ar distribuídas uniformemente em sua massa, o que the confere a propriedade de concreto leve, com massa específica menor que a dos concretos convencionais, variando entre 1.300 e $1.900 \mathrm{~kg} / \mathrm{m}^{3}$ (ABCP, 2007).

De acordo com a ABCP (2007), para habitações populares térreas os melhores resultados têm sido obtidos com densidades de massa no estado fresco de $1.500 \mathrm{~kg} / \mathrm{m}^{3}$ para paredes com espessuras de $10 \mathrm{~cm}$, que é justamente o valor adotado no Conjunto Habitacional Cunha "B". A entidade ressalta, porém, que a definição da densidade mais adequada deve ser feita com base em uma análise das propriedades mecânicas e do desempenho termo-acústico necessário.

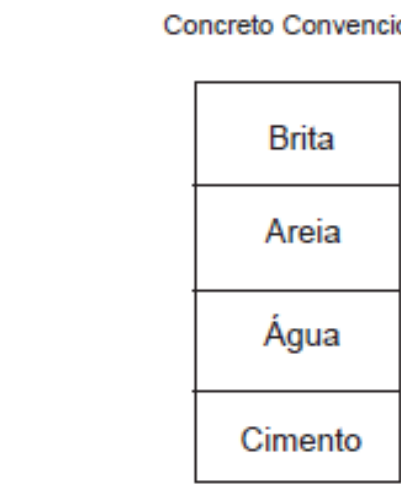

$\gamma($ densidade $)=2.400 \mathrm{kgt} / \mathrm{m}^{2}$
Concreto Celular

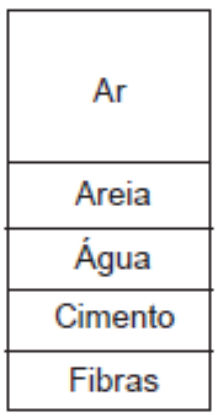

$\gamma$ (densidade) $=400$ a $1.800 \mathrm{kgf} / \mathrm{m}^{3}$

para paredes: $\gamma$ (densidade) $=1.300$ a $1.800 \mathrm{kgf} / \mathrm{m}^{3}$

Figura 65 - Comparativo entre concreto convencional e concreto celular Fonte: ABCP, 2002.

A NBR 12645 (ABNT, 1992), determina que a resistência à compressão simples do concreto deve ser maior do que $2,5 \mathrm{MPa}$ aos 28 dias, sendo que neste estudo de caso a resistência média foi de $5 \mathrm{MPa}$.

De acordo com a ABCP (2007), pode ser utilizado qualquer tipo de cimento Portland, desde que respeitadas as recomendações e limitações apresentadas pelo fornecedor do agente espumígeno. A entidade destaca, também, que o uso de 
areias de granulometria média (módulo de finura entre 2,60 e 2,70) e de britas 0 e 1 em proporções de até $20 \%$ do volume produz resultados significativos no controle da retração, sem comprometer o desempenho térmico das paredes.

Ainda segundo a ABCP (2007), a água utilizada na mistura deve ser limpa e livre de impurezas que possam prejudicar as reações do cimento ou do agente espumígeno, sendo consideradas satisfatórias as águas potáveis e as que tenham $\mathrm{pH}$ entre 5 e 8.

De acordo com a NBR 12645 (ABNT, 1992), os concretos celulares espumosos podem ser produzidos por dois processos distintos, sendo que para cada um deles há uma sequência específica para o carregamento do misturador, explica a ABCP (2007).

O método mais conhecido e aplicado é a incorporação artificial de ar no interior do concreto convencional, onde um equipamento específico (gerador de espuma) gera espuma com características controladas, que é introduzida no misturador após o preparo da argamassa, sem limites para a incorporação de ar. Outro método é a adição de um produto que, em contato com a água de amassamento e por agitação mecânica do misturador, produz as bolhas de ar necessárias para a expansão e consequente redução de massa. Neste último caso, os aditivos disponíveis restringem a incorporação de ar a cerca de $25 \%$ do volume (ABCP, 2007).

Outra forma de se obter o concreto celular é através de aeração química, que consiste em adicionar um agente químico (pó de alumínio, água oxigenada ou cal clorada) que reage com os componentes da argamassa e forma os poros necessários à expansão do volume inicial. Porém, essa opção é inviabilizada devido à alta velocidade da reação química, que acarreta na "pega" do concreto em menos de 30 minutos (ABCP, 2007).

Os agentes espumígenos podem ser de origem proteica ou sintética, mas em ambos os casos sua composição química deve ser capaz de produzir bolhas de ar estáveis no concreto, pois elas deverão resistir aos esforços gerados pela mistura, bombeamento e lançamento (ABCP, 2007).

As fibras incorporadas ao concreto celular minimizam os efeitos das tensões geradas pelas variações volumétricas decorrentes da retração por perda de umidade. Elas aumentam a resistência à tração do material, ajudam a evitar 
microfissuras localizadas e, indiretamente, melhoram a capacidade da parede em absorver esforços resultantes de impactos. As fibras mais indicadas neste caso são as do tipo multifilamento, pois permitem melhor "ancoragem" nos vazios do concreto celular (ABCP, 2007).

A dosagem do concreto celular, seja ele feito na obra ou em usina, deve ser baseada na resistência característica $\mathrm{fc}_{\mathrm{kest}}$ e na densidade de massa aparente no estado fresco especificadas pelo projetista estrutural. É recomendável a realização de testes em laboratório, utilizando os mesmos materiais e equipamentos da obra, para definir a dosagem mais adequada (ABCP, 2007).

Não é recomendada a produção do concreto celular em centrais ou usinas de concreto, pois o transporte em caminhão betoneira até o local de aplicação em percursos superiores a $3 \mathrm{~km}$ pode provocar a destruição das bolhas de ar incorporadas à mistura e o consequente aumento da massa específica do concreto (ABCP, 2007).

A forma mais eficiente de produção de concretos celulares, segundo a $A B C P$ (2007), é a partir de concretos previamente usinados e fornecidos no canteiro em caminhões betoneira para adição de bolhas de ar no local de aplicação. Neste caso, deve ser montada uma pequena central no canteiro, dotada de geradores de espuma, balança eletrônica, tambores de 200 litros, cronômetros, recipientes para medidas e estoque dos materiais (agente espumígeno, fibras de polipropileno e superfluidificante para concretos).

Sacht (2008) afirma que os concretos celulares possuem alta permeabilidade e baixa durabilidade devido ao ar incorporado à mistura, que permite o rápido ataque às armaduras por ação de íons de cloreto e carbonatação. Além disso, segundo a autora, devido aos baixos valores de resistência à compressão, é normalmente utilizado apenas em edificações térreas.

\section{Armaduras}

As armaduras, assim como as fibras, têm a função de resistir às tensões iniciais devidas à retração do concreto nas primeiras idades. Além disso, as armaduras também podem resistir a esforços ocasionais de flexo-torção nas paredes por ações externas e esforços devidos à variação da temperatura externa (ABCP, 2007). 
A ABCP (2002) recomenda a utilização de telas industrializadas de malha quadrada de pequeno diâmetro $(\varnothing 3,4 \mathrm{~mm}$, malha de $15 \mathrm{~cm} \times 15 \mathrm{~cm})$ posicionadas no eixo das paredes, além de algumas barras em pontos estratégicos (cinta superior nas paredes, vergas, contra-vergas etc.) definidos em projeto. É imprescindível o uso de espaçadores plásticos para garantir o posicionamento das armaduras e o alinhamento e espessura das paredes.

\subsubsection{O Sistema}

De acordo com a ABCP (2002), o concreto celular foi desenvolvido inicialmente em Estocolmo, Suécia, no início do século XIX, sendo utilizado na produção de isolantes térmicos para a construção civil. Era composto de argamassas de sílica e cal aeradas por um agente metálico e curado numa câmara a vapor (autoclave).

A tecnologia foi aprimorada com o desenvolvimento dos concretos celulares espumosos, que são mais leves devido à incorporação de ar. Inicialmente usado para isolamento térmico, preenchimento de vãos de lajes e na proteção mecânica de camadas impermeabilizantes, com o tempo foi ganhando outras aplicações. Hoje, esses concretos são utilizados para a construção de paredes portantes de edifícios e vedação de casas térreas e sobrados, sendo muito eficaz devido ao seu grau de isolamento térmico. Além disso, esses concretos são autoadensáveis, dispensando vibração e preservando a vida útil das fôrmas (ABCP, 2007).

$O$ processo de paredes de concreto tradicional moldadas in loco foi utilizado em 1980 pela COHAB, na cidade de Poços de Caldas e no início da década de 80 foram executadas as primeiras edificações com paredes de concreto celular moldadas in loco no Brasil, tendo sido pioneiras as cidades de Natal/RN e Manaus/AM (BOIN, 2003; SACHT, 2008). De acordo com Boin (2003), nas décadas de 80 e 90 foram executadas cerca de 40.000 unidades habitacionais no país, impulsionadas por vantagens como o grau de conforto térmico interno e a rapidez de sua execução.

Essa experiência de 20 anos na construção de casas levou ao desenvolvimento da técnica construtiva e da tecnologia do concreto celular. Boin (2003) afirma, no entanto, que essa fase de experiências nem sempre gerou resultados de melhor qualidade, devido ao desconhecimento, o que fez com que o 
processo ficasse mal visto pelo mercado. $\mathrm{O}$ autor atribui esses maus resultados a erros de execução e projeto, além da falta de controle tecnológico nos canteiros de obras, mas afirma que a difusão do conceito de qualidade nos últimos anos pode contribuir para a mudança desse cenário.

O fato é que, com seus erros e acertos, "a experiência obtida na construção dessas casas levou a um aprimoramento da técnica, com o emprego de fôrmas modulares racionalizadas, e a uma grande melhoria do produto final" (ABCP, 2002). Este processo construtivo apresenta diversas vantagens, como facilidade e rapidez de execução, controle tecnológico rigoroso, facilidade de treinamento da mão de obra, possibilidade de redução da espessura do revestimento e de ampliação, gerando uma significativa economia (ABCP, 2007).

Segundo Boin (2003), as paredes devem ser executadas de acordo com o projeto, que deve detalhar o posicionamento das esquadrias, instalações elétricas e hidrossanitárias de modo que não haja sobreposição e interferências que impeçam a execução desses elementos.

De acordo com a ABCP (2007), podem ser adotados diversos tipos de fundações nesse processo, sendo a escolha de responsabilidade do projetista. É importante, porém, que as fundações apresentem, além de segurança e durabilidade, o alinhamento e o nivelamento necessários para a produção das paredes.

A ABCP (2007) recomenda que as fundações tenham um excedente de pelo menos $5 \mathrm{~cm}$ além das faces da parede, permitindo o apoio e a montagem dos painéis das fôrmas. De acordo com esta entidade, as fundações tipo radier têm a vantagem de deixar as instalações posicionadas no piso e de proporcionar uma base de trabalho apropriada para as equipes de montagem das fôrmas.

O sistema de fôrmas utilizado no empreendimento Cunha "B" era constituído de painéis modulados de chapa de madeira compensada revestidos com filme de grande resistência, reforçados com estrutura metálica tipo grelha. De acordo com Boin (2003), a estrutura metálica garante a resistência mecânica necessária para suportar as tensões geradas pelo concreto.

Esses painéis possuem modulação de $5 \mathrm{em} 5 \mathrm{~cm}$, com dimensões e peso que permitem o fácil manuseio e transporte. Os módulos se encaixam de acordo com a 
sequência determinada em projeto, por meio de grampos metálicos especiais que conferem rigidez ao conjunto (ABCP, 2002).

Todo conjunto de fôrmas deve vir acompanhado de seu projeto, pois este apresenta o posicionamento de cada painel e o detalhamento da montagem (ABCP, 2007). Boin (2003) afirma, ainda, que o projeto de fôrmas deve passar por uma rigorosa análise crítica por parte do responsável pela obra e é indispensável para o início dos serviços.

De acordo com a ABCP (2007), o concreto celular perde água rapidamente, principalmente em regiões de grande variação de temperatura e umidade do ar, o que gera o fenômeno de redução de volume do concreto, ou retração. A retração do concreto gera esforços de tração que podem levar ao seu rompimento, criando fissuras ao longo da superfície das paredes.

Para controlar esse fenômeno, a NBR 12645 (ABNT, 1992) estabelece o emprego de armaduras contínuas (barras de aço, telas eletrossoldadas ou não) ou descontínuas (fibras metálicas, sintéticas ou naturais). Outros cuidados, como execução de juntas de construção e de controle de retração, podem ser tomados, sendo sempre indicados no projeto (ABCP, 2007).

De acordo com Boin (2003), todas as paredes da habitação podem ser moldadas em uma única etapa de concretagem, permitindo que, após a desforma, já contenham em seu interior todos os elementos embutidos, tais como: esquadrias, tubulações elétricas e hidráulicas, elementos de fixação para cobertura etc.

As instalações podem ser fornecidas em kits pré-montados e são posicionadas e fixadas nas fôrmas e armaduras com auxílio de espaçadores para impedir seu deslocamento durante a concretagem. Segundo a ABCP (2007), as ligações de água devem ser testadas em bancadas dotadas de redes com pressão, o que permite detectar falhas antes do seu embutimento nas paredes. Caixas ou tubulações que apresentem espaços em que possa entrar concreto devem ser preenchidas com papel ou pó de serra, impedindo a obstrução desses elementos (ABCP, 2007). Cabe lembrar, no entanto, que este procedimento de embutimento de instalações hidráulicas utilizado nas casas de Cunha não é mais recomendado, pois a manutenção dessa tubulação exige a quebra das paredes estruturais.

A ABCP (2007) afirma que o concreto leve adota a forma do vaso que o contém, dentro dos princípios clássicos da mecânica dos fluídos, portanto, o uso de 
vibradores ou adensadores neste caso é inadequado, pois destrói as bolhas de ar, internas à massa, provocando o aumento de sua densidade (ABCP, 2007).

Ainda de acordo com a ABCP (2007), o lançamento do concreto celular obedece a um critério de escolha de pontos, de modo que este possa preencher todos os vazios sem quaisquer dificuldades. Depois de realizada a mistura, o concreto celular espumoso deve ser lançado em no máximo 30 minutos, não excedendo a altura de 2 metros de queda livre do concreto.

A desforma é realizada após um período mínimo de 12 horas, que pode ser maior de acordo com as condições térmicas do local (ABCP, 2007).

Após executadas, as paredes devem se apresentar niveladas, alinhadas e aprumadas, sendo que o sistema de fôrmas deve garantir desvios inferiores a $3 \mathrm{~mm}$ em relação ao plano da parede (BOIN, 2003).

O processo de cura, que é o conjunto de ações que visa evitar a evaporação prematura da água necessária à hidratação do cimento e o consequente aparecimento de fissuras devidas à retração, deve ser sempre realizado logo após a desforma. A NBR 12645 (ABNT, 1992) especifica dois métodos de cura para as paredes de concreto celular, a cura por molhagem, onde deve ser realizada a molhagem do concreto com água e sacos úmidos por no mínimo três dias, e a cura por aplicação de membranas impermeáveis, que devem ser removidas antes da aplicação do revestimento.

De acordo com a ABCP (2007), a feltragem é uma operação realizada algumas horas após a desforma das paredes e consiste na aplicação de uma camada de nata de cimento Portland, com traço rico em cimento, por meio de desempenadeiras de madeira revestidas com espuma. Essa operação visa retirar os sinais superficiais da fôrma, reduzir a porosidade superficial, tamponar os pequenos poros e bolhas de ar superficiais e melhorar o aspecto das paredes. No caso de as paredes apresentarem uma superfície lisa e isenta de irregularidades, é possível realizar uma feltragem parcial apenas nos pontos mais desfavoráveis.

Uma das grandes vantagens das paredes de concreto é a possibilidade de redução da espessura das camadas de revestimento, sendo que não há restrições quanto à utilização de qualquer tipo de revestimento, desde que seguidas as especificações e restrições do fornecedor. Podem ser utilizados, por exemplo, tintas, massa corrida, revestimentos cerâmicos, texturas e argamassas industrializadas 
(ABCP, 2007). A fixação de elementos de acabamento ou decorativos deve ser realizada através de fixação com buchas e parafusos (ABCP, 2002).

É importante salientar que ao longo destes 9 anos posteriores à realização desse empreendimento, os processos de construção que utilizam paredes de concreto moldadas in loco já sofreram grandes transformações. Neste período, houve um grande desenvolvimento dos sistemas de fôrmas e da tecnologia do concreto aplicada ao sistema, tanto do concreto celular quanto do concreto tradicional. Assim, muitos procedimentos utilizados na execução do empreendimento estudado, e relatados aqui, já obtiveram significativas melhorias.

\subsubsection{Procedimentos de execução}

Antes de iniciar a execução, é preciso verificar a compatibilidade entre o cronograma geral de execução e a quantidade de conjuntos de fôrmas necessários, além de planejar o reaproveitamento das fôrmas para a execução sequencial das unidades. Durante o recebimento das fôrmas, é preciso conferir todas as peças entregues e relacionadas no projeto executivo de montagem para que não falte nada durante a execução, assim como as ferramentas e equipamentos necessários (ABCP, 2007).

As unidades habitacionais do Conjunto Habitacional Cunha " $B$ " foram construídas de acordo com os procedimentos a seguir (ABCP, 2002; ABCP, 2007):

\section{Etapa 1: Execução do radier}

Execução de fundação tipo radier deixando todas as esperas e tubulações de água, esgoto, elétrica etc. É importante que o piso esteja perfeitamente nivelado para evitar diferenças de nível no topo dos painéis e, consequentemente, a descontinuidade no alinhamento superior das paredes. 

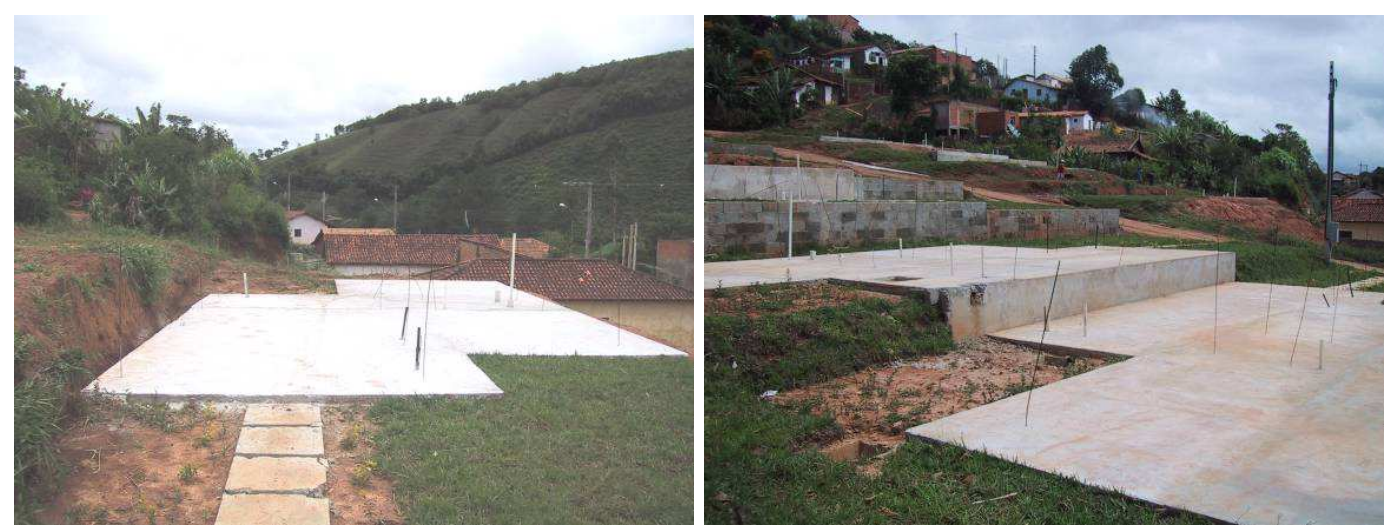

Figura 66 - Execução dos radiers em Cunha Fonte: acervo ABCP.

\section{Etapa 2: Marcação das paredes e montagem das fôrmas internas}

Inicialmente, marcam-se as linhas das faces internas e externas das paredes na fundação e em seguida os módulos das fôrmas são encaixados de acordo com a sequência determinada no projeto, mantendo as aberturas de portas para permitir a circulação dos operários durante a execução. É recomendável começar a montagem dos painéis pela parede hidráulica, colocando-se primeiro os painéis de canto, formando um "L", e depois os painéis da face interna da parede hidráulica. Os painéis são montados em sequência, de ambos os lados, e conectados com o uso de grampos, sempre deixando uma face livre para as instalações das redes elétrica e hidráulica. Ao longo da montagem, são posicionadas escoras prumadoras para manter os painéis em pé e garantir o prumo das paredes. Por fim, são colocadas as ancoragens metálicas responsáveis por absorver as pressões do concreto e garantir que as fôrmas não se abram.

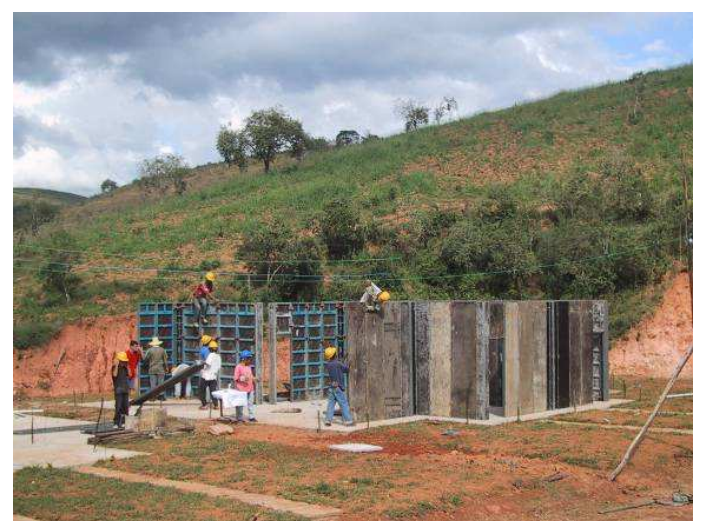

Figura 67 - Montagem dos painéis internos Fonte: acervo $A B C P$. 


\section{Etapa 3: Fixação das armaduras e elementos de esquadrias}

As armaduras e os elementos das esquadrias (batentes de portas, contramarcos de janelas ou esquadrias completas) são embutidos nos painéis das fôrmas simultaneamente à sua montagem. Todos os elementos de esquadrias devem ter espessura igual ou inferior à largura das paredes. As armaduras, constituídas de telas metálicas industrializadas no eixo das paredes e de algumas barras em pontos estratégicos, são posicionadas com a ajuda de espaçadores plásticos.

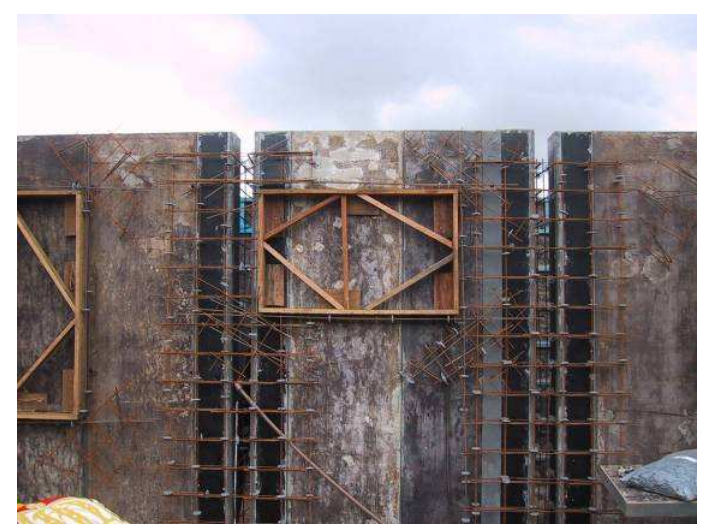

Figura 68 - Fixação das armaduras e elementos de esquadrias Fonte: acervo ABCP.

\section{Etapa 5: Montagem das instalações}

No sistema adotado nas casas de Cunha, as instalações elétricas e hidráulicas são embutidas nas paredes de concreto. Todas as instalações são posicionadas e fixadas nas fôrmas e armaduras, sempre utilizando espaçadores entre elas e a face dos painéis de fôrma.

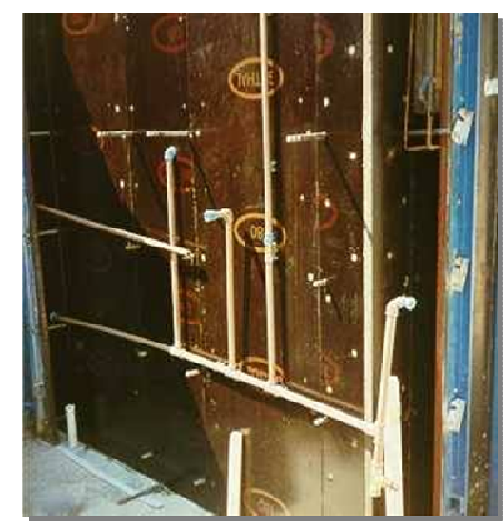

Figura 69 - Montagem das instalações Fonte: acervo ABCP. 


\section{Etapa 6: Fechamento das fôrmas}

Uma vez posicionadas e fixadas as armaduras, esquadrias, e instalações, as fôrmas são fechadas. Para tanto, é montado o outro plano dos painéis.
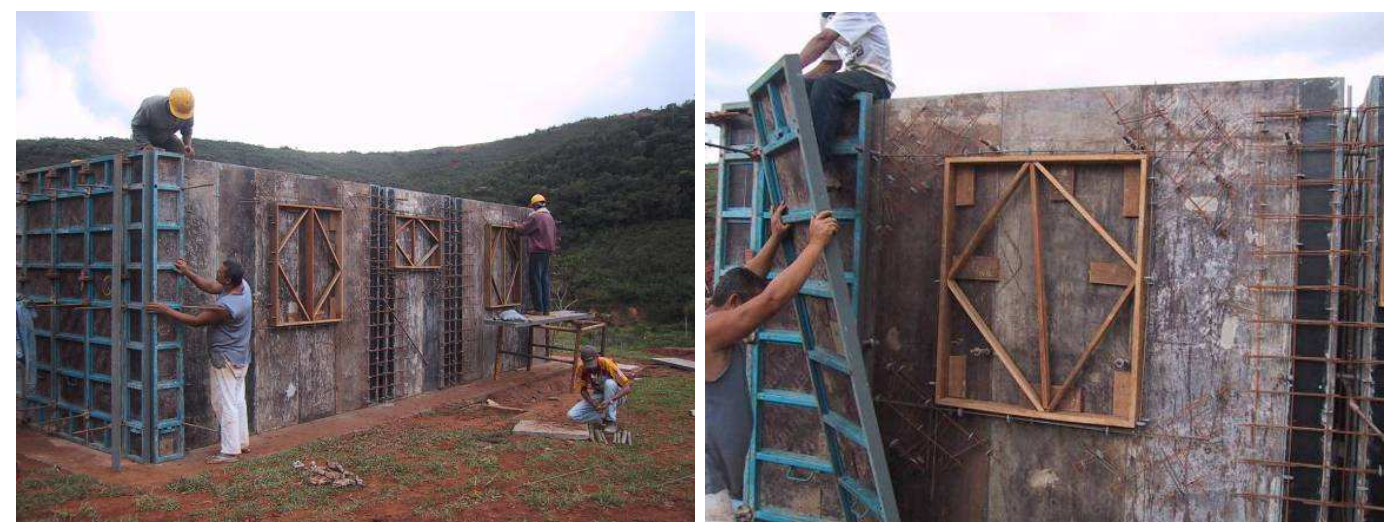

Figura 70 - Fechamento dos painéis de fôrmas Fonte: acervo ABCP.

\section{Etapa 7: Concretagem das paredes e lajes}

Uma vez dosado e preparado o concreto celular, este deve ser transportado até o local de aplicação. O lançamento deve começar por um dos cantos da edificação até que grande parte das paredes mais próximas esteja completamente preenchida. Depois, muda-se o lançamento para o canto oposto e para os demais cantos até que os quatro cantos da casa sejam concretados. Em seguida, é feito o posicionamento das armaduras e instalações das lajes e a sua concretagem.
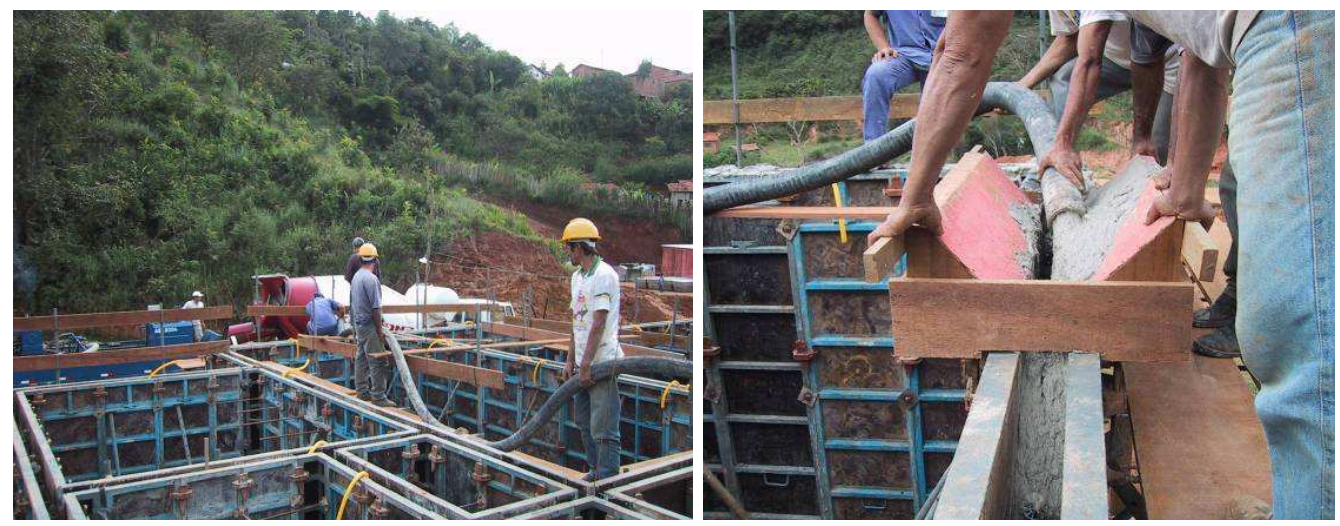

Figura 71 - Concretagem das paredes

Fonte: acervo ABCP. 


\section{Etapa 8: Desforma e acabamento do concreto}

A desforma deve começar pelos painéis internos e depois são desmontados os painéis externos. Em seguida, é feita a remoção de rebarbas do concreto, além do preenchimento dos furos de ancoragem com argamassa de cimento e areia e eventuais reparos necessários. Em seguida, realiza-se a feltragem.

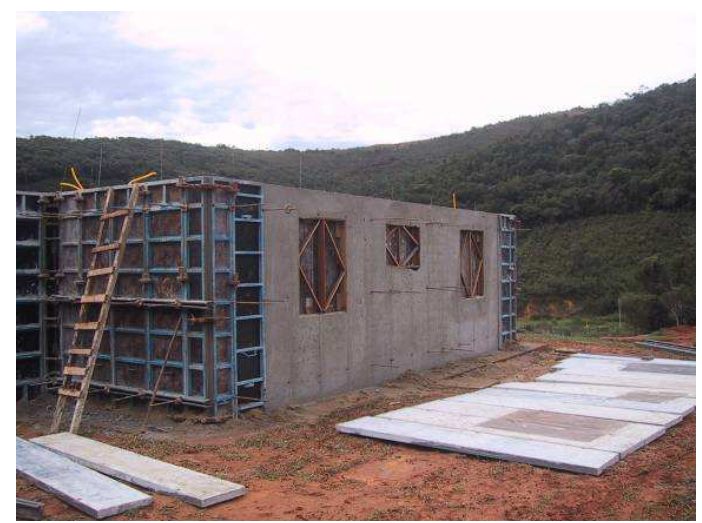

Figura 72 - Desforma das paredes

Fonte: acervo ABCP.

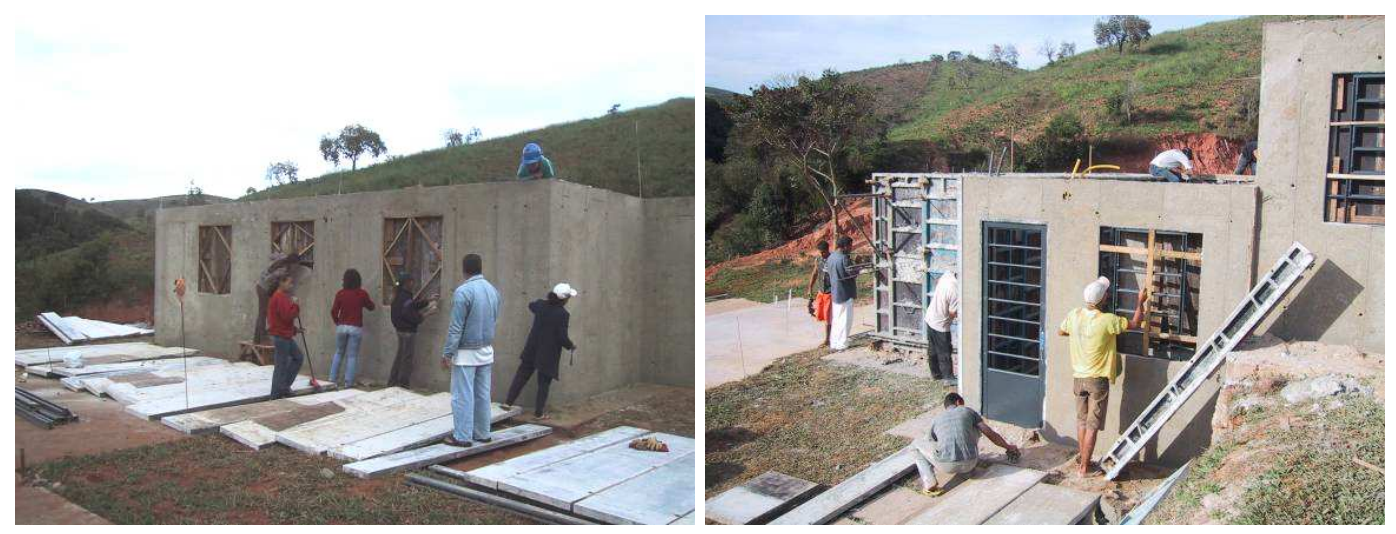

Figura 73 - Acabamento do concreto após a desforma Fonte: acervo ABCP.

\section{Etapa 9: Cura do concreto}

A cura pode ser realizada por molhagem ou por aplicação de membranas impermeáveis. No caso de Cunha, foi adotado o processo de molhagem.

\section{Etapa 8: Execução dos oitões}

No caso específico de Cunha, os oitões foram executados com blocos de concreto. 


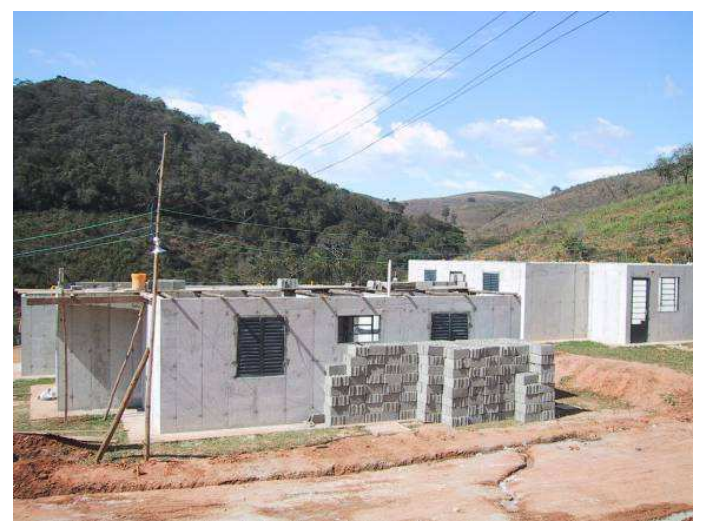

Figura 74 - Preparação para execução dos oitões em alvenaria Fonte: acervo ABCP.

\section{Etapa 10: Execução da cobertura}

Execução da estrutura de madeira e do telhamento com telhas cerâmicas.

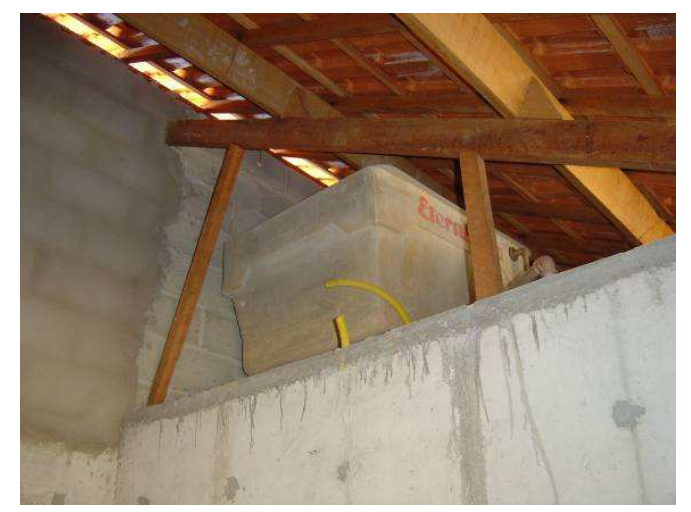

Figura 75 - Cobertura com estrutura de madeira e telhas cerâmicas Fonte: acervo ABCP.

\section{Etapa 11: Revestimento e acabamentos}

Aplicação de pintura externa com textura acrílica hidrorrepelente e interna com látex PVA sobre massa corrida. Os oitões receberam revestimento com argamassa. 

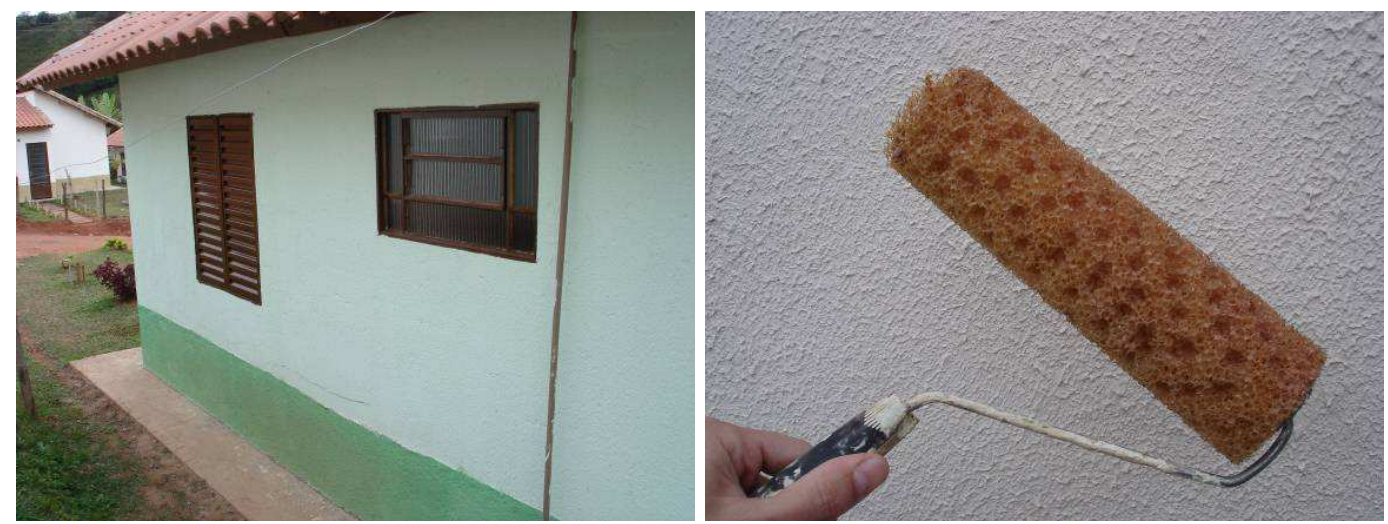

Figura 76 - Revestimento externo com textura Fonte: acervo ABCP.
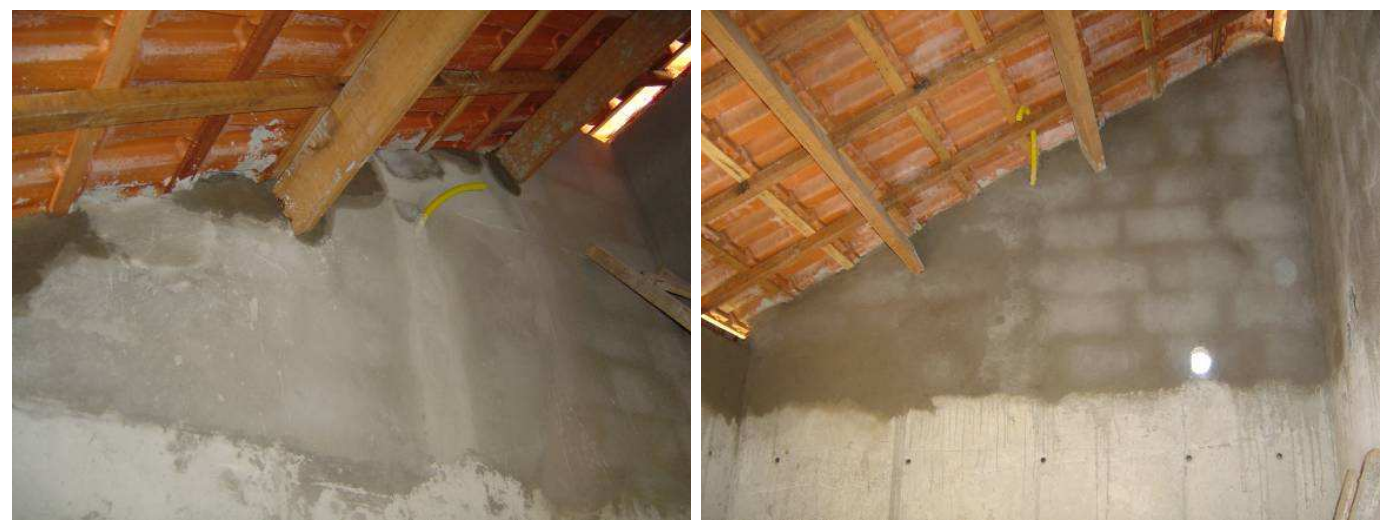

Figura 77 - Revestimento dos oitões com argamassa Fonte: acervo $\mathrm{ABCP}$.

\subsubsection{Aplicação em moradia popular}

Este processo tem sido muito utilizado para a construção de unidades habitacionais populares, sejam elas promovidas pelos órgãos públicos ou por empresas privadas, por apresentar diversas vantagens, como a facilidade e rapidez de execução, a facilidade de treinamento da mão de obra, o controle tecnológico rigoroso e a consequente economia.

De acordo com a ABCP (2007), também é possível realizar a ampliação das casas com procedimentos semelhantes aos de outros sistemas construtivos. Para tanto, podem ser utilizados blocos de concreto ou tijolos cerâmicos assentados com argamassa na construção de novas paredes. É recomendável, no entanto, que as possíveis ampliações sejam previstas ainda na fase de projeto, de forma que sejam incorporadas armaduras complementares para os vãos abertos posteriormente para portas e janelas. 
É importante, também, que os moradores recebam um manual do usuário com as informações necessárias para a realização de ampliações, tais como uma planta baixa, especificação de materiais, forma de ligação das paredes de concreto com as paredes novas etc. (ABCP, 2007).

\subsection{O Estudo de caso}

Foram realizadas duas visitas ao empreendimento Cunha "B", sempre contando com dois pesquisadores, para entrevistar os moradores e colher informações sobre as casas e modificações realizadas após a entrega destas pela CDHU.

As 10 unidades habitacionais visitadas foram nomeadas com a sigla $\mathrm{CNH}$, que identifica o empreendimento, e os números de 01 a 10 , sendo que cada uma delas recebeu um nome de $\mathrm{CNH01}$ a $\mathrm{CNH} 10$, na ordem de realização das visitas.

As visitas foram realizadas em dois dias distintos, sendo que na primeira ocasião a temperatura estava elevada, em torno de $30^{\circ}$, e choveu no final da tarde, porém, por um período curto e com baixa intensidade. A segunda visita foi realizada apenas no período da manhã, com temperatura amena, mas é interessante comentar que no final da tarde do dia anterior a região havia passado por uma forte tempestade que durou cerca de uma hora.

\subsubsection{Apresentação e Análise dos Resultados das Entrevistas}

Para a realização de entrevistas com os moradores, foi utilizado um formulário padrão, cujo modelo é apresentado no Apêndice $B$, entretanto, ressalta-se que a planta apresentada nesse modelo não é do Conjunto Habitacional Cunha "B".

As entrevistas mostraram que o número de moradores nas casas visitadas varia de 2 a 5, com uma média 3,5 moradores por unidade habitacional.

A totalidade das casas visitadas ainda está financiada e $70 \%$ das famílias entrevistadas moram no imóvel desde a entrega, sendo que $20 \%$ são a segunda família a habitar o imóvel e $10 \%$ são a terceira família a fazê-lo.

Assim como no primeiro estudo de caso, observou-se que todas as residências contam com os bens de consumo básicos, como fogão, geladeira, 
televisão e chuveiro elétrico. O gráfico a seguir apresenta a porcentagem de famílias que possui cada bem de consumo:

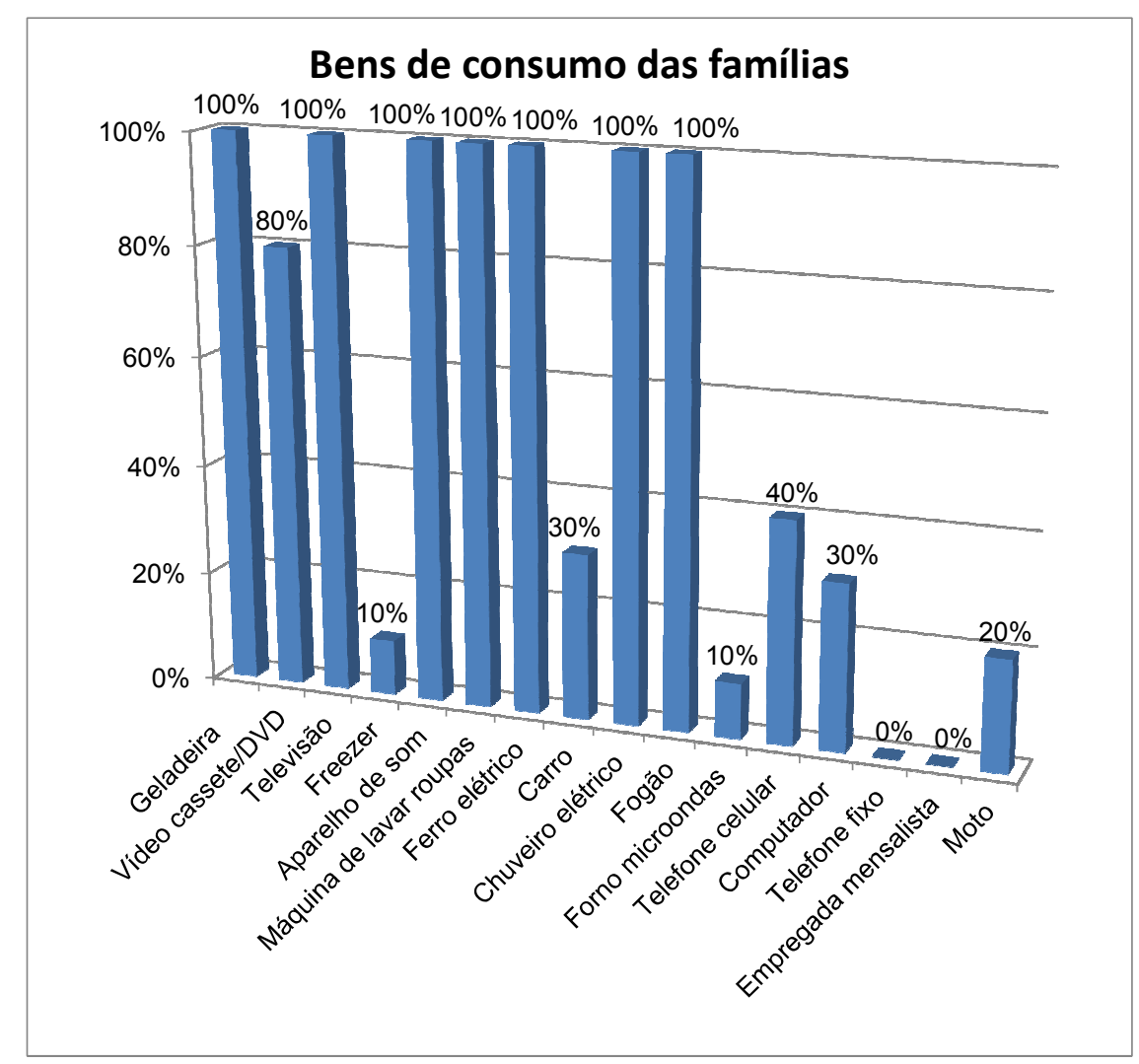

Gráfico 21 - Estudo de Caso 2: Bens de consumo das famílias

Quando perguntados se consideram que a casa foi entregue completa, $70 \%$ dos moradores entrevistados consideram que não, $20 \%$ consideram que sim e uma moradora não quis opinar porque a casa já estava bastante modificada quando ela passou a morar lá. A grande porcentagem de moradores que responderam não se deve, com certeza, ao fato de as casas terem sido entregues sem o acabamento completo, sobretudo o piso e o forro. Alguns moradores afirmam, ainda, que receberam as casas sem a pintura interna e sem os vidros das esquadrias. Poucos moradores reclamaram de receber as casas sem muros.

Ainda assim, todos os entrevistados consideram que a casa entregue atende a todas as necessidades da família e relatam gostar das casas e ter orgulho delas, principalmente depois de feitas as modificações que eles consideravam fundamentais. Apesar desse resultado, foram muitas as reclamações com relação ao fato de a sala e a cozinha não serem separadas fisicamente, o que, segundo eles, 
espalha gordura e cheiro de fritura por toda a casa. Outra reclamação recorrente foi pelo fato de as casas serem geminadas, o que reduz a privacidade da família ao passo que se pode ouvir o que se passa na casa vizinha, principalmente porque não há laje em toda a casa.

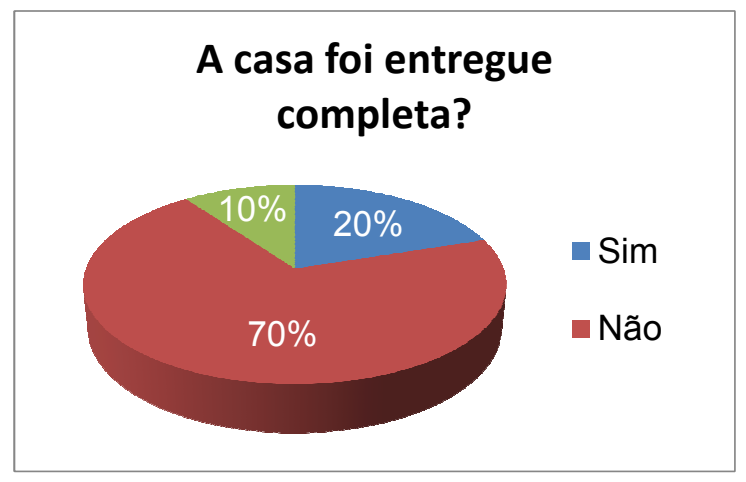

Gráfico 22 - Estudo de Caso 2: Avaliação da casa recebida

Dentre os entrevistados, $90 \%$ relataram a ocorrência de algum tipo de problema construtivo ou patologias, sobretudo trincas e infiltração nas paredes. Uma moradora comentou que acredita que a ocorrência dessas patologias se deve ao fato de os próprios moradores terem construído as casas e ela acha que deveria ter sido contratada uma empresa especializada para a construção dos imóveis.

Do total de entrevistados, $60 \%$ afirmam ter problemas com umidade e infiltração, mas sem presença de mofo.

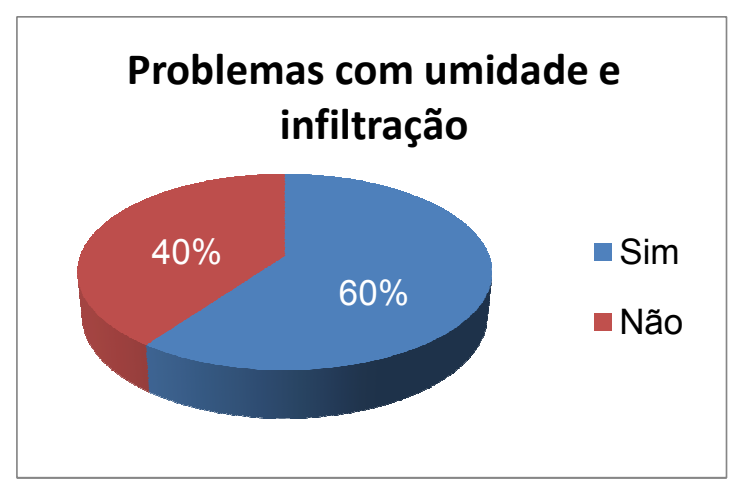

Gráfico 23 - Estudo de Caso 2: Problemas com umidade e infiltração

Dentre os moradores que relataram problemas com umidade e infiltração, todos afirmam que o problema está no topo das paredes, sendo que destes, $20 \%$ afirmam ter problemas também na região das paredes próximas ao piso. 
Já com relação à iluminação e ventilação, as avaliações dos moradores foram boas, chegando a $90 \%$ de avaliações boas no quesito iluminação e $100 \%$ no quesito ventilação.

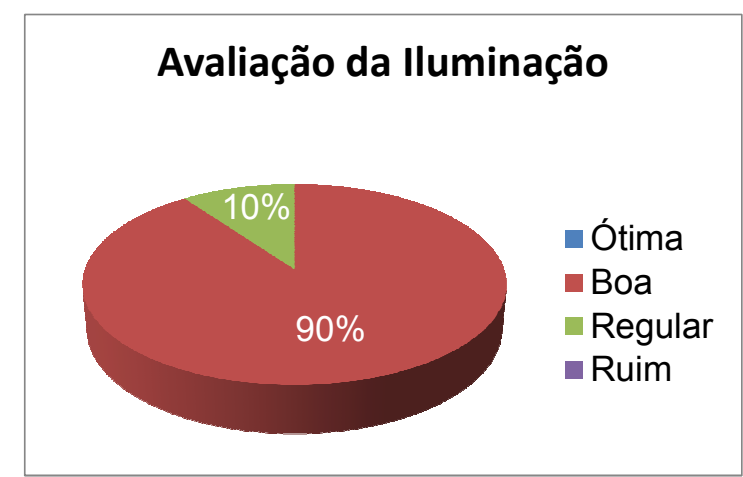

Gráfico 24 - Estudo de Caso 2: Avaliação da iluminação

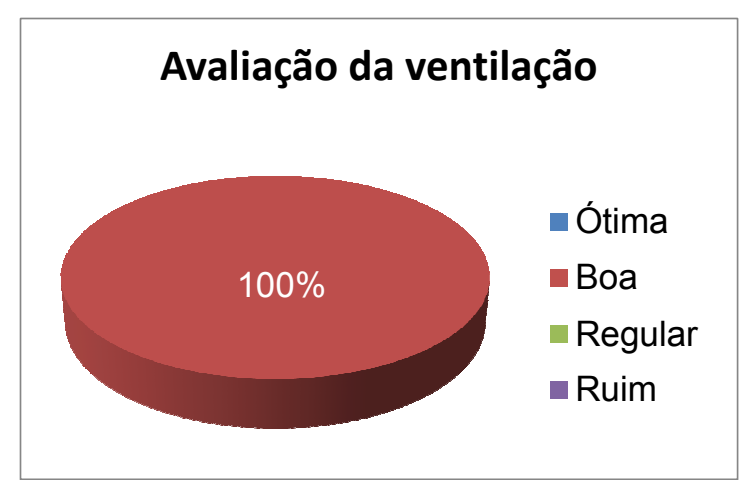

Gráfico 25 - Estudo de Caso 2: Avaliação da ventilação

Verificou-se, também, que todas as casas sofreram algum tipo de modificação após a entrega, o que pode ser facilmente explicado pelo fato de as casas terem sido entregues sem o acabamento completo. Segundo os moradores, não foi fornecido nenhum tipo de projeto ou orientação para a realização de reformas e ampliações nas casas.

Essas modificações foram realizadas, em sua maioria, por pedreiros contratados, sendo que apenas $10 \%$ dos entrevistados afirmaram que as modificações foram feitas por algum membro da família, parentes ou amigos. Constatou-se, também, que essas modificações foram sendo realizadas ao longo do tempo e que em mais de $80 \%$ dos casos a última modificação foi realizada há mais de um ano, como indicam os gráficos a seguir:

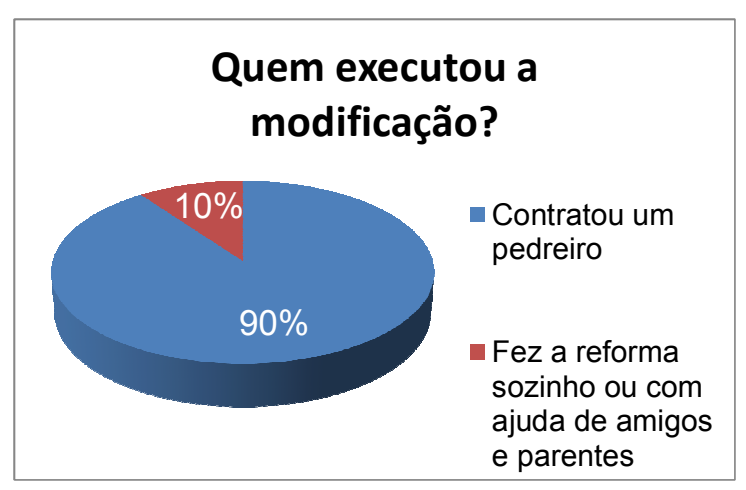

Gráfico 26 - Estudo de Caso 2: Agente realizador das modificações 


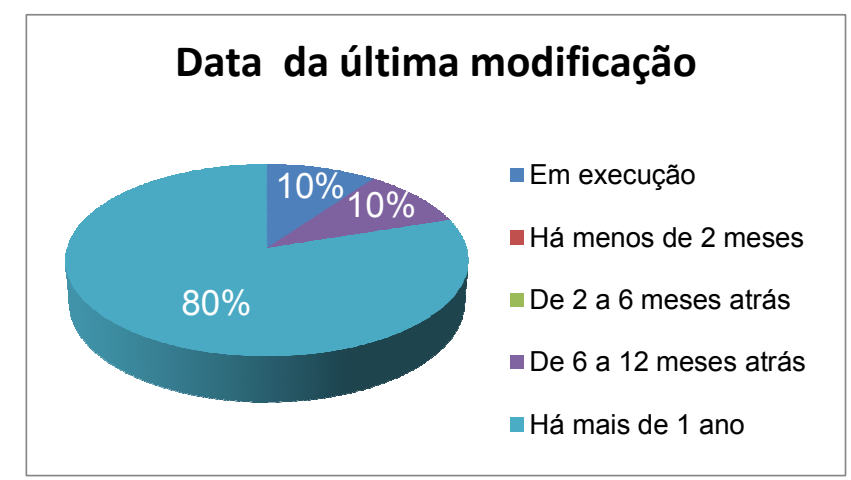

Gráfico 27 - Estudo de Caso 2: Data da última modificação

Todas as famílias entrevistadas fizeram modificações na sala, cozinha, dormitórios e área de serviço, $90 \%$ fizeram modificações no banheiro e no quintal e $60 \%$ na garagem, como mostra o gráfico 28 , a seguir:

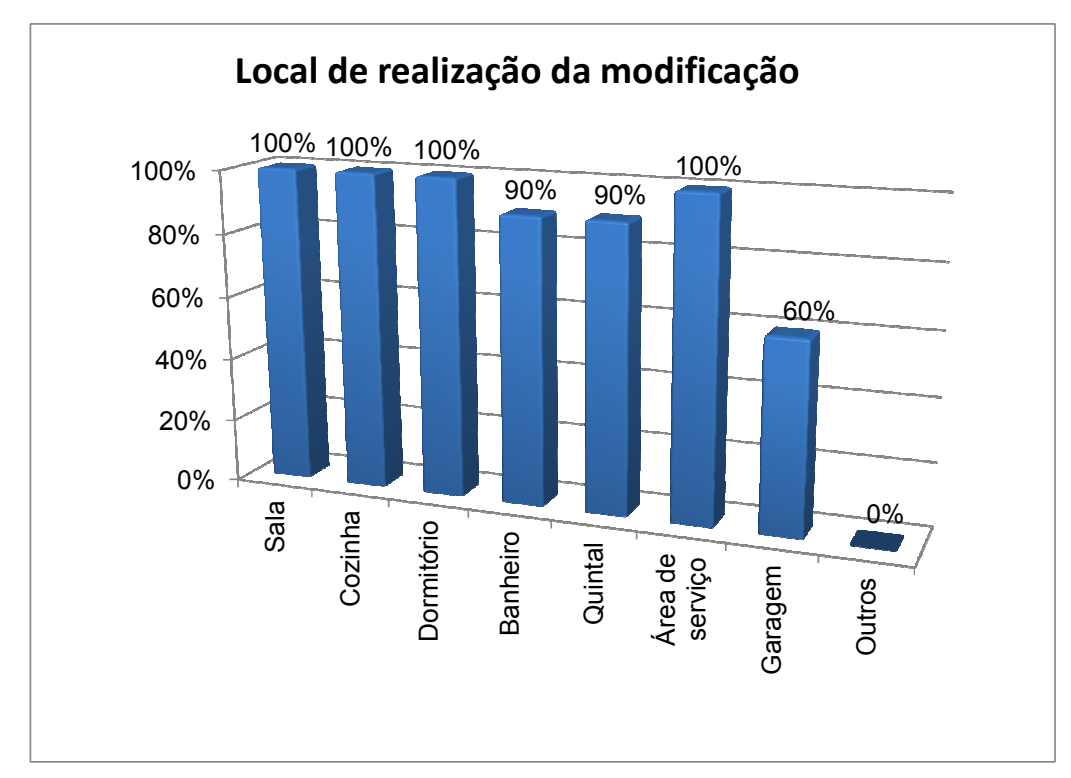

Gráfico 28 - Estudo de Caso 2: Local de realização das modificações

A totalidade das famílias entrevistadas fez modificações na cobertura, piso e azulejos, além de construir muros e portões. O gráfico 29 , a seguir, apresenta todos os itens modificados e a porcentagem de famílias que modificou cada um: 


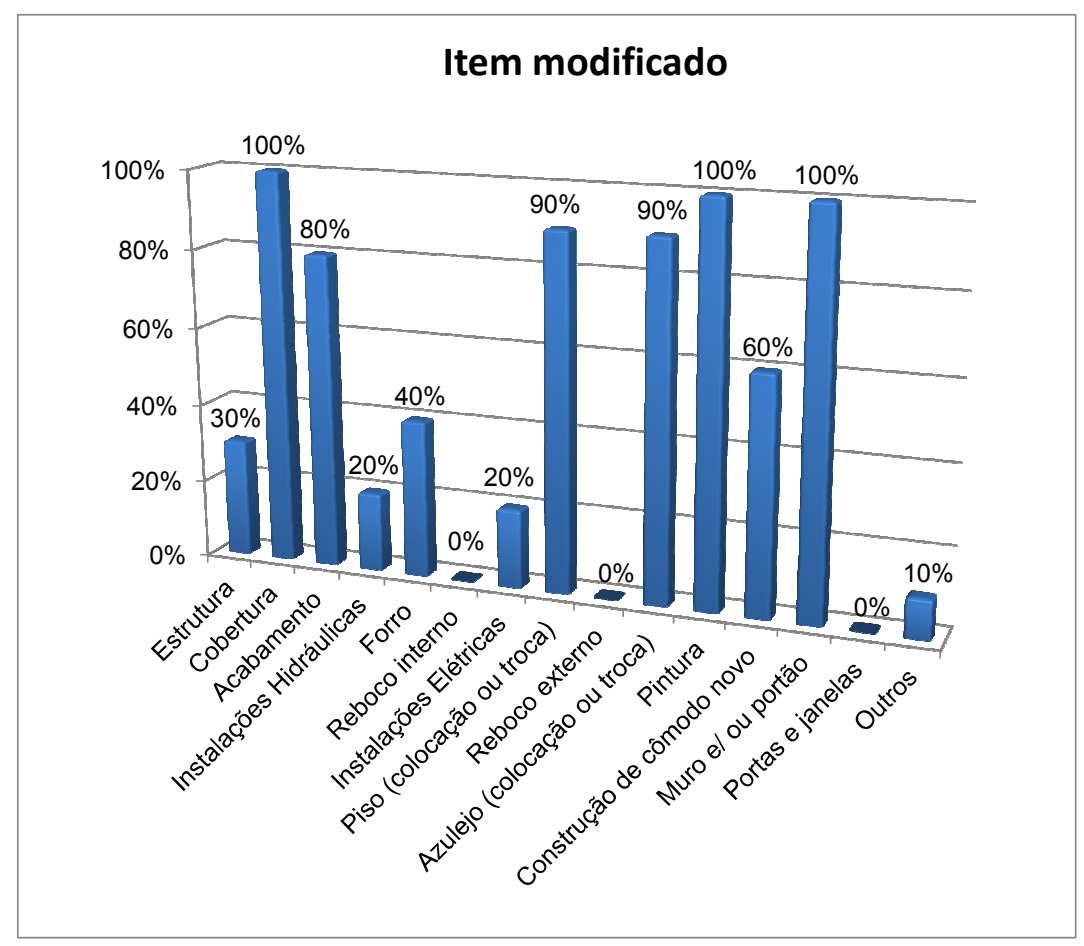

Gráfico 29 - Estudo de Caso 2: Itens modificados

A maioria dos moradores afirmou não ter encontrado dificuldades técnicas para a realização das modificações. Aqueles que afirmaram ter tido dificuldades, citaram como empecilhos a necessidade de quebrar as paredes para consertar instalações elétricas e hidráulicas e uma moradora comentou que as paredes da casa eram "tortas" e que foi difícil regularizá-las.

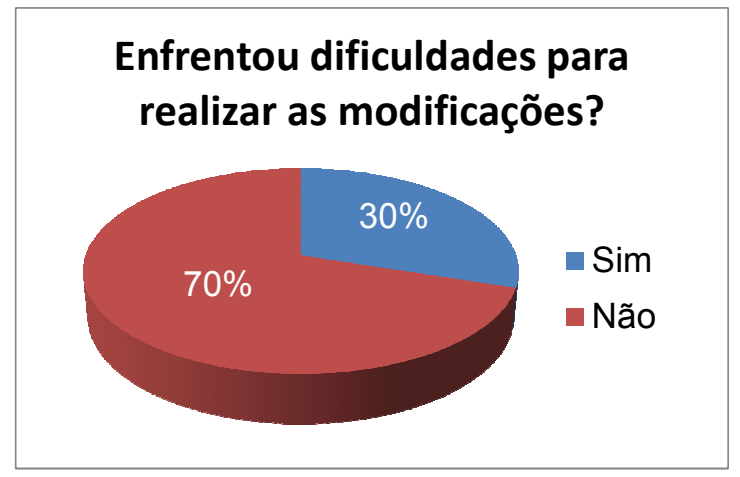

Gráfico 30 - Estudo de Caso 2: Dificuldades para realizar modificações

Quando perguntados se têm a intenção de realizar alguma modificação na casa futuramente, $60 \%$ dos entrevistados afirmaram que SIM, como indicado no gráfico a seguir: 


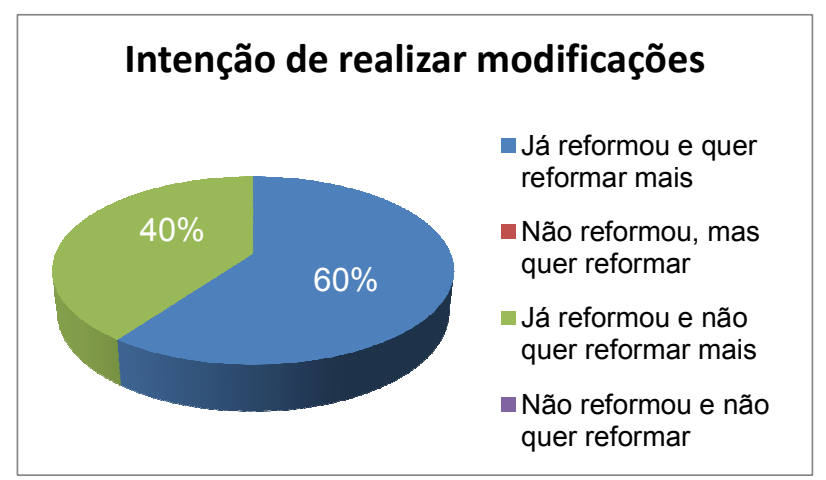

Gráfico 31 - Estudo de Caso 2: Intenção de modificar o imóvel

Ao ser interrogada sobre a intenção de realizar novas modificações na casa, uma moradora comentou que não compensa investir muito nessa casa porque, segundo ela, a localização dela é ruim, muito longe do centro, e esse investimento não será recuperado no caso de venda do imóvel. Outra moradora comentou que o bairro é ruim e violento e que a localização não é muito valorizada por ser longe do centro, apesar de estar a menos de $2 \mathrm{~km}$ de lá.

Dos moradores que pretendem realizar modificações, 33\% consideram que a reforma é urgente.

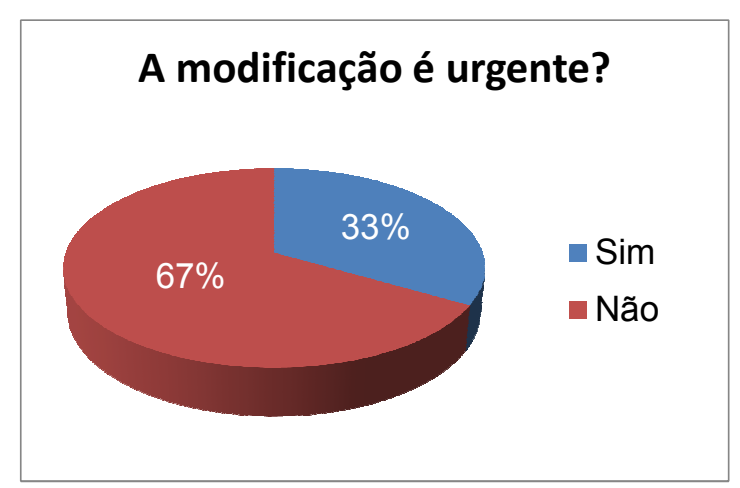

Gráfico 32 - Estudo de Caso 2: Urgência das modificações

Assim como no primeiro estudo de caso, o principal desejo dos moradores é a construção de um cômodo novo, item citado por $50 \%$ dos entrevistados, que relataram o desejo de construir um dormitório ou uma cozinha. Também foi citada a intenção de fazer modificações na cobertura, piso, muros e portões. Dois entrevistados comentaram, ainda, que desejam construir varandas na frente da edificação. Uma moradora relatou a necessidade de construir um muro de arrimo nos fundos do lote devido a um desbarrancamento e outra moradora diz ter a 
intenção de fazer modificações na casa, mas ainda não sabe exatamente o que vai modificar.

Os gráficos 33 e 34 mostram as intenções dos moradores quanto às novas modificações a serem realizadas, destacando os ambientes a serem modificados e o tipo de serviço a ser executado, respectivamente.

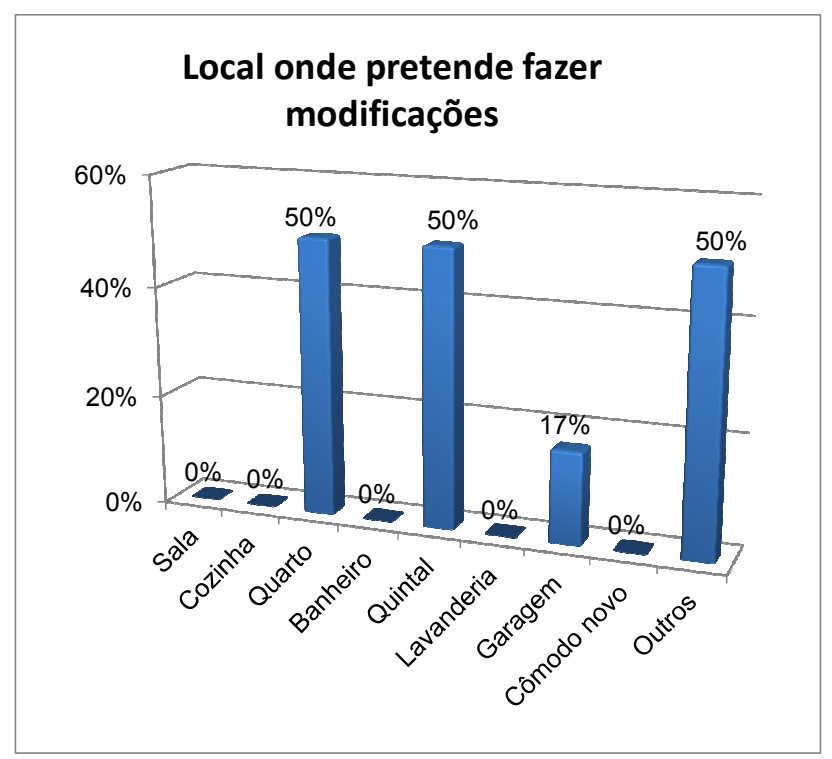

Gráfico 33 - Estudo de Caso 2: Local que pretende modificar

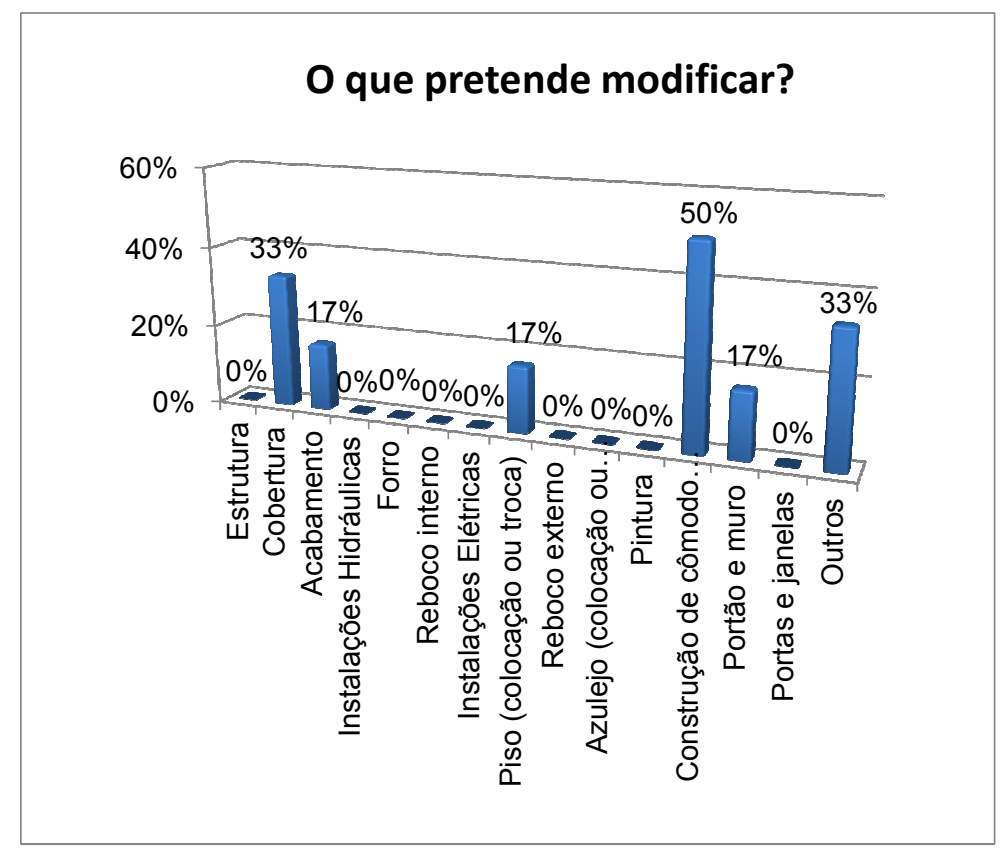

Gráfico 34 - Estudo de Caso 2: Serviços que pretende realizar 
Para os moradores, o maior benefício das modificações realizadas ou intencionadas é a ampliação da casa, seguido pelo aumento da segurança e pela melhoria da aparência da residência. O gráfico 35, a seguir, apresenta os resultados completos dos benefícios das modificações citados pelos moradores:

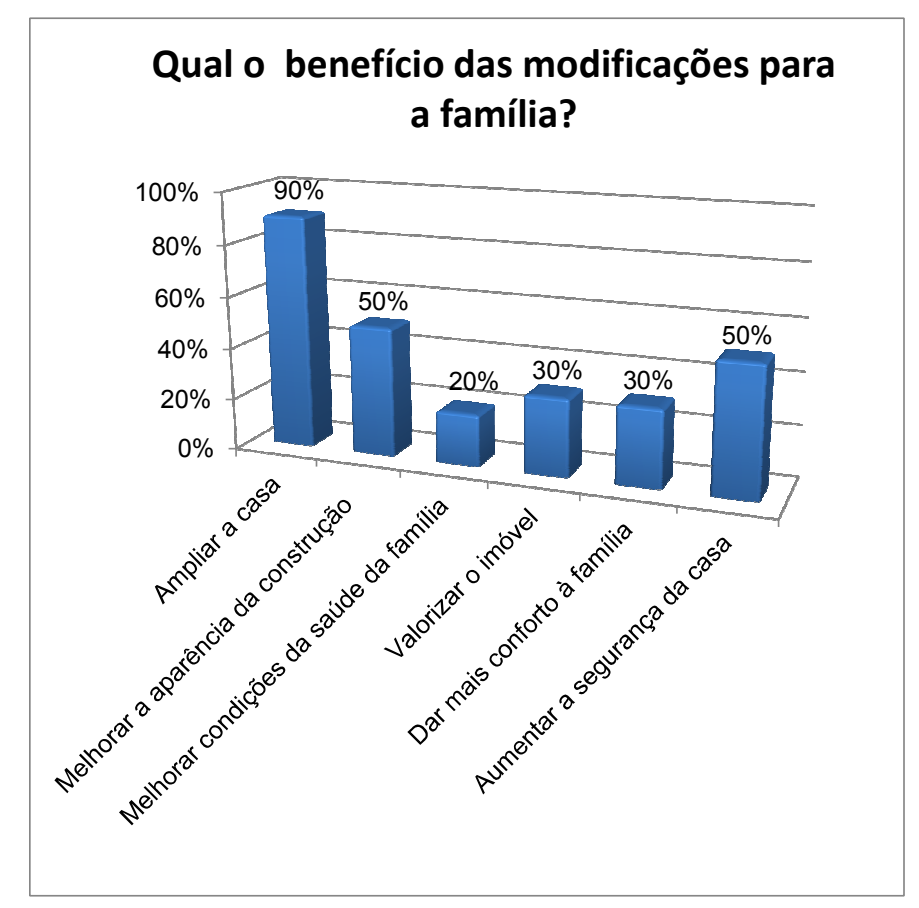

Gráfico 35 - Estudo de Caso 2: Benefício das modificações

\subsubsection{Apresentação e Análise dos Resultados da Avaliação Técnica}

Após as entrevistas, foi realizada uma avaliação técnica dos imóveis através de visita aos cômodos das casas, em compania de um ou mais moradores.

Das famílias visitadas, todas construíram muro e apenas uma delas não colocou portão na frente do lote. 

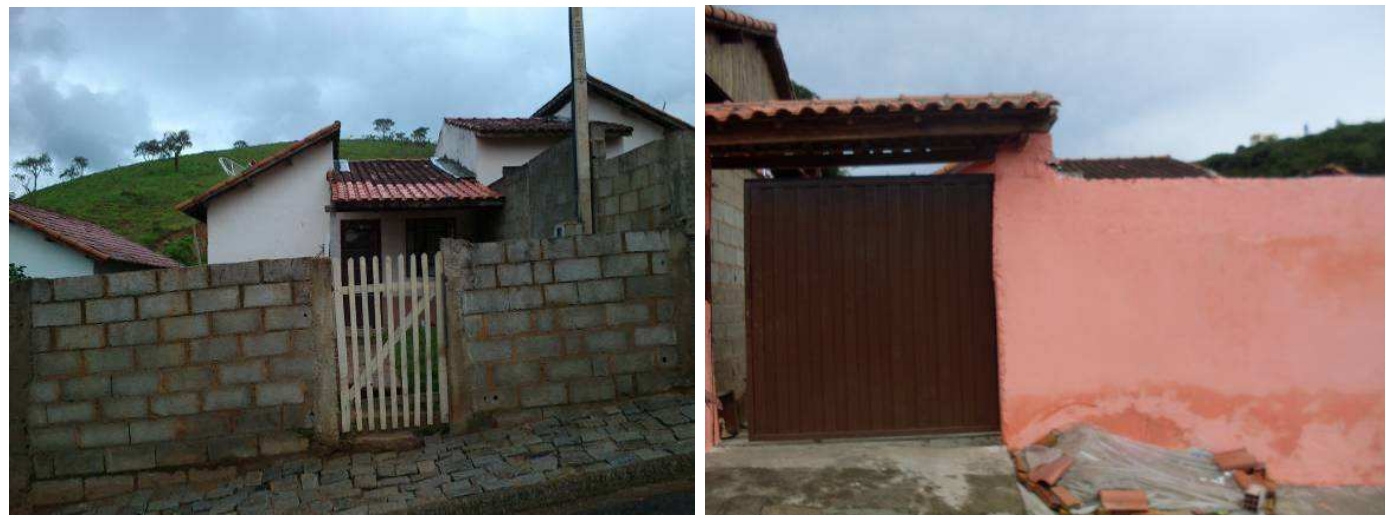

Figura 78 - Exemplos de fachadas de casas com muros e portões Fonte: a autora.

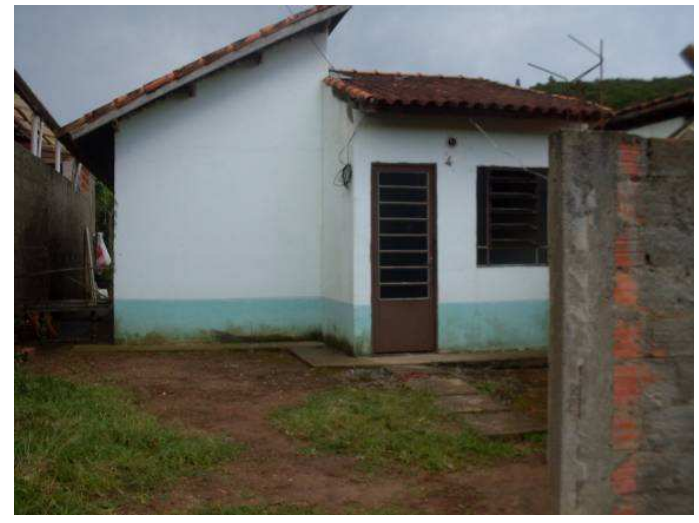

Figura 79 - Fachada da casa que executou apenas o muro Fonte: a autora.

Verificou-se que algumas famílias ainda fizeram outras alterações no quintal. Das 10 casas visitadas, 7 tiveram o lote totalmente cimentado, sendo que em uma delas também foi aplicado piso cerâmico em toda a área externa do lote. Em uma das casas foi feito piso cimentado apenas na frente do lote e em outras duas não foi feito piso algum.

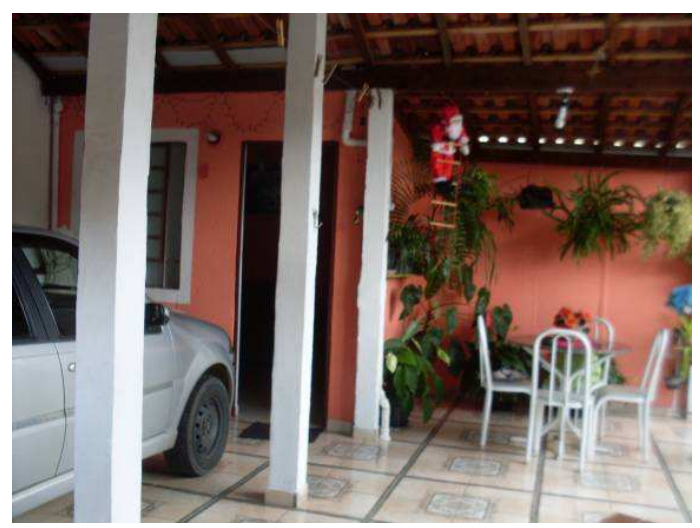

Figura 80 - Frente da CNH05 com piso e cobertura Fonte: a autora. 
No geral, o terrapleno apresenta boas condições, mas três lotes, localizados ao norte da Rua Um, tiveram a parte dos fundos atingida por um pequeno desbarrancamento, sendo a casa $\mathrm{CNH06}$ a mais atingida.

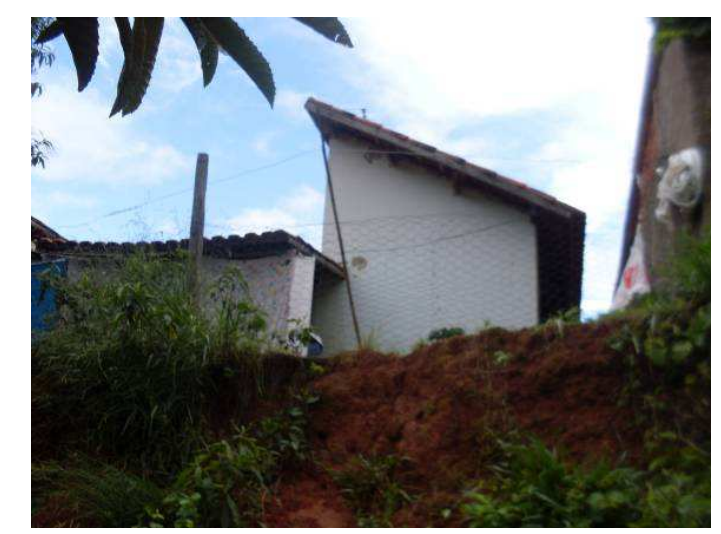

Figura 81 - Desbarrancamento do terreno nos fundos da CNH06 Fonte: a autora.

O muro da casa $\mathrm{CNH01}$ apresenta trincas que podem sugerir acomodação do aterro. Segundo a moradora, essas trincas já foram reparadas com argamassa, mas reapareceram.

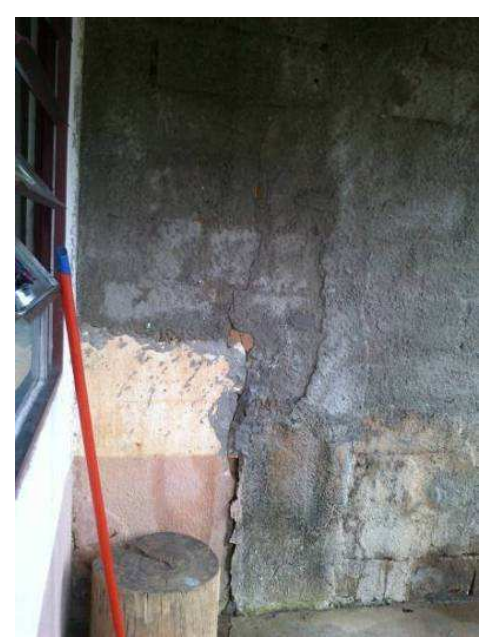

Figura 82 - Trincas no muro da CNHO1

Fonte: a autora.

As unidades têm fundação do tipo radier, porém, essas estruturas encontramse total ou parcialmente inacessíveis, sem sinais de anomalias.

A estrutura é composta por paredes de concreto celular moldadas in loco e laje maciça apenas sobre o banheiro e o corredor de acesso aos dormitórios. Foram encontradas trincas e fissuras nas paredes de todas as unidades, com exceção da 
casa $\mathrm{CNH07,} \mathrm{que} \mathrm{foi} \mathrm{reformada} \mathrm{recentemente} \mathrm{e} \mathrm{teve} \mathrm{suas} \mathrm{trincas} \mathrm{e} \mathrm{fissuras}$ reparadas com argamassa. Outros moradores também relataram já ter realizado reparos com argamassa nas paredes, mas em todos os casos as trincas e fissuras reapareceram parcial ou totalmente depois de algum tempo.

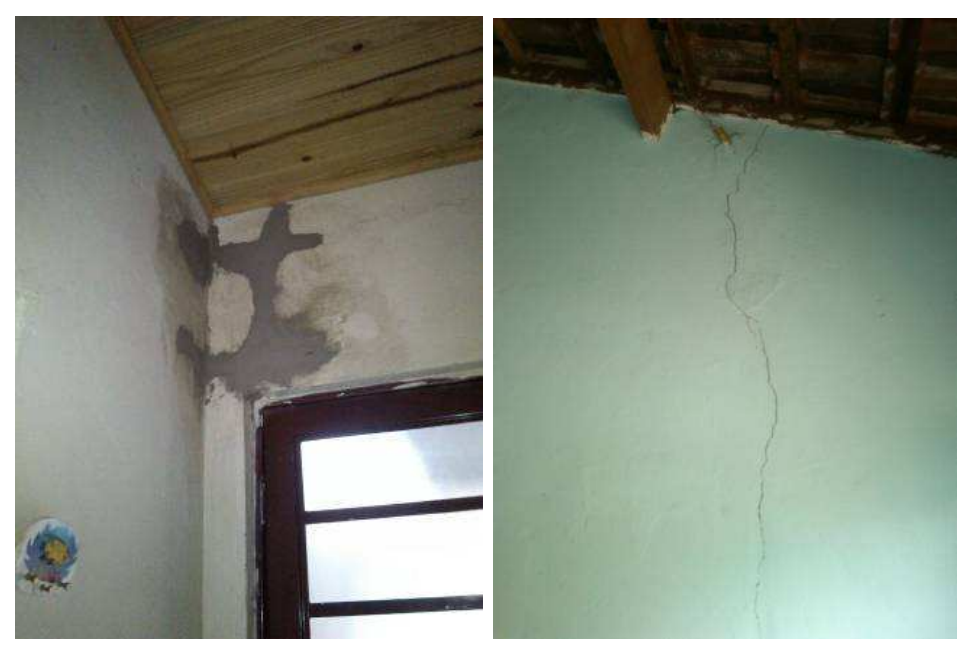

Figura 83 - Reparo na CNH01 e trinca na CNH10

Fonte: a autora.

Cinco das dez casas visitadas apresentam sinais de infiltração nas paredes, sendo que todos esses moradores relatam a ocorrência de infiltração no mesmo local, na parede entre a sala e o dormitório, próximo ao quadro de luz. Outros moradores afirmam ter tido esse problema e dizem que ele foi resolvido após a selagem das telhas com argamassa junto à parede e instalação de rufo no telhado. Não foram observadas anomalias nas lajes dos banheiros e corredores.
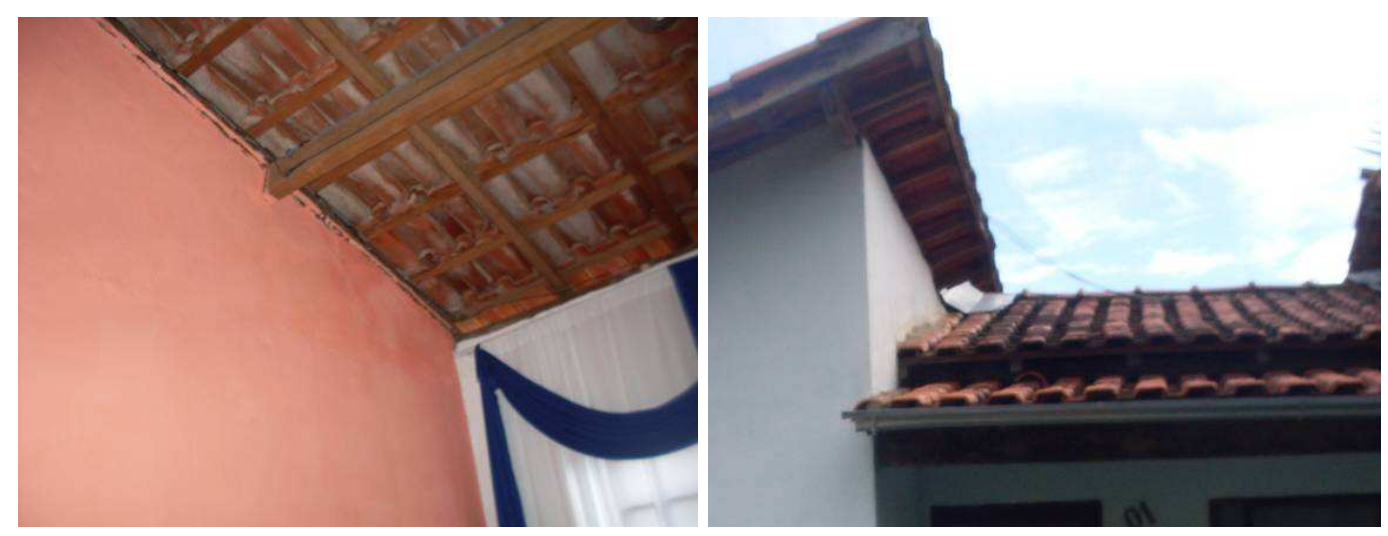

Figura 84 - Infiltração na CNH04 e reparo com rufo na CNH08

Fonte: a autora. 
Em seis das dez casas visitadas foram construídos cômodos adicionais após a entrega. Dessas, quatro famílias construíram cozinhas novas nos fundos, duas construíram um dormitório a mais e duas construíram cômodos destinados a despensa e realização de atividades manuais, como costura e bordado.

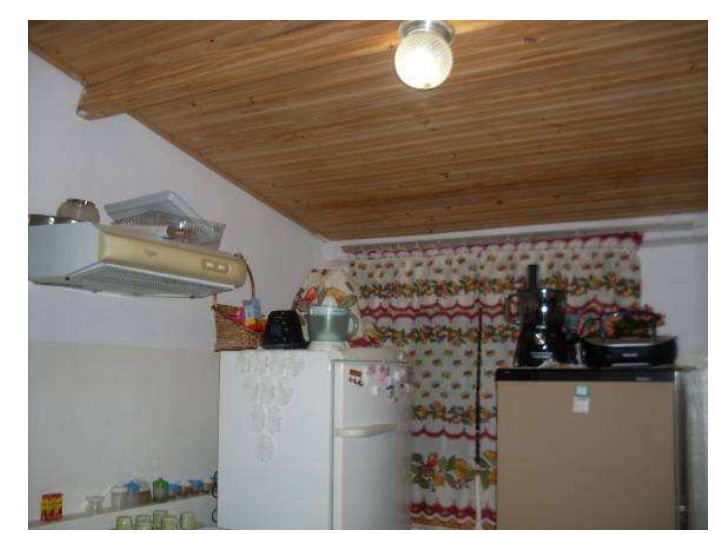

Figura 85 - Cozinha nova na CNH05

Fonte: a autora.

As próprias paredes de concreto cumprem também a função de vedação, sendo que nas seis casas onde foram construídos cômodos adicionais, foram utilizados tijolos cerâmicos tipo "baiano" para a execução das novas vedações e algumas dessas paredes apresentam sinais de infiltração.

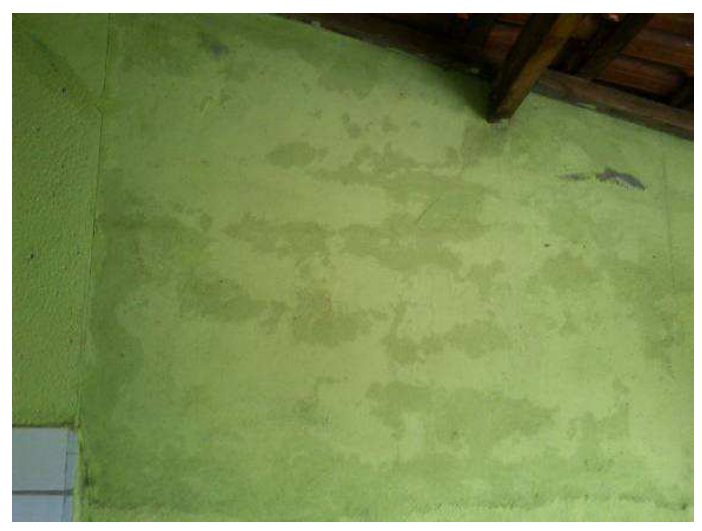

Figura 86 - Sinais de umidade na alvenaria da CNH09 Fonte: a autora.

Em geral, esses novos cômodos construídos pelos moradores não têm qualquer tipo de elemento estrutural, sendo que as alvenarias funcionam como estrutura e vedação e não há laje. Em alguns casos, esses novos elementos apresentam sinais de umidade. Apenas na casa $\mathrm{CNH} 10$, foi executada uma laje na 
cozinha construída posteriormente pelos moradores, sendo que esta apresenta sinais de infiltração, como é possível observar na figura 87.

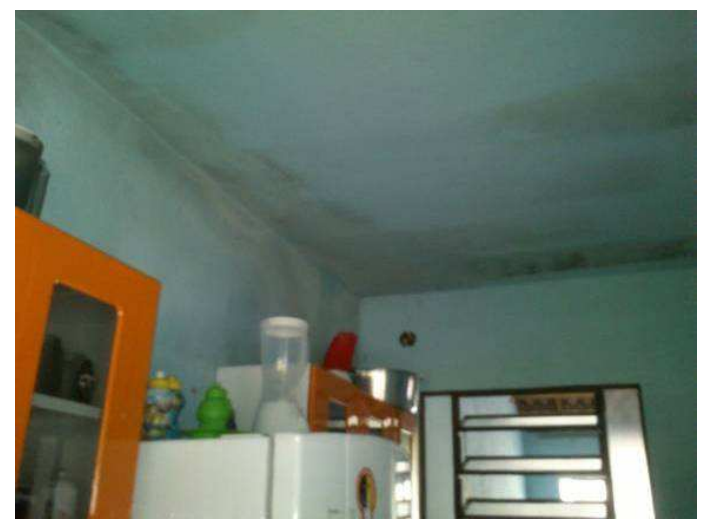

Figura 87 - Infiltração na laje da cozinha nova da CNH10 Fonte: a autora.

Metade das casas visitadas conta com muretas ou balcões dividindo a sala e a cozinha, constituídos de alvenaria de tijolinhos de barro maciços ou de tijolos cerâmicos tipo "baiano", conforme figura 88. Em uma residência foi construída uma parede de tijolos cerâmicos tipo "baiano" separando esses ambientes, apresentando trincas nas duas extremidades, na interface com a parede de concreto (figura 89).
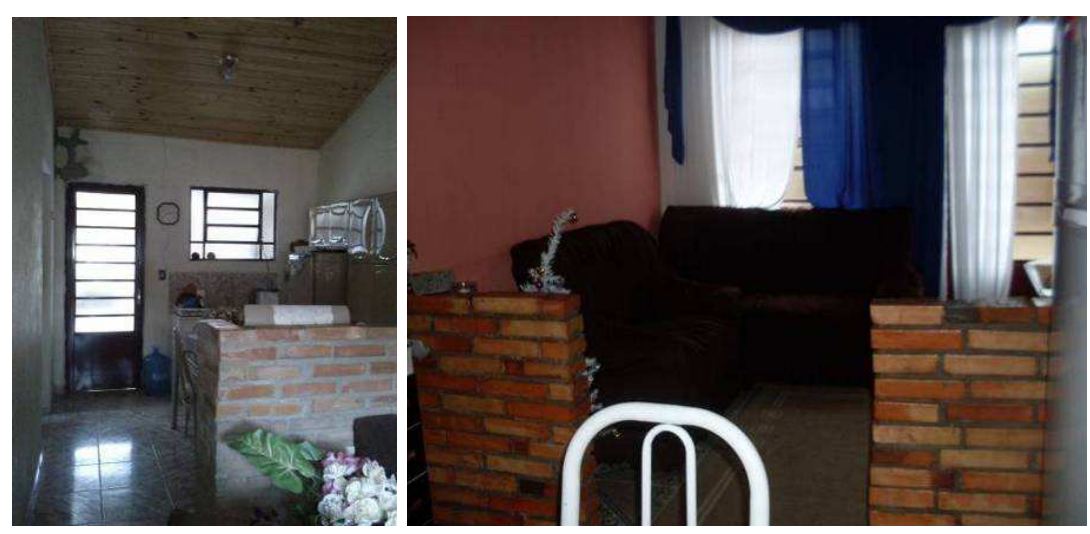

Figura 88 - Balcão na CNH01 e muretas de alvenaria na CNH04 Fonte: a autora. 


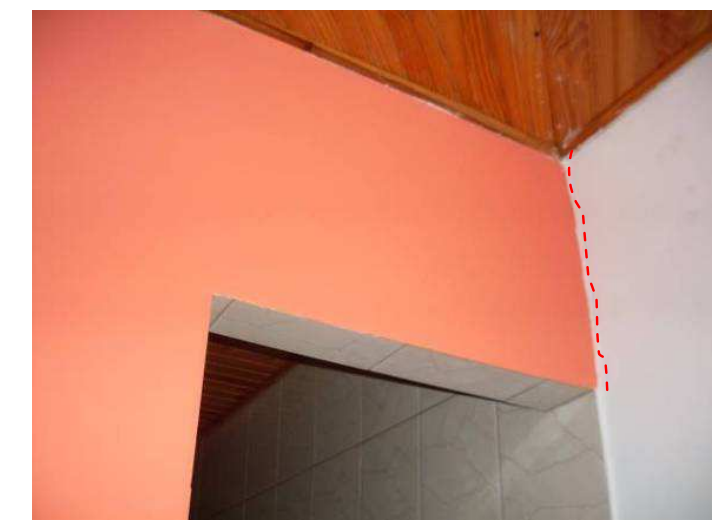

Figura 89 - Trinca na ligação da parede nova com a antiga na CNH05 Fonte: a autora.

Todas as casas visitadas fizeram cobertura na área de serviço, sendo que o tamanho destinado às atividades de serviço varia bastante. Em duas casas foram construídas muretas de alvenaria de tijolos cerâmicos tipo "baiano" para separar a área de serviço do quintal e, nos dois casos, essas muretas apresentam sinais de umidade.

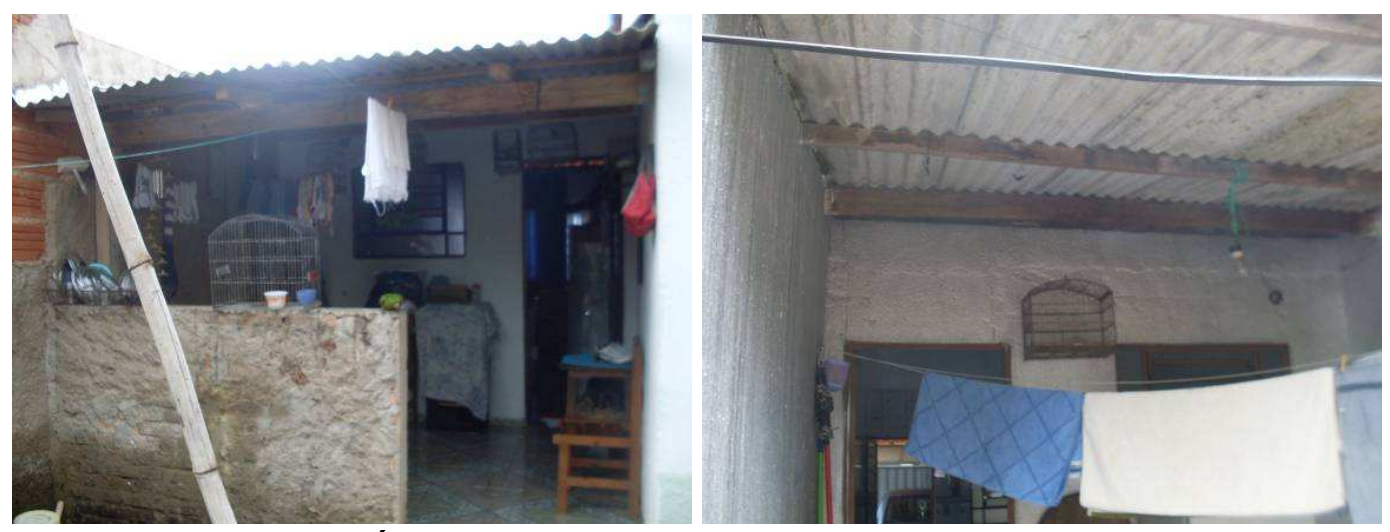

Figura 90 - Área de serviço da CNHO4 e CNH07, respectivamente.

Fonte: a autora.

A cobertura é composta de estrutura de madeira e telhas cerâmicas, em geral em boas condições, sendo que apenas uma moradora reclamou de goteiras em um ponto específico da casa. Em geral, as coberturas realizadas posteriormente pelos moradores, seja para garagens ou para cômodos novos, foram feitas com estrutura de madeira e telhas cerâmicas ou de fibrocimento. Algumas famílias instalaram forro de madeira ou PVC em toda a casa. 


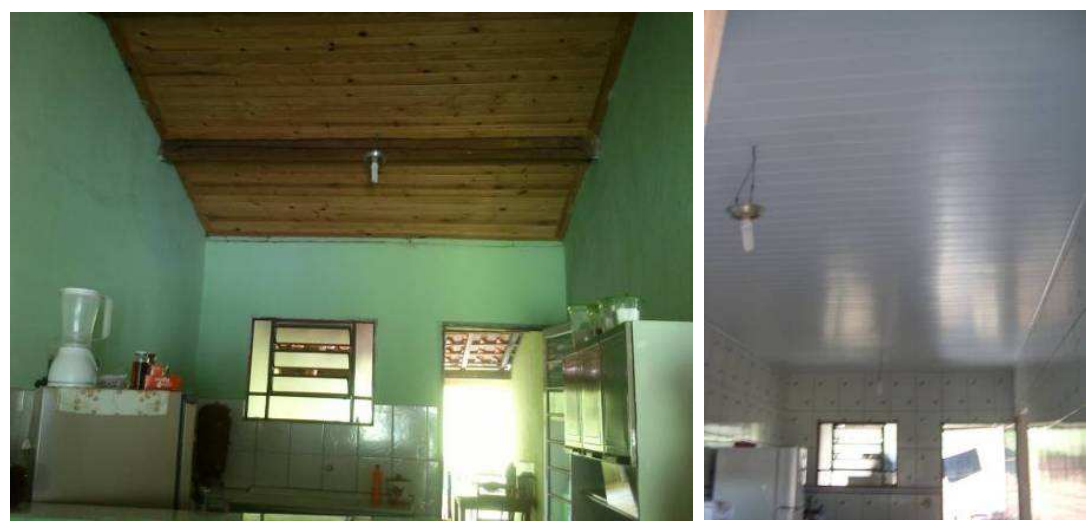

Figura 91 - Forro de madeira na CNH09 e de PVC na CNH07

Fonte: a autora.

Observou-se, ainda, que seis famílias construíram varandas na frente do lote e três as construíram também nos fundos, como uma extensão da área de serviço, onde é possível observar a presença de fornos a lenha e moedores de café. Quatro casas contam com garagem coberta e em uma casa foi construído um canil com muros altos na frente do lote.

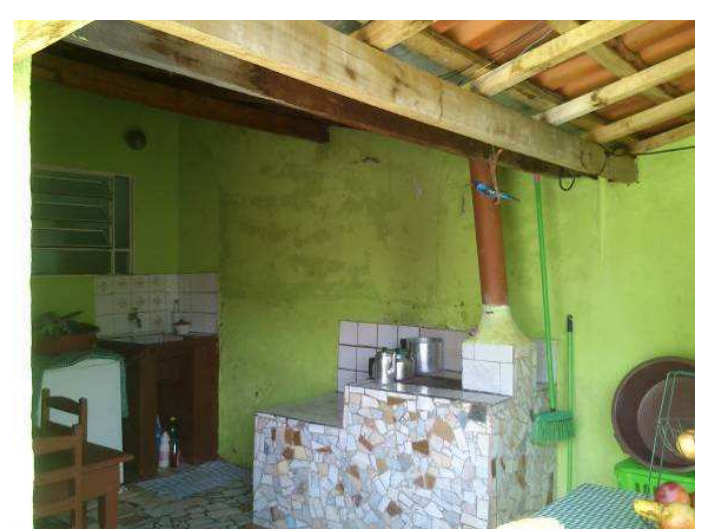

Figura 92 - Área de serviço e varanda com forno a lenha na CNH09 Fonte: a autora.

A realização destes novos cômodos e coberturas para garagens, varandas, áreas de serviço e lazer muitas vezes acabou por afetar a iluminação dos ambientes. Assim, a grande maioria das casas teve a iluminação classificada como inadequada, sendo que a ventilação foi considerada inadequada apenas em uma das residências visitadas, como indicam os gráficos 36 e 37 a seguir: 


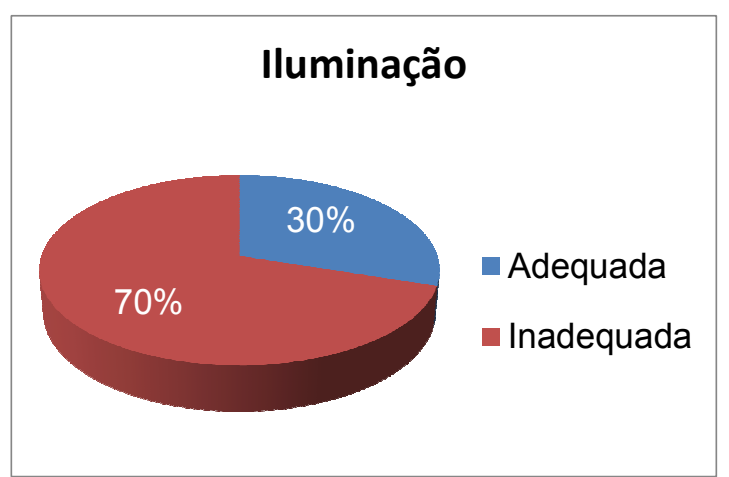

Gráfico 36 - Estudo de Caso 2: Avaliação

técnica da iluminação

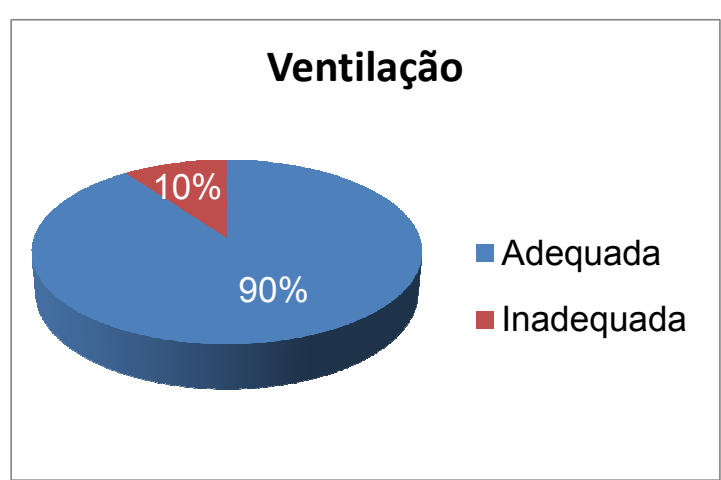

Gráfico 37 - Estudo de Caso 2: Avaliação técnica da ventilação

Em todas as casas foram mantidas as portas e janelas de aço e todas apresentam boas condições. Nos cômodos novos, todas as janelas instaladas são de aço e as portas são de aço ou madeira, todas em bom estado de conservação.

Todas as casas apresentam pintura interna e externa. As paredes novas receberam chapisco e reboco antes da execução da pintura, mas em algumas casas foi feito revestimento apenas na face interna dessas paredes e as faces externas receberam apenas chapisco ou estão totalmente expostas.
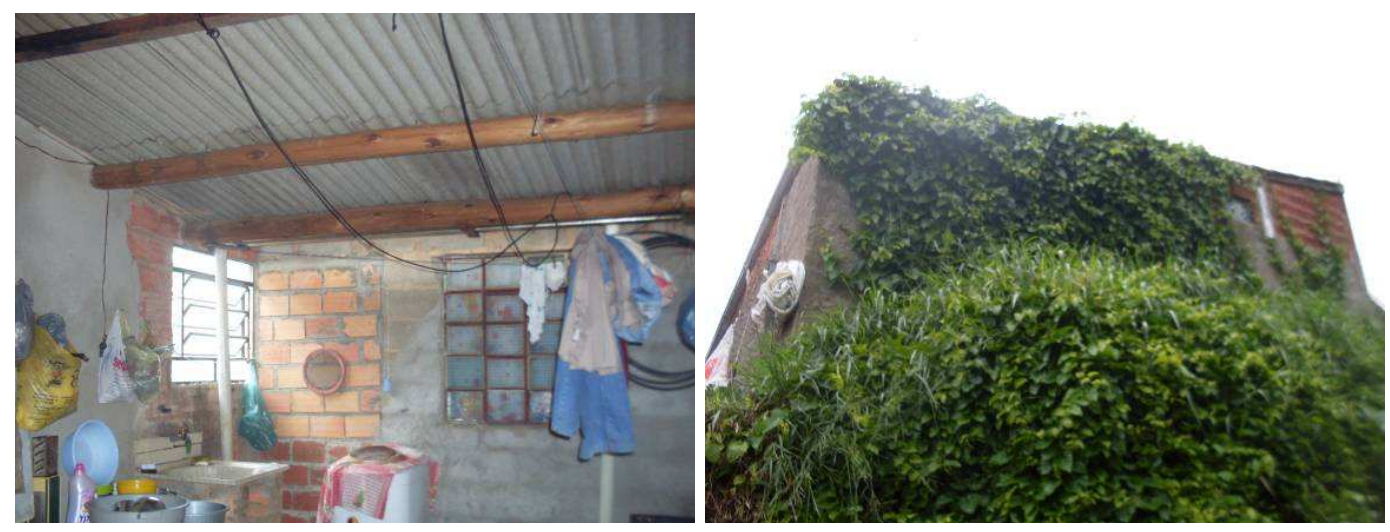

Figura 93 - Face externa de alvenarias sem revestimento na $\mathrm{CNH03}$ e $\mathrm{CNH05}$ Fonte: a autora.

Todos os banheiros receberam azulejos, alguns na parede inteira e outros apenas em meia altura. Apenas uma casa tem azulejo em toda a cozinha e as demais têm duas ou três fiadas de azulejos sobre a pia da cozinha.

Todas as casas têm piso cerâmico no seu interior, sendo que em algumas delas a área de serviço tem piso cimentado. Na casa $\mathrm{CNH09}$, o piso é feito de cacos de cerâmica, também chamado mosaico cerâmico, que segundo a moradora é mais barato. Todos os pisos apresentam boas condições. 
De maneira geral, as instalações elétricas e hidráulicas apresentam boas condições, mas a moradora da casa $\mathrm{CNH01}$ reclama que a tubulação hidráulica apresenta entupimentos frequentes. Já a moradora da casa $\mathrm{CNH02}$ afirma ter problemas frequentes com a instalação elétrica, tais como queima da resistência do chuveiro e queima de aparelhos elétricos, o que indica uma possível sobrecarga.

Os moradores da casa CNH09 também relatam ter tido muitos problemas com as instalações, tanto elétrica quanto hidráulica. Segundo eles, a tubulação hidráulica tinha um diâmetro muito pequeno e entupia muito. Já a instalação elétrica gerava a queima da resistência do chuveiro e de aparelhos elétricos. Para sanar esses problemas, os moradores acabaram por refazer completamente as duas instalações, o que exigiu que muitas das paredes de concreto fossem quebradas.

A moradora da casa $\mathrm{CNHO4}$ reclama que a tubulação do esgoto do vizinho está vazando e o muro do corredor dela está com infiltração e mau cheiro (figura 94).

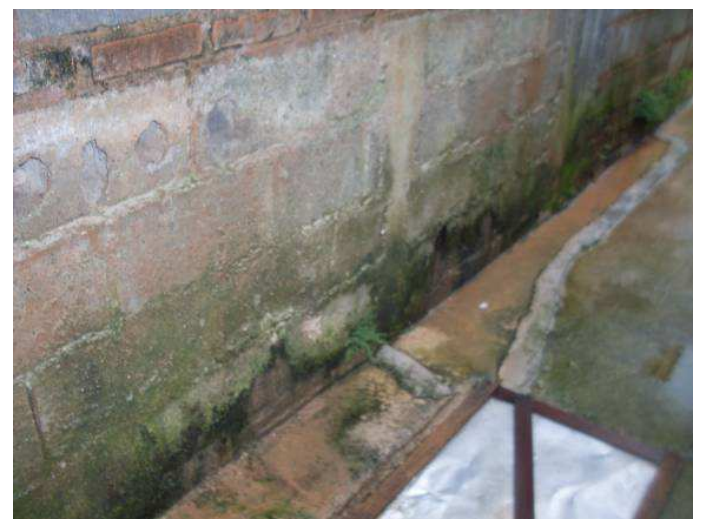

Figura 94 - Muro do corredor da CNH04 com infiltração

Fonte: a autora.

$\mathrm{Na}$ maioria das residências, as modificações realizadas pelos moradores foram consideradas boas, como indica o gráfico 38 :

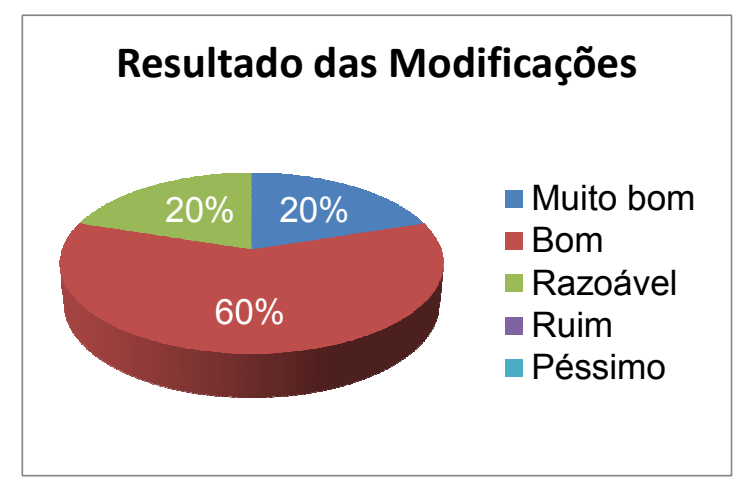

Gráfico 38 - Estudo de Caso 2: Avaliação das modificações realizadas 


\section{O CASO DE LAGOINHA}

Para a realização deste estudo de caso, foi escolhido o Conjunto Habitacional Lagoinha "A", localizado na região central do município de Lagoinha.

O empreendimento é formado por 34 casas geminadas e o seu diferencial é o fato de terem sido utilizados três sistemas construtivos diferentes para execução da mesma tipologia de unidades habitacionais, a saber: alvenaria estrutural com blocos de concreto, paredes de concreto celular moldadas in loco com fôrmas removíveis e estrutura metálica com vedação em blocos de concreto.

\subsection{O Empreendimento}

\subsubsection{Cenário}

O município de Lagoinha está localizado no Alto Paraíba, na Região do Vale do Paraíba, entre a Serra do Quebra-Cangalha e a Serra do Mar, a uma distância de 190 km da Capital do Estado de São Paulo (EMPLASAGEO, 2012). Faz divisa com os municípios de Guaratinguetá, Aparecida, Roseira, São Luiz do Paraitinga, Cunha e Taubaté (PORTAL LAGOINHA, 2012). Segundo dados da Fundação SEADE (2012), sua extensão territorial é de $255,92 \mathrm{~km}^{2}$, com uma população de 4.833 habitantes em 2012. O clima é seco e temperado e sua topografia é acidentada e montanhosa, com uma altitude mínima de 915 metros, e seu território é cortado pelo rio Paraitinga, afluente mais importante do rio Paraíba do Sul e alguns ribeirões (EMPLASAGEO, 2012; PORTAL LAGOINHA, 2012).

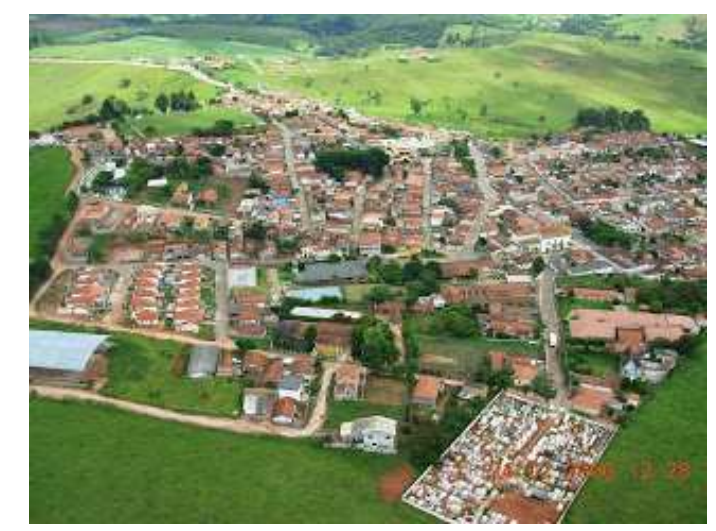

Figura 95 - Vista aérea da cidade de Lagoinha Fonte: PORTAL LAGOINHA, 2012. 
Assim como muitas outras cidades do interior paulista, o município de Lagoinha teve sua origem a partir de uma parada de tropeiros que levavam café do sul de Minas Gerais e Vale do Paraíba para o litoral do Estado, em um local próximo a uma pequena lagoa que veio a inspirar o nome do município. Sua fundação ocorreu devido à doação de terras feita pela família portuguesa Antocas, onde foi construída a Capela de Nossa Senhora da Conceição. Aos poucos o povoado ao seu redor foi se estruturando, sendo oficialmente fundado em 20 de julho de 1803, com o nome de Nossa Senhora da Conceição da Lagoinha. Em 1866 o povoado foi declarado freguesia do município de São Luiz do Paraitinga e em 1880 foi elevado à categoria de vila, recebendo, então, o nome de Lagoinha. Em 1934, no entanto, retornou ao status de distrito, sendo incorporado ao município de Cunha, e em 1944 foi transferido novamente para São Luiz do Paraitinga. Apenas em 1953 conquistou definitivamente a condição de município (EMPLASAGEO, 2012; FUNDAÇÃO SEADE, 2012).

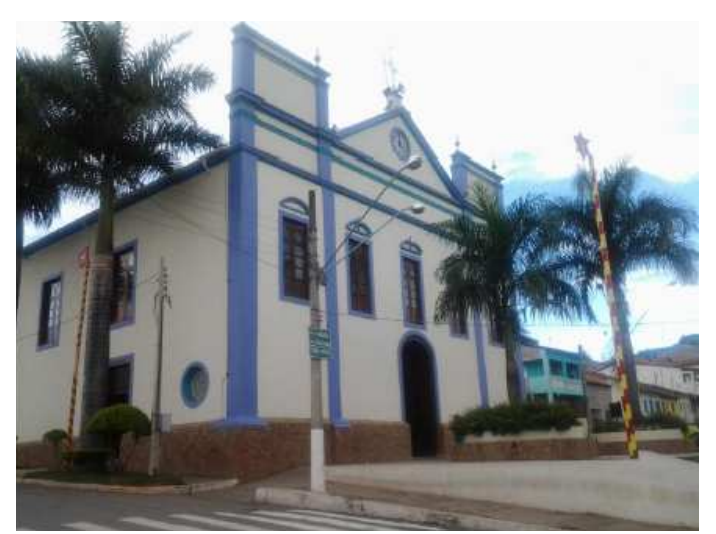

Figura 96 - Igreja Matriz de Lagoinha Fonte: EMPLASAGEO, 2012.

Nas últimas décadas, assim como aconteceu em outros municípios brasileiros, Lagoinha passou por grandes alterações na sua composição populacional devido ao intenso deslocamento da população do campo para a área urbana em busca de estudo e melhores condições de vida e trabalho, sendo que o processo de urbanização do município começou a se intensificar a partir dos anos 70 (PORTAL LAGOINHA, 2012). Segundo dados da Fundação SEADE (2012), em 2010 o município já possuía $64,83 \%$ de sua população vivendo na área urbana e a taxa de crescimento da população no período de 2010 a 2012 ficou negativa em $0,09 \%$ ao ano, o que confirma também o processo de mudança de moradores para cidades maiores, em especial os mais jovens. 
O PIB do município foi de 51,48 milhões em 2010 , sendo que $18,91 \%$ desse valor foi gerado pelo setor primário, 20,55\% pelo setor secundário e $60,53 \%$ pelo setor terciário. No setor primário destacam-se a pecuária, leiteira e de corte, e a criação de aves, equinos e suínos. Já a produção agrícola do município conta com plantações de mandioca, milho, feijão e arroz, porém, em pequena escala devido ao relevo acidentado e técnicas inadequadas de plantio. Por outro lado, a produção hortifrutigranjeira como cenoura, beterraba, couve-flor, pimentão, repolho e outros, vem crescendo. No setor secundário, a cidade conta com cooperativas para pasteurização e comercialização de leite e produção artesanal de queijo, manteiga e requeijão, além de um alambique para produção artesanal de aguardente. O comércio e a prestação de serviços são os maiores responsáveis pela geração de empregos na área urbana e fazem a distribuição dos bens produzidos no município (PORTAL LAGOINHA, 2012).

Por ser considerado um lugar tranquilo e pacífico, sem poluição e com atrativos naturais, Lagoinha tem vocação para o turismo ecológico, rural e de aventura, no entanto, este ainda é pouco explorado. Seu principal atrativo é a Cachoeira Grande, que possui uma queda de $30 \mathrm{~m}$ e é considerada uma das belezas naturais do Vale do Paraíba, sendo muito frequentada no verão por turistas de diversas regiões (PORTAL LAGOINHA, 2012).

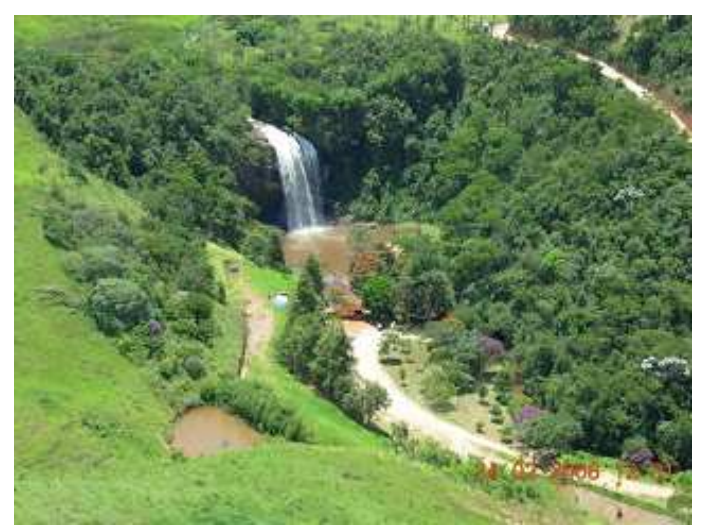

Figura 97 - Vista aérea da Cachoeira Grande Fonte: Portal LAGOINHA, 2012.

Apesar da sua topografia acidentada, o município não apresenta áreas de risco povoadas. Dados da Fundação SEADE (2012) indicam que no ano 2000 cerca de $8 \%$ dos domicílios do município não tinham espaço suficiente. Além disso, o processo de migração da população para a cidade causou um déficit habitacional 
urbano. Visando fornecer melhores condições de habitação para a população, a CDHU implantou, no ano de 2002, o Conjunto Habitacional Lagoinha "A" na região central do município, escolhido como objeto deste estudo de caso.

\subsubsection{Descrição e histórico}

O Conjunto Habitacional Lagoinha "A" está integrado à malha urbana da cidade, no limite sul da região central do município, ao lado do Ginásio Municipal e a cerca de 300 metros do centro da cidade. O acesso se faz pela Avenida Coronel Manoel Antônio Domingues Castro e pela Rua Padre Valério Cardoso.

A gleba apresenta declividade moderada na região das unidades habitacionais, não ultrapassando os 15\%, e não há terrenos alagadiços e sujeitos a inundação. Ao sul das residências há uma área destinada a lazer, porém este espaço nunca foi provido de equipamentos para este fim, estando desocupada até o momento. A oeste encontra-se o ginásio municipal, ao norte a Escola Estadual Padre Chico. A figura 98, a seguir, apresenta a implantação do conjunto habitacional:

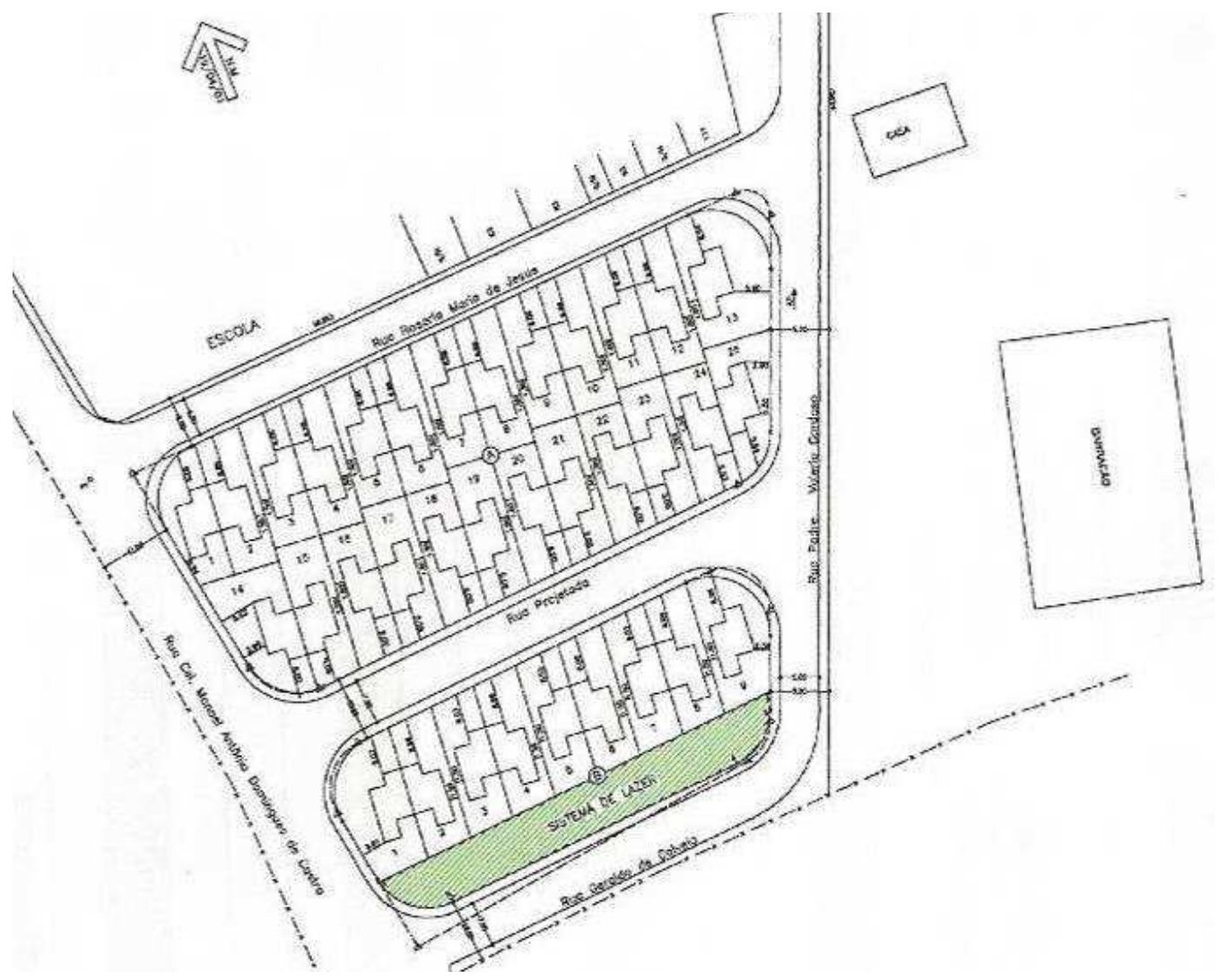

Figura 98 - Implantação do Conjunto Habitacional Lagoinha "A"

Fonte: SILVA, 2012. 


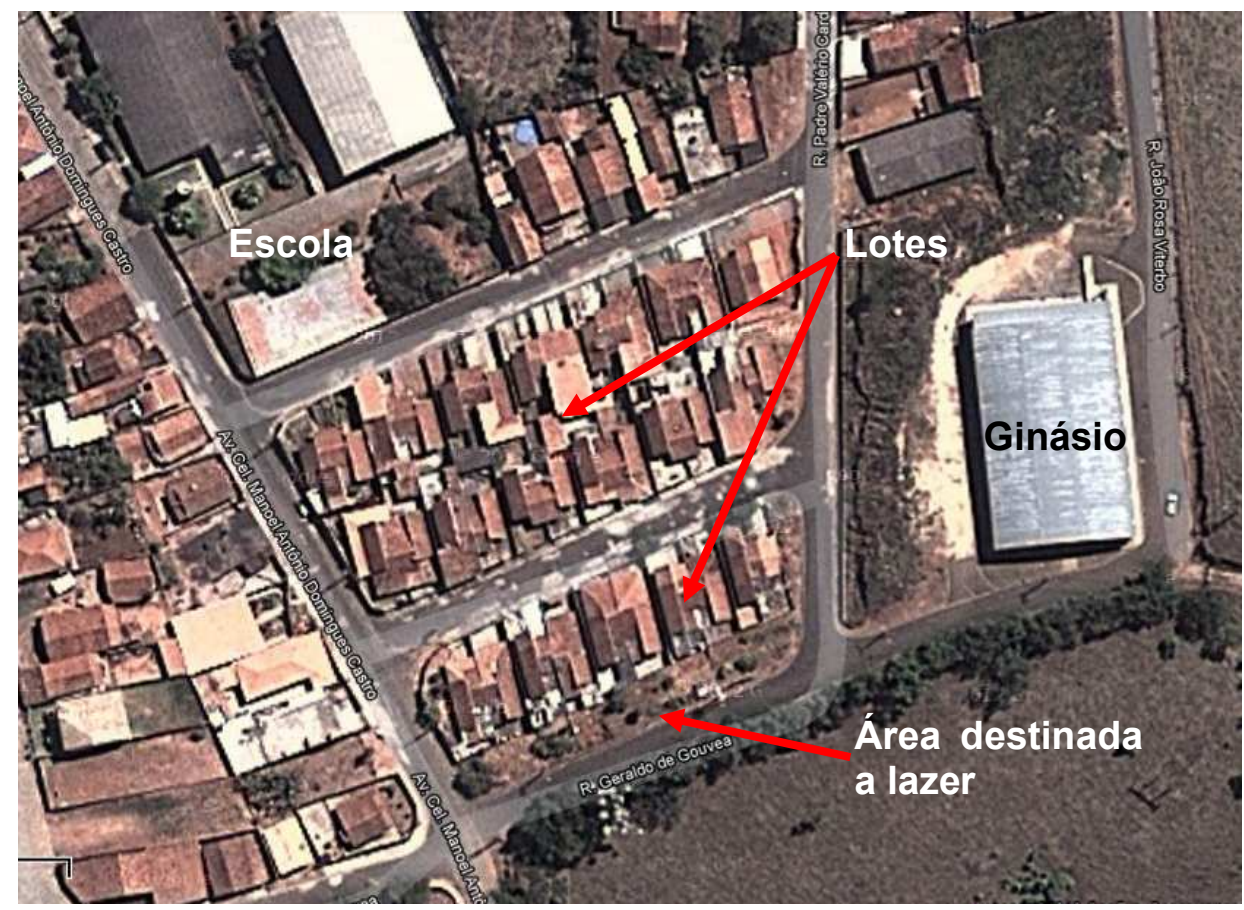

Figura 99 - Vista geral do Conjunto Habitacional Lagoinha "A" Fonte: GOOGLE MAPS.

As ruas possuem pavimento asfáltico e as calçadas são cimentadas. $O$ conjunto habitacional conta, ainda, com iluminação das vias púbicas através de postes com fiação aérea, rede de abastecimento de água, rede de coleta de esgotos, rede de captação de águas pluviais e serviço de coleta de lixo.
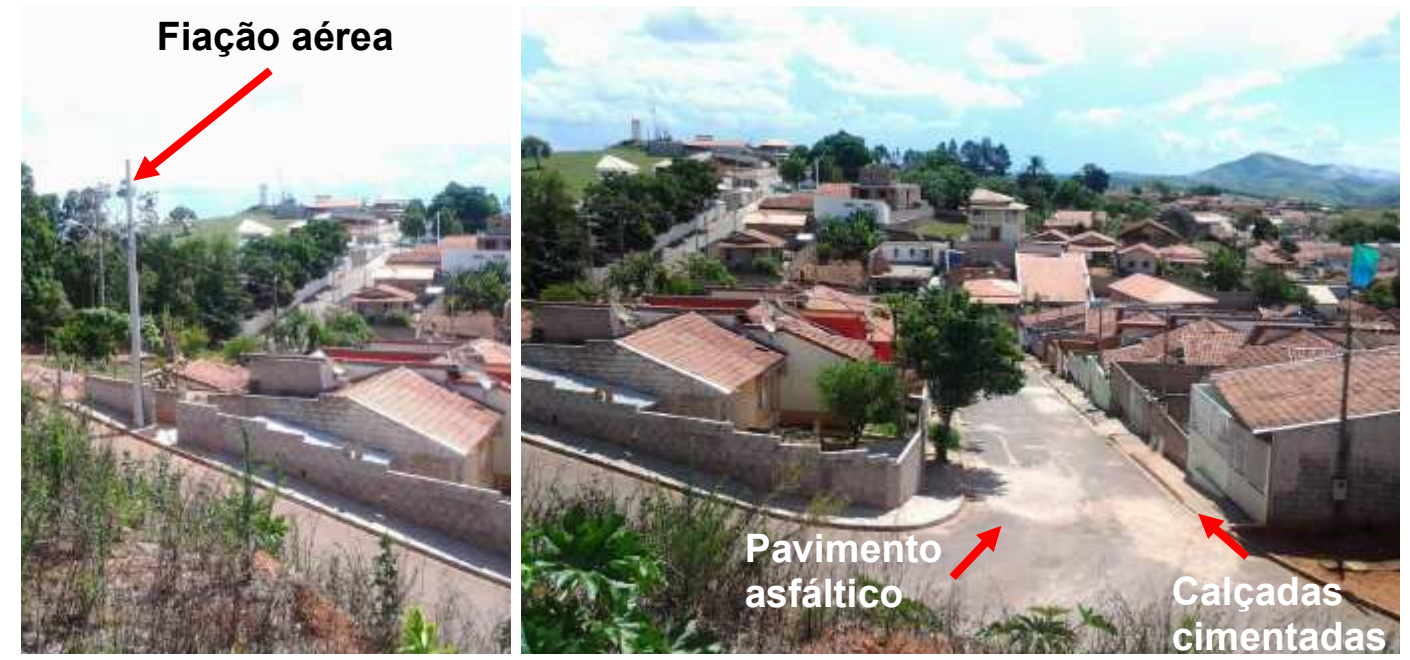

Figura 100 - Vista geral do Conjunto Habitacional Lagoinha "A" Fonte: EMPLASAGEO, 2012. 
O Conjunto Habitacional Lagoinha "A" é composto por 34 unidades habitacionais térreas e geminadas duas a duas, atendendo à tipologia TG23A da CDHU na versão de 2 dormitórios com possibilidade de execução de mais um. Cada unidade tem $42,71 \mathrm{~m}^{2}$ de área construída e conta com sala, cozinha, dois dormitórios e um banheiro dispostos em um lote de aproximadamente $160 \mathrm{~m}^{2}(8 \mathrm{~m} \times 20 \mathrm{~m}) \mathrm{de}$ área (SILVA, 2012), sendo que os lotes das extremidades são um pouco maiores.

Para a execução das casas, foram utilizados três sistemas construtivos diferentes a título de experiência. Das 34 unidades construídas, 30 foram executadas pelo processo de alvenaria estrutural com blocos de concreto, 2 pelo processo de paredes de concreto moldadas in loco e duas pelo processo de estruturas metálicas com vedação em blocos de concreto.

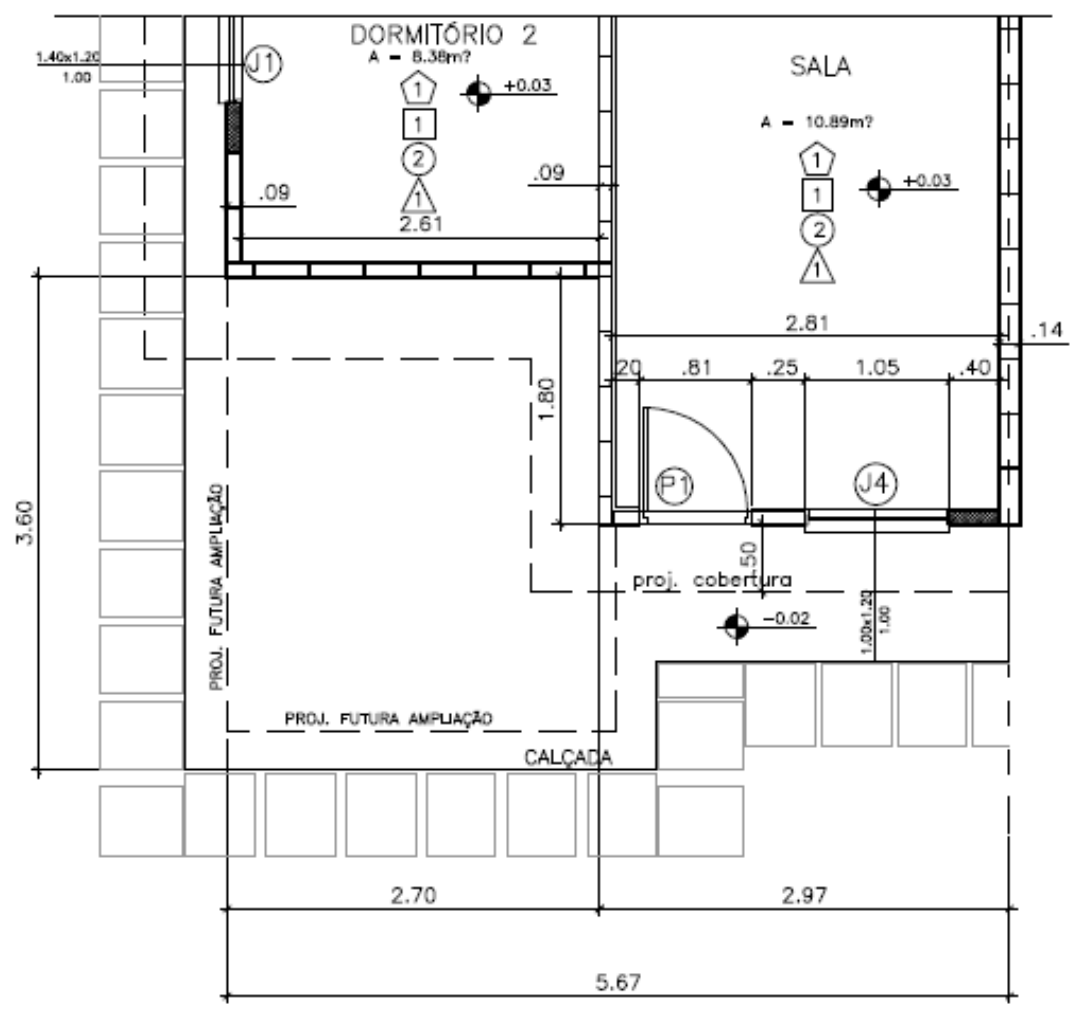

Figura 101 - Detalhe da tipologia TG23A na fase inicial com 2 dormitórios Fonte: CDHU. 


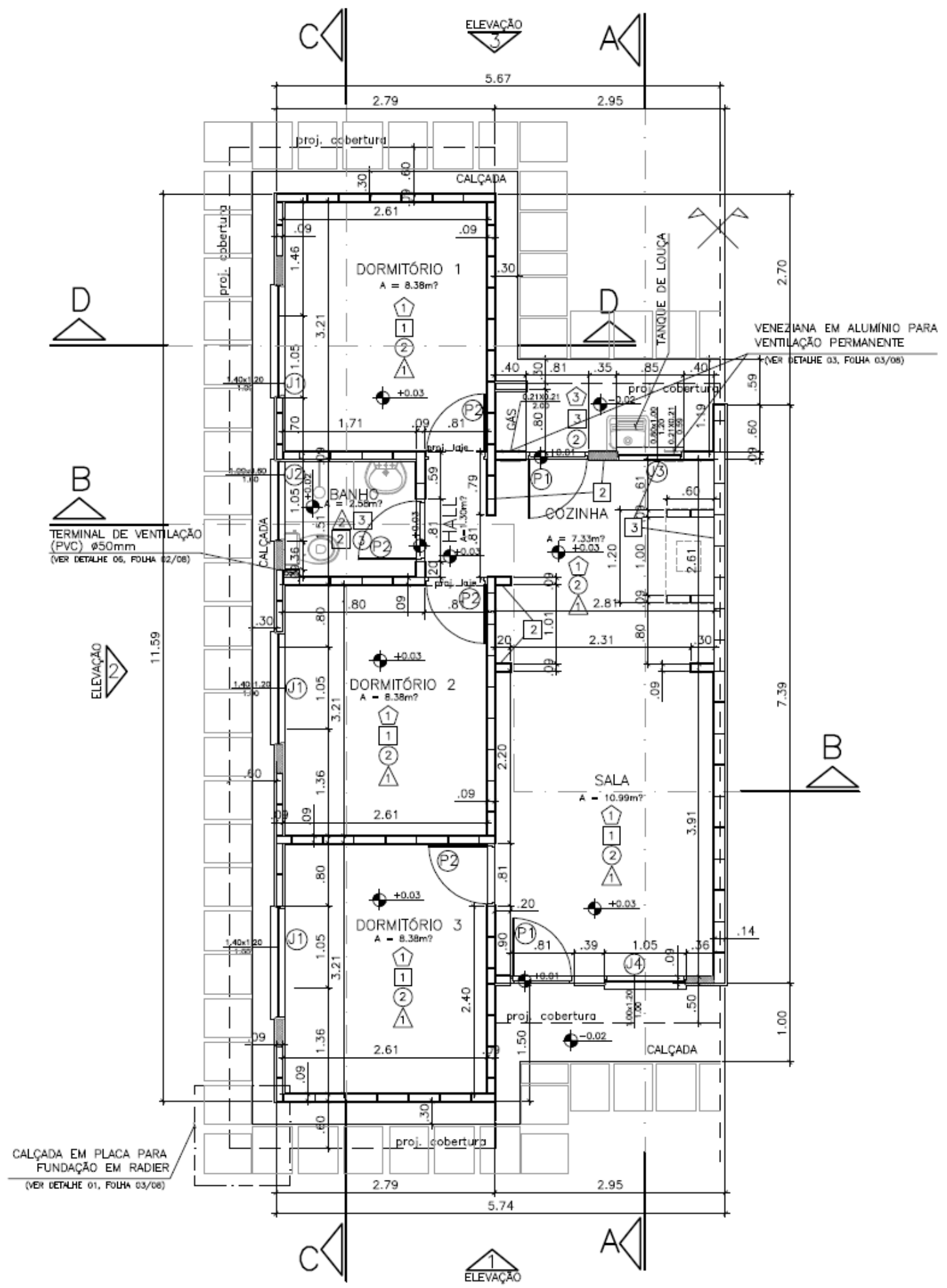

Figura 102 - Tipologia TG23A em alvenaria estrutural, com 3 dormitórios

Fonte: CDHU. 


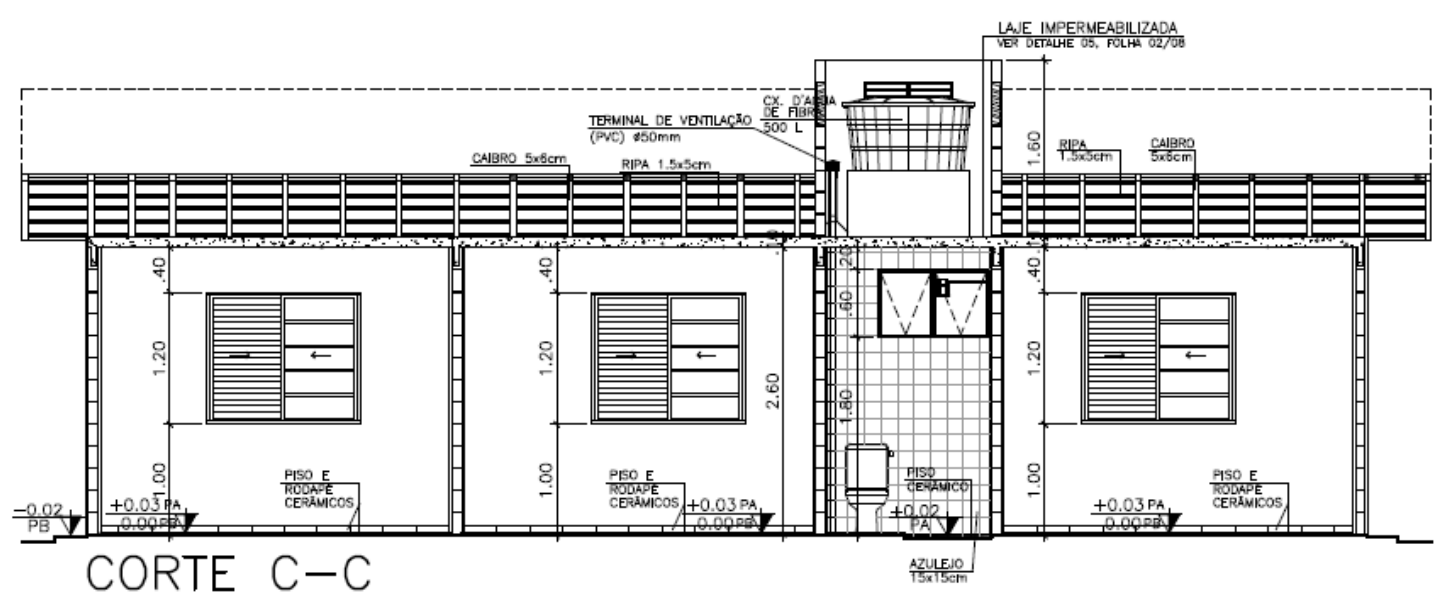

Figura 103 - Corte CC da tipologia TG23A

Fonte: CDHU.

Antes do início da construção foi realizado o serviço de adequação do projeto padrão da CDHU para os sistemas construtivos de paredes de concreto celular moldadas in loco e estruturas metálicas CSN com vedação em blocos de concreto.

Assim como no estudo de caso anterior, as casas foram construídas em regime de mutirão e, no intuito de reduzir os custos, os blocos de concreto foram fabricados no canteiro pelos próprios mutirantes. O tempo de execução das casas foi excelente, sendo finalizadas num período de 12 meses, com o mutirão trabalhando de segunda a sexta-feira, das $7 \mathrm{~h}$ às $17 \mathrm{~h}$, sendo que as mulheres representaram o número maior de mutirantes (SILVA, 2012).

Ainda seguindo a metodologia do mutirão, as famílias que tiveram mais horas de trabalho ganharam itens de acabamento a mais do que as demais e tiveram a chance de escolher primeiro suas casas.

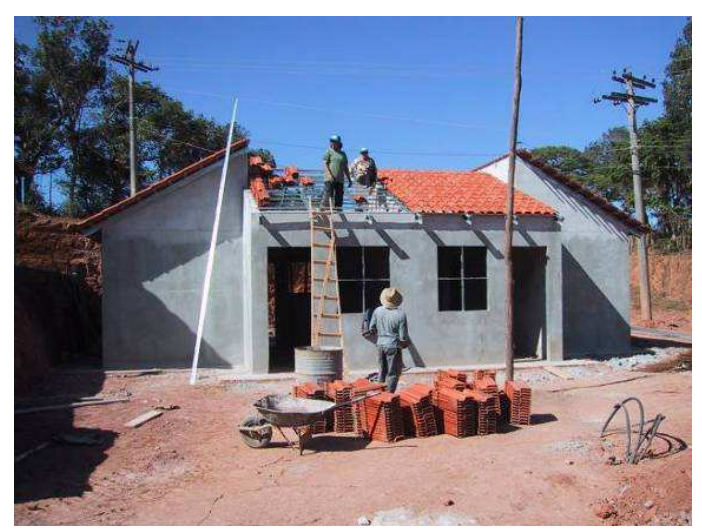

Figura 104 - Fotos da execução das obras em Lagoinha Fonte: acervo ABCP. 
As casas foram construídas sob supervisão de uma empresa gerenciadora, que manteve um mestre de obras e um encarregado em tempo integral no canteiro para orientar os mutirantes, além do acompanhamento de um engenheiro. A ABCP foi convidada a acompanhar a construção das casas em paredes de concreto celular moldadas in loco, viabilizadas e construídas pela empresa Tecnometa, fornecedora do aditivo para execução do concreto aerado ${ }^{9}$. Ao acompanhar a execução dessas casas, porém, os profissionais da ABCP tiveram também a oportunidade de observar a construção das demais unidades deste conjunto habitacional.

Não há informações sobre patologias identificadas nas casas de alvenaria estrutural ainda na fase de execução. No caso das casas em paredes de concreto celular moldadas in $10 c o$, verificou-se que o concreto não atingiu a plasticidade necessária e surgiu uma série de "bicheiras", que foram corrigidas antes da entrega e não comprometeram as unidades ${ }^{10}$. As casas de estrutura metálica foram entregues com a estrutura e a laje prontas e coube aos mutirantes a execução da alvenaria de vedação, instalações e acabamentos.

As 34 unidades habitacionais do Conjunto Habitacional Lagoinha " $A$ " foram entregues em 2002 sem o acabamento. A tabela a seguir apresenta uma descrição das casas entregues baseada nos 10 órgãos básicos do edifício apresentados por Roméro e Ornstein (2003):

\footnotetext{
${ }^{9}$ Informação fornecida pelo Arq $^{\circ}$ Carlos Chaves em entrevista por e-mail em 24/01/2013.

${ }^{10}$ Informação fornecida pelo Arq $^{\circ}$ Carlos Chaves em entrevista por e-mail em 24/01/2013.
} 
Tabela 5 - Descrição das unidades habitacionais do Conjunto Lagoinha "A"

\begin{tabular}{|c|l|}
\hline $\begin{array}{c}\text { Órgão do } \\
\text { Edifício }\end{array}$ & \multicolumn{1}{|c|}{ Descrição } \\
\hline Terrapleno & $\begin{array}{l}\text { Os lotes foram entregues sem muros, com exceção das divisas de lotes } \\
\text { que tinham um desnível no terreno, onde foram feitos pequenos muros } \\
\text { de contenção apenas até o nível do lote mais alto. Os lotes foram } \\
\text { entregues com grama e um caminho formado de placas de concreto do } \\
\text { limite frontal do lote até a entrada das unidades habitacionais. }\end{array}$ \\
\hline Fundação & A fundação adotada é do tipo radier. \\
\hline Estrutura & $\begin{array}{l}\text { Alvenaria estrutural com blocos de concreto (30 U.H.), paredes de } \\
\text { concreto celular moldadas in loco (2 U.H.) e estrutura metálica CSN (2 } \\
\text { U.H.). Laje maciça de concreto na casa toda. }\end{array}$ \\
\hline Cobertura & Estrutura metálica e telhas cerâmicas tipo romana. \\
\hline Vedações & $\begin{array}{l}\text { Alvenaria estrutural com blocos de concreto (30 U.H.), paredes de } \\
\text { concreto celular moldadas in loco (2 U.H.) e blocos de concreto (2 U.H.). }\end{array}$ \\
\hline Esquadrias & Portas e janelas de aço com pintura em esmalte e vidros. \\
\hline Paramentos & $\begin{array}{l}\text { Chapisco e reboco nas alvenarias. Pintura externa com textura acrílica } \\
\text { hidrorrepelente e interna com látex PVA sobre massa corrida. }\end{array}$ \\
\hline Pisos & $\begin{array}{l}\text { As casas foram entregues apenas com o piso cimentado. } \\
\text { Instalação elétrica e hidráulica convencional, com eletrodutos plásticos, } \\
\text { tubulação de PVC e fiação de cobre encapada. Todas as instalações } \\
\text { foram embutidas nas paredes. }\end{array}$ \\
\hline
\end{tabular}

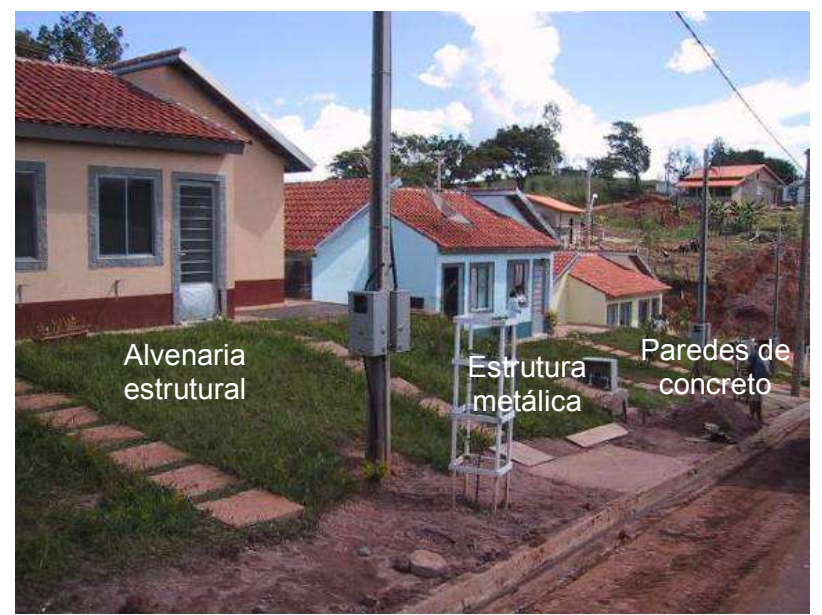

Figura 105 - Casas nos três sistemas construtivos entregues em Lagoinha Fonte: acervo $A B C P$. 


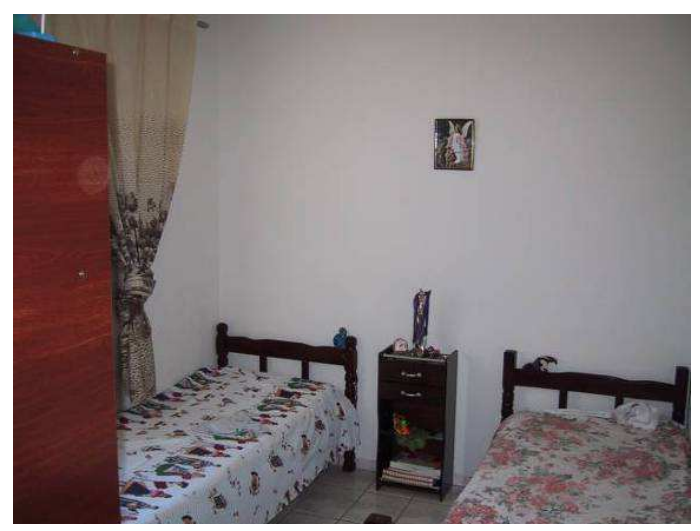

Figura 106 - Interior de uma das casas logo após a entrega Fonte: acervo ABCP.

\subsubsection{Sistema Construtivo: Alvenaria estrutural com blocos de concreto}

O principal processo construtivo utilizado no Conjunto Habitacional Lagoinha "A" é a Alvenaria Estrutural com Blocos de Concreto, mas também foram adotados, em caráter de experiência, os processos de paredes de concreto celular moldadas in loco e o sistema de estruturas metálicas com vedações em blocos de concreto.

Neste estudo de caso, será analisado com mais ênfase o processo de alvenaria estrutural com blocos de concreto, uma vez que o processo de paredes de concreto celular moldadas in loco já foi analisado no caso anterior. Há de se ressaltar, porém, que, o sistema utilizado nas casas de Lagoinha utilizou fôrmas plásticas e a estrutura dos telhados é metálica.

Já o processo de estruturas metálicas com vedações em blocos de concreto apresenta apenas dois exemplares para estudo, uma amostra considerada insuficiente para se chegar a conclusões com a precisão exigida nesta pesquisa.

Assim, será detalhado, a partir de agora, o sistema de alvenaria estrutural com blocos de concreto utilizado neste empreendimento.

\subsubsection{Materiais}

Para que a alvenaria estrutural cumpra as funções desejadas de desempenho estrutural, conforto termo-acústico, vedação e durabilidade, é fundamental que os materiais sejam especificados corretamente e a execução seja bem feita.

Em relação aos materiais, os principais componentes da alvenaria estrutural são: os blocos estruturais de concreto, a argamassa de assentamento e o graute. 


\section{Blocos de Concreto}

Segundo Salvador Filho (2007), os blocos de concreto são constituídos de cimento Portland, agregados graúdo e miúdo e água, podendo, em função de necessidades específicas, ter a adição de outros componentes, como adições minerais, pigmentos, aditivos etc. Assim, esses componentes devem ser especificados e utilizados de acordo com suas propriedades específicas para que o produto final atenda às características especificadas.

Ainda de acordo com Salvador Filho (2007), o processo de fabricação é feito através de vibro-prensagem, com máquinas capazes de produzir milhares de blocos por dia e com controles automáticos para regular altura e densidade do bloco, controlar matérias-primas, pesagem, mistura, colocação dos paletes e retirada do bloco recém-moldados. O autor salienta, ainda, que o concreto utilizado para a fabricação dos blocos deve ter consistência seca para permitir que estes sejam desmoldados rapidamente após a compactação sem que sofram variações dimensionais durante as operações de transporte, cura etc.

Prudêncio Jr. et al. (2003) ressaltam que a fabricação, cura e manipulação dos blocos devem utilizar processos que garantam um concreto suficientemente homogêneo e compacto.

A NBR 6136 (ABNT, 2007) classifica os blocos vazados de concreto em:

- Classe A (fbk > $6 \mathrm{MPa}$ ): Com função estrutural, para uso em elementos de alvenaria acima ou abaixo do nível do solo.

- Classe B (fbk > $4 \mathrm{MPa}$ ): Com função estrutural, para uso em elementos acima do nível do solo.

- Classe C (fbk > $3 \mathrm{MPa}$ ): Com função estrutural, para uso em elementos acima do nível do solo.

- Classe D (fbk > $2 \mathrm{MPa}$ ): Sem função estrutural, para uso em elementos de alvenaria acima do nível do solo.

Esses elementos são separados no que chamamos de "família de blocos", que é o conjunto de componentes de alvenaria que interagem modularmente entre si e com outros elementos construtivos (COMUNIDADE DA CONSTRUÇÃO, 2012). De acordo com a NBR 6136 (ABNT, 2007), os blocos que compõem uma família, segundo suas dimensões, são designados como: bloco inteiro (bloco predominante), 
meio bloco, blocos de amarração L e T (blocos para encontros de paredes), blocos compensadores A e B (blocos para ajustes de modulação) e blocos tipo canaleta.

Duas famílias de blocos de concreto são utilizadas no Brasil, a família 29 e a família 39, apresentadas na tabela 6 , a seguir:

Tabela 6 - Comparativo entre as famílias de blocos de concreto
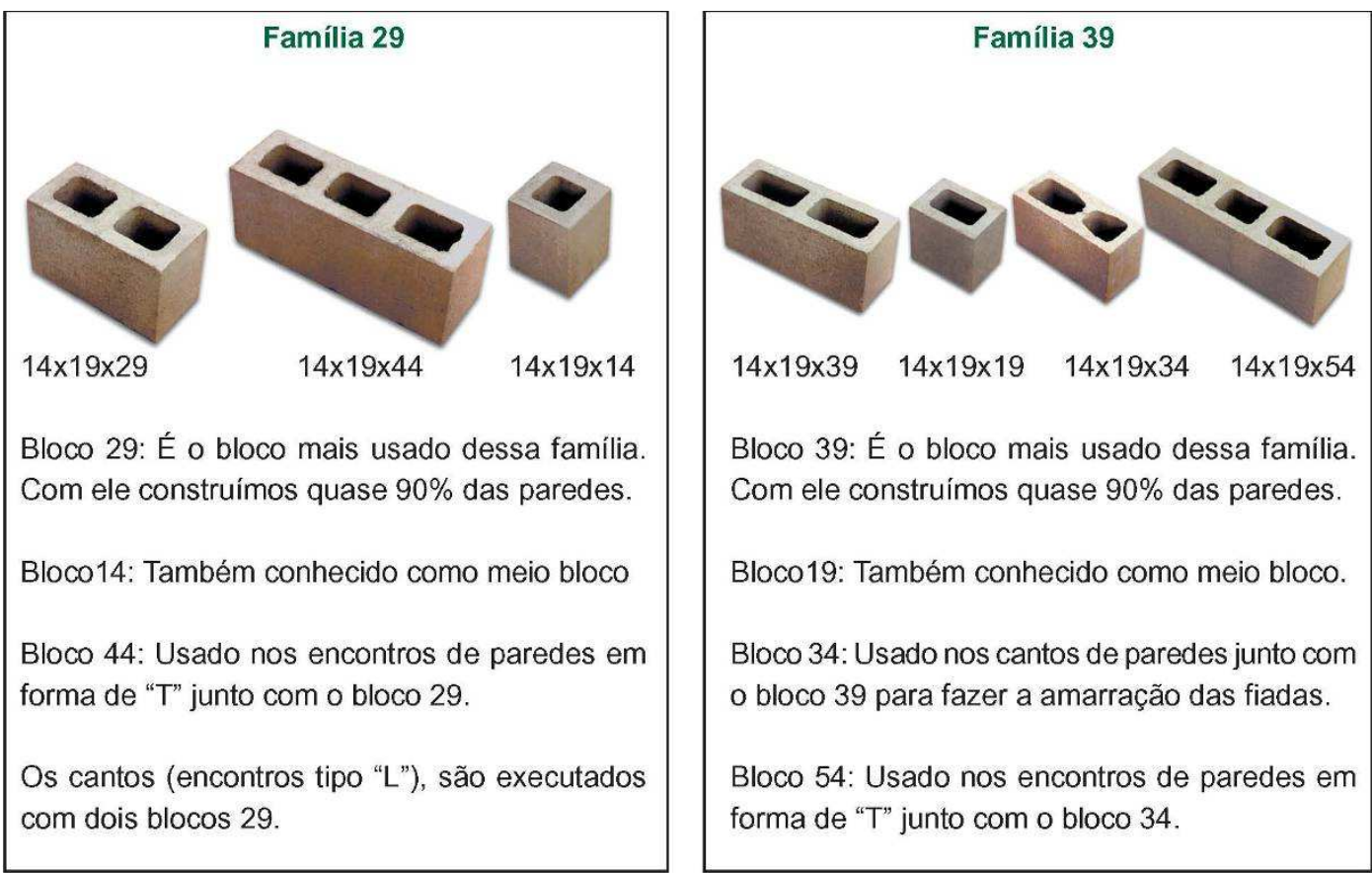

Blocos Especiais: blocos tipo canaleta e tipo "J".

São utilizados na construção das cintas, vergas e contra-vergas

Fonte: COMUNIDADE DA CONSTRUÇÃO, 2012.

As dimensões reais dos blocos vazados de concreto, modulares e submodulares, devem corresponder às dimensões constantes da tabela 7 a seguir: 
Tabela 7 - Famílias de blocos

\begin{tabular}{|c|c|c|c|c|c|c|c|c|c|c|c|}
\hline \multirow{4}{*}{ 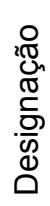 } & \multirow{3}{*}{\begin{tabular}{|l|} 
Nominal \\
Módulo \\
Amarração
\end{tabular}} & \multirow{3}{*}{$\frac{20}{\frac{M-20}{1 / 2}}$} & \multicolumn{2}{|c|}{15} & \multicolumn{3}{|c|}{12,5} & \multicolumn{3}{|c|}{10} & 7,5 \\
\hline & & & \multicolumn{2}{|c|}{ M-15 } & \multicolumn{3}{|c|}{$M-12,5$} & \multicolumn{3}{|c|}{$M-10$} & $M-7,5$ \\
\hline & & & $1 / 2$ & $1 / 2$ & $1 / 2$ & $1 / 2$ & $1 / 3$ & $1 / 2$ & $1 / 2$ & $1 / 3$ & $1 / 2$ \\
\hline & Linha & $20 \times 40$ & $15 \times 40$ & $15 \times 30$ & $12,5 \times 40$ & $12,5 \times 25$ & $12,5 \times 37,5$ & $10 \times 40$ & $10 \times 30$ & $10 \times 30$ & $7,5 \times 40$ \\
\hline \multicolumn{2}{|c|}{ Largura $(\mathrm{mm})$} & 190 & 140 & 140 & 115 & 115 & 115 & 90 & 90 & 90 & 65 \\
\hline \multicolumn{2}{|r|}{ Altura (mm) } & 190 & 190 & 190 & 190 & 190 & 190 & 190 & 190 & 190 & 190 \\
\hline \multirow{8}{*}{ 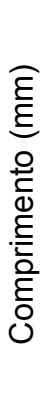 } & Inteiro & 390 & 390 & 290 & 390 & 240 & 365 & 390 & 190 & 290 & 390 \\
\hline & Meio & 190 & 190 & 140 & 190 & 115 & - & 190 & 90 & - & 190 \\
\hline & $2 / 3$ & - & - & - & - & - & 240 & - & - & 190 & - \\
\hline & $1 / 3$ & - & - & - & - & - & 115 & - & - & 90 & - \\
\hline & Amarração L & - & 340 & - & - & - & - & - & - & - & - \\
\hline & Amarração T & - & 540 & 440 & - & 365 & 365 & - & 290 & 290 & - \\
\hline & Compensador A & 90 & 90 & - & 90 & - & - & 90 & - & - & 90 \\
\hline & Compensador B & 40 & 40 & - & 40 & - & - & 40 & - & - & 40 \\
\hline
\end{tabular}

Fonte: NBR 6136 (ABNT, 2007).

Segundo Parsekian (2012), a espessura mínima para uma parede estrutural é de $14 \mathrm{~cm}$, sendo possível uma flexibilização para edificações com até dois pavimentos. Nesse caso, o índice de esbeltez $(L)$, que é a relação entre a altura efetiva (hef) e a espessura efetiva (hef), para o caso de alvenaria não armada deve respeitar os seguintes limites:

- $\quad\left(h_{\mathrm{ef}} / \mathrm{t}_{\mathrm{ef}}\right) \leq 24$ para alvenaria não armada;

- $\left(\mathrm{h}_{\mathrm{ef}} / \mathrm{t}_{\mathrm{ef}}\right) \leq 30$ para alvenaria armada.

Já a Comunidade da Construção (2012) recomenda que os blocos com função estrutural classe C sejam empregados, conforme sua designação, da seguinte forma:

- Blocos M10 - edificações de no máximo 1 pavimento

- Blocos M12,5 - edificações de no máximo 2 pavimentos

- Blocos M15 e M20 - edificações maiores

De acordo com Prudêncio Jr. et al. (2003), os blocos devem ter arestas vivas e não devem apresentar trincas, fraturas ou outros defeitos que possam prejudicar o seu assentamento ou afetar a resistência e durabilidade da construção, não sendo permitida qualquer pintura que oculte defeitos eventualmente existentes no bloco. Os autores alertam, ainda, que a textura do bloco deve apresentar rugosidade e porosidade superficial adequadas para que haja aderência com a argamassa, tornando o conjunto monolítico. 
Para obter o máximo de vantagens oferecidas pelo sistema, é imprescindível que os blocos de concreto tenham precisão e estabilidade dimensional. Para tanto, os blocos devem ser fabricados com as dimensões corretas e a retração por secagem, que é a redução do volume decorrente da evaporação da água excedente do concreto, deve ser sempre inferior a 0,065 \% (PRUDÊNCIO JR. et al., 2003). A NBR 6136 (ABNT, 2007) determina a tolerância máxima de 2,0 mm para a largura e 3,0 $\mathrm{mm}$ para a altura e comprimento dos blocos.

Os blocos de concreto podem ser produzidos com resistências características (fbk) variadas, de acordo com a necessidade estrutural da edificação. Os blocos mais utilizados são aqueles com fbk entre 4,0 e 12,0 MPa, mas é possível encontrar no mercado fabricantes que produzem blocos de até $25 \mathrm{MPa}$. O projetista é o responsável por determinar a resistência característica à compressão dos blocos (fbk), sendo que podem ser determinadas resistências diferentes em uma mesma edificação.

A NBR 6136 (ABNT, 2007) determina que a absorção dos blocos de concreto deve ser inferior a $10 \%$ quando utilizado agregado normal, sendo que quanto mais denso o bloco, menor será a sua absorção. Valores superiores a este indicam blocos porosos, com baixa resistência mecânica e tendência a absorver rapidamente a água da argamassa de assentamento das alvenarias. Por outro lado, blocos com absorção muito baixa (próxima a zero) praticamente não absorvem água da argamassa, prejudicando a aderência da argamassa ao bloco e, consequentemente, o enrijecimento das juntas. Uma absorção em torno de $6 \%$ é bastante adequada (PRUDÊNCIO JR. et al., 2003).

\section{Argamassa de Assentamento}

Segundo Prudêncio Jr. et al. (2003), "a argamassa é prioritariamente um adesivo que une as unidades de alvenaria e que serve para transferir esforços entre elas, bem como para acomodar pequenas deformações inerentes à própria alvenaria".

Em uma parede de alvenaria, as juntas de argamassa têm as funções de unir solidariamente os blocos e ajudá-los a resistir aos esforços laterais, distribuir uniformemente as cargas por toda a área resistente dos blocos, absorver as 
deformações naturais a que a alvenaria estiver sujeita e selar as juntas contra a penetração de água (SABBATINI, 1984 apud PRUDÊNCIO JR. et al. 2003).

É incorreto pensar que a boa argamassa é aquela que atende aos mesmos requisitos de um bom concreto, pois, diferentemente do concreto, a resistência à compressão é secundária para a argamassa. Como a argamassa trabalha absorvendo deformações, não pode ser muito rígida e, por ser assentada sobre superfícies absorventes, é importante sua capacidade de retenção de água (PRUDÊNCIO JR. et al., 2003).

Ainda de acordo com Prudêncio Jr. et al. (2003), a argamassa de assentamento utilizada na alvenaria estrutural deve apresentar as seguintes propriedades:

- No estado fresco

- trabalhabilidade suficiente para uma boa produção;

- capacidade de retenção de água para não ser alterada em caso de elevada sucção;

- adquirir rapidamente a resistência para resistir aos esforços de construção.

- No estado endurecido

- ter suficiente aderência aos blocos para garantir a resistência e estanqueidade da alvenaria;

○ $\quad$ ter resistência à compressão suficiente para não comprometer a alvenaria, porém, sem nunca ser mais resistente do que os blocos;

○ ter baixo módulo de deformação para acomodar as deformações sem fissurar.

Ainda segundo os autores, essas características são fortemente dependentes da composição da argamassa e das características dos blocos que irão interagir com ela. Dessa forma, é importante a realização de ensaios não só para determinar as características da argamassa, mas também para determinar as características do conjunto.

As argamassas para assentamento de blocos de concreto podem ser industrializadas ou "viradas" na obra. De qualquer forma, os principais componentes da mistura são cimento Portland, cal, areia e água, podendo ser adicionados aditivos específicos para alterar suas propriedades. 
Seja qual for o tipo de argamassa utilizada, não é recomendado o preparo em betoneiras comuns. O ideal é que a mistura seja realizada em misturadores específicos para esse fim, as argamassadeiras, que dão maior homogeneidade à argamassa. Quanto à sua aplicação, de modo geral, o tempo entre a mistura e o uso da argamassa não deve exceder o prazo de duas horas e meia (COMUNIDADE DA CONSTRUÇÃO, 2012). Todas as argamassas devem atender às especificações das normas pertinentes.

\section{Graute}

O graute é um tipo especial de concreto, definido pela NBR 15961 (ABNT, 2011) como um "componente utilizado para preenchimento de espaços vazios de blocos com a finalidade de solidarizar armaduras à alvenaria ou aumentar sua capacidade resistente". É composto por cimento, areia, pedrisco e água, podendo ser adicionada cal com teor não superior a $10 \%$ do volume do cimento ou outra adição que proporcione trabalhabilidade e retenção de água de hidratação à mistura (ABNT, 2011; COMUNIDADE DA CONSTRUÇÃO, 2012).

O graute influencia decisivamente na resistência à compressão das paredes com vazios preenchidos, sendo inclusive utilizado como recurso dos calculistas para aumentar a capacidade portante da parede sem aumentar a sua espessura. A resistência do graute é definida pelo projetista de estruturas, mas a NBR 15961 (ABNT, 2011) determina uma resistência mínima de $15 \mathrm{MPa}$ para alvenarias estruturais.

É utilizado para preenchimento das canaletas, blocos $\mathrm{J}$ de apoio das lajes, vergas e contravergas de janelas e nos furos verticais, podendo estar ou não acompanhado de armadura (COMUNIDADE DA CONSTRUÇÃO, 2012). Segundo Prudêncio Jr. et al. (2003), o graute deve apresentar uma elevada fluidez para preencher completamente os vazados dos blocos sem deixar espaços vazios.

A NBR 15961 (ABNT, 2011) determina, ainda, que o graute deve ser utilizado dentro do prazo máximo de $2 \mathrm{~h} 30$ min após a adição de água à mistura. $\mathrm{A}$ única exceção à essa regra é no caso de utilização de aditivo retardador de pega, sendo que neste caso, devem ser seguidas as recomendações do fabricante. 


\section{Armaduras}

As barras de aço utilizadas na alvenaria estrutural são as mesmas utilizadas nas estruturas de concreto armado, sendo que devem ser envolvidas pelo graute para que trabalhem em conjunto com o restante da alvenaria. Essas armaduras podem ser utilizadas verticalmente em pontos determinados pelo projetista estrutural e horizontalmente nas canaletas, blocos $\mathrm{J}$, vergas e contravergas. Em edifícios onde não ocorrem tensões de tração devido ao vento, a bitola mais utilizada é a de 10 $\mathrm{mm}$, exceto pelas barras posicionadas nas juntas de argamassa, que devem ter um diâmetro mínimo de $3,8 \mathrm{~mm}$ ou metade da espessura da junta (COMUNIDADE DA CONSTRUÇÃO, 2012).

\section{Prismas de blocos de concreto}

O prisma é um corpo de prova considerado a menor unidade representativa de uma alvenaria e é obtido pela sobreposição de dois blocos unidos por uma junta horizontal de argamassa, podendo ter os vazados ocos ou cheios com graute.

A NBR 15961 (ABNT, 2011) prescreve os métodos de preparo e ensaio de prismas de blocos de concreto para alvenaria estrutural, que devem ser realizados para caracterização prévia da alvenaria e para controle de obras com especificação de resistência característica de bloco inferior a $12 \mathrm{MPa}$.

\subsubsection{O Sistema}

A alvenaria estrutural data de milhares de anos atrás, no entanto, com a utilização de blocos de rochas, com diversos exemplos como as Pirâmides do Egito, a Muralha da China e o Coliseu de Roma. Os blocos de concreto só foram criados e patenteados por Gibbs em 1850 e a alvenaria estrutural propriamente dita, concebida a partir de teorias de cálculo, só surgiu por volta de 1950 (PRUDÊNCIO JR. et al., 2003).

Hoje, a alvenaria estrutural com blocos de concreto conta com diversas normas voltadas à qualidade dos materiais e ao processo construtivo em todo o mundo, sendo que as principais normas brasileiras em vigor são:

- NBR 6136 (2007) - Bloco vazado de concreto simples para alvenaria requisitos 
- NBR 8949 (1985): Paredes de alvenaria estrutural - ensaio à compressão simples - método de ensaio

- NBR 12118 (2011) - Blocos vazados de concreto simples para alvenaria métodos de ensaio

- NBR 13279/05 - Argamassa para assentamento e revestimento de paredes e tetos - Determinação da resistência à tração na flexão e à compressão

- NBR 13281/05 - Argamassa para assentamento e revestimento de paredes e tetos - Requisitos

- NBR 14321 (1999): Paredes de alvenaria estrutural - determinação da resistência ao cisalhamento

- NBR 14322 (1999): Paredes de alvenaria estrutural - verificação da resistência à flexão simples ou à flexo-compressão

- NBR 15961-1: (2011) - Alvenaria estrutural - blocos de concreto. Parte 1: Projeto

- NBR 15961-2: (2011) - Alvenaria estrutural - blocos de concreto. Parte 2: Execução e controle de obra

A alvenaria estrutural com blocos de concreto é um sistema construtivo racionalizado que possibilita a redução da mão de obra empregada, do tempo de execução e dos custos da obra, quando comparada com o sistema tradicional de concreto armado (PRUDÊNCIO JR. et al., 2003).

O sistema de alvenaria estrutural com blocos de concreto apresenta, ainda, outras vantagens significativas (ABCP, 2002):

- redução de armaduras;

- redução de fôrmas;

- eliminação das etapas de moldagem dos pilares e vigas;

- facilidade na montagem da alvenaria; e

- redução de desperdícios e retrabalho.

De acordo com Prudêncio Jr. et al. (2003), neste sistema as paredes funcionam como elementos portantes e transferem as cargas diretamente para as fundações ou para a estrutura de transição. 
Por cumprir as funções de estrutura e vedação ao mesmo tempo, não é possível, nesse sistema, danificar ou modificar as paredes estruturais sem a verificação do projetista, no entanto, pode-se prever as paredes que têm mais probabilidade de serem alteradas e considerá-las não portantes para efeito de cálculo. Por essa razão, é importante que os moradores sejam devidamente informados e esclarecidos sobre essa questão.

De acordo com Parsekian (2012), os elementos da alvenaria são classificados em NÃO ARMADOS, quando a armadura é desconsiderada para resistir aos esforços solicitantes, ARMADOS, quando são utilizadas armaduras passivas que são consideradas para resistência aos esforços solicitantes, e PROTENDIDOS, quando são utilizadas armaduras ativas impondo uma pré-compressão antes do carregamento.

Segundo Prudêncio Jr. et al. (2003), como os componentes básicos da alvenaria, os blocos, possuem dimensões padronizadas, é possível utilizar a modulação da edificação, evitando desperdício de tempo e de materiais. Assim, estes autores afirmam que, antes de iniciar o projeto da alvenaria estrutural, é preciso definir a família de blocos que será utilizada e a espessura desses blocos, lembrando-se de definir também os elementos especiais pertencentes à família escolhida, tais como: os blocos canaletas, os blocos tipo "J" e os blocos compensadores.

Uma vez definida a família e a espessura dos blocos, é possível desenvolver o projeto da alvenaria, que deve ser concebida de forma modulada já nas primeiras etapas de projeto. De acordo com o Manual de Habitação 1.0, da ABCP (2002), "Modular é dispor os blocos em fiadas alternadas, amarrando os elementos e as paredes entre si com o mínimo possível de peças, sem quebras".

De acordo com a Comunidade da Construção (2012), para realizar a modulação, é utilizada uma unidade modular definida pelas medidas dos blocos, podendo ou não ser múltiplas umas das outras. Se as medidas não são múltiplas, é preciso utilizar elementos especiais pré-fabricados ou fabricados em canteiro para fazer o ajuste das paredes tanto na direção horizontal quanto na vertical, os chamados elementos compensadores.

Caso seja adotada a família 29, a unidade modular é 15 e múltiplos de 15 , onde 15 é a medida do bloco de $14 \mathrm{~cm}$ mais $1 \mathrm{~cm}$ de espessura das juntas. Assim, o 
comprimento dos blocos é sempre múltiplo da largura, o que evita o uso de elementos compensadores, exceto para ajuste de vãos de esquadrias (COMUNIDADE DA CONSTRUÇÃO, 2012).

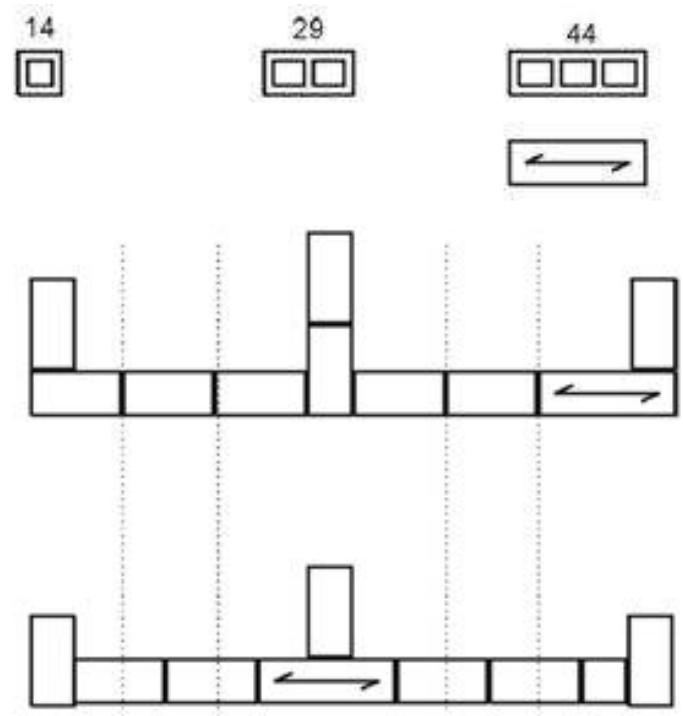

Figura 107 - Modulação utilizando a família 29 Fonte: COMUNIDADE DA CONSTRUÇÃO, 2012.

No caso de adoção da família 39, a unidade modular é 20 e múltiplos de 20 , sendo 20 a medida do bloco de $19 \mathrm{~cm}$ mais $1 \mathrm{~cm}$ de espessura das juntas. Se forem adotados blocos com largura de $14 \mathrm{~cm}$, serão necessários elementos compensadores para ajuste de vãos de esquadrias para modulação em planta baixa, sendo necessário o emprego do bloco especial B34 $(34 \times 19 \times 14 \mathrm{~cm})$ para ajuste nos encontros em "L" e em "T" (COMUNIDADE DA CONSTRUÇÃO, 2012). 


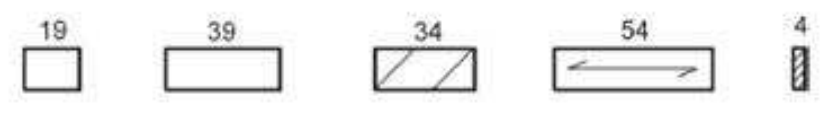

\section{CANTO}
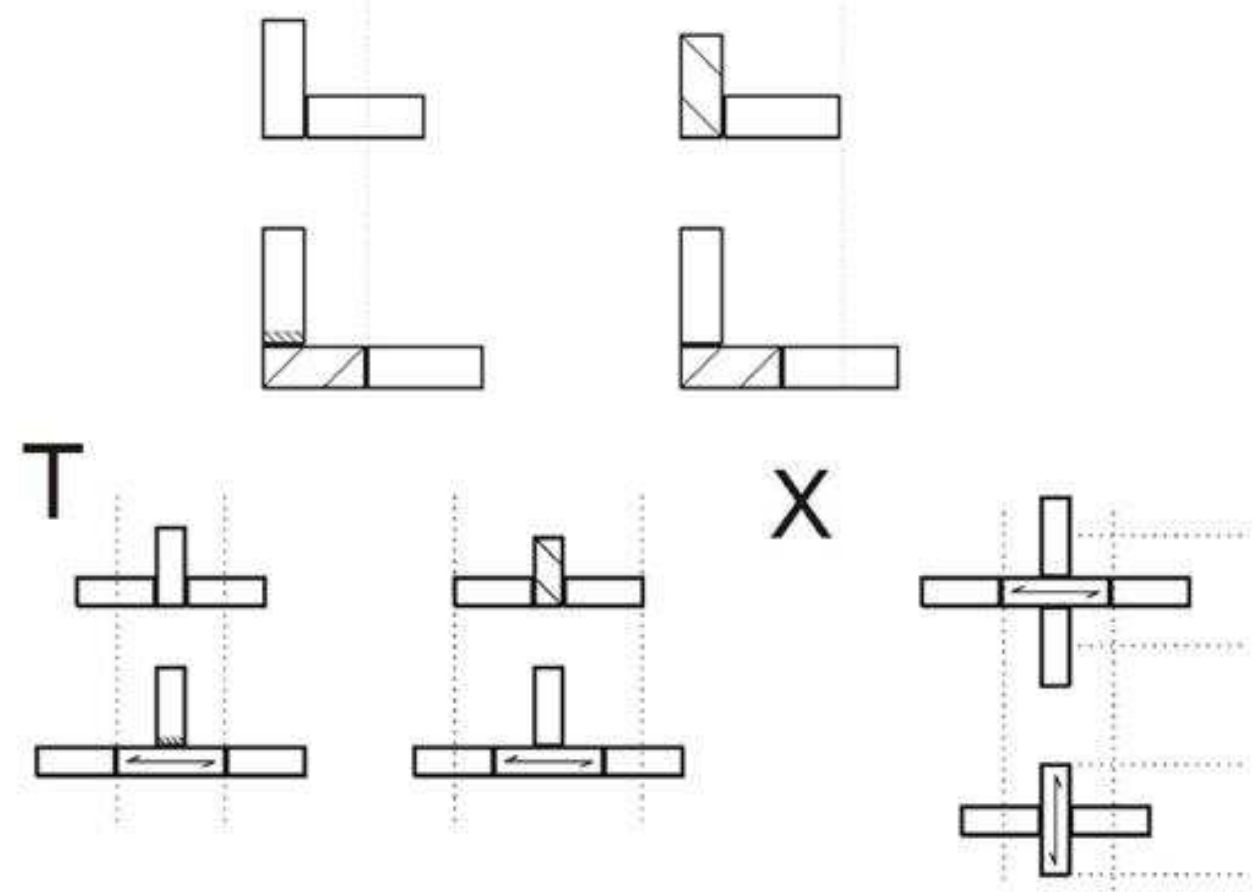

Figura 108 - Modulação utilizando a família 39

Fonte: COMUNIDADE DA CONSTRUÇÃO, 2012.

De acordo com Parsekian (2012), a norma NBR 15961-1 define dois tipos de amarração entre as paredes de blocos de concreto, a direta e a indireta. A amarração direta é sempre a mais recomendada e consiste na ligação de paredes por intertravamento de blocos, sendo obtida com a interpenetração alternada de $50 \%$ das fiadas de uma parede na outra ao longo das interfaces comuns. Já a amarração indireta é obtida através da ligação de paredes com junta vertical a prumo com o plano da interface comum sendo atravessado por grampos metálicos ancorados nos furos verticais adjacentes.

Assim, é importante que o projetista conheça bem o sistema construtivo empregado para que o projeto seja o mais detalhado possível e tenha soluções que visem reduzir ao máximo a quantidade de componentes utilizados na produção (ABCP, 2002). 
Prudêncio Jr. et al. (2003), salientam, ainda, que deve haver compatibilização entre os projetos arquitetônico, estrutural e complementares para que todas essas informações sejam compiladas em um projeto de produção. Esse projeto deve conter plantas baixas e elevações das paredes com detalhes arquitetônicos, estruturais, de instalações elétricas, hidráulicas e outras que sejam necessárias (ABCP, 2002). Assim, esse projeto compatibilizado e de fácil execução será levado ao canteiro para ser utilizado pelo mestre, encarregados e operários.

A NBR 15961-2 (ABNT, 2011) determina, também, os principais procedimentos de execução e controle das alvenarias estruturais com blocos de concreto. Uma destas determinações é a de que as juntas de assentamento horizontais e verticais devem ter espessura de $10 \mathrm{~mm} \pm 3 \mathrm{~mm}$, com exceção da junta horizontal da primeira fiada, que pode variar entre $5 \mathrm{~mm}$ e $20 \mathrm{~mm}$ de acordo com o desnivel do pavimento. As juntas horizontais devem, preferencialmente, ser colocadas nas paredes longitudinais e transversais dos blocos, a menos que o projeto especifique o contrário. Já as juntas verticais devem ser preenchidas através da aplicação de dois filetes de argamassa na parede lateral dos blocos, com largura igual ou superior a $30 \mathrm{~mm}$.

Parsekian (2012), afirma que, para edifícios de até 5 pavimentos, a junta vertical pode ser preenchida 15 dias após a elevação total da parede utilizando argamassa não retrátil aplicada com bisnaga com compressão suficiente para garantir largura mínima do filete de argamassa vertical. Nos demais casos, o autor ressalta que o preenchimento da junta deve ser feito durante a execução da parede.

Com relação às armaduras, tanto verticais quanto horizontais, Parsekian (2012) recomenda que tenham um cobrimento mínimo de $15 \mathrm{~cm}$, salvo se tiverem alguma proteção contra corrosão, podendo ser utilizados espaçadores para garantir essa condição.

Parsekian (2012), afirma, ainda, que a armadura de canto, nos encontros de paredes, é necessária em algumas situações, apesar de ser de difícil execução. $O$ autor salienta que os cantos externos dos edifícios sempre devem ter uma armadura construtiva, geralmente de $10 \mathrm{~mm}$, independentemente da altura da construção. Em edifícios com mais do que 5 pavimentos, é recomendável utilizar essa armadura também nos encontros de paredes principais. 
Segundo Parsekian (2012), as armaduras das vergas, quando executadas com canaletas grauteadas, devem sempre ser dimensionadas e os apoios devem ter no mínimo $15 \mathrm{~cm}$ para comprimento de até $1,0 \mathrm{~m}$ e $30 \mathrm{~cm}$ para comprimentos superiores. Já na contraverga, a armadura é construtiva e geralmente constituída de uma barra de $10 \mathrm{~mm}$ ou treliça TR08 com apoios de no mínimo $30 \mathrm{~cm}$.

Os eletrodutos são embutidos na vertical dentro dos furos dos blocos e na horizontal nas lajes ou nos forros. Já no tocante às instalações hidrossanitárias, é recomendável que estas não sejam embutidas nas paredes para permitir a manutenção sem a necessidade de quebrar a alvenaria (ABCP, 2002), entretanto, nas casas de Lagoinha essas tubulações foram embutidas.

Deve ser prevista a execução de uma cinta de respaldo para amarrar o topo das paredes e dar mais estabilidade à estrutura. Essa cinta é constituída de canaletas grauteadas, com ou sem armação horizontal, e deve ser localizada, preferencialmente, na última fiada de blocos (PARSEKIAN, 2012).

Segundo Parsekian (2012), a utilização de lajes maciças moldadas no local, ou suas variações como uso de pré-laje com capa moldada no local, permite uma boa distribuição das cargas verticais e comportamento como diafragma rígido na maioria dos casos. Assim, o simples apoio da laje sobre a cinta de respaldo é suficiente para transmitir, por atrito, os esforços verticais e horizontais sem a necessidade de armadura vertical de ligação. Nesse caso, a cinta de respaldo deve ser sempre posicionada na última fiada, e deve ser grauteada antes da concretagem da laje. No caso de Lagoinha, foram executadas lajes maciças de concreto em toda a casa.

Bauer (2006) lembra, ainda, que "cuidados no projeto e na execução das obras evitam problemas nos edifícios construídos com alvenaria estrutural". De acordo com o autor, as fissuras são as patologias mais encontradas na alvenaria estrutural com blocos de concreto e é importante conhecer suas causas para definir o tratamento mais adequado. As tabelas a seguir apresentam as principais configurações e causas das fissuras em alvenarias estruturais com blocos de concreto: 
Tabela 8 - Tipologias e prováveis causas de fissuras verticais

\begin{tabular}{|l|l|} 
Resistência à tração do bloco vazado de concreto é superior à resistência \\
à tração da argamassa.
\end{tabular}

Fonte: Bauer, 2006.

Tabela 9 - Tipologias e prováveis causas de fissuras inclinadas

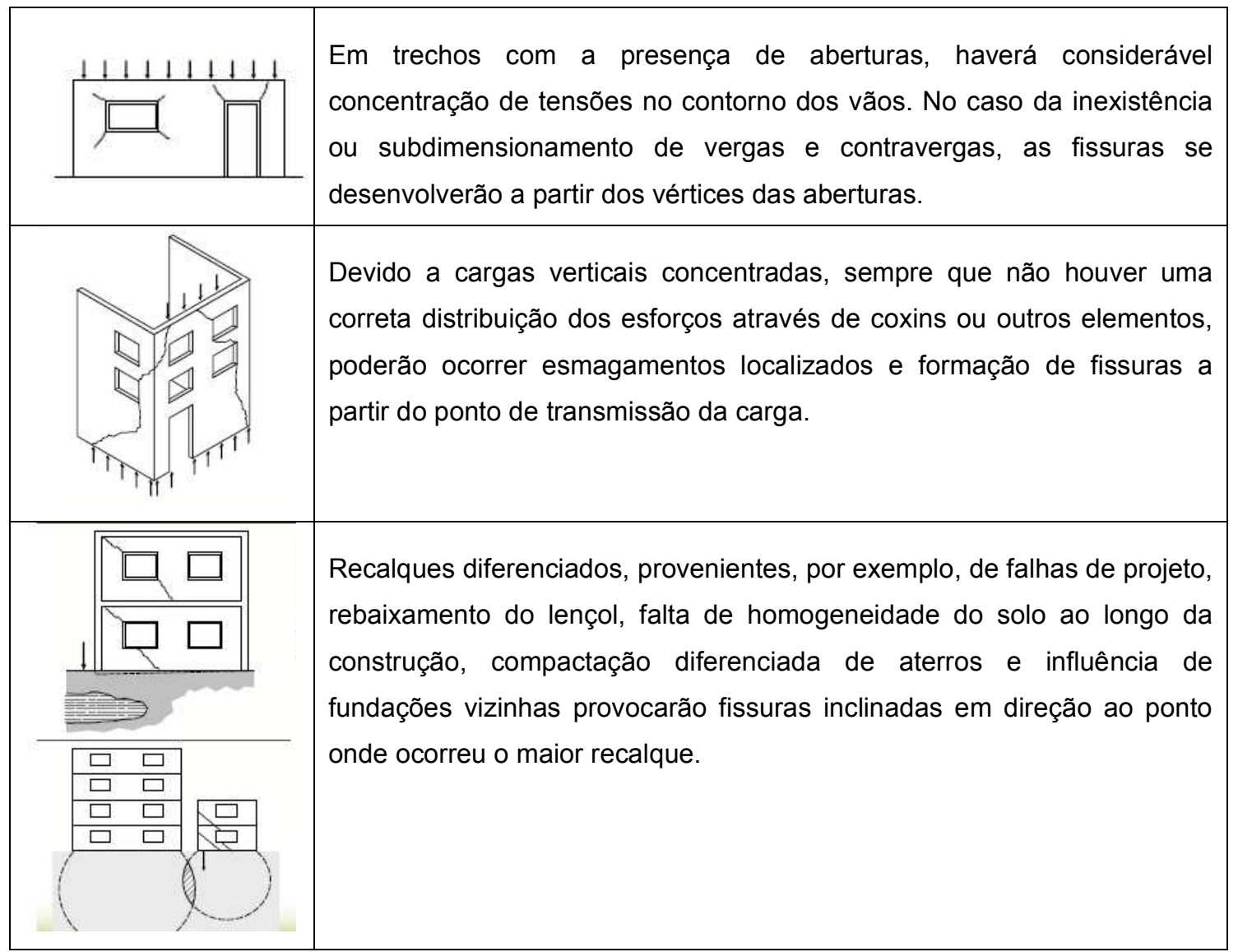

Fonte: Bauer, 2006. 
Tabela 10 - Tipologias e prováveis causas de fissuras horizontais

\begin{tabular}{|c|c|}
\hline $\mid$\begin{tabular}{|l|}
$\mid+\infty$ \\
$+\infty$
\end{tabular} & $\begin{array}{l}\text { As fissuras horizontais nas alvenarias, causadas por sobrecargas } \\
\text { verticais atuando axialmente no plano da parede, não são frequentes; } \\
\text { poderão ocorrer, entretanto, pelo esmagamento da argamassa das juntas } \\
\text { de assentamento. Tais fissuras, contudo, não são muito raras em paredes } \\
\text { submetidas à flexocompressão. }\end{array}$ \\
\hline 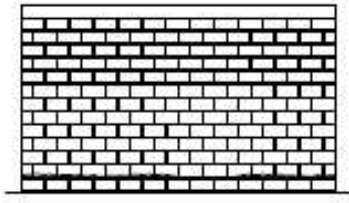 & $\begin{array}{l}\text { Em alvenarias pouco carregadas, a expansão diferenciada entre fiadas } \\
\text { de blocos pode provocar, por exemplo, a ocorrência de fissuras } \\
\text { horizontais na base das paredes. }\end{array}$ \\
\hline & $\begin{array}{l}\text { Na retração por secagem de grandes lajes de concreto armado sujeitas a } \\
\text { forte insolação poderá ocorrer fissuração, devido ao encurtamento da } \\
\text { laje, que provocará uma rotação nas fiadas de blocos próximos à laje. }\end{array}$ \\
\hline & $\begin{array}{l}\text { Devido a movimentações térmicas, surgirão fissuras idênticas àquelas } \\
\text { relatadas para a movimentação higroscópica e retração por secagem. } \\
\text { Estas serão mais intensas nas lajes de cobertura e poderão ser evitadas } \\
\text { com um cintamento muito rígido ou sistema de apoio deslizante. }\end{array}$ \\
\hline
\end{tabular}

Fonte: Bauer, 2006.

Ainda de acordo com Bauer (2006), as manifestações mais comuns ligadas à umidade em edificações são as manchas de umidade, corrosão, bolor, fungos, algas, líquens, eflorescências, descolamentos de revestimentos, friabilidade da argamassa por dissolução de compostos com propriedades cimentíceas, fissuras e mudança de coloração dos revestimentos. Ele explica que diversos fatores podem gerar umidade nos materiais de construção, como:

- absorção capilar de água do solo;

- absorção de água de infiltração ou de fluxo superficial de água;

- absorção higroscópica de água;

- absorção de água por condensação capilar;

- absorção de água por condensação (por exemplo: teto do banheiro);

- infiltração pelos componentes da alvenaria;

- infiltração pelas juntas de assentamento;

- geometria das fachadas desfavorável e superfícies horizontais sem inclinação mínima de 1\%; 
- prumadas externas de águas pluviais mal posicionadas ou danificadas;

- falhas na isolação térmica e impermeabilização das lajes;

- infiltração de água pelas fissuras e trincas do revestimento ou alvenarias;

- problemas de estanqueidade nos caixilhos;

- infiltrações relacionadas a outros fatores, como falta ou deficiência das pingadeiras, molduras, cimalhas, peitoris e frisos.

Outra patologia comum, segundo Bauer (2006), é o surgimento de eflorescências. A eflorescência, segundo ele, é resultado de depósitos salinos na superfície de alvenarias, provenientes da migração de sais solúveis nos materiais e componentes da alvenaria, e ocorre quando outras duas condições aparecem simultaneamente: presença de água e pressão hidrostática necessária para que a solução migre para a superfície. Assim, pelo menos uma das três condições deve ser eliminada para se evitar a sua presença.

\subsubsection{Procedimentos de execução}

Prudêncio Jr. et al. (2003), salientam que, para que sejam obtidas todas as vantagens da alvenaria estrutural com blocos de concreto, é necessário o emprego de técnicas construtivas adequadas para gerar aumento de produtividade e economia.

Antes de iniciar a execução, é necessário definir os locais de armazenamento dos materiais e produção dos componentes da alvenaria. Neste estudo de caso, foram utilizados blocos de $9 \times 19 \times 39$ fabricados no canteiro e argamassa feita na obra, o que exigiu a definição e organização também dos locais de produção.

Também é necessário verificar a disponibilidade e organizar todas as ferramentas e equipamentos necessários para a execução da obra.

As casas de alvenaria estrutural do Conjunto Habitacional Lagoinha "A" foram construídas de acordo com os procedimentos básicos de execução do sistema (ABCP, 2002; COMUNIDADE DA CONSTRUÇÃO, 2011):

\section{Etapa 1: Execução do radier}

Execução de fundação tipo radier, deixando todas as esperas e tubulações de água, esgoto, elétrica etc. Caso haja falhas inferiores a $30 \mathrm{~mm}$ no 
nivelamento, estas devem ser corrigidas com enchimento na primeira fiada da alvenaria. Caso o desnível seja superior a $30 \mathrm{~mm}$, a correção deve ser realizada com o mesmo concreto do radier.

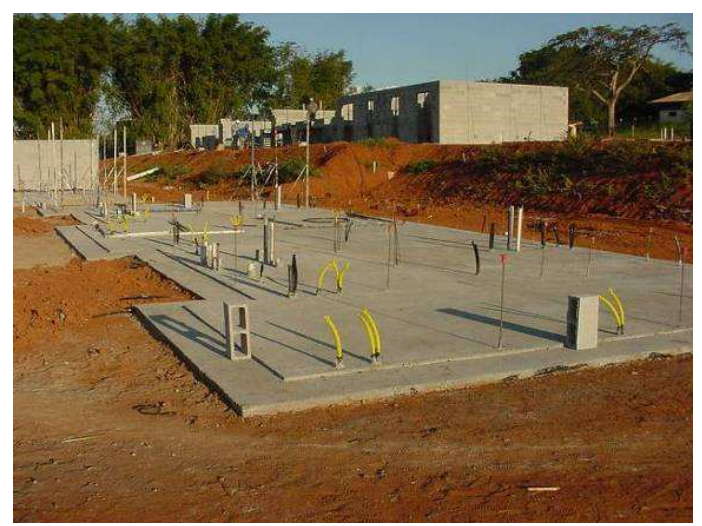

Figura 109 - Execução do radier Fonte: Acervo ABCP.

\section{Etapa 2: Limpeza e verificação}

O pavimento deve ser limpo e desobstruído. Em seguida, deve-se verificar o posicionamento das instalações e armaduras de espera em relação ao eixo para garantir que estas ficarão posicionadas dentro das paredes.

\section{Etapa 3: Verificação do esquadro}

Verificar o esquadro da obra. Se o pavimento for retangular, utilizar o critério da igualdade entre as diagonais com uma tolerância de $\pm 5 \mathrm{~mm}$ a cada $10 \mathrm{~m}$.

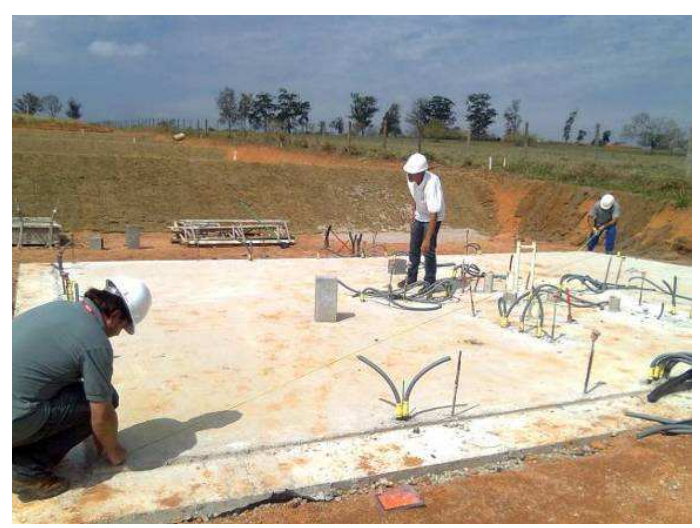

Figura 110 - Conferência das diagonais do pavimento Fonte: Acervo ABCP. 


\section{Etapa 4: Marcação das paredes}

Marcar a direção das paredes, vãos de portas e shafts utilizando a linha traçante (também chamado de "cordex"). Deve-se, também, conferir as referências com o gabarito de marcação ou locação da obra. A marcação das paredes perpendiculares pode ser feita usando as medidas 3,4 e 5 . Com as paredes já marcadas, é recomendável verificar novamente o posicionamento das tubulações e armaduras.

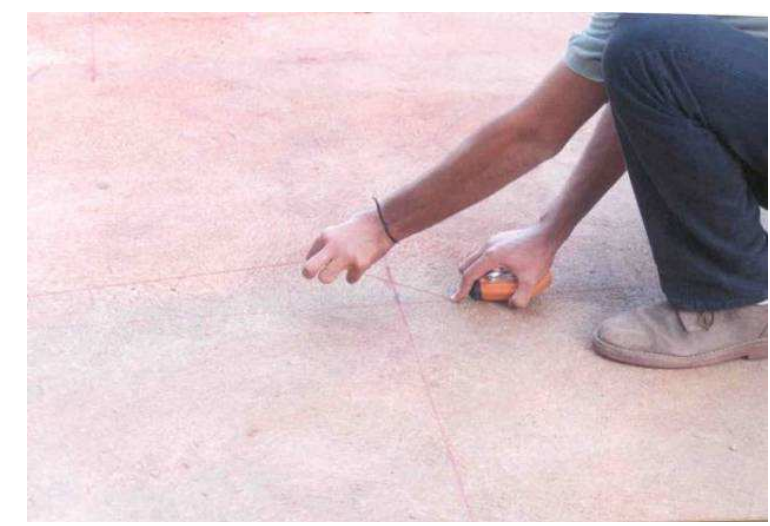

Figura 111 - Marcação das paredes com o "cordex" Fonte: Acervo ABCP.

\section{Etapa 5: Instalação dos escantilhões}

Os escantilhões devem ser posicionados de acordo com o projeto e a sua fixação é feita com uso de pregos de aço ou com bucha e parafuso. Em seguida, deve-se colocar esses escantilhões no prumo com o auxílio de uma régua prumo-nível ou de um fio de prumo convencional.

Os escantilhões podem ser de três tipos: industrializado com base fixa, industrializado com base móvel e de madeira, produzido na obra.
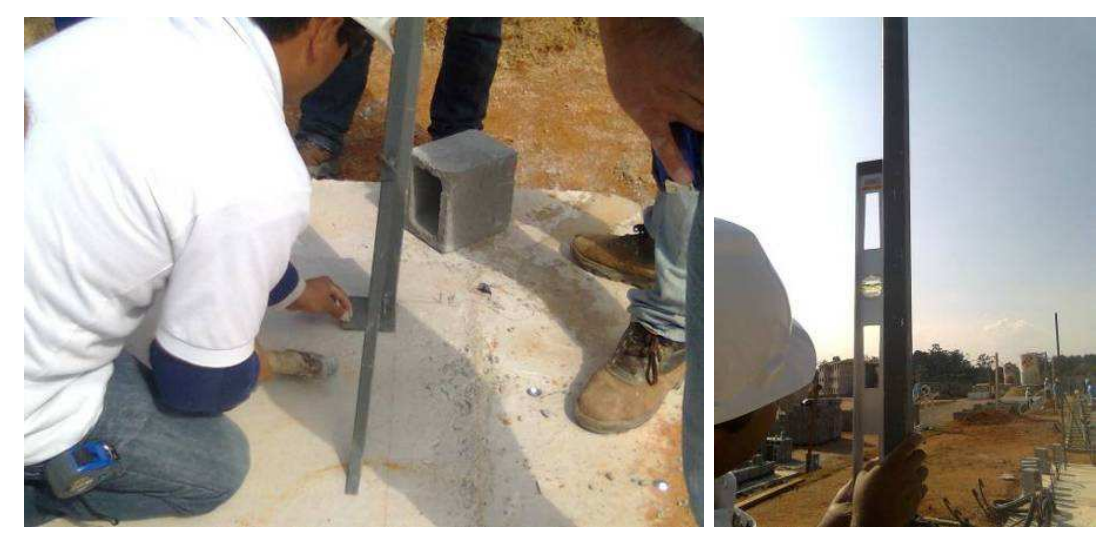

Figura 112 - Instalação dos escantilhões Fonte: Acervo ABCP. 


\section{Etapa 6: Criação das referências das fiadas}

As hastes dos escantilhões devem possuir marcas para determinar a altura das fiadas. Nos industrializados, essas marcas já vêm impressas e naqueles produzidos em obra essas marcas devem ser riscadas com lápis. No ponto mais alto do pavimento, marca-se $20 \mathrm{~cm}$ a partir do piso e, com a ajuda de um nível alemão ou a laser, transfere-se esse nível para todos os escantilhões, fazendo com que a primeira marca nas hastes coincida com esse nível. Marcam-se, então, as referências das fiadas com o auxílio de linhas de nylon ou barbante, interligando as marcas nos escantilhões.

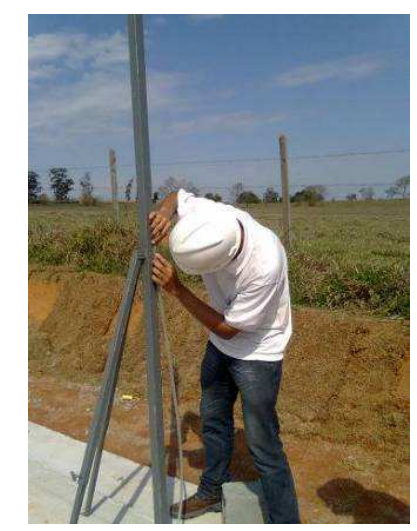

Figura 113 - Marcação das referências das fiadas Fonte: Acervo ABCP.

\section{Etapa 7: Instalação dos gabaritos de portas}

Ainda na fase de colocação dos escantilhões, instalam-se os gabaritos de portas nos vãos já marcados no pavimento.

\section{Etapa 8: Execução da $1^{\text {a }}$ fiada}

Primeiramente, deve-se molhar a superfície do pavimento na direção da parede e em seguida, com a colher de pedreiro, aplica-se a argamassa na largura aproximada do bloco, criando um sulco com a extremidade da colher. Assentam-se, então, os blocos de concreto, observando a amarração conforme o projeto. É importante locar corretamente os blocos com aberturas destinadas à limpeza dos pontos que serão grauteados. 

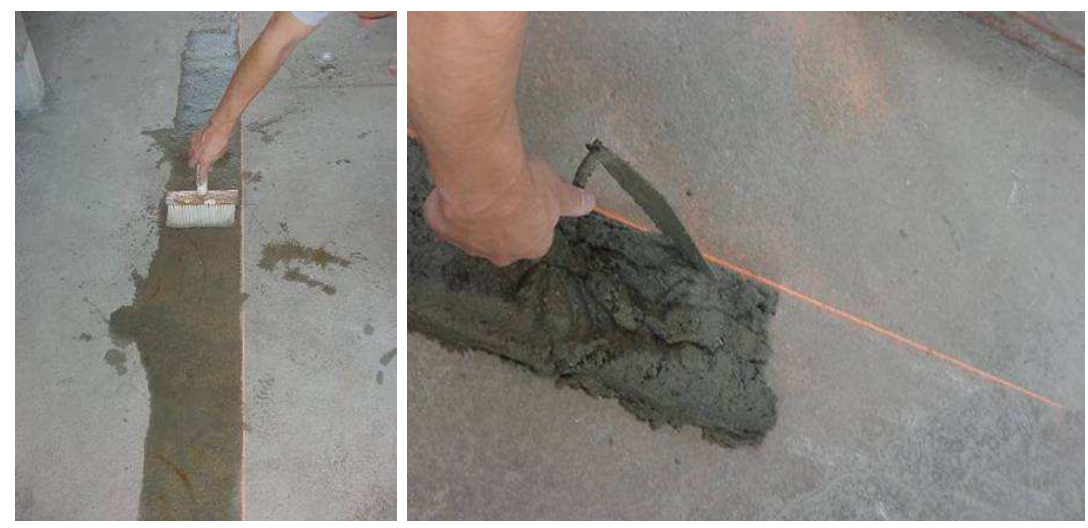

Figura 114 - Execução da $1^{a}$ fiada da alvenaria Fonte: Acervo ABCP.

\section{Etapa 9: Execução das demais fiadas}

Para o assentamento das demais fiadas de blocos, pode-se utilizar a palheta, bisnaga ou meia-cana para a aplicação do cordão de argamassa de assentamento nas paredes longitudinais dos blocos. Nas paredes transversais dos blocos pode-se utilizar a bisnaga ou a colher de pedreiro. Utilizar a colher para retirar o excesso de argamassa após o assentamento de cada bloco e não deslocá-lo da posição depois de assentado. As juntas verticais podem ser preenchidas durante o assentamento com colher de pedreiro ou posteriormente com a bisnaga. Durante toda a execução da alvenaria, devem ser verificados o nível e o alinhamento, garantindo a precisão dimensional da parede.

O assentamento de blocos tipo "U" (canaleta), tipo "J" e tipo compensador para a execução de cintas, vergas e contravergas e o posicionamento das armaduras devem ser realizados de acordo com o projeto estrutural.

Juntamente com a elevação da alvenaria, passa-se a tubulação elétrica e as armaduras verticais, que devem ser amarradas às armaduras de espera do radier. No caso de Lagoinha, as instalações elétricas e hidráulicas foram embutidas nas paredes através da realização de rasgos na alvenaria, o que não é recomendado.

É importante ressaltar que, no caso de chuvas, as paredes deverão ser protegidas. 

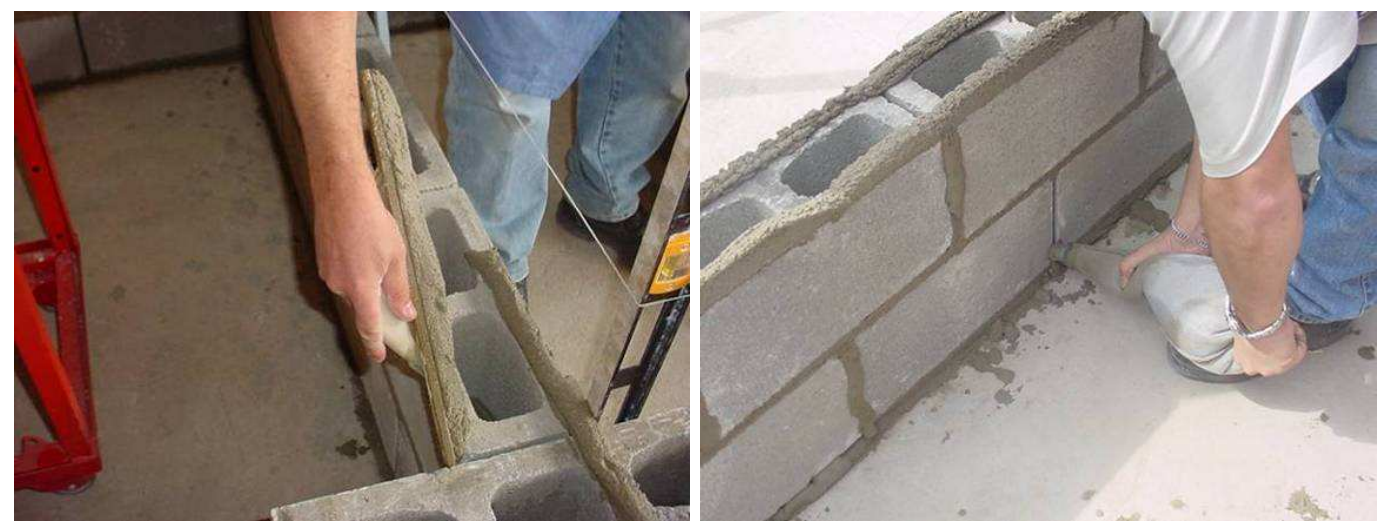

Figura 115 - Utilização de palheta e bisnaga na elevação da alvenaria Fonte: Acervo ABCP.

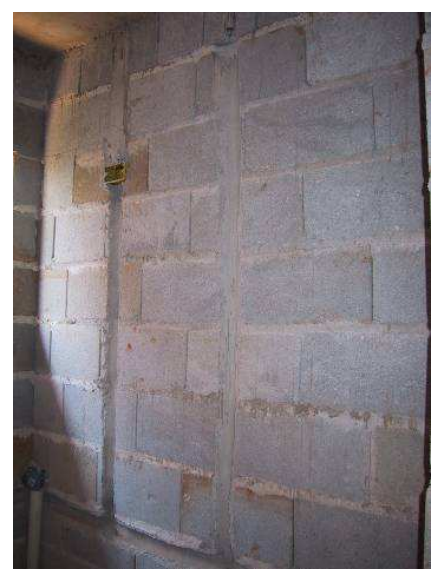

Figura 116 - Passagem de instalações no interior das alvenarias em Lagoinha Fonte: Acervo ABCP.

\section{Etapa 10: Grauteamento}

Antes de realizar o grauteamento vertical, deve-se limpar o interior dos furos dos blocos para retirar o excesso de argamassa de assentamento e tampar os furos de inspeção com madeira. Em seguida, lança-se o graute a uma altura máxima de 1,6 m, podendo ser utilizada uma barra de aço para ajudar no adensamento.

O lançamento do graute nas cintas, vergas e contravergas deve ser realizado de forma que as armaduras não saiam da posição. 


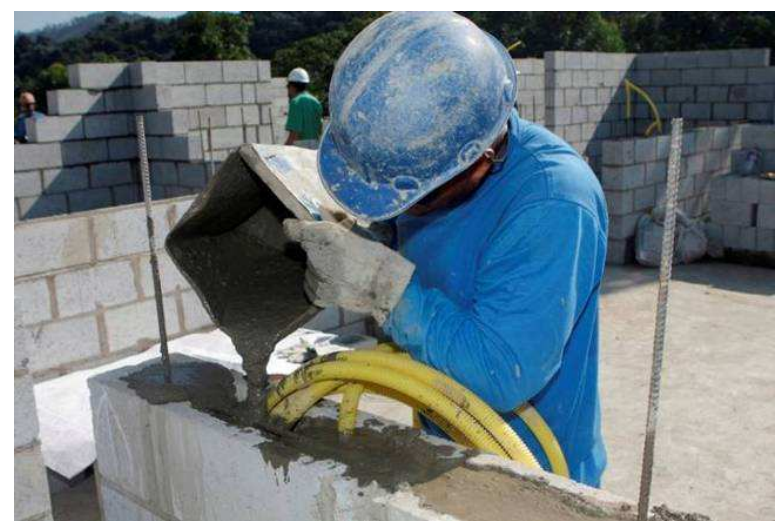

Figura 117 - Grauteamento vertical da alvenaria Fonte: Acervo ABCP.

\section{Etapa 11: Execução da laje}

Após o grauteamento da cinta de respaldo, é executada a laje maciça moldada no local.

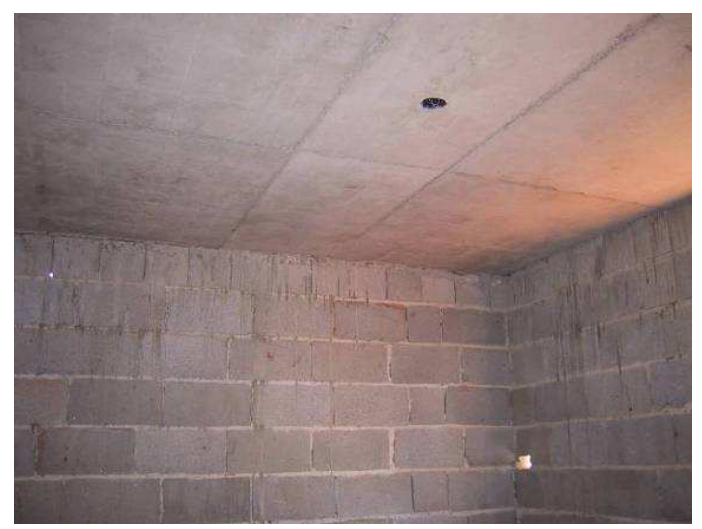

Figura 118 - Laje maciça moldada in loco em casa de Lagoinha Fonte: Acervo ABCP.

\section{Etapa 12: Execução da Cobertura}

Em seguida, executa-se a estrutura do telhado, que no caso de Lagoinha é metálica, e a colocação das telhas. 

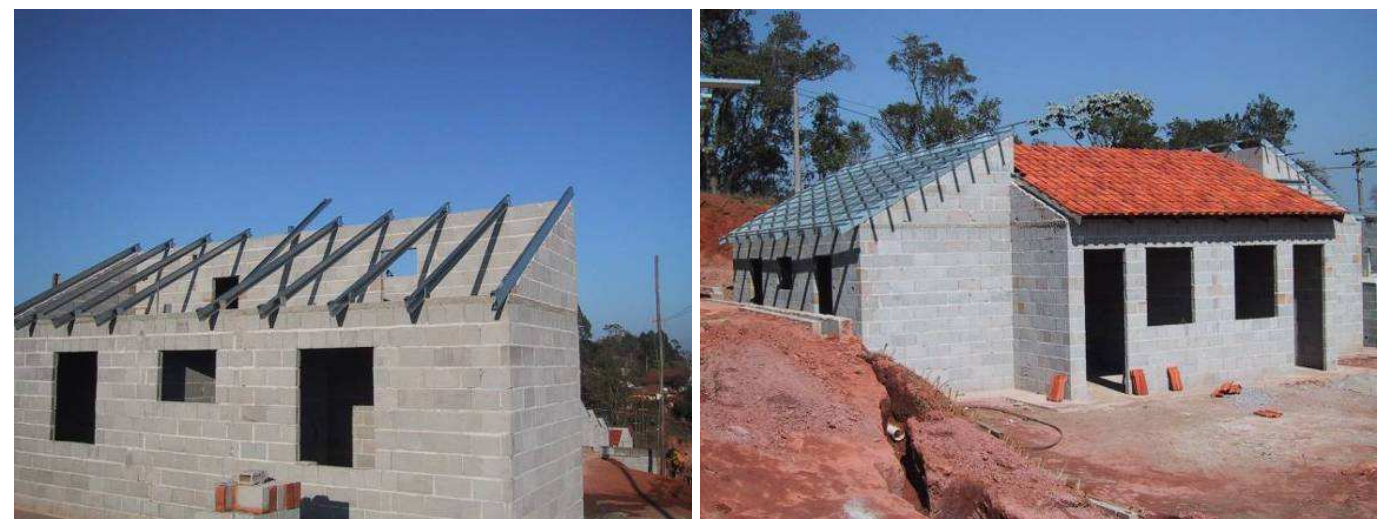

Figura 119 - Execução cobertura nas casas de Lagoinha Fonte: Acervo ABCP.

\section{Etapa 13: Colocação das esquadrias}

São instaladas as portas e janelas.

\section{Etapa 14: Revestimentos e acabamentos}

Após a elevação, aplica-se o revestimento argamassado e massa corrida nas paredes internas, com posterior pintura. Também são realizados outros acabamentos, como instalação de louças e metais.

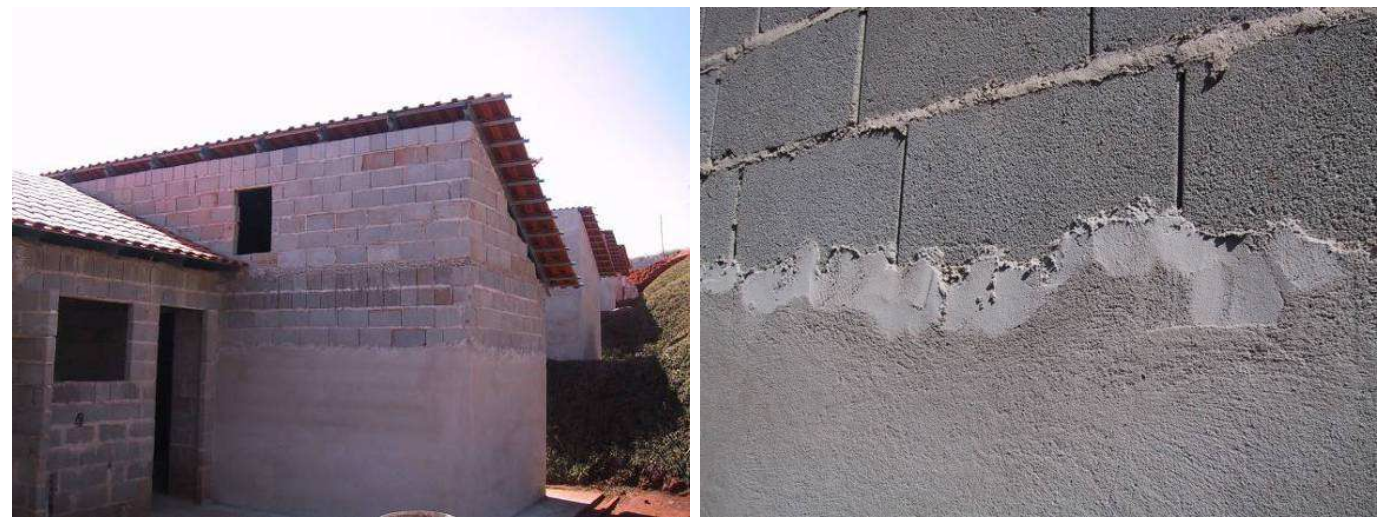

Figura 120 - Execução do revestimento das casas de Lagoinha Fonte: Acervo ABCP.

Em função da forma de participação da $A B C P$ neste empreendimento, já mencionada no item 8.1.2, e do tempo decorrido desde a execução do empreendimento, não foram localizadas fotos de todas as etapas de execução do Conjunto Habitacional Lagoinha "A". Assim, é importante destacar que foram utilizadas fotos de outras obras para ilustrar algumas etapas de execução do 
sistema, sendo que as fotos que ilustram a obra em questão estão claramente identificadas nas legendas.

\subsubsection{Aplicação em moradia popular}

De acordo com a Comunidade da Construção (2012), a alvenaria estrutural é um processo construtivo consolidado, que pode ser utilizado em qualquer tipo de empreendimento com grande economia. Trata-se de um sistema de fácil execução e, portanto, permite envolver a mão de obra local, além de permitir a ampliação das unidades.

Segundo a Comunidade da Construção (2012), devido à precisão dimensional e variedade de resistências dos blocos de concreto, pode ser empregada em diversas tipologias habitacionais. Além disso, por ser um processo racionalizado, permite rapidez na construção com um custo adequado aos padrões da habitação popular. Além disso, destacam-se as seguintes vantagens do sistema:

- facilidade de controle - normas técnicas para projeto, materiais e execução;

- técnica executiva simplificada - execução mais fácil, prática e produtiva.

- facilidade de treinamento - etapas de execução são similares às da técnica tradicional de execução de paredes.

- $\quad$ redução do volume de revestimento - regularidade das paredes.

- redução do desperdício - compatibilização com outros subsistemas.

- $\quad$ otimização da mão de obra - menos funções na obra.

Por essas razões, a alvenaria estrutural tem sido amplamente utilizada em empreendimentos de HIS no Brasil, sejam eles promovidos pela CDHU, COHAB ou pelas prefeituras dos municípios em todas as regiões do país.

\subsection{O Estudo de caso}

Foi realizada uma visita ao empreendimento Lagoinha "A", com a participação de dois pesquisadores, para entrevistar os moradores e colher informações sobre as casas e modificações realizadas após a entrega destas pela CDHU. 
Nessa ocasião, foram visitadas 10 unidades habitacionais de alvenaria estrutural, nomeadas com a sigla LGN, que identifica o empreendimento, e os números de 01 a 10, sendo que cada uma delas recebeu um nome de LGN01 a LGN10, na ordem de realização das visitas.

Foram realizadas, ainda, visitas às quatro unidades habitacionais construídas com estrutura metálica e paredes de concreto, sendo duas com cada processo. Essas casas receberam os nomes de LGN11 a LGN14, sendo as casas 11 e 12 construídas com estruturas metálicas e as casas 13 e 14 construídas com paredes de concreto celular moldadas in loco.

No dia da realização das visitas a temperatura chegou a $31^{\circ}$ no início da tarde e no final do dia houve uma forte tempestade, que começou quando já estava sendo realizada a última visita, que não foi comprometida pela chuva.

\subsubsection{Apresentação e Análise dos Resultados das Entrevistas}

Para a realização de entrevistas com os moradores, foi utilizado o formulário padrão apresentado no Apêndice $B$, porém, com a planta da tipologia utilizada no Conjunto Habitacional Lagoinha "A". Os resultados apresentados neste item referemse às 14 casas visitadas, independentemente do sistema construtivo de cada uma delas.

A média de moradores por residência é de 3,57, variando entre 2 e 6 moradores por unidade habitacional.

Das casas visitadas, apenas uma está quitada e as demais ainda então financiadas, o que representa $86 \%$ dessas casas, sendo que destas, uma está alugada para terceiros. Verificou-se, ainda, que $79 \%$ das famílias entrevistadas está morando no imóvel desde a entrega.

Assim como nos estudos de caso anteriores, observou-se que todas as residências contam com os bens de consumo básicos, como fogão, geladeira, televisão e chuveiro elétrico. O gráfico a seguir apresenta a porcentagem de famílias que possui cada bem de consumo: 


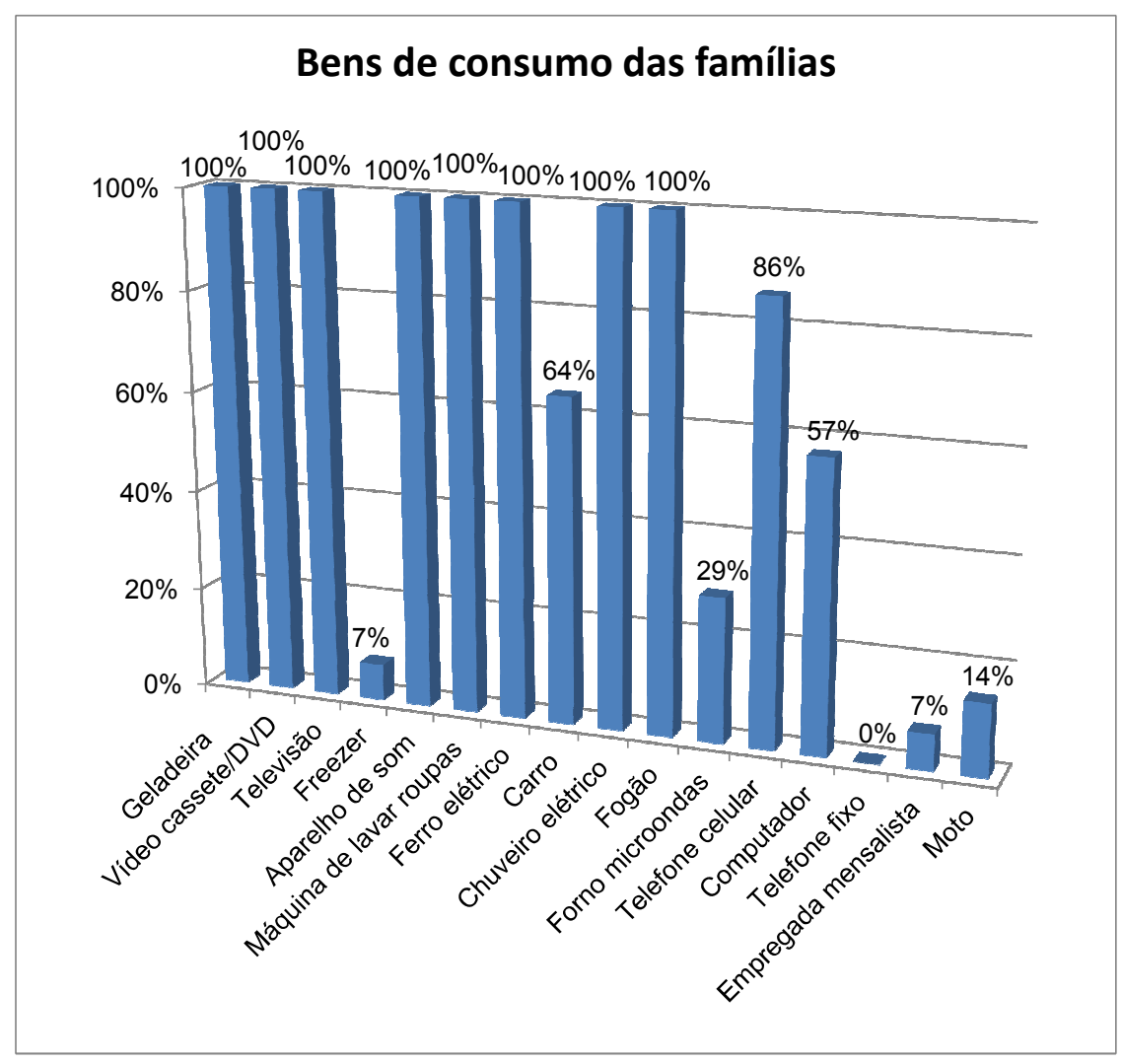

Gráfico 39 - Estudo de Caso 3: Bens de consumo das famílias

Com relação à avaliação da casa entregue, 73\% dos moradores entrevistados consideram que a casa NÃO foi entregue completa, o que pode ser atribuído ao fato de as casas terem sido entregues sem o acabamento completo e sem muros e portões. Ainda assim, todos os moradores consideram que a casa entregue atende a todas as necessidades da família. É facilmente perceptível, na fala dos moradores, o amor e orgulho que têm pelas casas, sobretudo aqueles que participaram da construção delas, principalmente depois das modificações e personificações realizadas após a entrega destas.

Assim como no estudo de caso anterior, que apresenta a mesma tipologia habitacional, foram muitas as reclamações pelo fato de as casas serem geminadas e, também, porque a sala e a cozinha não são separadas fisicamente, sendo citados os mesmos motivos relatados pelos moradores do Conjunto Habitacional Cunha "B". 


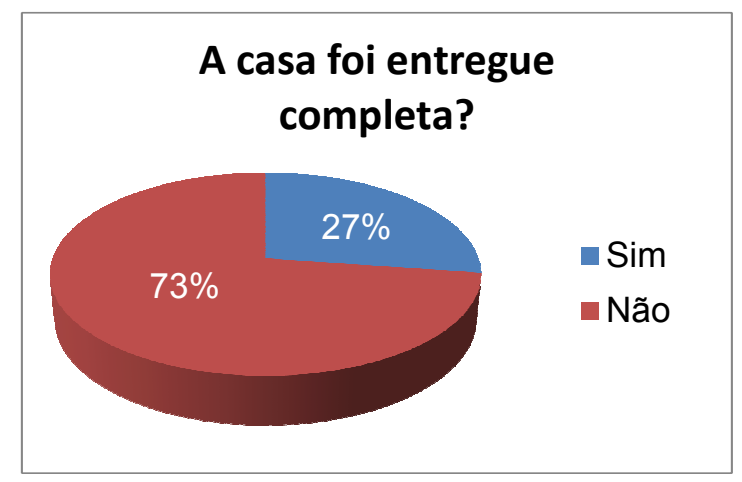

Gráfico 40 - Estudo de Caso 3: Avaliação da casa recebida

Com relação à ocorrência de problemas construtivos e patologias, 57\% dos entrevistados afirmaram ter tido algum tipo de problema, sendo que a totalidade destes moradores afirma ter problemas com umidade e infiltração, mas sem presença de mofo. Também foram feitas reclamações com relação à movimentação do aterro e à presença de fissuras e trincas nas paredes e no piso do quintal.

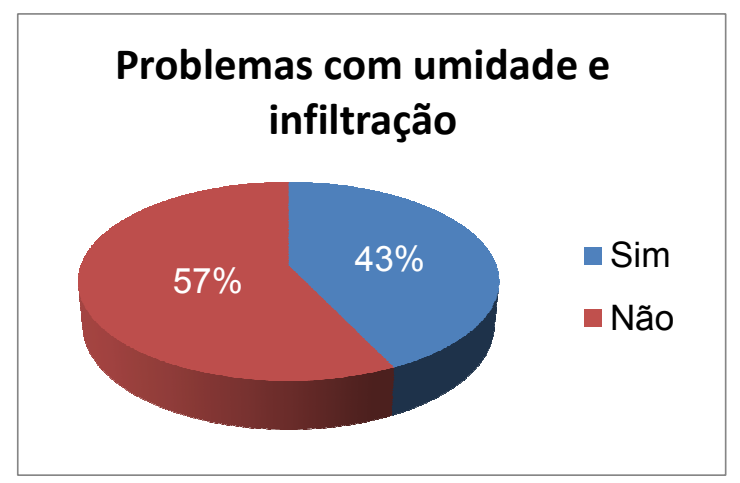

Gráfico 41 - Estudo de Caso 3: Problemas com umidade e infiltração

Dos moradores que relataram problemas com umidade e infiltração, 67\% afirmam que o problema está na região das paredes próximas ao piso e $33 \%$ dizem ter problemas no topo das paredes e nas lajes.

Já com relação à iluminação e ventilação, as avaliações dos moradores foram boas, chegando a $7 \%$ de avaliações ótimas, $79 \%$ de avaliações boas e $14 \%$ de avaliações regulares no quesito iluminação. Já no quesito ventilação, $7 \%$ dos entrevistados consideram-na ótima e 93\% consideram-na boa. 


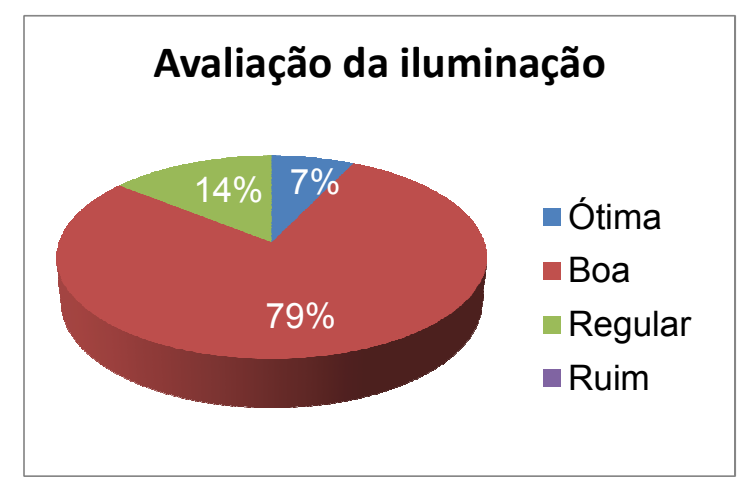

Gráfico 42 - Estudo de Caso 3: Avaliação da iluminação

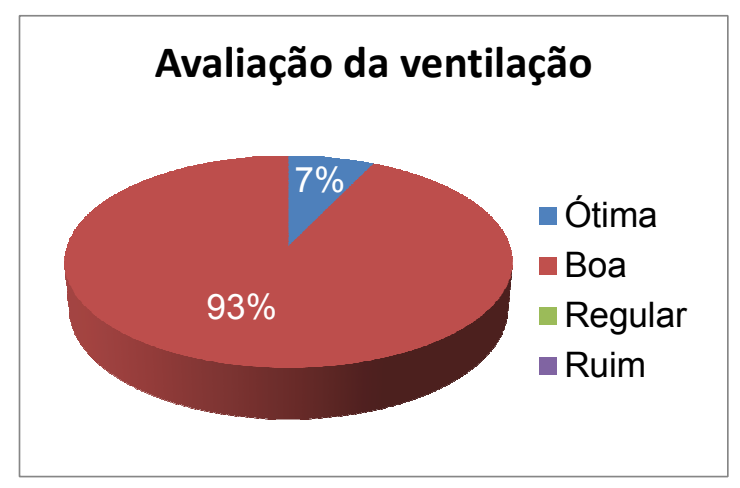

Gráfico 43 - Estudo de Caso 3: Avaliação da ventilação

Outra constatação importante foi a de que todas as casas sofreram algum tipo de modificação após a entrega, fato facilmente explicável, uma vez que as casas foram entregues sem o acabamento completo. Segundo os moradores, não foi fornecido nenhum tipo de projeto para a realização de reformas e ampliações nas casas, mas eles relatam que foi apresentada, nas reuniões com a CDHU, a possibilidade de ampliação através da construção de um terceiro dormitório, conforme apresentado na figura 102.

Essas modificações foram realizadas, parte por pedreiros contratados e parte pelos próprios moradores ou algum membro da família, parentes ou amigos. Verificou-se, ainda, que essas modificações foram sendo realizadas ao longo do tempo e que em quase $80 \%$ dos casos a última modificação foi realizada há mais de um ano, mas ainda há modificações em execução. Os gráficos a seguir detalham estes números:

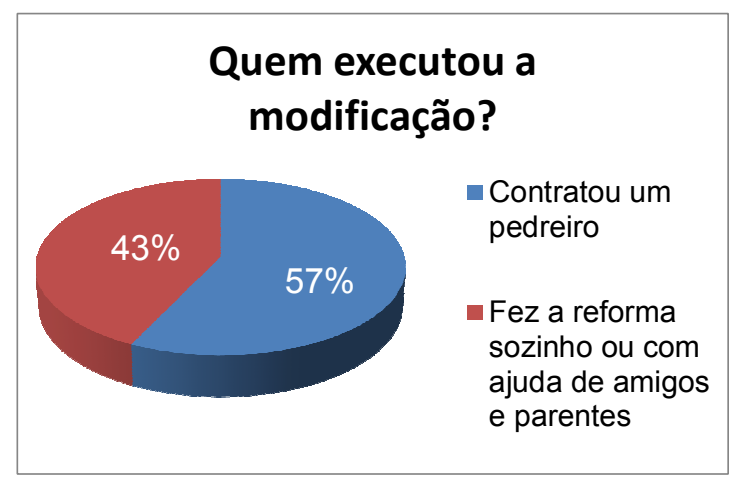

Gráfico 44 - Estudo de Caso 3: Agente realizador das modificações 


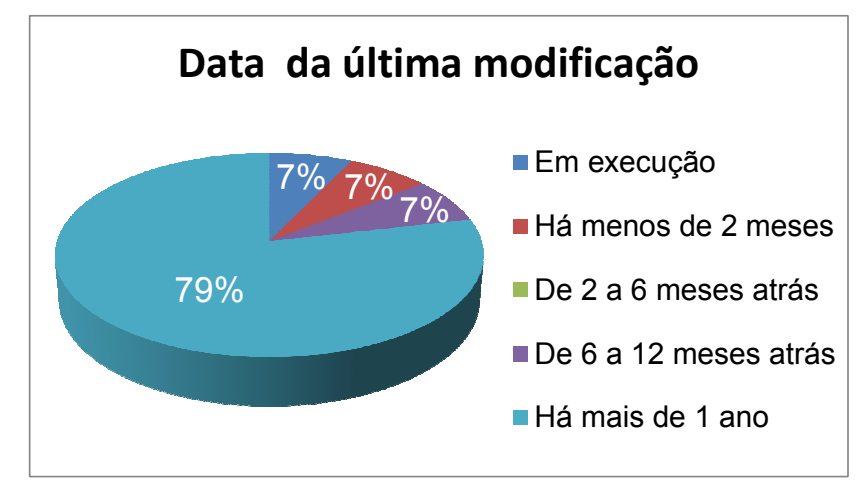

Gráfico 45 - Estudo de Caso 3: Data da última modificação

Todas as famílias entrevistadas fizeram modificações na sala, cozinha, dormitórios, banheiro e área de serviço; 93\% fizeram modificações no quintal e 64\% na garagem, como mostra o gráfico a seguir:

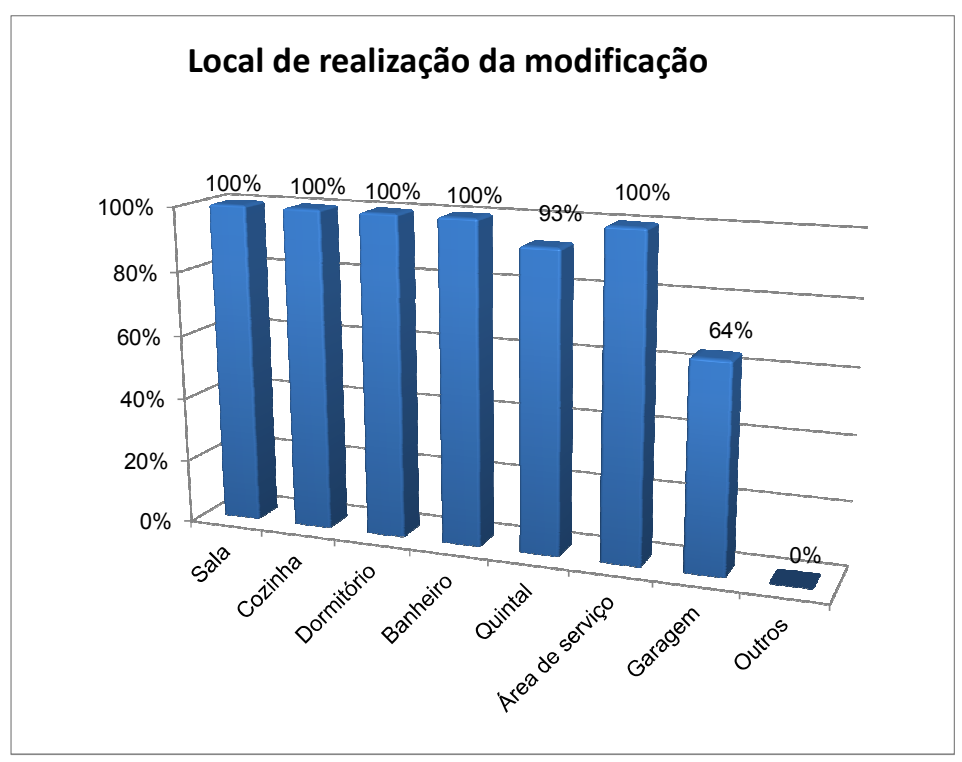

Gráfico 46 - Estudo de Caso 3: Local de realização das modificações

Todas as famílias entrevistadas colocaram piso e 93\% fizeram modificações na cobertura, pintura e azulejos, além de construírem cômodos novos, muros e portões. O gráfico 47, a seguir, apresenta todos os resultados dos itens modificados e a porcentagem de famílias que modificou cada um: 


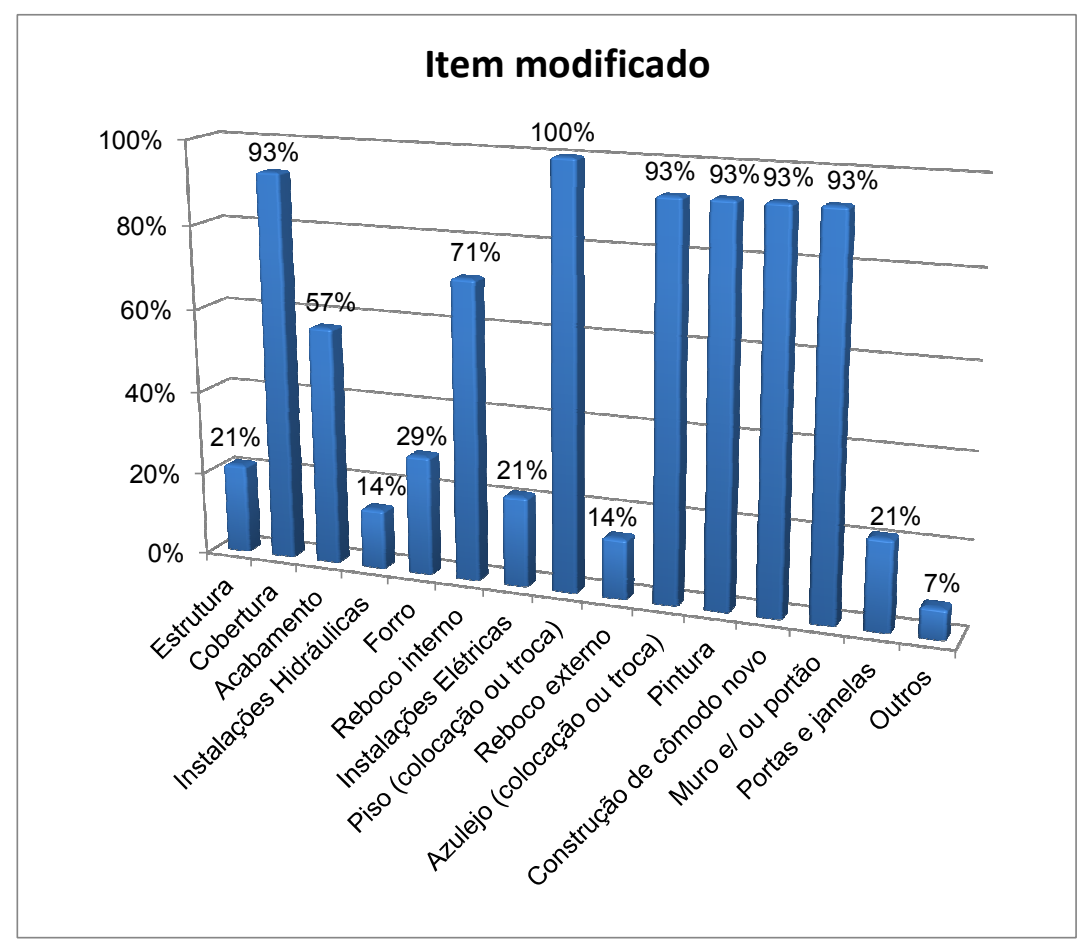

Gráfico 47 - Estudo de Caso 3: Itens modificados

Dentre os moradores entrevistados, apenas $14 \%$ afirmaram ter encontrado dificuldades técnicas para a realização das modificações. Estes moradores alegaram que as paredes eram "tortas", o que, em linguagem técnica, significa que estas paredes estavam desalinhadas e fora de prumo. Assim, eles dizem ter tido problemas para alinhá-las com as novas paredes. É importante registrar que as duas casas $(14 \%$ do total) onde foram relatadas dificuldades para a realização das modificações foram construídas pelo sistema de alvenaria estrutural com blocos de concreto.

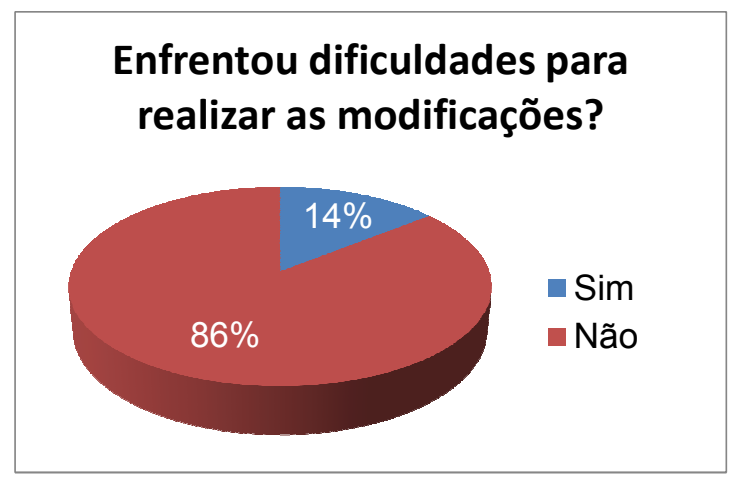

Gráfico 48 - Estudo de Caso 3: Dificuldades para realizar modificações 
Como apresentado no gráfico 38, a seguir, 64\% dos entrevistados afirmam ainda ter a intenção de realizar alguma modificação na casa futuramente.

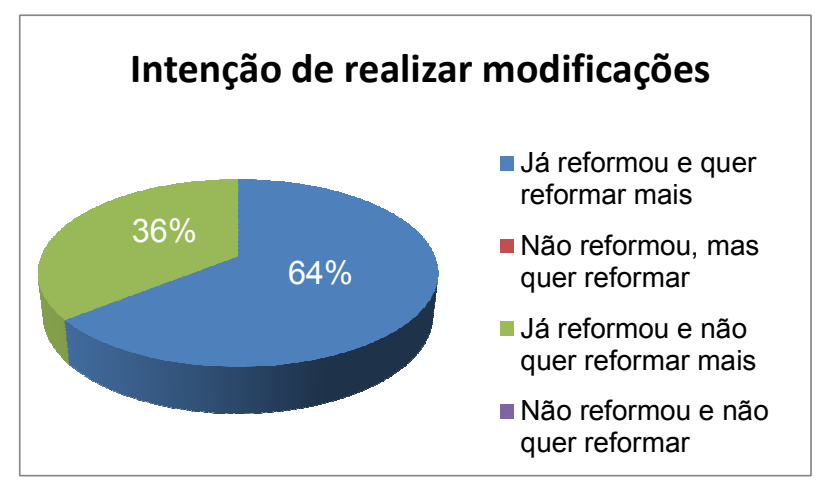

Gráfico 49 - Estudo de Caso 3: Intenção de modificar o imóvel

Dos moradores que pretendem realizar modificações, 33\% consideram que a reforma é urgente, como mostra o gráfico 50 :

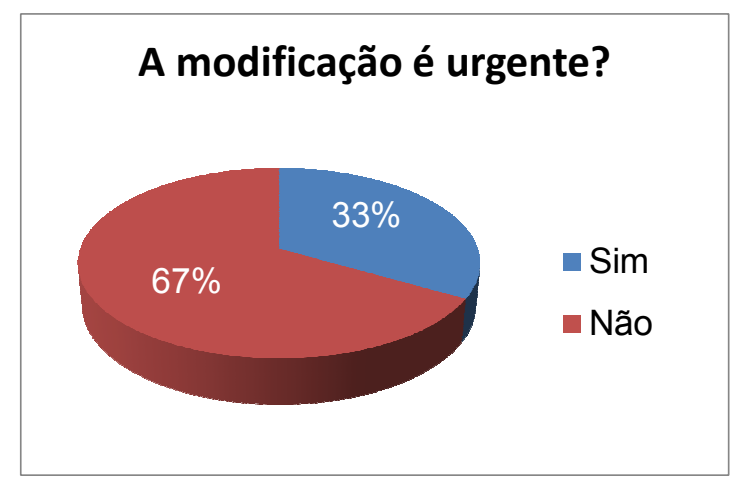

Gráfico 50 - Estudo de Caso 3: Urgência das modificações

O principal desejo dos moradores é a construção de um cômodo novo, item citado por $56 \%$ dos entrevistados, sendo que todos relatam a intenção de construir mais um dormitório. Também foi citada a intenção de fazer modificações na estrutura, cobertura, forro, revestimentos em geral, muros e portões. Os gráficos 40 e 41 apresentam detalhadamente as intenções dos moradores quanto à realização de novas modificações, destacando os ambientes a serem modificados e o tipo de serviço a ser executado, respectivamente. 


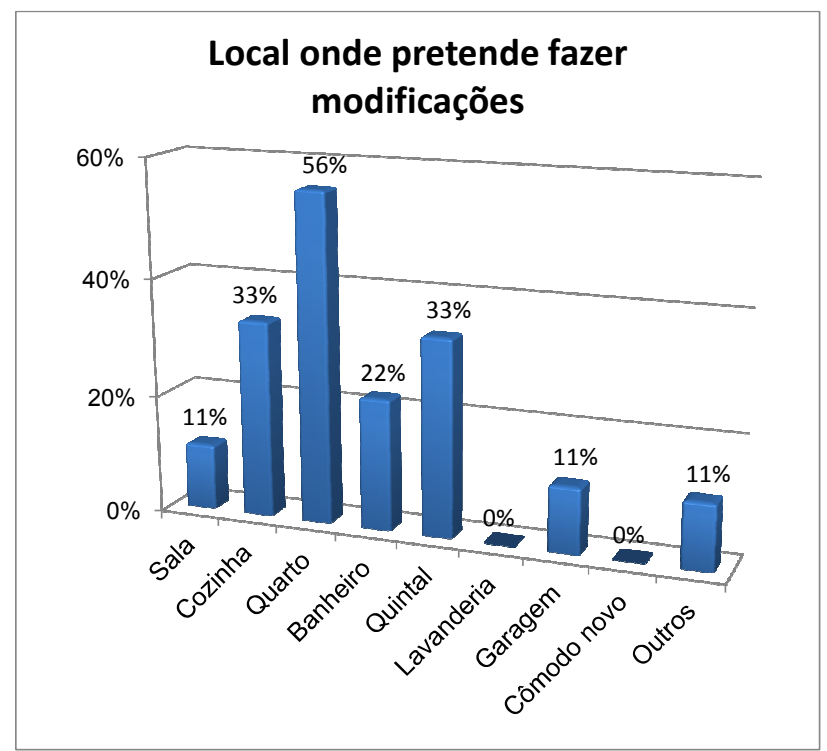

Gráfico 51 - Estudo de Caso 3: Locais que pretende modificar

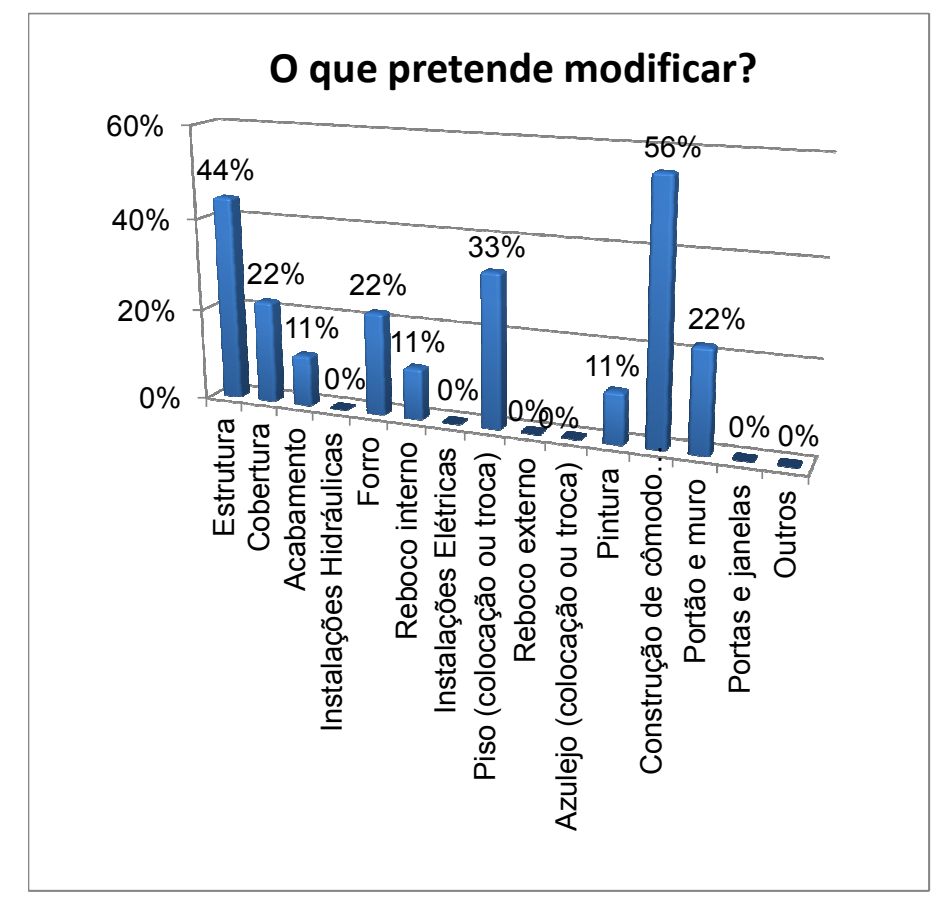

Gráfico 52 - Estudo de Caso 3: Serviços que pretende realizar

Para os moradores, o maior benefício das modificações realizadas ou intencionadas é a ampliação da casa, seguido pelo aumento da segurança e pela melhoria da aparência da residência, exatamente a mesma ordem de importância dada pelos moradores do Conjunto Habitacional Cunha "B". O gráfico 53, a seguir, 
apresenta os resultados completos dos benefícios das modificações citados pelos moradores:

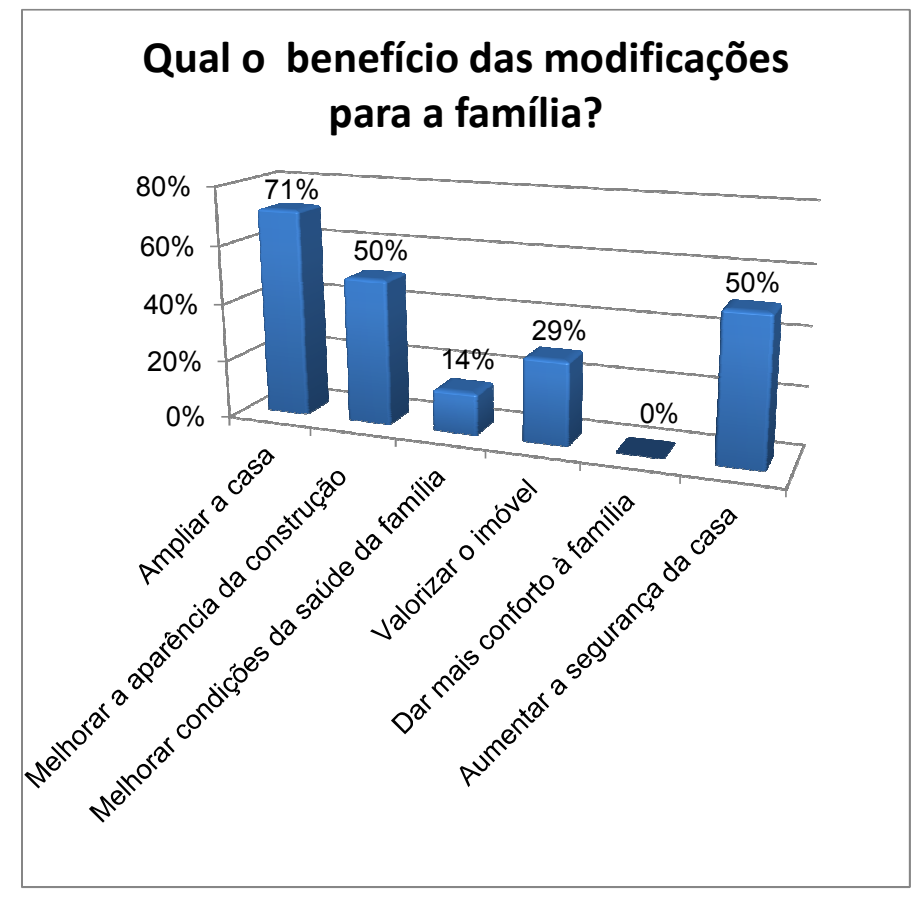

Gráfico 53 - Estudo de Caso 3: Benefício das modificações

\subsubsection{Apresentação e Análise dos Resultados da Avaliação Técnica}

A avaliação técnica dos imóveis foi realizada através de visita ao seu interior em companhia de um ou mais moradores.

Observou-se que a grande maioria das casas do conjunto habitacional conta com muros e portões, sendo que dentre as casas visitadas, apenas duas não têm muros na frente do lote. No primeiro caso, a frente do lote conta com portão metálico alto em quase toda a extensão e um pequeno trecho de muro no canto esquerdo, elemento que também está presente nas laterais e fundo do lote.

Já a outra casa conta com os muros laterais e de fundo construídos pelos vizinhos e com um portão de madeira baixo na frente do lote. 

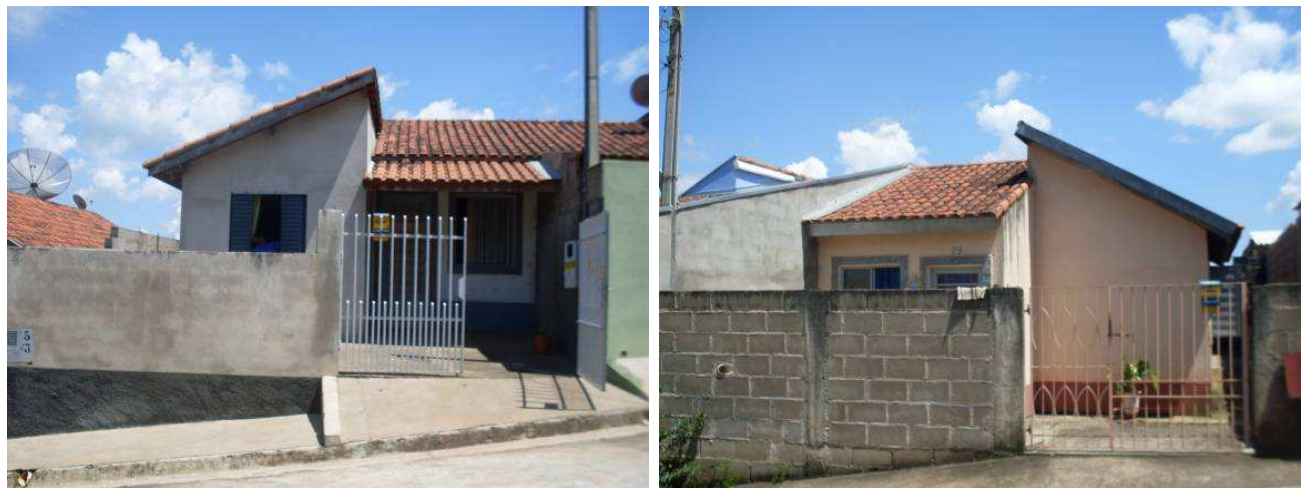

Figura 121 - Vista de fachadas com muros e portões

Fonte: a autora.

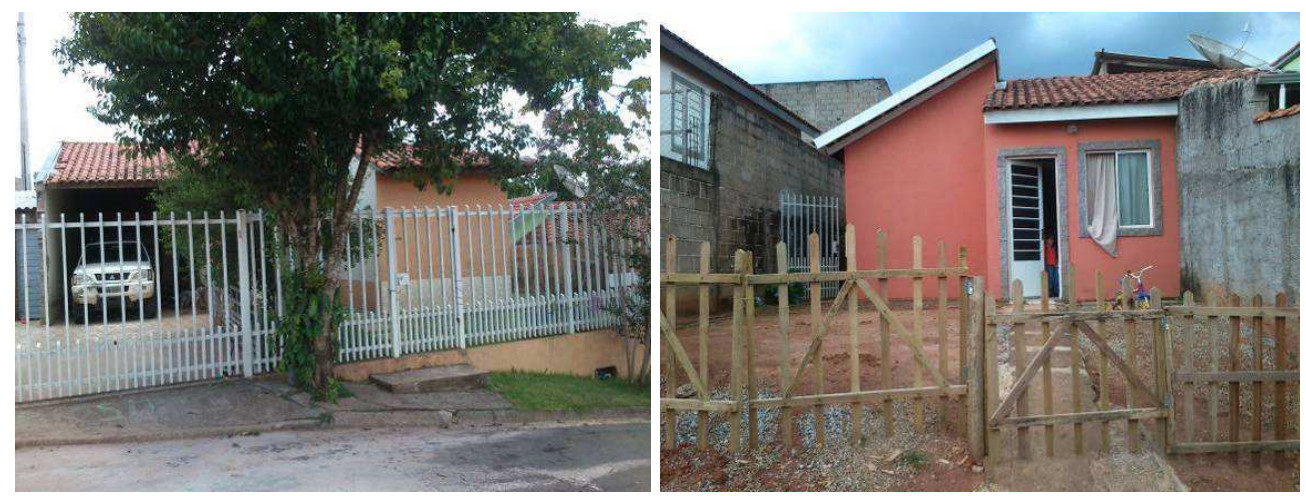

Figura 122 - Vista de fachadas só com portões

Fonte: a autora.

Dentre as 14 casas visitadas, 10 tiveram o lote totalmente cimentado, sendo que em duas delas também foi aplicado piso cerâmico em toda a área externa do lote. Outras três casas apresentam piso cimentado em parte do lote e as áreas restantes destinadas a jardins e hortas. Apenas uma casa manteve o terreno todo sem piso, apenas com terra, pedrisco e o caminho de placas de concreto do limite do lote até a entrada da casa, como pode ser visto na Figura 122.
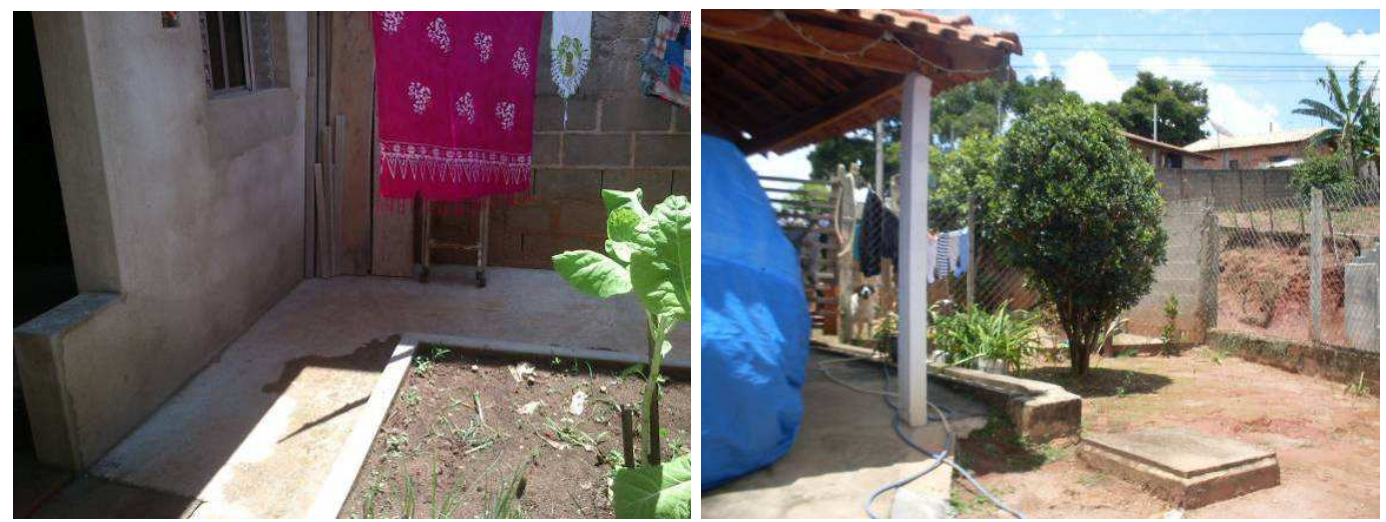

Figura 123 - Lotes com trechos cimentados na LGN07 e LGN14 Fonte: a autora. 
Há um desnível grande no aterro entre a área de lazer ao sul do empreendimento e as casas que fazem divisa de fundo com ela. Duas dessas casas não possuem muro nos fundos do lote e o barranco está desprotegido, porém, sem sinais aparentes de movimentação ou de riscos de desmoronamento.

Outra casa apresenta "afundamento" no piso cimentado do corredor na lateral do lote, com trincas e fissuras, o que sugere um possível recalque por acomodação do aterro. É importante salientar que existe um desnível entre este lote e o lote vizinho, o que ajuda a suportar a hipótese levantada.

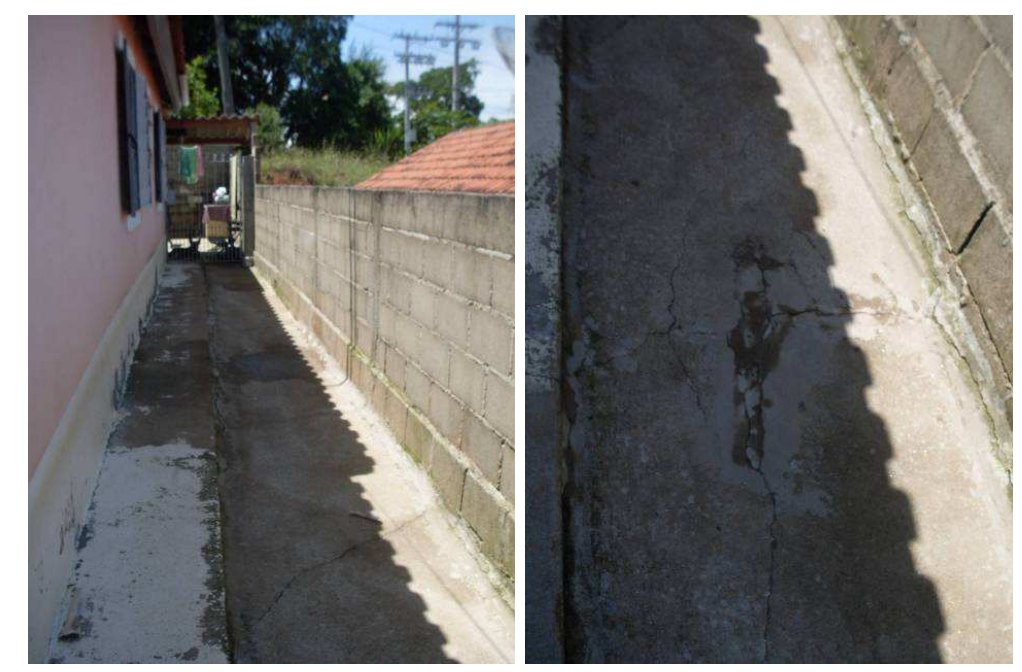

Figura 124 - Trincas e afundamento no piso do quintal da LGN11 Fonte: a autora.

Do outro lado da rua, uma das casas apresenta histórico de queda do muro e desbarrancamento do aterro justamente nessa região de desnível entre os lotes no corredor lateral, porém, este já foi reparado pelos moradores.

Uma moradora afirma que outra casa próxima também tem problemas de acomodação do aterro e diz que isto está causando trincas em sua casa, que é geminada a esta outra. Não foi possível visitar a casa com supostos problemas no aterro porque os moradores estavam viajando na ocasião da visita.

A fundação das unidades habitacionais é do tipo radier e encontram-se total ou parcialmente inacessíveis, sem sinais aparentes de anomalias. Em quatro das casas visitadas verificou-se a ocorrência de empoçamento de água sobre essas estruturas em alguns pontos, junto à base das paredes. 


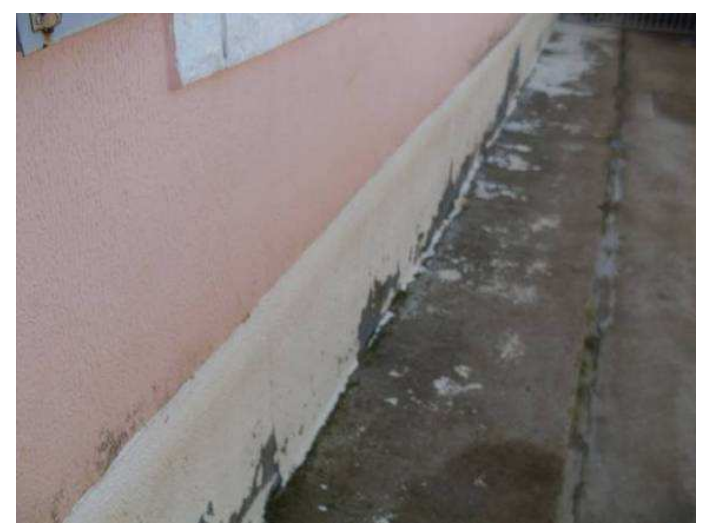

Figura 125 - Detalhe de radier com empoçamento na LGN11 Fonte: a autora.

Duas das casas visitadas apresentam, ainda, ampliações onde foram executadas fundações do tipo estacas escavadas moldadas in loco com pequena profundidade. Estas fundações estão inacessíveis, entretanto, não há sinais de patologias associadas a elas.

Conforme mencionado anteriormente, das 14 casas visitadas, 10 foram construídas através do processo construtivo de alvenaria estrutural com blocos de concreto, sendo que destas, 3 casas apresentam trincas e fissuras verticais, horizontais e mapeadas nas alvenarias. Duas dessas casas apresentam, ainda, sinais de umidade e infiltração nestes elementos.
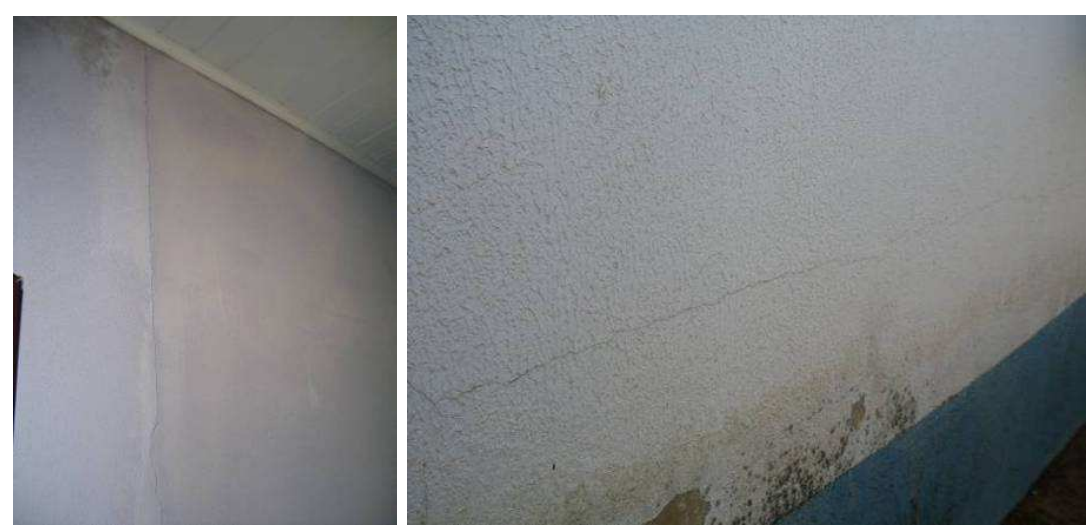

Figura 126 - Sinais de infiltração e trincas nas alvenarias da LGN01 Fonte: a autora. 

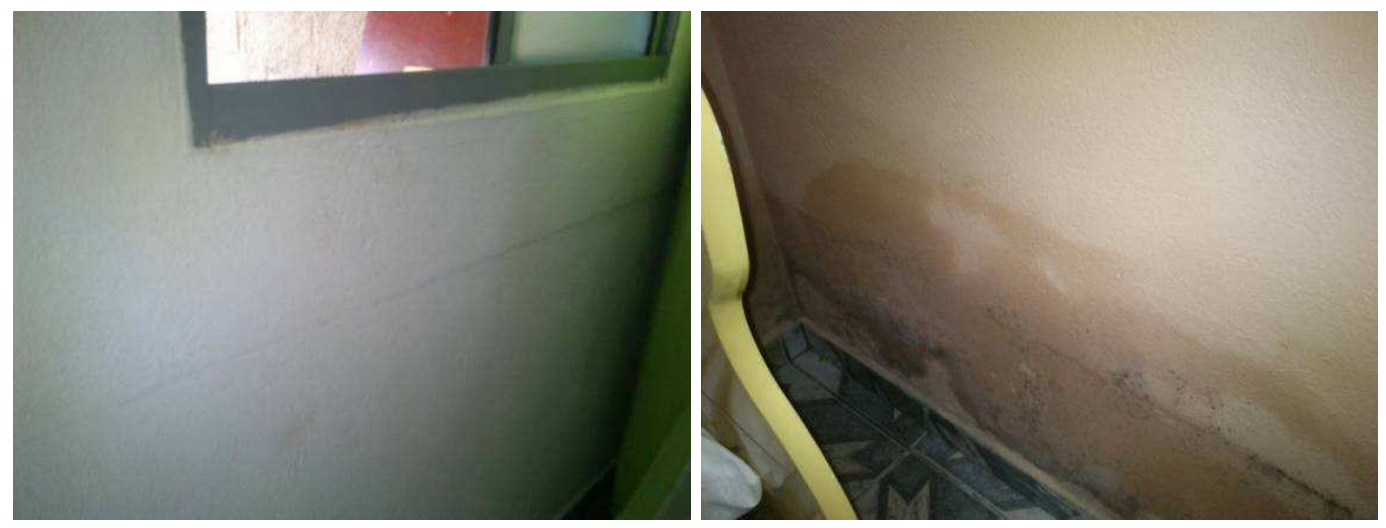

Figura 127 - Trinca horizontal e infiltração nas alvenarias da LGN06 Fonte: a autora.

As casas possuem lajes maciças de concreto em todos os cômodos, sendo que uma dessas casas apresenta sinais de umidade na laje e três delas apresentam lajes com falhas e imperfeições devidas, provavelmente, a falhas na desforma. Um dos moradores que trabalhou no mutirão afirmou que, na época da construção, as fôrmas das lajes foram alugadas por um prazo específico e que, em algumas casas, a desforma foi feita antes do tempo correto para atender ao prazo de devolução dessas fôrmas. O morador não soube especificar em quais casas isso ocorreu.
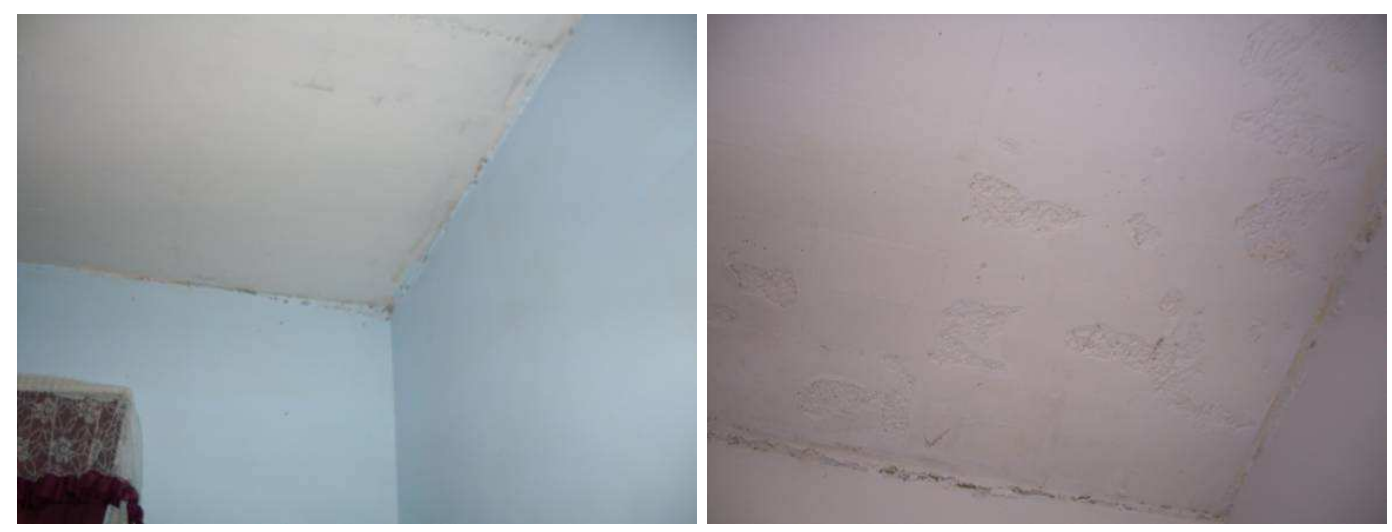

Figura 128 - Detalhes das falhas na superfície das lajes da LGN01

Fonte: a autora. 


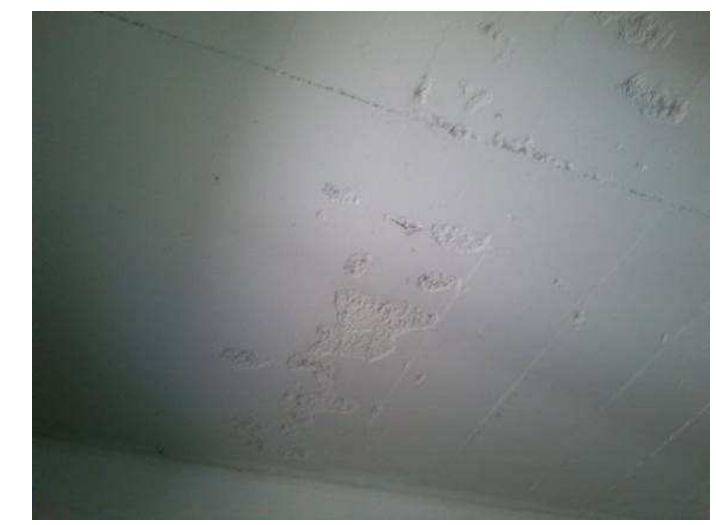

Figura 129 - Detalhe de falhas em laje da LGN06 Fonte: a autora.

Ainda dentre as 10 casas de alvenaria estrutural, 6 sofreram apenas ampliações horizontais, onde foram executadas alvenarias estruturais com blocos de concreto. Nestes casos, foram executados dormitórios e cozinhas, em geral sem a presença de laje. Em uma das casas, a cozinha teve seu fechamento realizado com um estrado de madeira e em outra, o dormitório foi executado isolado da casa original.
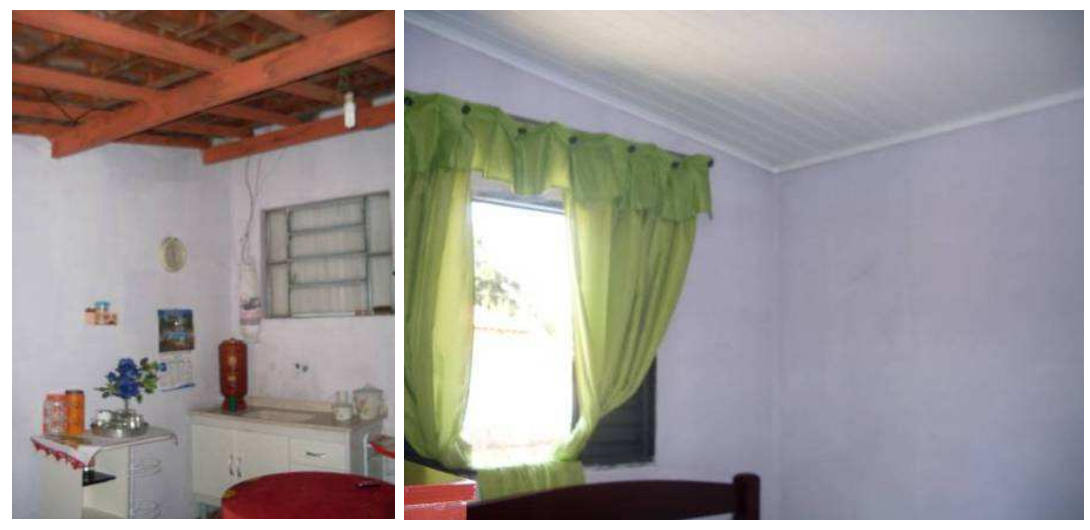

Figura 130 - Cozinha e dormitório executados na LGN01

Fonte: a autora. 


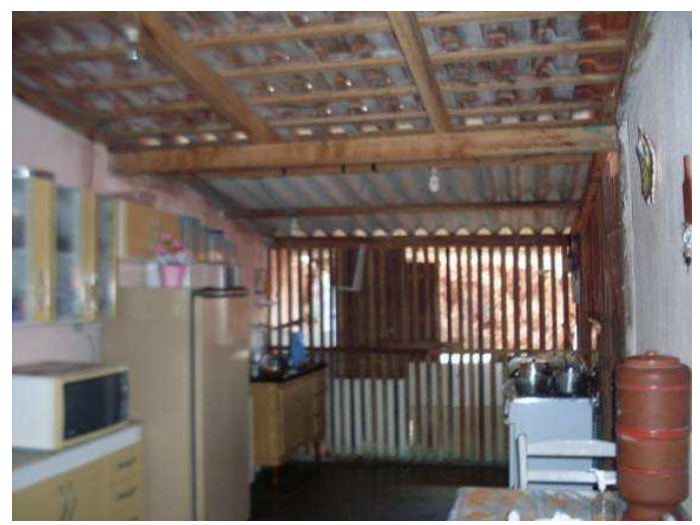

Figura 131 - Cozinha com fechamento de madeira e telhas mistas na LGN03 Fonte: a autora.

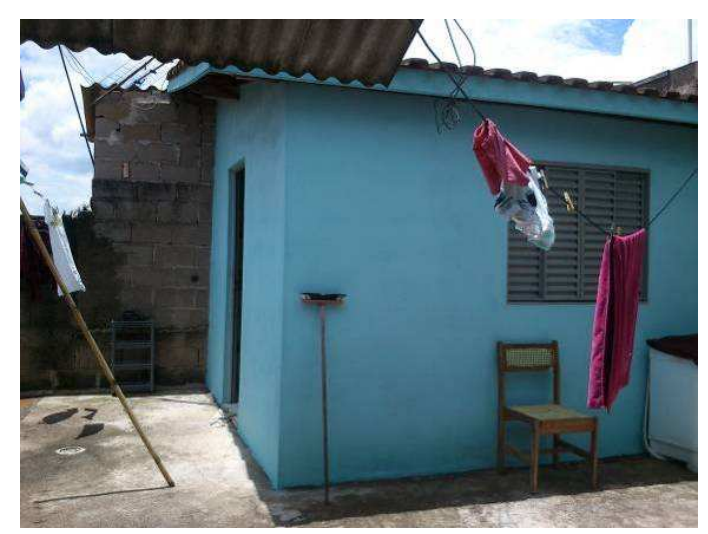

Figura 132 - Dormitório executado na LGN06, separado da casa original Fonte: a autora.

Outras 3 dessas casas sofreram ampliações verticais onde foram executadas estruturas de concreto e vedações com blocos de concreto, todas apresentando boas condições. Na casa LGN07, a ampliação ainda está em execução e o pavimento superior ainda não foi construído, estando apenas a laje preparada para recebê-lo. Já na LGN10, foi executada uma varanda sobre a garagem e a moradora afirma ter a intenção de executar ainda um dormitório e um banheiro sobre a área dos fundos do lote. No terceiro caso, o morador executou um dormitório e um banheiro nos fundos do lote, sobre a área de serviço. 

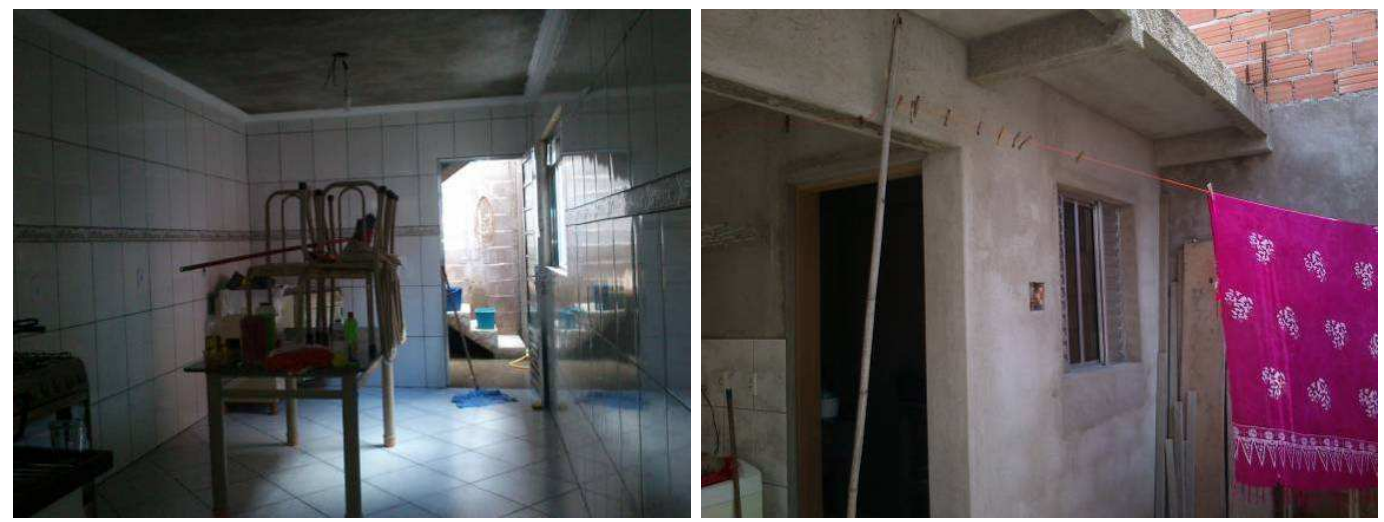

Figura 133 - Cozinha e dormitório em execução na LGN07 Fonte: a autora.

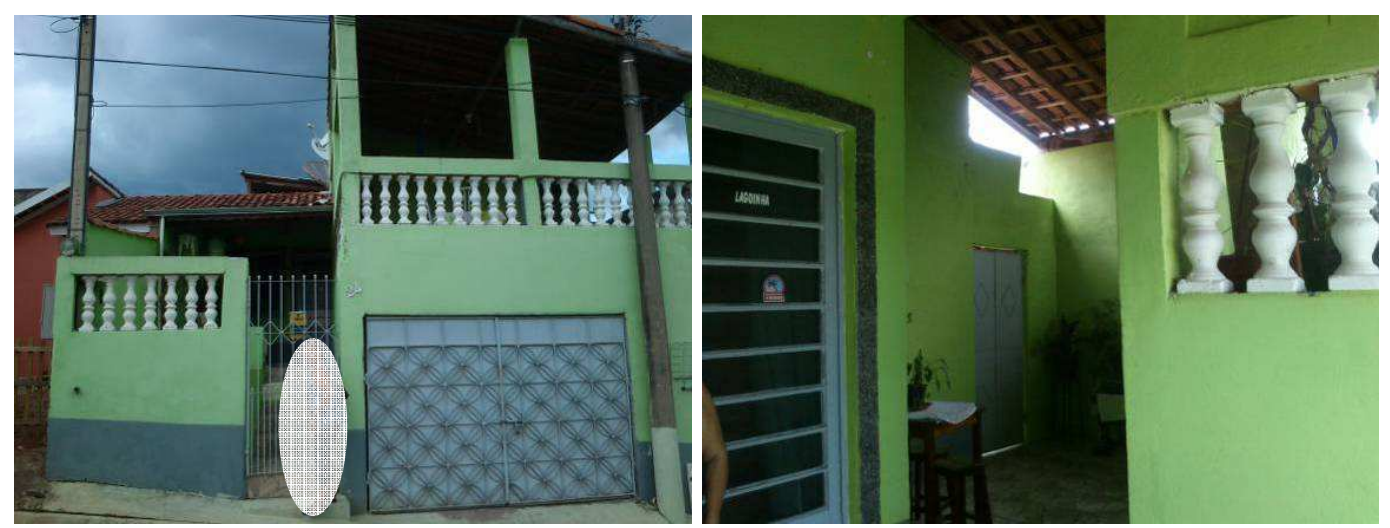

Figura 134 - Garagem e varanda executadas na LGN10

Fonte: a autora.

Outras 2 das 14 casas visitadas foram construídas pelo processo de estruturas metálicas com vedação em blocos de concreto e laje maciça de concreto. Em ambas as casas, as estruturas estão inacessíveis devido ao revestimento argamassado executado sobre elas, porém, não há sinais de patologias associados a elas.

Essas duas casas sofreram apenas ampliações horizontais, todas executadas com alvenaria de blocos de concreto e sem laje. As lajes e as alvenarias, tanto originais quanto novas, apresentam boas condições gerais, porém, há sinais de umidade nas paredes dos dormitórios da LGN11 e na laje da sala e nas paredes da cozinha nova da LGN12. 


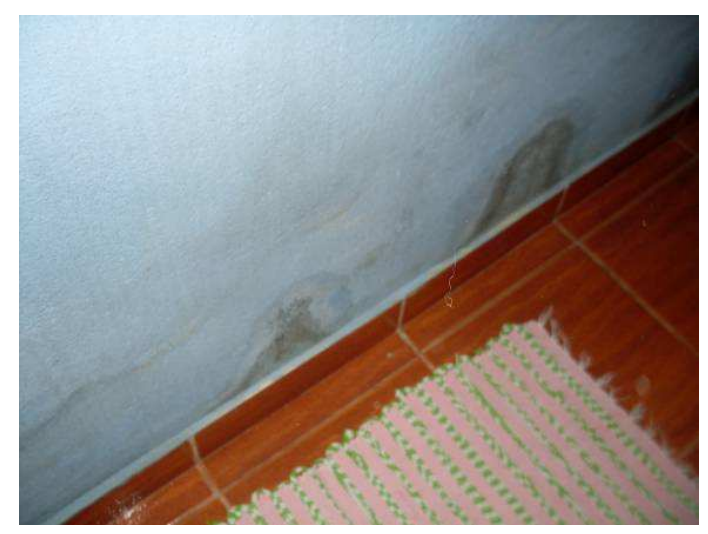

Figura 135 - Sinais de infiltração na parede do dormitório da LGN11 Fonte: a autora.
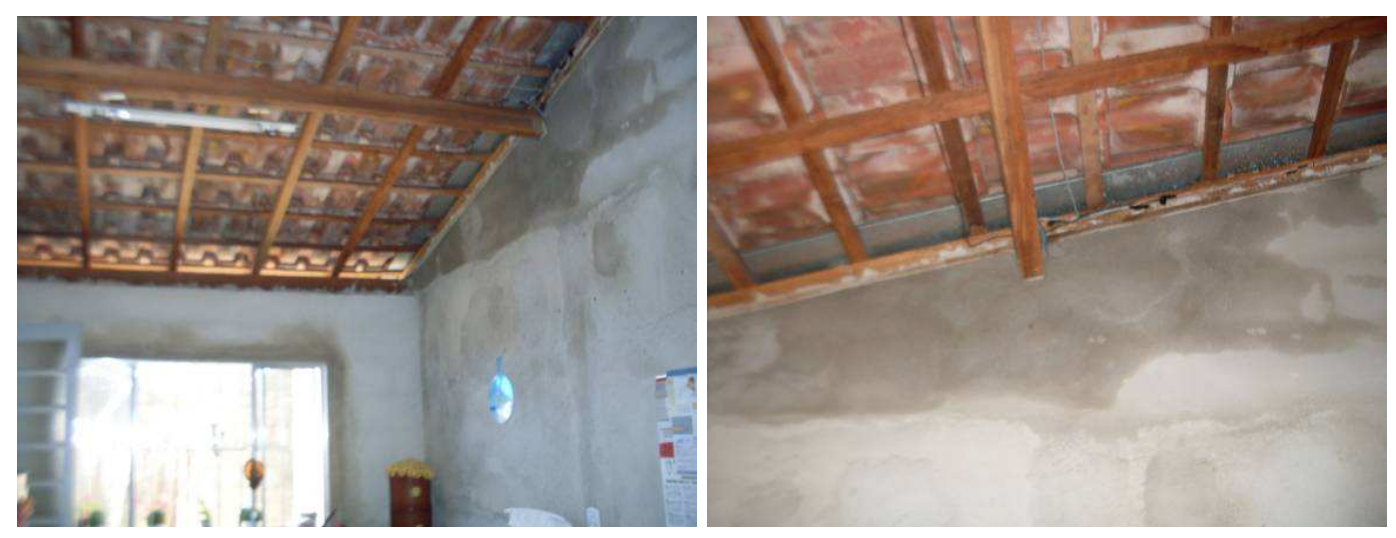

Figura 136 - Sinais de infiltração nas paredes da cozinha da LGN12 Fonte: a autora.

As duas casas restantes foram construídas pelo processo de paredes e lajes de concreto celular moldadas in loco, sendo que neste caso as paredes também cumprem as funções de estrutura e vedação. As paredes e lajes apresentam boas condições gerais, entretanto, uma das casas apresenta leves sinais de umidade na base das paredes voltadas para o corredor, o que pode ser atribuído ao empoçamento de água na superfície do radier.

As duas casas sofreram ampliação para construção de uma nova cozinha nos fundos da casa e em ambos os casos foi executada uma parede de blocos de concreto para fechar o espaço onde antes funcionava a área de serviço e transformá-lo na nova cozinha. Nas duas casas, há sinais de infiltração de água na alvenaria que divide as duas cozinhas, porém, com pouca intensidade. 


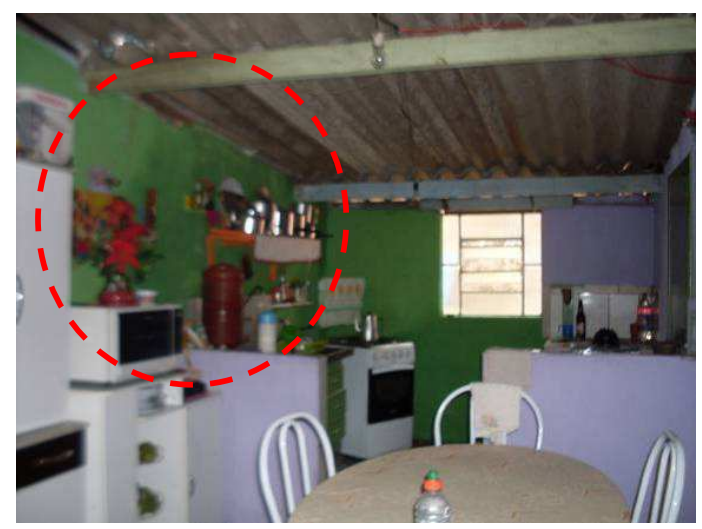

Figura 137 - Sinais de infiltração na alvenaria da cozinha da LGN14 Fonte: a autora.

Todas as casas, independentemente do sistema construtivo adotado para a construção da estrutura e da vedação, apresentam cobertura executada com estrutura metálica e telhas cerâmicas, sem sinais de anomalias. Uma das famílias trocou parte da estrutura metálica por estrutura de madeira e utilizou a estrutura retirada para fazer uma cobertura para a área de serviço e um banheiro novo no fundo dos lotes.

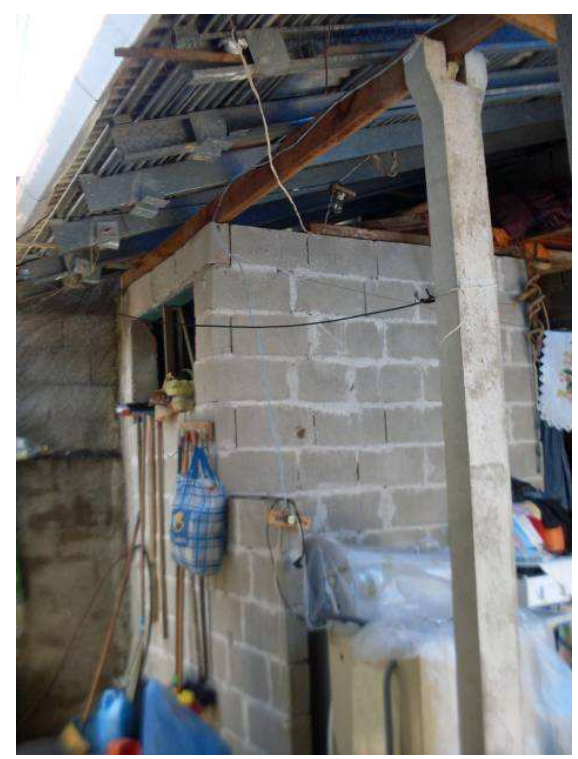

Figura 138 - Reutilização da estrutura metálica da cobertura da LGN12 Fonte: a autora.

Em todas as casas houve a execução de novas coberturas, seja para cobrir os cômodos novos, área de serviço, a garagem ou fazer uma varanda. Em geral, essas coberturas novas foram executadas com estrutura de madeira e telhas 
cerâmicas, sendo que em alguns lugares, de curta permanência e considerados menos nobres pelos moradores, foram utilizadas telhas de fibrocimento, como em áreas de serviço e garagens. Em uma das casas, a cobertura da nova cozinha foi feita com telhas cerâmicas e depois a família decidiu ampliar ainda mais essa cozinha e a nova cobertura foi feita com fibrocimento, sendo que a cozinha ficou com dois tipos de telhas diferentes (figura 131). Todas as coberturas apresentam bom estado de conservação.

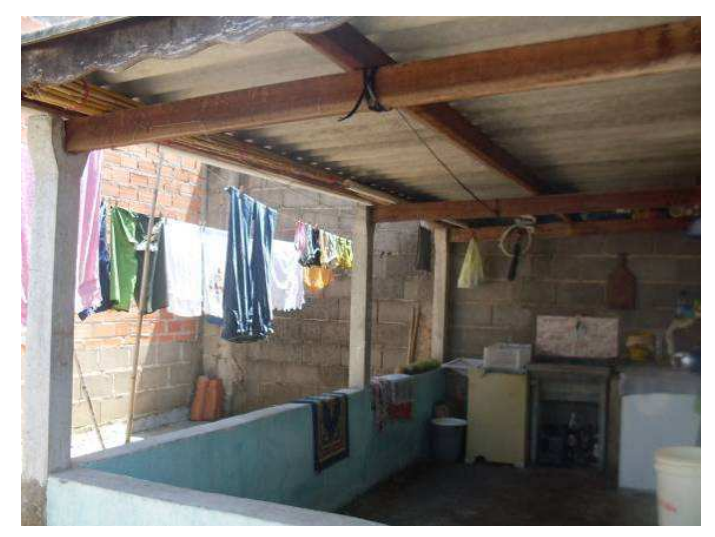

Figura 139 - Telhas de fibrocimento na cobertura da área de serviço da LGN01 Fonte: a autora.

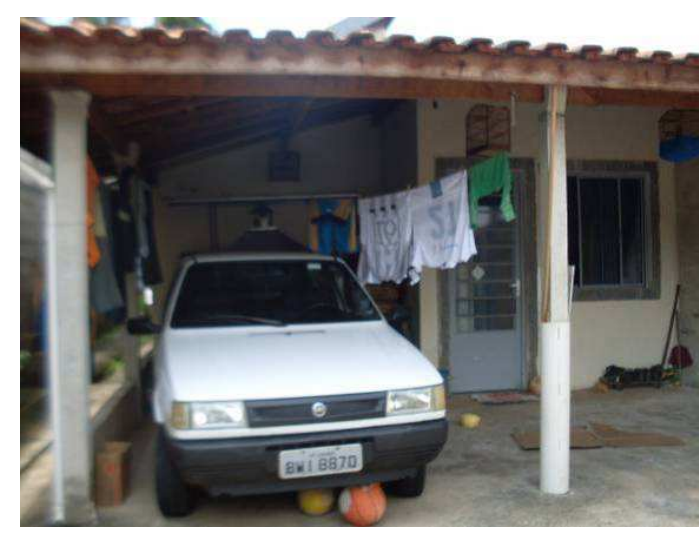

Figura 140 - Cobertura com telhas cerâmicas na garagem da LGN11 Fonte: a autora.

A execução de cômodos novos e coberturas de garagem, varandas e áreas de serviço acabaram por comprometer a iluminação e a ventilação de alguns ambientes, sendo que a metade das residências teve a iluminação classificada como inadequada. Os gráficos 54 e 55 mostram os percentuais de casas com a iluminação e ventilação consideradas inadequadas:

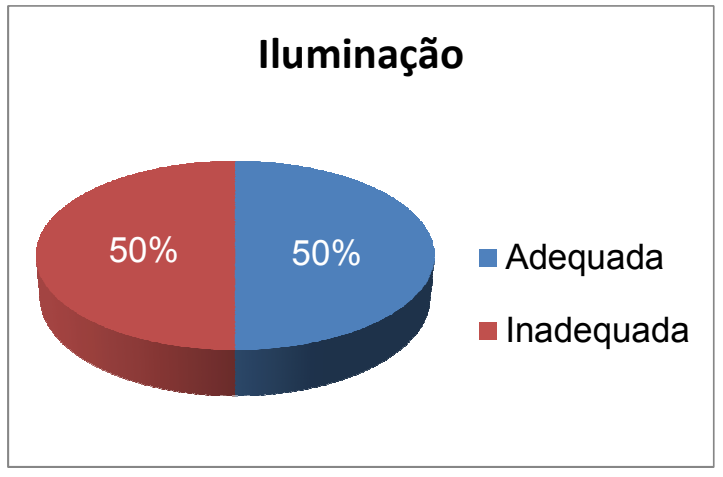

Gráfico 54 - Estudo de Caso 3: Avaliação técnica da iluminação

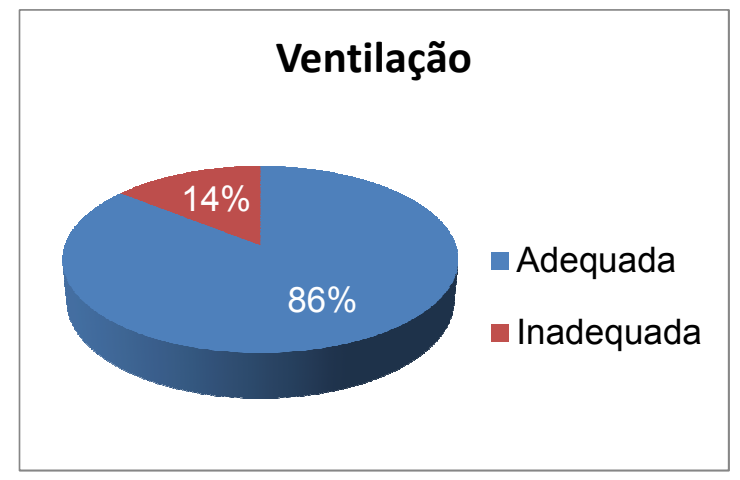

Gráfico 55 - Estudo de Caso 3: Avaliação técnica da ventilação 
Em duas casas foram aplicados forros, de PVC e de madeira, nos cômodos novos, que foram executados sem laje, e estes elementos apresentam boas condições.

As portas e janelas são de aço, com pintura em esmalte e vidros, em boas condições gerais. Apenas em uma casa a porta da sala apresenta princípio de corrosão na base e, na mesma casa, uma janela foi substituída porque, segundo os moradores, estava danificada. Nas ampliações foram utilizados tipos variados de esquadrias, sendo observadas esquadrias de aço, alumínio e madeira.

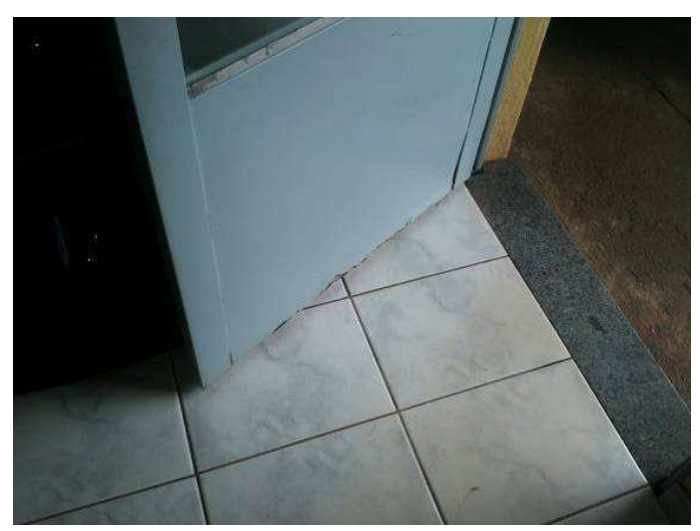

Figura 141 - Porta de aço da LGN07com início de corrosão na base Fonte: a autora.

As casas que possuem alvenaria de blocos de concreto, seja estrutural ou de vedação, apresentam revestimento argamassado e pintura, tanto nas faces internas quanto externas dessas paredes. As casas de paredes de concreto apresentam apenas pintura ou textura nas duas faces. Todas as casas apresentam azulejo nos banheiros, seja a meia altura ou até o teto. Algumas casas contam com duas ou três fiadas de azulejo apenas sobre a pia da cozinha e apenas uma casa apresenta azulejo na cozinha toda (figura 133). Os cômodos novos, em geral, apresentam reboco e a maioria conta também com pintura. Todos os revestimentos apresentam bom estado geral, porém, há pontos localizados danificados devido à presença de trincas e infiltrações de água. 


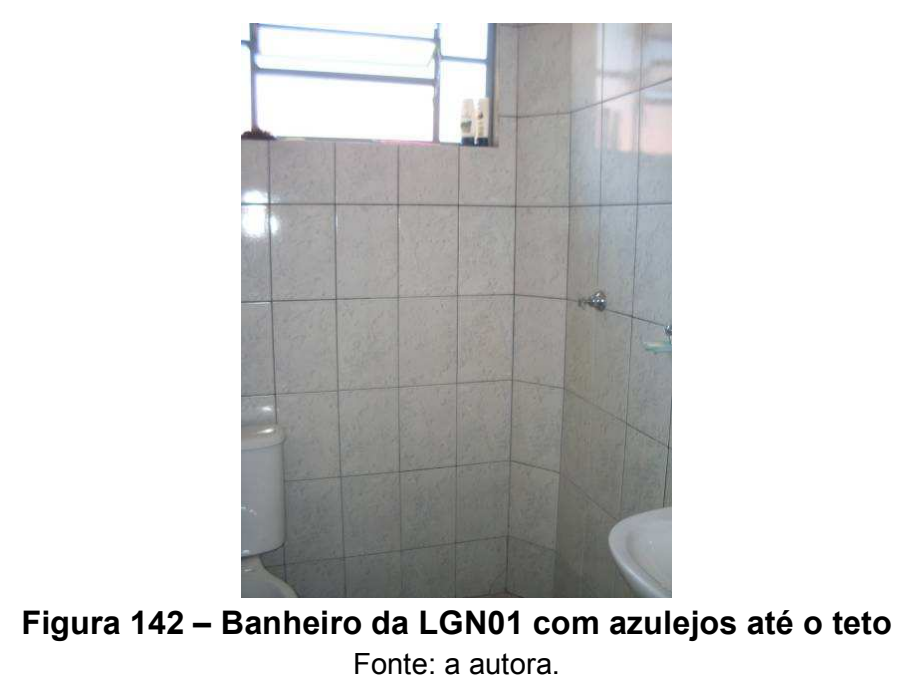

Todas as casas apresentam piso cerâmico nas áreas internas, sendo que duas delas apresentam piso cerâmico também no quintal e garagem. Apenas em uma das casas foi executado piso de cimento queimado na cozinha nova, mas a moradora afirma que tem a intenção de trocá-lo por piso cerâmico, e outra casa tem piso cimentado apenas na área de serviço. Todos os pisos apresentam boas condições de conservação.

De maneira geral, as instalações elétricas e hidráulicas apresentam boas condições. Em duas casas, uma de alvenaria estrutural e outra de parede de concreto, a instalação elétrica apresentou problemas com falta de fiação nos eletrodutos e caixas elétricas que não estavam corretamente fixadas às paredes. Em outra casa, de alvenaria estrutural, foi a instalação hidráulica que apresentou vazamentos e teve de ser reparada, exigindo a quebra das alvenarias.

A maioria das unidades teve as modificações classificadas como boas. O gráfico 56 a seguir apresenta os percentuais de classificação das modificações:

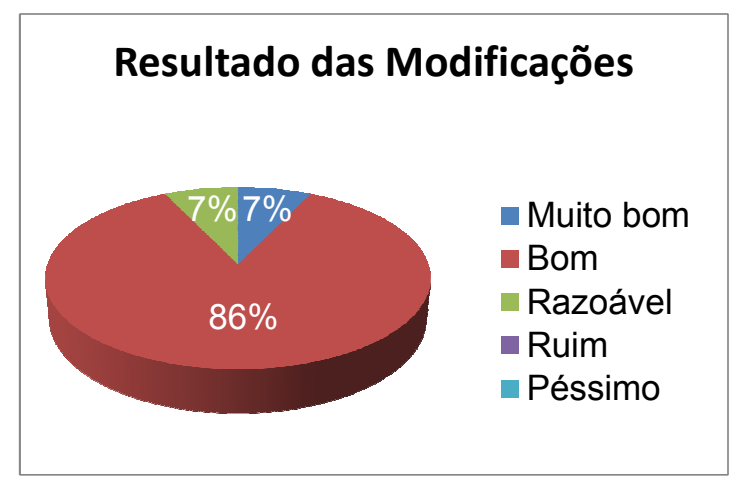

Gráfico 56 - Estudo de Caso 3: Avaliação das modificações realizadas 


\section{ANÁLISE E DISCUSSÃO DOS RESULTADOS GLOBAIS}

A realização de três estudos de caso diferentes permite fazer comparações e levantar discussões que vão além do sistema construtivo adotado. O trabalho de pesquisa realizado possibilita, também, levantar hipóteses e fazer considerações sobre o sistema de construção por mutirão, sobre a evolução das tipologias de unidades habitacionais fornecidas pela $\mathrm{CDHU}$ e, principalmente, sobre as modificações realizadas pelos usuários nessas unidades.

No primeiro estudo de caso, realizado no Conjunto Habitacional São Luiz do Paraitinga "C", foi analisado o sistema RBS de Concreto PVC. De modo geral, a patologia mais significativa encontrada nas casas visitadas nesse empreendimento foi a presença de umidade e infiltração em algumas casas, principalmente aquelas situadas na parte mais baixa da gleba e nas paredes de fachadas sul e sudoeste, onde se situam os dormitórios. Também foi observada umidade no teto dos banheiros de algumas unidades, provavelmente decorrente da umidade proveniente do vapor de água do chuveiro. Contribuiu, também, para essa situação o fato de algumas dessas famílias terem o hábito de manter as esquadrias basculantes dos banheiros fechadas todo o tempo, o que retém o vapor de água no interior do ambiente e resulta na sua condensação no teto, formando as manchas de umidade.

Já o segundo estudo de caso, realizado no Conjunto Habitacional Cunha "B", analisou o sistema construtivo de paredes de concreto celular moldadas in loco. Neste caso, o que mais chamou a atenção foi a presença de fissuras e trincas nas paredes de concreto, atribuídas, em um relatório técnico realizado na época da construção, à desforma inadequada e a falhas de posicionamento das armaduras. Embora estas trincas e fissuras tenham sido reparadas antes e depois da entrega para os moradores, verificou-se que elas reapareceram, total ou parcialmente.

O terceiro e último estudo de caso foi realizado no Conjunto Habitacional Lagoinha "A", onde o principal processo construtivo utilizado foi a alvenaria estrutural com blocos de concreto. Neste empreendimento foram realizadas, ainda, experiências com outros dois sistemas construtivos, o de paredes de concreto celular moldadas in loco e o de estrutura metálica com vedação de blocos de concreto. Algumas das casas de alvenaria estrutural apresentam fissuras e trincas, provavelmente devidas a recalques do aterro. Também foi encontrada infiltração no 
topo e base das paredes de algumas unidades. As casas de paredes de concreto apresentaram apenas um pouco de infiltração na base das paredes. Já as casas de estruturas metálicas e vedação com blocos de concreto apresentaram umidade nas paredes novas.

É interessante observar, no caso das unidades construídas pelo sistema de paredes de concreto celular moldadas in loco, que há uma grande diferença no resultado final nos dois empreendimentos, mesmo tendo sido utilizada a mesma tipologia habitacional. É visível que as casas de Lagoinha, construídas cerca de 2 a 3 anos antes, apresentam uma qualidade final superior à das casas de Cunha. Primeiramente, é possível constatar visualmente que o acabamento superficial do concreto é melhor. Além disso, o que mais chama a atenção é a ausência das fissuras e trincas nas casas de Lagoinha.

Diversos fatores podem ter contribuído para essas diferenças. Em primeiro lugar, foram utilizados sistemas de fôrmas diferentes, sendo que em Lagoinha foi utilizado o sistema de fôrmas plásticas e em Cunha adotou-se o sistema de placas compensadas de madeira reforçadas com estrutura metálica. Além disso, no caso de Lagoinha, por ser um teste da tecnologia envolvendo apenas duas unidades, houve um acompanhamento muito maior de todas as etapas e a participação de profissionais na execução, além dos mutirantes.

A utilização do sistema de construção por mutirão também pode ter influência sobre os resultados obtidos. Nessas condições, o treinamento da equipe é fundamental para garantir a qualidade e é preciso ter um controle e planejamento de obra muito eficazes para evitar falhas de execução. O que se viu no caso de Cunha, segundo relatos, foi a baixa participação dos mutirantes, com muitas faltas. $O$ fato de ser utilizada uma tecnologia diferente da que seria habitual para eles também dificultou o entendimento e, consequentemente, os resultados obtidos.

Já com relação às tipologias adotadas nos três empreendimentos, é importante salientar que os conjuntos habitacionais de Cunha e Lagoinha apresentam a mesma tipologia residencial, a TG23A da CDHU. Já em São Luiz do Paraitinga, foi adotada a tipologia TI33B para as casas térreas, alvo deste estudo.

É notável a evolução dos projetos ao longo do tempo, uma vez que as casas mais novas, de São Luiz do Paraitinga, são muito maiores e possuem uma série de itens inexistentes nos outros dois empreendimentos. É facilmente perceptível a 
melhoria na qualidade dos acabamentos dessas casas, além da presença de itens como aquecedores solares e área de serviço coberta. Isso tudo é fruto da reestruturação da política habitacional do Governo do Estado de São Paulo ocorrida entre os anos de 2007 e 2008.

Ainda assim, as duas tipologias estudadas foram alvo de críticas por parte dos moradores, sendo as principais delas referentes às cozinhas. No caso de São Luiz do Paraitinga, a reclamação comum foi com relação ao tamanho desse ambiente, considerado muito pequeno pelos moradores. A solução adotada pela maioria deles foi a de construir uma nova área de serviço e utilizar o espaço originalmente destinado a ela como uma extensão da cozinha. Do ponto de vista funcional, essa solução não é a mais adequada, uma vez que a cozinha ficou dividida por uma parede, o que dificulta a movimentação durante as atividades diárias.

Já no caso da tipologia TG23A, adotada em Cunha e Lagoinha, a reclamação se deve ao fato de não haver uma separação física entre a cozinha e a sala, o que incomoda a grande maioria dos moradores.

De modo geral, é possível afirmar que as duas tipologias apresentam cozinhas incompatíveis com os padrões culturais da região, que apresenta uma culinária local bastante rica e baseada em pratos pesados e gordurosos, que exigem um preparo mais demorado e cheio de etapas. A preparação desses alimentos também gera fumaça e gordura que, segundo os moradores, se espalha pela casa inteira, uma vez que não há divisões. Além disso, é costume na região, assim como em outras regiões do interior, receber os amigos e familiares na cozinha para tomar um café e conversar, o que não é possível com o tamanho reduzido desses ambientes, principalmente nas casas de São Luiz do Paraitinga.

Observou-se, também, principalmente na cidade de Cunha, as tradições de cozinhar em fogões a lenha e de torrar e moer o café em casa, observada em algumas das casas visitadas. Nessas casas, as famílias construíram fogões à lenha nos fundos da casa, onde também torram e moem o café em espaços divididos com a área de serviço e área de lazer da família. A pluralidade de atividades distintas sendo realizadas no mesmo espaço também gera dificuldades e riscos à saúde e segurança dos moradores, em especial às crianças. 
Com relação às modificações realizadas pelos moradores nos três estudos de caso, percebe-se claramente a necessidade de aumentar a segurança e privacidade através da construção de muros e portões, que não foram entregues com as casas em nenhum dos empreendimentos. Essa atitude também demonstra, de forma não tão explícita, a necessidade dessas famílias de demarcar o seu território. Antes moradores de áreas de risco e de habitações inadequadas, na maioria dos casos irregulares e sem garantias legais de propriedade, eles agora enxergam, instintivamente, a necessidade de garantir a posse da casa própria e o fazem através da demarcação do seu espaço.

Da mesma forma, observou-se em muitas casas, principalmente nos dois empreendimentos mais antigos, a tendência e a vontade dos moradores em ocupar todo o lote. É possível que essa atitude represente uma repetição de comportamento, uma vez que em áreas invadidas, onde não há lotes definidos, quanto mais área se ocupa, mais área se tem. Assim, essas pessoas repetem, sem perceber, esse comportamento e fazem ampliações desnecessárias e acabam por comprometer a funcionalidade dos ambientes.

Um exemplo disso foi a afirmação de uma moradora de Cunha que diz ter a intenção de construir mais um cômodo no lote, já quase todo ocupado, sem saber ainda qual será a utilidade desse novo ambiente. $E$ ela não foi a única. Outros moradores, nos três empreendimentos, afirmaram também ter a intenção de ampliar a casa, mesmo tendo espaço suficiente para a família.

Também em Cunha, uma das famílias executou novos cômodos e coberturas de forma que todo o lote ficou ocupado, cercado por paredes, muros altos e um portão de ferro. Embora a família tenha utilizado telhas translúcidas no corredor, a iluminação natural e a ventilação da casa como um todo ficaram bastante prejudicadas.

Em Lagoinha, temos o caso de uma família composta de três pessoas, o casal e uma criança, que construiu uma nova cozinha e outro dormitório, mesmo afirmando não ter a intenção de ter mais filhos.

Nos empreendimentos de Cunha e Lagoinha, verificou-se, ainda, a realização de ampliações verticais visando aproveitar ainda mais o terreno. Essas ampliações, executadas com técnicas inadequadas e sem um olhar arquitetônico, muitas vezes também comprometem a iluminação e ventilação de alguns ambientes, além de 
representar um risco à durabilidade e resistência da estrutura, que não foi projetada para suportar tais esforços.

De modo geral, a realização de modificações é tida como algo natural e a maior ou menor facilidade de execução parece estar muito mais relacionada à tipologia do que ao sistema construtivo empregado.

A tipologia TG23A, já projetada pensando em ampliações, se mostrou muito mais propícia à realização de modificações do que a TI33B, primeiro porque a área inicial é maior e em segundo lugar porque a localização e as dimensões das ampliações são quase que intuitivas, como mostra a figura 143 .

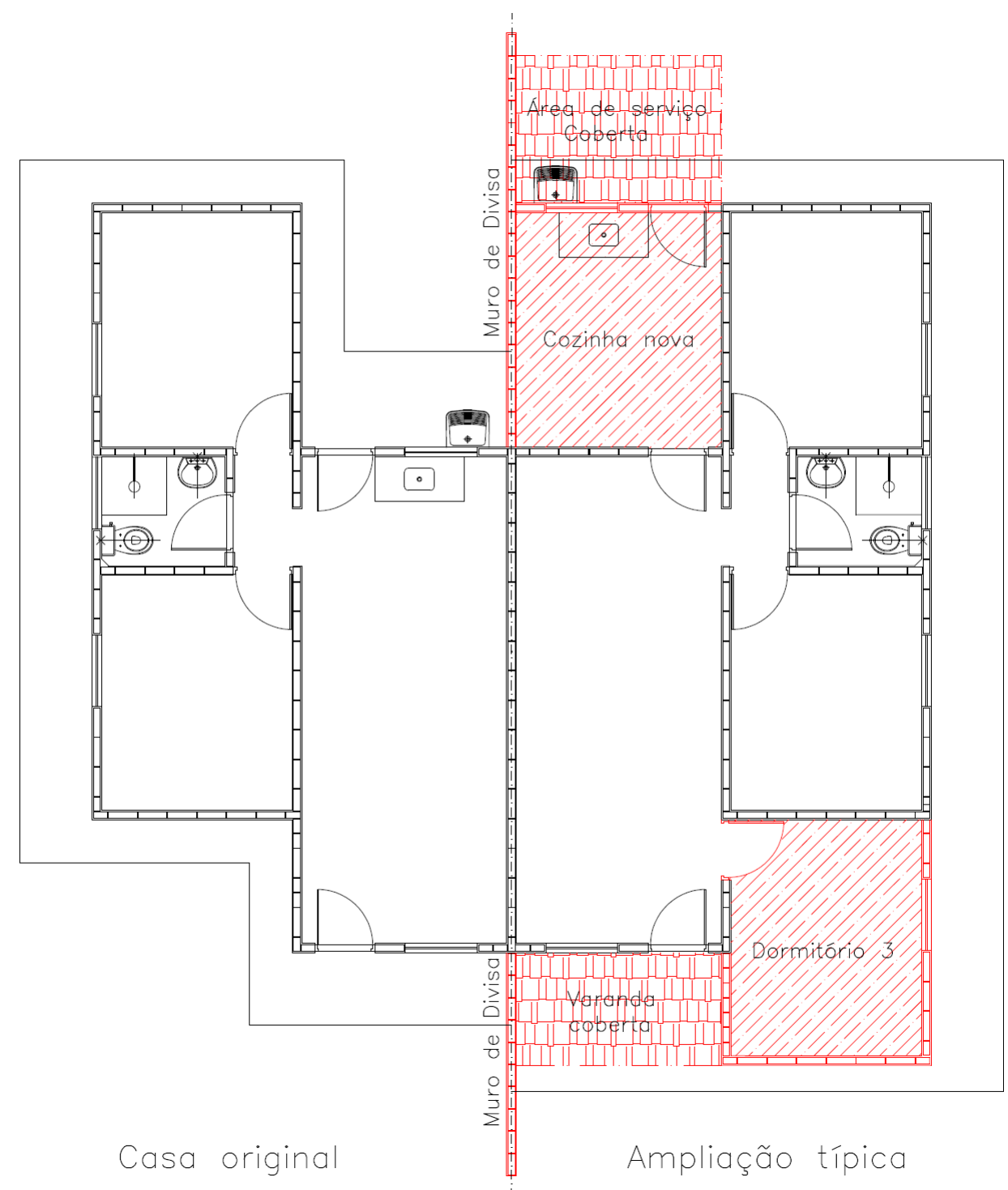

Figura 143 - Modificações típicas nas unidades da tipologia TG23A Fonte: a autora. 


\section{CONSIDERAÇÕES FINAIS}

A questão da habitação de interesse social é ainda muito complexa e vem sendo discutida há anos no Brasil. A relação entre custo da unidade habitacional e satisfação dos moradores é algo difícil de equacionar, sendo que diversas experiências já foram realizadas para tentar melhorar essa relação.

Para que os governos possam garantir o amplo atendimento no fornecimento de habitações de interesse social, o custo desses imóveis não pode ser muito elevado, correndo-se o risco de não atender a toda a população que necessita deles. Não se pode, no entanto, reduzir esses custos de tal forma que a qualidade $e$ funcionalidade das habitações sejam afetadas. Assim, o uso de materiais sem qualidade e a entrega de moradias incompletas não são soluções para esse impasse, pois assim se estará gastando recursos à toa, uma vez que o morador terá que arcar, futuramente, com os custos de finalização e manutenção do imóvel.

A satisfação do usuário é algo subjetivo, que pode mudar com o tempo e que é difícil de ser classificada ou quantificada. Muitas vezes, a comparação com a moradia anterior leva os usuários a uma avaliação superestimada da nova residência, avaliação esta que pode ir mudando conforme ele passa a interagir com o novo imóvel e vai esquecendo as dificuldades passadas anteriormente.

$\mathrm{O}$ uso de sistemas construtivos racionalizados e industrializados tem como finalidade justamente a redução dos custos de forma que a qualidade não seja prejudicada, fornecendo casas melhores por um custo menor ou pelo menos equivalente ao custo das casas construídas com sistemas tradicionais.

O estudo aqui apresentado permite concluir que os três sistemas são viáveis para habitações de interesse social, desde que, como em todos os sistemas construtivos, sejam tomados alguns cuidados nas fases de projeto e execução.

De modo geral, as patologias encontradas são decorrentes de falhas executivas e, tendo sido esses empreendimentos construídos já há algum tempo, diversas melhorias já foram inseridas nesses processos construtivos.

No caso das paredes de concreto moldadas in loco, já foram desenvolvidos novos sistemas de fôrmas, com materiais e sistemas de encaixe diferentes, e os procedimentos de cálculo estrutural e posicionamento de armaduras já foram muito discutidos e melhorados. Além disso, as instalações elétricas e hidráulicas ganharam 
peças destinadas especificamente ao processo, o que evita, por exemplo, que as caixas elétricas saiam da sua posição, que sofram deformações por pressão do concreto ou que sejam preenchidas com ele durante a concretagem.

Além disso, tanto nos processos de alvenaria estrutural com blocos de concreto quanto de paredes de concreto moldadas in loco, não se utiliza mais as instalações hidráulicas embutidas nas paredes, sendo dada preferência às instalações verticais aparentes ou protegidas por carenagens e a passagem de tubulações horizontais sobre forros ou lajes. Dessa forma, reduz-se a criação de pontos frágeis nas paredes estruturais e evita-se quebrar essas estruturas para eventuais reparos.

Com relação às modificações promovidas pelos usuários, o estudo mostrou, em uma população razoavelmente heterogênea, padrões de comportamento muito semelhantes e independentes do sistema construtivo utilizado.

As modificações realizadas evidenciam a necessidade de aumentar a segurança, privacidade e conforto da família, além de ampliar o espaço das unidades habitacionais.

A principal influência do sistema construtivo na realização dessas modificações é no caso da realização de ampliações, quando é preciso fazer a ligação da estrutura original com a nova estrutura. Nesses casos, nem sempre é possível utilizar o mesmo processo construtivo e, mesmo quando é possível, essa tarefa não é de fácil execução.

Nestas situações, é comum que apareça uma trinca ou fissura na junta a prumo vertical criada entre a parede nova e a parede antiga. No caso das paredes executadas com alvenaria de blocos de concreto, por exemplo, mesmo as ampliações tendo sido realizadas com o mesmo material, há a presença dessas trincas, pois não há travamento das fiadas de blocos das duas paredes.

O ideal seria, portanto, que os moradores recebessem um manual e um projeto para realização dessas ampliações indicando, principalmente, como se dá a ligação entre as paredes executadas e os diversos sistemas possíveis para a realização das ampliações, inclusive com especificação de materiais. Além disso, esse manual deve conter as informações necessárias para manutenção do imóvel.

Nos empreendimentos mais novos, como o Conjunto Habitacional São Luiz do Paraitinga "C", a CDHU já está adotando, como parte das melhorias implantadas 
com a reestruturação da política habitacional do Governo do Estado de São Paulo, a entrega do Manual do Usuário como um padrão.

É preciso, no entanto, que este manual contenha não só orientações gerais, mas a especificação clara dos materiais e procedimentos a serem adotados em caso de realização de ampliações. Para tanto, é necessário que as tipologias adotadas já apresentem as opções de ampliações.

Essas tipologias devem considerar que as pessoas e as famílias são diferentes e têm necessidades e sonhos também diferentes. Assim, é preciso implantar tipologias que tenham flexibilidade de uso e permitam maiores opções para as famílias.

Entende-se, portanto, que a realização de pesquisas que levantem as necessidades das famílias é de fundamental importância para a concepção dessas tipologias, assim como o estudo e aprimoramento dos sistemas construtivos pode gerar novas soluções para antigos problemas.

Esta pesquisa possibilitou alcançar um maior conhecimento sobre sistemas construtivos para habitação de interesse social e sobre as modificações realizadas pelos usuários dessas habitações. No entanto, o estudo apresentou algumas limitações, como a dificuldade em se determinar exatamente todas as características do sistema construtivo utilizado tanto na construção original quanto nas modificações realizadas pelos moradores, principalmente no terceiro estudo de caso, devido ao tempo decorrido desde a sua construção. Outra limitação foi quanto à amostra de casas visitadas que, devido ao tempo e aos recursos disponíveis, não pôde abranger todas as unidades habitacionais dos três empreendimentos.

Assim, embora os resultados obtidos sejam considerados bons, entende-se que mais estudos são necessários para se chegar a resultados mais específicos.

Como sugestão para a realização de novos estudos, propõe-se o acompanhamento de um ou mais empreendimentos, executados com diversos sistemas construtivos, desde a fase de concepção até o pós-obra. Dessa forma, entende-se que será possível obter todas as informações referentes ao sistema construtivo utilizado e ao histórico de execução do empreendimento. Além disso, seria interessante a realização de acompanhamentos anuais para compreender as prioridades dos moradores e medir a progressão da realização de modificações. 


\section{REFERÊNCIAS}

ABIKO, A. K.; CARDOSO, L. R. A.; GONÇALVES, O. M.; HAGA, H. C. R.; INOUYE, K. P.; BARBOSA, A. L. S. F. O futuro da indústria da construção civil: produção habitacional. Brasília: MDIC - Ministério do Desenvolvimento, Indústria e Comércio Exterior, 2005. v. 1. 122 p.

ANAMACO \& LATIN PANEL. Tendências Latin Panel - Para onde caminha o consumidor? 2008. Disponível em: <http://www.anamaco.com.br/resumo_ dados_materiais.ppt>. Acesso em: 18 mar 2010.

ANDERY, P. R. P.; ARANTES, E. M.; VIEIRA, M. P. C. Experiências em Torno à Implementação de Sistemas de Gestão da Qualidade em Empresas de Projeto. In: IV Workshop Brasileiro de Gestão do Processo de Projeto na Construção de Edifícios, 2004. Anais..., Rio de Janeiro, 2004.

ASSOCIAÇÃO BRASILEIRA DE CIMENTO PORTLAND (ABCP). Manual Técnico para Implementação - Habitação 1.0 ® Bairro Saudável. População Saudável. São Paulo, Associação Brasileira de Cimento Portland, São Paulo, 2002. 88 p.

Paredes de concreto celular moldadas in loco: Guia de Produção para Edificações Térreas. FICEM (Federación Interamericana del Cemento), Cidade do Panamá, 2007.

ASSOCIAÇÃO BRASILEIRA DE NORMAS TÉCNICAS (ABNT). NBR 12645: Execução de paredes de concreto celular espumoso moldadas no local. Rio de Janeiro, 1992.

NBR 15961: Alvenaria estrutural - Blocos de Concreto. Rio de Janeiro, 2011.

NBR 6136: Bloco vazado de concreto simples para alvenaria estrutural: procedimento. Rio de Janeiro, 2007.

BARROS, M. M. S. B. Metodologia para implantação de tecnologia construtiva racionalizada na produção de edifícios. São Paulo, 1996. Tese (Doutorado) Escola Politécnica, Universidade de São Paulo.

BARROS, M. M. S. B. O processo de produção das alvenarias racionalizadas. In: seminário de tecnologia e gestão da produção de edifícios: vedações verticais, São Paulo, 1998. Anais. São Paulo: PCC/TGP, 1998. p. 21 - 48. 
BAUER, R. J. F. Patologias em Alvenaria Estrutural de Blocos Vazados de Concreto. Caderno técnico alvenaria estrutural, v. 5, p. 33-38, 2006. Disponível em: http://www.mandarim.com.br/download.asp?arquivo=2052008144143.pdf. Acesso em: 12 jan 2013.

BERGAMO, G. São Luiz do Paraitinga sofre com as chuvas do início de ano. Veja SP. São Paulo, 13 Jan. 2010. Disponível em: <http://vejasp.abril.com.br/revista/edicao-2147/sao-luiz-do-paraitinga-sofre-comas-chuvas-do-inicio-de-ano>. Acesso em: 08 nov 2011.

BOIN, A. C. Manual de edificações em concreto celular: Teoria e Prática. ABCP - Associação Brasileira de Cimento Portland, São Paulo, 2003. (Não publicado)

BONATTO, F. S.; MIRON, L. I. G.; FORMOSO, C. T. Avaliação de empreendimentos habitacionais de interesse social com base na hierarquia de valor percebido pelo usuário. Ambiente Construído (Online), v. 11, p. 6783, 2011.

BONDUKI, N. G. Política habitacional e inclusão social no Brasil: revisão histórica e novas perspectivas no governo Lula. Revista Eletrônica de Arquitetura e Urbanismo, Rio de Janeiro, n. 1, p. 70-104, 2008. Disponível em: <http://www.usjt.br/arq.urb/numero_01/artigo_05_180908.pdf>. Acesso em: 01 nov. 2011.

BRANDÃO, D. Q. Disposições técnicas e diretrizes para projeto de habitações sociais evolutivas. Revista Ambiente Construído, Porto Alegre, v. 11, n. 2, p. 73-96, abr./jun. 2011.

BRASIL. Lei $\mathbf{n}^{\circ} \mathbf{1 0 . 2 5 7}$, de 10 de julho de 2001. Estatuto das Cidades.

Lei $\mathrm{n}^{\circ}$ 11.888, de 24 de dezembro de 2008. Lei da Assistência Técnica.

CHAHROUR, A. H., SOUDKI, K. A., STRAUBE, J. RBS polymer encased concrete wall part I: experimental study and theoretical provisions for flexure and shear. Construction and Building Materials, v.19, p. $550-563,2005$.

COMUNIDADE DA CONSTRUÇÃO. Alvenaria Estrutural com Blocos de Concreto - Passo a Passo. São Paulo, 2011.

Alvenaria Estrutural. São Paulo, 2012. Disponível em: <http://www.comunidadedaconstrucao.com.br/sistemas-construtivos/1/alvenariaestrutural/>. Acesso em: 09 jan. 2013. 
CONCÍLIO, V. P.; ABIKO, A. K. . Mutirão habitacional: adequação de processos e sistemas construtivos. São Paulo: Escola Politécnica, 1998 (Boletim Técnico do PCC).

CORSINI, R. Concreto e PVC para habitação popular: Perfis plásticos usados como fôrma para o concreto no preenchimento de paredes são alternativas para construção industrializada de moradias. Revista Infraestrutura Urbana. V. 4. Jun/Jul 2011.

EMPLASAGEO. Unidades de Informações Territorializadas - UIT's. Disponível em: <http://200.144.28.150/emplasa_geo/SiteHighRes/uit.asp>. Acesso em: 14 jan. 2013.

FABRICIO, M. M.; BAÍA, J. L.; MELHADO, S. B. Estudo da seqüência de etapas do projeto na construção de edifícios: cenário e perspectivas. In. Encontra Nacional de Engenharia de Produção - ENEGEP'98: A engenharia de produção e o futuro do trabalho. Anais(CD-ROM) UFF/ABEPRO, Niterói, 1998.

FERGUSON, B.; NAVARRETE, J. New approaches to progressive housing in Latin America: A key to habitat programs and policy. Habitat International, v. 27, p. 309-323, 2003.

FERRARI, T. S. "Concreto - PVC" - A Utilização do Sistema Royal para construção de casas populares. Seminário Habitação Econômica: Sistemas Industrializados à Base de Cimento para Habitação. Concrete Show South America 2011, São Paulo, Agosto 2011. Disponível em: <http://www.comunidadedaconstrucao.com.br/ativos/63/concrete-show-2011concreto-pvc-sistema-royal.html>. Acesso em: 03 nov, 2011.

FOLZ, R. R. Projeto Tecnológico para produção de habitação mínima e seu mobiliário. 2008. 371p. Tese (Doutorado em Arquitetura e Urbanismo) EESC/ Universidade de São Paulo.

FRANCO, L. S. Racionalização Construtiva, Inovação Tecnológica e Pesquisas. In: Curso de Formação em Mutirão. EPUSP, São Paulo, 1996.

FUNDAÇÃO JOÃO PINHEIRO. Centro de Estatística e Informações. Déficit habitacional no Brasil 2007. Ministério das Cidades, Secretaria Nacional de Habitação. Brasília, 2009. 129p.

FUndAÇÃO SEADE. Perfil Municipal. Fundação SEADE. São Paulo, 2012. Disponível em: <http://www.seade.gov.br/produtos/perfil/perfilMunEstado.php>. Acesso em: 14 jan. 2013. 
GAO, X.; ASAMI, Y. Preferential size of housing in Beijing. Habitat International, v. 35, n. 2, p. 206-213, 2011.

GONÇALVES, O. M., JOHN, V. M., PICCHI, F. A., SATO, N. M. Normas Técnicas para avaliação de sistemas construtivos inovadores. In: BONIN, C., ROMAN, H. (editores). Normalização e certificação na Construção Habitacional. Porto Alegre: ANTAC, 2003 (Coleção Habitare, v.3).

GRILO, L. M. et al. Implementação da gestão da qualidade em empresas de projeto. Revista Ambiente Construído. Associação Brasileira de Tecnologia no Ambiente Construído: Porto Alegre, v. 3, n. 1, p. 55-67, jan/mar 2003.

HOLANDA, É. P. T. Novas tecnologias construtivas para produção de vedações verticais: diretrizes para o treinamento da mão de obra. 2003. 174p. Dissertação (Mestrado em Engenharia). Universidade de São Paulo.

KELLETT, P.; FRANCO, F. Technology for social housing in Latin America. Habitat International, v. 17, n. 4, p. 47-58, 1993.

KISS, P. Você sabe o que é SINAT? Revista Téchne, Ed. 170, 2011.

LAWRENCE, R. Housing Quality: An Agenda for Research. Urban Studies, vl. 32, n. 10, p. 1655-1664, 1995.

LIMA, L. P.; FORMOSO, C. T.; ECHEVESTE, M. E. S. Proposta de um protocolo para 0 processamento de requisitos do cliente em empreendimentos habitacionais de interesse social (EHIS). Revista Ambiente Construído (Online), v. 11, p. 21-37, 2011.

LIMA, M. F. Provisão de HIS: benefícios da incorporação da flexibilidade ao projeto padrão e da participação do usuário final no processo de produção. 2008. Dissertação (Mestrado em Habitação) - Instituto de Pesquisas Tecnológicas, São Paulo, 2008.

LIU, A. M. M. Residential satisfaction in housing estates: a Hong Kong perspective. Automation in Construction, v. 8, n. 4, p. 511-524, 1999.

MALARD, M. L.; CONTI, A.; CAMPOMORI, M. J. L.; SOUZA, R. C. F. Avaliação pós-ocupação, participação de usuários e melhoria de qualidade de projetos habitacionais: uma abordagem fenomenológica. In: Alex Kenya Abiko; Sheila Walbe Ornstaein. (Org.). Inserção Urbana e Avaliação PósOcupação (APO) de Habitação de Interesse Social. 1 ed. Rio de Janeiro: FINEP, 2002, v. 1, p. 243-267. 
MARMOT, A. Flats Fit for Families: an Evaluation of Post Occupancy Evaluation. Design Studies, v. 4, n. 2, p. $92-99,1983$.

MARRA, L. Chuva isola São Luiz do Paraitinga (SP) e deixa quase toda população fora de casa. Folha Online. São Paulo, 02 Jan. 2010. Disponível em: <http://www1.folha.uol.com.br/folha/cotidiano/ult95u673855.shtml>.Acesso em: 08 nov, 2011.

MARROQUIM, F. M. G.; BARBIRATO, G. M. Flexibilidade Espacial em Projetos de Habitações de Interesse Social. In: IV Congresso Acadêmico da UFAL, 2007, Maceió. Anais... Maceió: Universidade Federal de Alagoas, 2007.

MARTUCCI, R.; BASSO, A. Uma visão integrada da análise e avaliação de conjuntos habitacionais; aspectos metodológicos da pós ocupação e do desempenho tecnológico. In: Alex Kenya Abiko; Sheila Walbe Ornstein. (Org.). Inserção urbana e avaliação pós ocupação (APO) da habitação de interesse social. 1 ed. São Paulo: FAUUSP-Coletânea Habitare, 2002, v. 1, p. 269-293.

MOHIT, M. A.; IBRAHIM, M.; RASHID, Y. R. Assessment of residential satisfaction in newly designed public low-cost housing in Kuala Lumpur, Malaysia. Habitat International, v. 34, n. 1, p. 18-27, 2010.

MORAES, O. B.; SANTANA, M. J. A. A satisfação do morador em habitações populares de Salvador: processo formal $\mathbf{x}$ informal. In: I Conferência LatinoAmericana de Construção Sustentável - $10^{\circ}$ Encontro Nacional de Tecnologia do Ambiente Construído, 2004, São Paulo. Construção Sustentável. São Paulo, 2004.

NAMUR, M. A questão da localização no processo de produção pública habitacional da CDHU no espaço urbano. Ambiente Construído, Porto Alegre, v. 4, n. 1, p. 55-66, jan./mar. 2004.

NOAL, E. B.; JANCZURA, R. A política nacional de habitação e a oferta de moradias. Textos \& Contextos. Porto Alegre. v. 10, n. 1, p. 157-169, jan.jjul. 2011

PALHARES, S. R. Variantes de modificação em habitação popular: do espaço planejado ao espaço vivido. 2001. Dissertação (Mestrado em Arquitetura) Escola de Arquitetura, Universidade Federal de Minas Gerais, Belo Horizonte, 2001. 
PARSEKIAN, G. A. (Org.). Parâmetros de projeto de alvenaria estrutural com blocos de concreto. Comunidade da Construção. 1. ed. São Carlos: EdUFSCar, 2012. $\quad$ v.1. $85 \quad$ p. $\quad$ Disponível em: http://www.comunidadedaconstrucao.com.br/upload/ativos/286/anexo/manualpar a.pdf. Acesso em: 30 jul. 2012.

PORTAL LAGOINHA. De Lagoinha para o mundo. Lagoinha, 2013. Disponível em: <http://www.portallagoinhasp.com.br/>. Acesso em: 06 jan. 2013.

PRUDÊNCIO JR., L. R.; OLIVEIRA, A. L. de; BEDIN, C. A. Alvenaria estrutural de blocos de concreto. Florianópolis: Associação Brasileira de Cimento Portland, 2002. $207 \mathrm{p}$.

REIS, A. T. L. Avaliação de Alterações Realizadas pelo Usuário no Projeto Original da Habitação Popular. In: ENCONTRO NACIONAL DE TECNOLOGIA DO AMBIENTE CONSTRUíDO, 6., 1995, Rio de Janeiro. Anais... Rio de Janeiro: ANTAC, 1995. v. 1, p. 319-324.

RHEINGANTZ, P. A.; AZEVEDO, G. A. N.; BRASILEIRO, A.; ALCANTARA, D.; QUEIROZ, M. Observando a Qualidade do Lugar: procedimentos para a avaliação pós-ocupação. 1. ed. Rio de Janeiro: Proarq/FAU-UFRJ, 2009. v. 1. $117 \mathrm{p}$.

ROMÉRO, M. A.; ORNSTEIN, S. W. Avaliação Pós Ocupação. Métodos e Técnicas Aplicados à Habitação Social. 1. ed. Porto Alegre: Coleção Habitare/FINEP/ANTAC, 2003. v. 1. 293 p.

ROYAL BUILDING TECHNOLOGIES. Royal Building Systems - Design Guide. 2006. Version 5.0: 21p.

Royal Building Systems - Technical Guide. 2006. Version 4.0: 20p.

SABBATINI, F. H. Desenvolvimento de métodos, processos e sistemas construtivos: formulação e aplicação de uma metodologia. $336 \mathrm{p}$. Tese (Doutorado) - Escola Politécnica, Universidade de São Paulo. São Paulo, 1989.

SACHT, H. M. Painéis de vedação de concreto moldados in loco: avaliação de desempenho térmico e desenvolvimento de concretos. 2008. Dissertação (Mestrado em Arquitetura e Urbanismo) - Escola de Engenharia de São Carlos da Universidade de São Paulo, São Carlos, 2008.

SALVADOR FILHO, J. A. A. Blocos de concreto para alvenaria em construções industrializadas. 2007. Tese (Doutorado em Engenharia de Estruturas) - Escola de Engenharia de São Carlos da Universidade de São Paulo, São Carlos, 2007. 
SILVA, P. M. Gerenciamento de Obras Construídas por Mutirão: Estudos de Caso de Empreendimentos no Vale do Paraíba - SP. 2013. Dissertação (Mestrado em Engenharia Civil) - Escola Politécnica, Universidade de São Paulo, São Paulo, 2012.

SILVESTRE, M. G.; CARDOSO, L. R. A. Assistência técnica para melhoria habitacional. In: Congresso Luso-Brasileiro para o Planejamento Urbano, Regional, Integrado e Sustentável, 5., 2012, Brasília. Anais... Brasília: Universidade de Brasília, 2012a.

SILVESTRE, M. G.; CARDOSO, L. R. A. Influência dos sistemas construtivos nas modificações promovidas pelo usuário em empreendimentos de HIS. In: Encontro Nacional de Tecnologia do Ambiente Construído, 14., 2012, Juiz de Fora. Anais... Juiz de Fora: Universidade Federal de Juiz de Fora, 2012b.

TILL, J.; SCHNEIDER, T. Flexible housing: the means to the end. Architectural Research Quarterly, v. 9, n. 3-4, p. 287-296, 2005.

TONUSSI, A. M. S. Release. Site Oficial do Município de Cunha. Disponível em: http://www.cunha.sp.gov.br. Acesso em: 19.12.2012

TRANI, E.; SOUZA, M. C. P.; RUDGE, M. S.; MORO, M. F. L. B., ROSSI, T. B.; DENIZO, V. Panorama da habitação de interesse social. Governo do Estado de São Paulo. Secretaria da Habitação / CDHU. São Paulo, 2008.

VAN GELDER, J. L. Feeling and thinking: quantifying the relationship between perceived tenure security and housing improvement in an informal neighborhood in Buenos Aires. Habitat International, v. 31, p. 219-231, 2007.

VILLA, S. B. Avaliando a habitação: relações entre qualidade, projeto e avaliação pós-ocupação em apartamentos. Revista Ambiente Construído, v. 9, n. 2, p. 119-138, 2009.

WERNA, E.; ABIKO, A. K. COELHO, L. O.; SIMAS, R.; KEIVANI, R.; HAMBURGUER, D. S.; ALMEIDA, M..A. P. Pluralismo na Habitação. São Paulo: Annablume - FINEP, 2001. 300 p. 


\section{APÊNDICE A - Diretrizes e roteiro para entrevistas em campo}

\section{DIRETRIZES E ROTEIRO BÁSICO PARA ENTREVISTAS EM CAMPO}

\section{MÉTODOS UTILIZADOS}

\section{Entrevista estruturada}

- Roteiro técnico (formulário)

- Registros em áudio

2. Walkthrough: consiste em uma caminhada pelos ambientes em análise, onde o pesquisador conversa com os usuários e analisa suas reações em relação ao ambiente, complementando as informações com fotografias, croquis gerais e gravações de áudio e de vídeo.

- Roteiro técnico (formulário)

- Registros fotográficos

- Registros em vídeo

- Registros em áudio

\section{ROTEIRO DE VISITA TÉCNICA}

1. Apresentação - o entrevistador/ técnico deve se apresentar ao morador e explicar as características e objetivos da visita:

a. Apresentação individual de cada entrevistador*;

b. Pesquisa científica visando obter informações sobre conjuntos habitacionais para melhorar os programas de provisão habitacional;

c. Garantia de sigilo das informações: os dados serão tratados em conjunto e não serão publicados endereços e identificação individual de cada morador ou família;

2. Entrevista: realizar a entrevista com o morador (itens I a IV do formulário de visita). Se possível e se o morador aceitar, gravar o áudio da entrevista.

3. Avaliação: visitar todos os cômodos da casa e fazer uma avaliação do imóvel (itens V a VII do formulário de visita).

4. Imagens: registrar a visita através de imagens (fotos e/ ou vídeos). Essa etapa pode ser realizada durante a avaliação ou depois.

5. Agradecimento e despedida: agradecer ao morador e fornecer contatos.

Deve-se tentar realizar a entrevista e visita no menor tempo possível para não atrapalhar a rotina da família.

* O ideal é ter um profissional da prefeitura ou CDHU junto com o técnico. É recomendável que os entrevistadores usem crachás de identificação para facilitar a recepção por parte do morador. 


\section{APÊNDICE B - Formulário de caracterização dos empreendimentos}

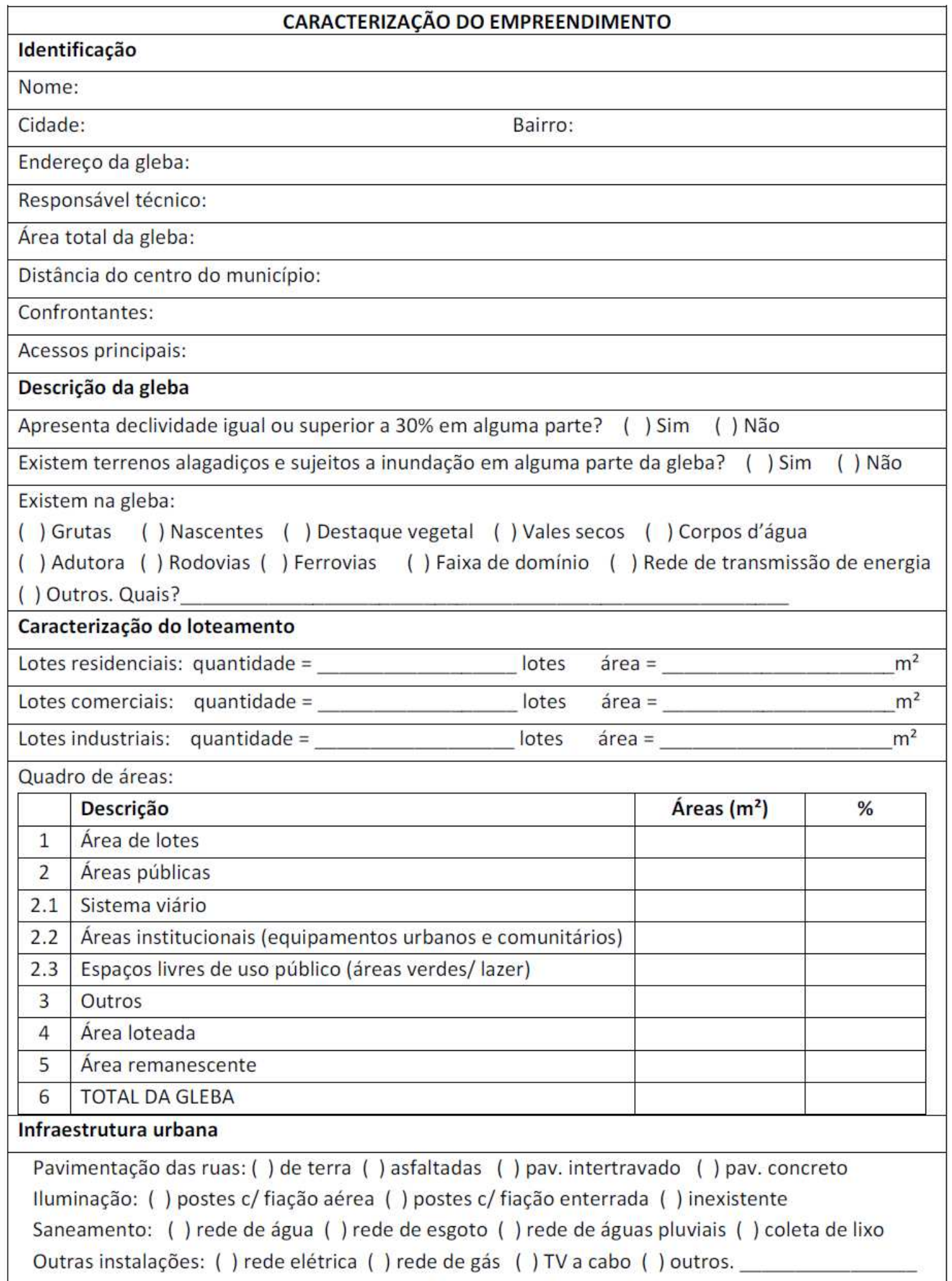




\section{Equipamentos urbanos e espaços públicos (citar quantidade)}

( ) escola ( ) posto de saúde ( ) praça

( ) parque ( ) playground ( ) quadra ( ) outros.

Lotes

Quantidade:

\section{Unidades habitacionais}

Tipologias:

\begin{tabular}{|l|l|l|l|}
\hline Quantidade: & & Área (faixa): & \\
\hline Área total: & & Área construída: & \\
\hline
\end{tabular}

Caracterização dos cômodos:

\begin{tabular}{|l|l|l|l|}
\hline \multicolumn{1}{|c|}{ Cômodo } & Quant. & Área $\left(\mathrm{m}^{\mathbf{2}}\right)$ & Dimensões \\
\hline Sala & & & \\
\hline Sala de jantar & & & \\
\hline Copa & & & \\
\hline Cozinha & & & \\
\hline Área de serviço & & & \\
\hline Despensa & & & \\
\hline Dormitório & & & \\
\hline Suíte & & & \\
\hline Banheiro (incl. suíte) & & & \\
\hline Varanda & & & \\
\hline Edícula & & & \\
\hline Garagem & & & \\
\hline Como & & & \\
\hline
\end{tabular}

Como se deu a escolha do (s) sistema (s) construtivo (s)?

Houve algum estudo comparativo dos sistemas construtivos disponíveis?

Quais os critérios adotados para determinação do (s) sistema (s) construtivo (s)? 
Descrição dos imóveis conforme os dez órgãos básicos do edifício:

Terrapleno:

Fundação:

Estrutura:

Cobertura:

Vedação:

Vãos:

Paramentos:

Pisos:

Instalações:

Infraestrutura:

Equip. urbanos: 


\section{Histórico do empreendimento}

Qual o cenário antes da execução do empreendimento?

Déficit municipal:

unidades

Qual o cenário habitacional do município hoje?

Déficit municipal:

unidades

Por que foi executado o empreendimento?

Tempo de concepção:

Tempo de projeto:

Tempo de execução:

Como foi a etapa de concepção do empreendimento? Quem participou? Quais as dificuldades encontradas?

Como foi a etapa de projeto? Quem participou? Quais as dificuldades encontradas?

Como foi a etapa de execução? Quem participou? Quais as dificuldades encontradas? 
Como foi a etapa de entrega? Quem participou? Quais as dificuldades encontradas?

Como foi o pós-obra/ entrega? Quem participou? Quais as dificuldades encontradas? Foi entregue manual do usuário? (se sim, há como disponibilizar esse material?)

Qual o custo por unidade habitacional? reais

Qual o custo total do emprendimento? reais

Os moradores pagaram ou pagam pelas casas? Se sim, quanto e como?

Outras informações relevantes:

Anexar todos os documentos possíveis:

- projetos (implantação, unidades habitacionais, equipamentos urbanos etc.);

- quantitativos e orçamentos;

- memoriais descritivos;

- manual do usuário;

- diário de obra;

- reportagens, vídeos e outras formas de mídia;

- fotos e vídeos das fases de obra, entrega e pós-obra;

- outros. 


\section{APÊNDICE C - Formulário de visita e entrevista com moradores}

O formulário a seguir foi utilizado para a coleta de informações durante as visitas às residências e contempla tanto a etapa de entrevista com os moradores quanto a fase de avaliação técnica através da técnica de Walkthrough.

A versão apresentada aqui é a que foi utilizada para o empreendimento São Luiz do Paraitinga "C", sendo que a única diferença entre esta versão e as versões utilizadas para os demais empreendimentos é a planta utilizada nas etapas VI, de registro das modificações realizadas e proposta de novas modificações. 
FICHA DE VISITA E ENTREVISTA COM MORADORES

Empreendimento

Endereço

Nome do Entrevistado

Entrevistadores

Data da entrevista

\begin{tabular}{|c|c|}
\hline Entrevistadores & \\
\hline & $/ 20$ \\
\hline & $/ 20$ \\
\hline
\end{tabular}

\section{I - Caracterização da família}

1. Quantas pessoas moram na casa?

2. Como é a composição da família? (Indicar a quantidade, com relação ao chefe da família)

$\begin{array}{llll}\text { ( ) Marido } & \text { ( ) Neto } & \text { ( ) Genro } & \text { ( ) Cunhado ( ) Cunhada } \\ \text { ( ) Esposa } & \text { ( ) Neta } & \text { ( ) Nora } & \text { ( ) Outros. Quais? } \\ \text { ( ) Filho } & \text { ( ) Pai } & \text { ( ) Irmăo } & \\ \text { ( ) Filha } & \text { ( ) Mãe } & \text { ( ) Irmã } & \end{array}$

3. Quais dos seguintes bens sua família possui? (Múltipla escolha)
$\square$ Geladeira
$\square$ Aparelho de som
$\square$ Chuveiro elétrico
$\square$ Computador
$\square$ Vídeo cassete/DVD
$\square$ Máquina de lavar roupas
$\square$ Fogăo
$\square$ Telefone fixo
$\square$ Televisão
$\square$ Ferro elétrico
$\square$ Forno microondas
$\square$ Empregada mensalista
$\square$ Freezer
$\square$ Carro
$\square$ Telefone celular
$\square$ Moto

\section{II - Caracterização do imóvel}

\section{Qual é a situação da casa?}

$\square$ Própria (quitada) $\square$ Própria (financiada) $\square$ Alugada $\square$ Cedida $\square$ Outra. Qual?

2. Está morando na casa desde a entrega? $\square \operatorname{Sim} \square$ Não. Há quanto tempo?

3. Qual a área do lote?

$\mathrm{m}^{2} \quad$ 4. Qual a área da casa?

$\mathrm{m}^{2}$

5. Caracterização dos cômodos:

\begin{tabular}{|l|l|l|l|l|l|}
\hline \multicolumn{1}{|c|}{ Cômodo } & Quant. & $\begin{array}{c}\text { Modificado? } \\
(\mathbf{S} / \mathbf{N})\end{array}$ & Dimensões & $\begin{array}{c}\text { Area } \\
\left(\mathrm{m}^{2}\right)\end{array}$ & $\begin{array}{c}\text { O cômodo é } \\
\text { adequado? (S/ N) }\end{array}$ \\
\hline Sala & & & & & \\
\hline Sala de jantar & & & & & \\
\hline Copa & & & & & \\
\hline Cozinha & & & & & \\
\hline Área de serviço & & & & & \\
\hline Despensa & & & & & \\
\hline Dormitório & & & & & \\
\hline Suíte & & & & & \\
\hline Banheiro (incl. suite) & & & & & \\
\hline Varanda & & & & & \\
\hline Edícula & & & & & \\
\hline Garagem & & & & & \\
\hline
\end{tabular}




\begin{tabular}{|c|c|}
\hline III - Habitabilidade e Patologias & \\
\hline 1. A casa tem problemas com umidade, infiltrações e mofo? & $\square \operatorname{Sim} \quad \square$ Não \\
\hline 1.1. Se respondeu sim. Onde está o problema? & $\square$ Próximo ao teto / laje $\square$ Piso \\
\hline 2. Em sua casa, há necessidade de acender as lâmpadas : & \\
\hline$\square$ Durante o dia e a noite $\square$ Somente durante a & oite \\
\hline 3. Você considera a iluminação de sua casa: (1) Ótima (2) Boa (3 & Regular (4) Ruim (5) Não tem o cômodo \\
\hline ( ) sala ( ) cozinha ( ) área de serviço ( ) dormitórios ( ) ba & nheiros ( ) outros.Quais? \\
\hline 4. Você considera a ventilação de sua casa: (1) Ótima (2) Boa (3) & Regular (4) Ruim (5) Năo tem o cômodo \\
\hline ( ) sala ( ) cozinha ( ) área de serviço ( ) dormitórios ( ) ba & nheiros ( ) outros.Quais? \\
\hline 5. Observou problemas construtivos/ patologias na casa? & $\square \operatorname{Sim}$ \\
\hline 5.1. Se respondeu sim, qual e quanto tempo após a e & ntrega? (descrever) \\
\hline
\end{tabular}

IV - Realização de modificações no imóvel

1. Você considera que a casa foi entregue completa? $\square \operatorname{Sim} \square$ Não

2. Você considera que a casa atende a todas as necessidades da família? $\square$ Sim $\square$ Não 2.1. Se respondeu não, por quê? (descrever)

3. Já fez alguma modificação (reforma) nessa casa? $\square \operatorname{Sim} \quad \square$ Não

Se respondeu sim:

3.1. Utilizou algum projeto para realização da reforma/ ampliação?

$\square$ Sim, projeto próprio ou feito por parente/ amigo COM formação técnica

$\square$ Sim, projeto próprio ou feito por parente/ amigo SEM formação técnica

$\square$ Sim, projeto fornecido pela prefeitura/ CDHU $\square$ Sim, projeto contratado $\square$ Não

Se respondeu sim:

3.1.1. A modificação (reforma) foi feita de acordo com o projeto?

$\square \operatorname{Sim} \quad \square$ Parcialmente $\quad \square$ Não

Se respondeu não:

3.1.2. Se fosse fornecido um projeto, seguiria mesmo que fosse diferente do que desejava?

$\square$ Não $\square$ Sim, mas fazendo alterações por conta própria

$\square$ Sim, mas procuraria ajuda técnica para fazer alterações

$\square$ Sim, sem fazer alterações 


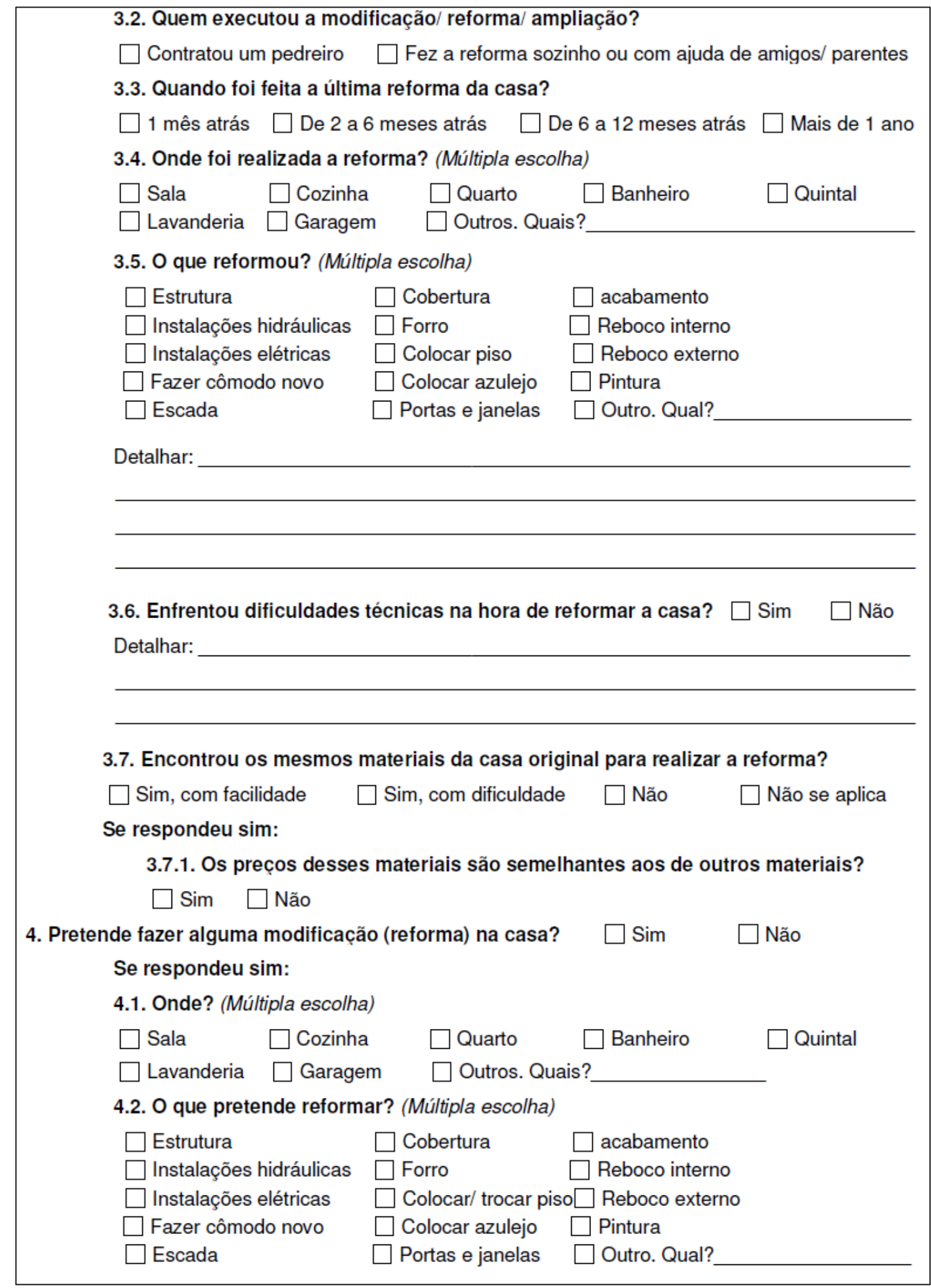


Detalhar:

4.3. Você acha que a modificação (reforma) da casa é urgente? $\square \operatorname{Sim} \square$ Não 4.4. Qual o benefício das modificações (realizadas/ intencionadas) para a família?

$\square$ Ampliar a casa

Melhorar condições da saúde da família

$\square$ Outros. Quais? $\square$ Melhorar a aparência da construção

$\square$ Valorizar o imóvel

V - Avaliação técnica do imóvel (deve ser preenchido pelo técnico)

1. Qual o processo construtivo utilizado? (Múltipla escolha)

$\square$ Alvenaria estrutural $\square$ Parede de concreto $\square$ Concreto PVC $\square$ Outro. Qual?

2. Avaliação do imóvel conforme os dez órgãos básicos do edifício:

Terrapleno:

Fundação:

Estrutura:

Cobertura:

Vedação:

Vãos:

Paramentos:

Pisos:

Instalações:

Infraestrutura: 


\section{Observou problemas construtivos/ patologias na casa? $\square \operatorname{Sim} \quad \square$ Não} 3.1. Se respondeu sim, descreva.

\section{A ventilação é adequada? $\square \operatorname{Sim} \square$ Não}

Comente:

\section{A iluminação é adequada? $\square \operatorname{Sim} \square$ Não}

Comente:

6. A casa tem problemas com umidade, infiltração ou mofo? $\square \operatorname{Sim} \quad \square$ Não

$$
\text { 6.1 Se respondeu sim. Onde está o problema? } \square \text { Próximo ao teto/laje } \square \text { Piso }
$$

7. Avaliação dos cômodos:

\begin{tabular}{|c|c|c|c|c|c|}
\hline Cômodo & Quant. & Ventilação & Iluminaçāo & Patologias & $\begin{array}{c}\dot{\mathbf{E}} \\
\text { adequado? }\end{array}$ \\
\hline Sala & & & & & \\
\hline Sala de jantar & & & & & \\
\hline Copa & & & & & \\
\hline Cozinha & & & & & \\
\hline Área de serviço & & & & & \\
\hline Despensa & & & & & \\
\hline Dormitório & & & & & \\
\hline Suíte & & & & & \\
\hline Banheiro (incl. suíte & & & & & \\
\hline Varanda & & & & & \\
\hline Edícula & & & & & \\
\hline Garagem & & & & & \\
\hline
\end{tabular}

Notas: (1) Ótimo (2) Bom (3) Regular (4) Ruim (5) Não tem o cômodo
8. A casa entregue atende a todas as necessidades da família?

\subsection{Se respondeu não, por quê? (descrever)}


9. A casa sofreu alguma modificação em relação ao projeto original? $\square \operatorname{Sim} \quad \square$ Não Se respondeu sim:

9.1 As modificações representam risco à estrutura do imóvel? $\square \operatorname{Sim} \quad \square$ Não Explique:

9.2 As modificações representam risco à funcionalidade e durabilidade do imóvel?

$\square \operatorname{Sim} \square$ Não

Explique:

9.3. Foram utilizados os mesmos materiais da casa original?

Sim, totalmente $\square$ Sim, parcialmente $\square$ Não

Detalhar:

9.4. O resultado das modificações foi:

$\square$ Muito bom $\square$ Bom $\square$ Razoável $\square$ Ruim $\square$ Péssimo

9.5. Comentários:

10. Em sua opinião, são necessárias modificações? $\square$ Sim $\square$ Não

10.1. Se respondeu sim, quais modificações são necessárias e por quê? (descrever)

10.2. É possível fazer essas modificações utilizando o processo construtivo original?

Informações adicionais: 


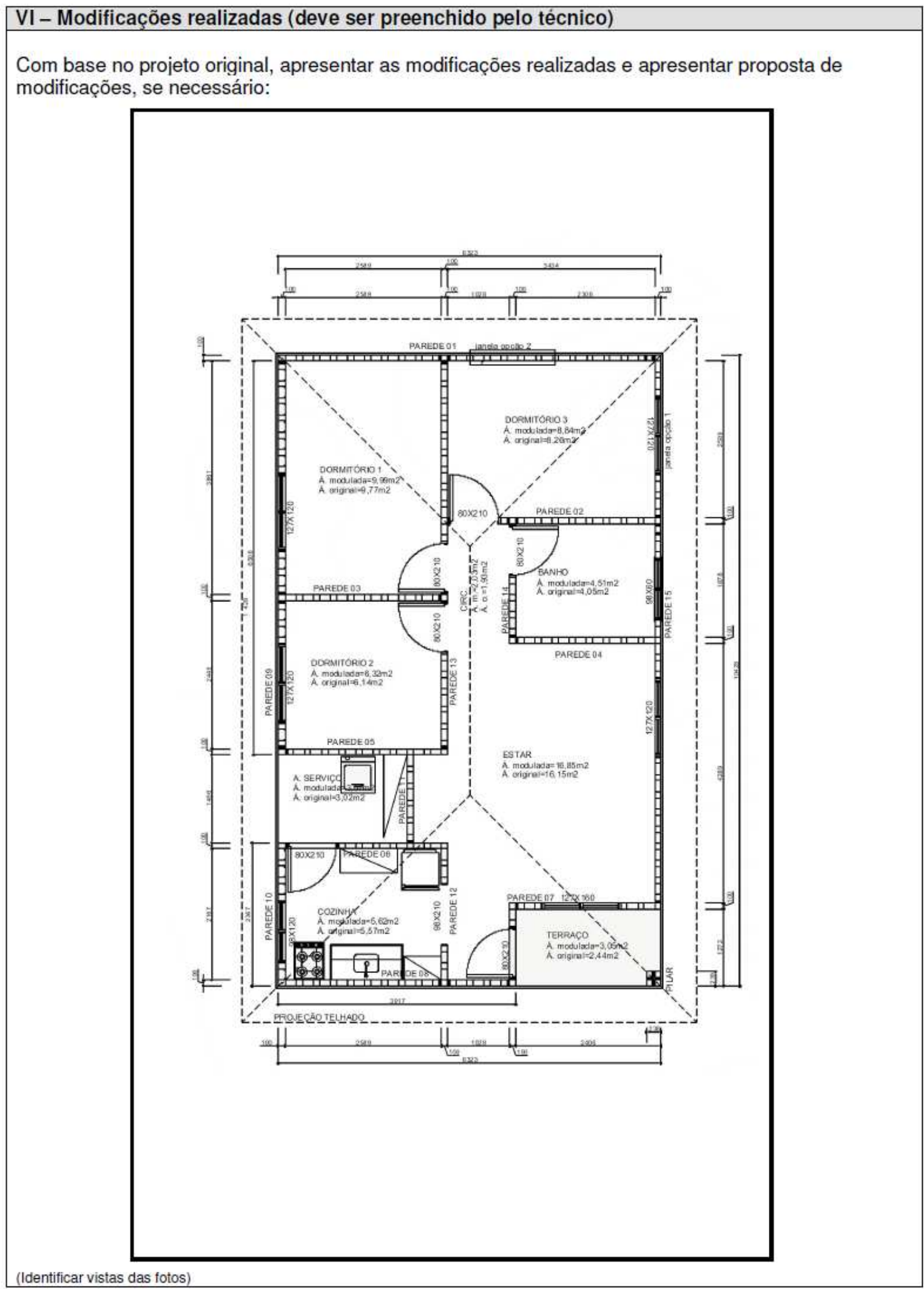




\section{ANEXO A - Quadro resumo do perfil dos municípios visitados}

\begin{tabular}{|c|c|c|c|c|c|}
\hline Perfil Municipal & & S. L. Paraitinga & Cunha & Lagoinha & Estado \\
\hline Região Administrativa & & $\begin{array}{c}\text { São José dos } \\
\text { Campos }\end{array}$ & $\begin{array}{c}\text { São José dos } \\
\text { Campos }\end{array}$ & $\begin{array}{c}\text { São José dos } \\
\text { Campos }\end{array}$ & \\
\hline Região de Governo & & Taubaté & Guaratinguetá & Taubaté & \\
\hline Aniversário & & 8 de maio & 20 de abril & 23 de dezembro & \\
\hline Santo Padroeiro & & São Luiz de Tolosa & $\begin{array}{c}\text { Nossa Senhora da } \\
\text { Imaculada } \\
\text { Conceição }\end{array}$ & $\begin{array}{c}\text { Nossa Senhora da } \\
\text { Conceição }\end{array}$ & \\
\hline Prefeito & 2013 & $\begin{array}{l}\text { Alex Euzébio } \\
\text { Torres - PR }\end{array}$ & \begin{tabular}{|l|} 
Osmar Felipe \\
Júnior-PSDB \\
\end{tabular} & $\begin{array}{c}\text { Jose Galvao da } \\
\text { Rocha - PSDB }\end{array}$ & \\
\hline Presidência da Câmara & 2013 & $\begin{array}{c}\text { Nivaldo } \\
\text { Alessandro de } \\
\text { Medeiros - PR }\end{array}$ & $\begin{array}{l}\text { Haroldo Ronaldo } \\
\text { Fernandes - PTB }\end{array}$ & $\begin{array}{c}\text { Antonio de Paula } \\
\text { (Tijolo) - PSDB }\end{array}$ & \\
\hline
\end{tabular}

\begin{tabular}{|l|c|c|c|c|c|}
\hline Território e População & Ano & S. L. Paraitinga & Cunha & Lagoinha & Estado \\
\hline Área & 2012 & 617,15 & $1.407,17$ & 255,92 & $248.209,43$ \\
\hline População & 2012 & 10.427 & 21.804 & 4.833 & 41.939 .997 \\
\hline Densidade Demográfica (Habitantes/km2) & 2012 & 16,9 & 15,49 & 18,88 & 168,97 \\
\hline $\begin{array}{l}\text { Taxa Geométrica de Crescimento Anual da } \\
\text { População - 2010/2012 (Em \% a.a.) }\end{array}$ & 2012 & 0,14 & $-0,16$ & $-0,09$ & 0,87 \\
\hline Grau de Urbanização (Em \%) & 2010 & 59,44 & 55,65 & 64,83 & 95,94 \\
\hline
\end{tabular}

\begin{tabular}{|c|c|c|c|c|c|}
\hline Estatisticas Vitais e Saúde & Ano & S. L. Paraitinga & Cunha & Lagoinha & Estado \\
\hline Taxa de Natalidade (Por mil habitantes) & 2011 & 10,56 & 10,58 & 9,51 & 14,68 \\
\hline Taxa de Mortalidade Infantil (Por mil nascidos vivos) & 2011 & 9,09 & 4,33 & 43,48 & 11,55 \\
\hline $\begin{array}{l}\text { Taxa de Mortalidade da População entre } 15 \text { e } 34 \\
\text { Anos (Por cem mil habitantes nessa faixa etária) }\end{array}$ & 2010 & 124,84 & 174,14 & 69,74 & 117,98 \\
\hline Mães Adolescentes (< 18 anos) (Em \%) & 2010 & 8,21 & 8,39 & 15,22 & 6,96 \\
\hline Condições de Vida & Ano & S. L. Paraitinga & Cunha & Lagoinha & Estado \\
\hline $\begin{array}{l}\text { Indice Paulista de Responsabilidade Social - IPRS - } \\
\text { Dimensão Riqueza }\end{array}$ & 2008 & 29 & 21 & 20 & 58 \\
\hline $\begin{array}{l}\text { Índice Paulista de Responsabilidade Social - IPRS - } \\
\text { Dimensão Longevidade }\end{array}$ & 2008 & 84 & 64 & 67 & 73 \\
\hline $\begin{array}{l}\text { Índice Paulista de Responsabilidade Social - IPRS - } \\
\text { Dimensão Escolaridade }\end{array}$ & 2008 & 66 & 45 & 75 & 68 \\
\hline Índice Paulista de Responsabilidade Social - IPRS & 2008 & $\begin{array}{c}\text { Grupo } 4 \text { - Baixos } \\
\text { níveis de riqueza } \\
\text { e nível } \\
\text { intermediário de } \\
\text { longevidade e/ou } \\
\text { escolaridade }\end{array}$ & $\begin{array}{c}\text { Grupo } 5 \text { - } \\
\text { Municípios mais } \\
\text { desfavorecidos, } \\
\text { tanto em riqueza } \\
\text { como nos } \\
\text { indicadores } \\
\text { sociais } \\
\end{array}$ & $\begin{array}{c}\text { Grupo } 4 \text { - Baixos } \\
\text { niveis de riqueza } \\
\text { e nível } \\
\text { intermediário de } \\
\text { longevidade e/ou } \\
\text { escolaridade }\end{array}$ & \\
\hline Índice de Desenvolvimento Humano - IDH & 2000 & 0,754 & 0,733 & 0,752 & 0,814 \\
\hline Renda per Capita (Em salários mínimos) & 2000 & 1,57 & 1 & 1,21 & 2,92 \\
\hline $\begin{array}{l}\text { Domicílios com Renda per Capita até } 1 / 4 \text { do Salário } \\
\text { Mínimo (Em \%) }\end{array}$ & 2000 & 5,25 & 14,05 & 8,43 & 5,16 \\
\hline $\begin{array}{l}\text { Domicílios com Renda per Capita até } 1 / 2 \text { do Salário } \\
\text { Mínimo (Em \%) }\end{array}$ & 2000 & 19,94 & 34,66 & 28,45 & 11,19 \\
\hline Educação & Ano & S. L. Paraitinga & Cunha & Lagoinha & Estado \\
\hline $\begin{array}{l}\text { Taxa de Analfabetismo da População de } 15 \text { Anos e } \\
\text { Mais (Em \%) }\end{array}$ & 2000 & 15,63 & 14,15 & 14,36 & 6,64 \\
\hline $\begin{array}{l}\text { Média de Anos de Estudos da População de } 15 \text { a } 64 \\
\text { Anos }\end{array}$ & 2000 & 5,33 & 5,14 & 5,48 & 7,64 \\
\hline $\begin{array}{l}\text { População de } 25 \text { Anos e Mais com Menos de } 8 \text { Anos } \\
\text { de Estudo (Em \%) }\end{array}$ & 2000 & 79,12 & 82,53 & 82,15 & 55,55 \\
\hline $\begin{array}{l}\text { População de } 18 \text { a } 24 \text { Anos com Ensino Médio } \\
\text { Completo (Em \%) }\end{array}$ & 2000 & 18,37 & 15,33 & 30,96 & 41,88 \\
\hline
\end{tabular}




\begin{tabular}{|c|c|c|c|c|c|}
\hline Habitação e Infraestrutura Urbana & Ano & S. L. Paraitinga & Cunha & Lagoinha & Estado \\
\hline Domicílios com Espaço Suficiente (Em \%) & 2000 & 86,8 & 89,4 & 91,92 & 83,16 \\
\hline $\begin{array}{l}\text { Domicilios com Infraestrutura Interna Urbana } \\
\text { Adequada }(\mathrm{Em} \%)\end{array}$ & 2000 & 76 & 86,44 & 82,19 & 89,29 \\
\hline Coleta de Lixo - Nivel de Atendimento ( $\mathrm{Em} \%$ ) & 2010 & 99,8 & 98,28 & 99,35 & 99,66 \\
\hline $\begin{array}{l}\text { Abastecimento de Água - Nivel de Atendimento (Em } \\
\% \text { \%) }\end{array}$ & 2010 & 96,6 & 98,33 & 98,71 & 97,91 \\
\hline Esgoto Sanitário - Nivel de Atendimento (Em \%) & 2010 & 83,84 & 90,02 & 94,55 & 89,75 \\
\hline Existência de Áreas de Risco com Moradias & 2003 & Não & Sim & Sim & Sim \\
\hline Número de Áreas de Risco Ocupadas por Moradias & 2003 & - & 2 & 6 & ... \\
\hline Existência de Favelas & 2003 & Não & Não & Não & Sim \\
\hline Existência de Cortiços & 2003 & Näo & Não & Não & Sim \\
\hline
\end{tabular}

\begin{tabular}{|c|c|c|c|c|c|}
\hline Emprego e Rendimento & Ano & S. L. Paraitinga & Cunha & Lagoinha & Estado \\
\hline $\begin{array}{l}\text { Participação dos Empregos Formais da Agricultura, } \\
\text { Pecuária, Produção Florestal, Pesca e Aquicultura no } \\
\text { Total de Empregos Formais (Em \%) }\end{array}$ & 2011 & 22,1 & 30,7 & 20,6 & 2,7 \\
\hline $\begin{array}{l}\text { Participação dos Empregos Formais da Indústria no } \\
\text { Total de Empregos Formais (Em \%) }\end{array}$ & 2011 & 7,3 & 5,9 & 3,4 & 20,9 \\
\hline $\begin{array}{l}\text { Participação dos Empregos Formais da Construção } \\
\text { no Total de Empregos Formais (Em \%) }\end{array}$ & 2011 & 0,3 & 0,9 & - & 5,5 \\
\hline $\begin{array}{l}\text { Participação dos Empregos Formais do Comércio } \\
\text { Atacadista e Varejista e do Comércio e Reparação de } \\
\text { Veículos Automotores e Motocicletas no Total de } \\
\text { Empregos Formais (Em \%) }\end{array}$ & 2011 & 19,7 & 17,8 & 19,6 & 19,3 \\
\hline $\begin{array}{l}\text { Participação dos Empregos Formais dos Serviços no } \\
\text { Total de Empregos Formais (Em \%) }\end{array}$ & 2011 & 50,6 & 44,7 & 56,5 & 51,6 \\
\hline $\begin{array}{l}\text { Rendimento Médio dos Empregos Formais da } \\
\text { Agricultura, Pecuária, Produção Florestal, Pesca e } \\
\text { Aquicultura (Em reais correntes) }\end{array}$ & 2011 & 905,47 & 751,03 & 724,63 & $1.234,37$ \\
\hline $\begin{array}{l}\text { Rendimento Médio dos Empregos Formais da } \\
\text { Indústria (Em reais correntes) }\end{array}$ & 2011 & 1759,94 & 1095,11 & $x$ & $2.548,90$ \\
\hline $\begin{array}{l}\text { Rendimento Médio dos Empregos Formais da } \\
\text { Construção (Em reais correntes) }\end{array}$ & 2011 & $x$ & $x$ & - & $1.903,48$ \\
\hline $\begin{array}{l}\text { Rendimento Médio dos Empregos Formais do } \\
\text { Comércio Atacadista e Varejista e do Comércio e } \\
\text { Reparação de Veículos Automotores e Motocicletas } \\
\text { (Em reais correntes) }\end{array}$ & 2011 & 998,7 & 953,01 & 936,63 & $1.590,37$ \\
\hline $\begin{array}{l}\text { Rendimento Médio dos Empregos formais dos } \\
\text { Serviços (Em reais correntes) }\end{array}$ & 2011 & 1620,35 & 1309,22 & 1372,7 & $2.309,60$ \\
\hline $\begin{array}{l}\text { Rendimento Médio do Total de Empregos Formais } \\
\text { (Em reais correntes) }\end{array}$ & 2011 & 1346,06 & 1058,45 & 1151,51 & $2.170,16$ \\
\hline Economia & Ano & S. L. Paraitinga & Cunha & Lagoinha & Estado \\
\hline PIB (Em milhões de reais correntes) & 2010 & 89,49 & 140,42 & 51,48 & $1.247 .595,93$ \\
\hline PIB per Capita (Em reais correntes) & 2010 & 8607,15 & 6418,86 & $10.631,63$ & $30.264,06$ \\
\hline Participação no PIB do Estado (Em \%) & 2010 & 0,01 & 0,01 & 0 & 100,00 \\
\hline $\begin{array}{l}\text { Participação da Agropecuária no Total do Valor } \\
\text { Adicionado (Em \%) }\end{array}$ & 2010 & 13,6 & 13,45 & 18,91 & 1,87 \\
\hline $\begin{array}{l}\text { Participação da Indústria no Total do Valor } \\
\text { Adicionado (Em \%) }\end{array}$ & 2010 & 12,95 & 11,67 & 20,55 & 29,08 \\
\hline $\begin{array}{l}\text { Participação dos Serviços no Total do Valor } \\
\text { Adicionado (Em \%) }\end{array}$ & 2010 & 73,45 & 74,88 & 60,53 & 69,05 \\
\hline Participação nas Exportações do Estado (Em \%) & 2011 & - & 0,000159 & - & 100,00 \\
\hline
\end{tabular}

Fonte: SEADE - Fundação Sistema Estadual de Análise de Dados, 2013.

\begin{tabular}{|c|l|l|l|}
\hline \multicolumn{4}{|c|}{ Convençōes Utilizadas } \\
\hline X. & Dado năo disponivel & - & Fenômeno inexistente \\
\hline $\mathrm{P}$ & Dado sigiloso & 0 & $\begin{array}{l}\text { Năo foi atingida a } \\
\text { unidade adotada }\end{array}$ \\
\hline z & Dado preliminar & e & Dado estimado \\
\hline
\end{tabular}

